\title{
The Origins of WEIRD Psychology
}

\author{
Jonathan Schulz, ${ }^{1 *}$ Duman Bahrami-Rad, ${ }^{2}$ Jonathan Beauchamp, ${ }^{3}$ and Joseph Henrich ${ }^{4 *}$ \\ ${ }^{1}$ Department of Human Evolutionary Biology, Harvard University. \\ ${ }^{2}$ Department of Economics, Simon Fraser University. \\ ${ }^{3}$ Department of Economics, University of Toronto. \\ ${ }^{4}$ Department of Human Evolutionary Biology, Harvard University, and CIFAR.
}

*Correspondence to: jonathan.schulz77@gmail.com and joseph.henrich@gmail.com

June 22, 2018

\begin{abstract}
Recent research not only confirms the existence of substantial psychological variation around the globe but also highlights the peculiarity of populations that are Western, Educated, Industrialized, Rich and Democratic (WEIRD). We propose that much of this variation arose as people psychologically adapted to differing kin-based institutions - the set of social norms governing descent, marriage, residence and related domains. We further propose that part of the variation in these institutions arose historically from the Catholic Church's marriage and family policies, which contributed to the dissolution of Europe's traditional kin-based institutions, leading eventually to the predominance of nuclear families and impersonal institutions. By combining data on 20 psychological outcomes with historical measures of both kinship and Church exposure, we find support for these ideas in a comprehensive array of analyses across countries, among European regions and between individuals with different cultural backgrounds.
\end{abstract}


A growing body of research suggests that populations around the globe vary substantially along several important psychological dimensions, and that people from societies characterized as Western, Educated, Industrialized, Rich and Democratic (WEIRD) are particularly unusual (1-6). Often at the extremes of global distributions, people from WEIRD populations tend to be more individualistic, independent, analytically-minded and impersonally prosocial (e.g., trusting strangers) while revealing less conformity, obedience, in-group loyalty and nepotism $(3,5-13)$. While these patterns are now well documented, efforts to explain this variation from a cultural evolutionary and historical perspective have just begun (13-20). Here, we develop and test a cultural evolutionary theory that aims to explain a substantial portion of this psychological variation, both within and across nations. Not only does our approach contribute to explaining global variation and address why WEIRD societies so often occupy the tail ends of global distributions, but it also helps explain the psychological variation within Europe-among countries, across regions within countries and between individuals with different cultural backgrounds within the same country and region.

Our approach integrates three insights. The first, drawing on anthropology, reveals that the institutions built around kinship and marriage vary greatly across societies (21-23) and that much of this variation developed as societies scaled up in size and complexity, especially after the origins of food production 12,000 years ago $(22,24-29)$. In forging the tightly-knit communities needed to defend agricultural fields and pastures, cultural evolution gradually wove together social norms governing marriage, post-marital residence and ingroup identity (descent), leading to a diversity of kin-based institutions, including the organizational forms known as clans, lineages and kindreds $(21,27,30)$. The second insight, based on work in psychology, is that people's motivations, emotions, perceptions, thinking styles and other aspects of cognition are heavily influenced by the social norms, social networks, technologies and linguistic worlds they encounter while growing up (31-38). In particular, with intensive kin-based institutions, people's psychological processes adapt to the collectivistic demands and the dense social networks that they interweave (39-43). Intensive kinship norms reward greater conformity, obedience, holistic/relational awareness and in-group loyalty but discourage individualism, independence and analytical thinking $(41,44)$. Since the sociality of intensive kinship is based on people's interpersonal embeddedness, adapting to these institutions tends to reduce people's inclinations towards impartiality, universal (non-relational) moral principles and impersonal trust, fairness and cooperation. Finally, based on historical evidence, the third insight suggests that the branch of Western Christianity that eventually evolved into the Roman Catholic Church-hereafter, 'the Western Church' or simply 'the Church' - systematically undermined the intensive kin-based institutions of Europe during the Middle Ages (45-52). The Church's marriage policies and prohibitions, which we will call the Marriage and Family Program (MFP), meant that by 1500 CE, and likely centuries earlier in some regions, Europe lacked strong kin-based institutions, and was instead dominated by relatively weak, independent and isolated nuclear or stem families (49-51,53-56). This made people exposed to Western Christendom rather unlike nearly all other populations.

Integrating these insights, we propose that the spread of the Church, specifically through its transformation of kinship and marriage, was a key factor behind a cultural shift towards a WEIRDer psychology in Europe. This shift eventually fostered the creation of new formal institutions, including representative governments, individual rights, commercial law and impersonal markets $(17,57)$. This theory predicts that (1) societies with less intensive kin-based institutions should have a WEIRDer psychology and (2) historical exposure to the Church's MFP should predict both less intensive kin-based institutions and, as a consequence, a WEIRDer psychology.

To illuminate these relationships for diverse populations, we (1) developed measures of the intensity of kinbased institutions, (2) created historical databases to estimate the exposure of populations to the Church (along with the MFP) and (3) compiled 20 different psychological outcomes, including laboratory experiments, validated scales, survey questions and ecologically-valid observational data. We examine the predicted relationships from three complementary perspectives. Across countries, we can observe the 
broadest range of variation in the largest number of psychological outcomes. Across regions, we can track the historical Church as it lumbered across Europe and detect its footprints on the psychological patterns and marital arrangements of modern Europeans. Finally, by comparing second-generation immigrants in Europe based on their links to the kin-based institutions of their ancestral communities around the world, we eliminate many alternative hypotheses for the relationships we've illuminated.

\section{Theory}

Our approach proposes that, by structuring and incentivizing the social environments that individuals must navigate, kin-based institutions shape several important aspects of our psychology. Thus, to understand contemporary psychological variation, we need to understand the historical and cultural evolutionary forces that have shaped the intensity and diversity of kin-based institutions globally. In this section, we first explain kin-based institutions, sketch their intensification since the origins of food production, and then describe how they influence aspects of psychology. Lastly, we'll sketch the historical process by which the Church systematically dismantled the intensive kin-based institutions in Europe during the Middle Ages.

Kin-based institutions are perhaps the most fundamental of human institutions, and have long represented the primary framework for organizing social life in most societies $(21,22,29,58)$. These institutions are composed of sets of culturally-transmitted norms that influence a broad range of social relationships by endowing individuals with a set of responsibilities, obligations and privileges vis-à-vis others in their communities (Supplementary S1). Many of these norms are rooted in, or otherwise tap, aspects of our species' evolved psychology, including those related to kin altruism, incest aversion and pair bonding (29, 59, 60). Many kinship systems, for example, extend our species' innate aversion to inbreeding (incest) with close kin to create taboos on marriages to more distant relatives, usually including particular types of cousins (27). Specifically, some societies classify the children of one's parents' same-sex siblings as 'brothers' and 'sisters' (so, no sex or marriage with these 'parallel-cousins') while normatively prescribing or at least permitting marriage to the children of one's parent's opposite-sex siblings ('cross-cousins'). By shaping patterns of marriage, residence and alliance formation, these norms organize social interactions and configure networks in ways that profoundly influence people's minds and behavior $(61,62)$.

While all small-scale societies are organized primarily by kin-based institutions, evidence suggests that the character of these institutions is influenced in important ways by ecological, climatic, economic and geographic factors $(63,64)$. Among mobile hunter-gatherers, cultural evolution has responded to ecological risk by fostering social norms that favor extensive kin ties, which create sprawling relational networks that can be tapped when local disasters strike $(65,66)$. Among Kalahari foragers, for example, first and second cousins are under incest taboos, so parents traditionally arranged marriages for their daughters with distant kinsmen $(65,67,68)$. With the emergence of food production, however, cultural evolution increasingly favored intensive kin-based institutions that permitted communities to unify larger groups to control territories and organize production, storage and distribution $(24,25,69,70)$. Unlike foragers, food producers had to rely on longer-term investments in fields and pastures, which placed a premium on controlling territory and protecting stores. The development of these intensive kin-based institutions proceeded at different rates in different regions, presumably due to a variety of ecological, climatic and geographic factors as well as the eventual formation of pre-modern states $(48,71)$.

Cultural evolution thus responded to the emergence of food production by fostering the emergence of a diversity of new relationship-building institutions that all intensified group solidarity by constructing denser and more interdependent social networks. For example, instead of favoring marriages to distant kin, cultural evolution often favored some form of cousin marriage, which strengthened the existing bonds among families (21). Similarly, unilineal descent systems that create lineages or clans likely emerged because of how bilateral descent systems (common among mobile foragers (72)) create conflicts of interest between the two sides of a person's family $(21,62)$. By tracking descent from a common ancestor, members of a 
clan or lineage tend to see themselves as equally related. This mitigates conflicts of interest within the clan or lineage and promotes stronger in-group loyalty.

Complementing anthropological accounts, experimental work in both psychology and neuroscience suggests that aspects of our cognition, emotions, perceptions, and motivations adapt to the normative demands, reputational incentives, and implicit values of the dense networks spanned by kin-based institutions $(3,15,79,41,42,73-78)$. Research, for example, has shown that people from societies with social norms favoring interdependence attend to scenes more holistically-based on eye-tracking and neural measures - and show better recall in memory tests for background objects (80-82). Since the cultural evolutionary forces driving the development of intensive kinship favored greater in-group solidarity, often with strict lines of command and control, we expect corresponding psychological patterns: kin-based institutions should foster greater conformity, obedience to authorities, nepotism and in-group loyalty but less individualism, creativity and independence. Given the reliance of kin-based institutions on relationshipspecific norms, these institutions should also favor a contextually-sensitive morality rooted in in-group loyalty over impartial standards and universal principles. Kin-based institutions should also inhibit motivations toward prosociality, including trust, cooperation and fairness, towards strangers or impersonal organizations.

The final aspect of our approach incorporates the role of religion and its influence on kin-based institutions. By the start of the Common Era, universalizing religions with powerful moralizing gods (or cosmic forces), universal ethical codes and contingent afterlife beliefs had emerged across the Old World. However, these competing religions varied greatly in how their religious beliefs and practices shaped kin-based institutions $(83,84)$. In Persia, for example, Zoroastrians glorified the marriage of close relatives, including siblings, and encouraged widespread cousin marriage. Later, Islam curbed polygynous marriage (limiting a man to no more than four wives) but also adopted inheritance customs that promoted a nearly unique form of cousin marriage in which a daughter marries her father's brother's son-patrilineal clan endogamy (45-47). Meanwhile, by Late Antiquity, the Church had begun systematically dismantling the intensive kin-based institutions of Western Europe by banning or otherwise undercutting crucial practices. Prior to the Church's efforts, the kin-based institutions of European populations looked much like other agricultural societies and included patrilineal clans, kindreds, cousin marriage, polygyny, ancestor worship and corporate ownership $(47,49,92-94,52,85-91)$. As documented in Supplementary S2, the Church's Marriage and Family Program (MFP) began with targeted bans on certain marriage practices used to sustain marriage alliances between families (e.g., levirate marriage); however, by the Early Middle Ages, the Church had become obsessed with incest and had begun to expand the circle of forbidden relatives, eventually including not only distant cousins but also step-relatives, in-laws and spiritual-kin. Early in the new millennium, the ban was stretched out to encompass sixth cousins, including all affines (Table S2.1). At the same time, the Church promoted marriage 'by choice' (no arranged marriages) and often required newly married couples to set up independent households (neolocal residence). The Church also forced an end to many lineages by eliminating legal adoption, remarriage and all forms of polygamous marriage as well as concubinage, which meant that many lineages began literally dying out as they lacked legitimate heirs. In the $8^{\text {th }}$ century, the Church found a common cause with the Frankish Kings, eventually leading the Carolingian Empire to put its secular power behind the Church's MFP (Table S2.1) (47, 49, 52, 95).

Although quantitative data are lacking for most of the Middle Ages, by 1500 CE European kinship had transformed into a virtually unique configuration, based on monogamous nuclear (or stem) households, bilateral descent, late marriage and neolocal residence (49-51, 53-55, 94, 96, 97). There were few cousin marriages (except among elites with Papal dispensations) and no clans, tribes or kindreds. Land was individually owned, and inheritance was often by testament.

Substantial debates persist about why the Church adopted the MFP, which we summarize in Supplementary S2. Support for the full extent of the MFP policies certainly cannot be found in the Bible, and the other 
branches of Christianity never went so far. Nestorian and Coptic Christians, for example, continued marrying their cousins for at least another millennium. And, while the Eastern Orthodox Church did adopt some of the same prohibitions as the Western Church, it never endorsed the Western Church's broad taboos on cousin marriage, was slow to adopt many policies, and was generally unenthusiastic about enforcement. From a cultural evolutionary point of view, diverse religious communities may coalesce on their own beliefs and practices for idiosyncratic or historically contingent reasons, but the broad diffusion of particular beliefs and practices depend on how they shape long-term success (83). Consistent with this, much evidence indicates that the immense financial success of the Church during the Middle Ages can be tied back to the MFP $(47,49,98)$.

While our approach views the Church's MFP as a critical contributor to the dissolution of intensive kinbased institutions in Europe and to the formation of WEIRD psychology, it does not preclude the existence of other contributors. As noted, ecological, geographic and related factors likely also matter. Moreover, while the Church actively spread to wherever it could, and there was much stochasticity, the diffusion and and implementation of the MFP may have also been influenced by other factors, including by the existing kin-based institutions of the missionized populations. Our analysis addresses these issues in a variety of ways.

\section{Methods}

To test these ideas, we developed two measures of the intensity of kin-based institutions along with measures for the duration of exposure to the Church both at the country level and at the regional level within European countries. We combined these variables with 20 psychological outcome variables, captured at either the country or individual level, that we assembled from diverse sources.

To measure the intensity of kin-based institutions, we created two kinds of measures. First, as an omnibus measure of the overall strength of kin-based institutions, we created a kinship intensity index (KII) based on data from the Ethnographic Atlas $(83,84)$. The Atlas quantifies observations from 1,291 populations based largely on anthropological studies of societies prior to industrialization. We constructed the KII by averaging, for each Atlas ethnicity, measures regarding (1) preferences for cousin marriage (Figure S1.1), (2) polygamy (Figure S1.2), (3) co-residence of extended families (Figure S1.3), (4) community organization (Figure S1.4), and (5) presence of unilineal descent (Figure S1.6). Then, linking these Atlas measures via language phylogenies, we mapped our normalized KII values to 7,651 ethno-linguistic populations around the globe from the Ethnologue (101) (Figure 1, Supplementary S8). For country-level KII measures, we aggregated up from the ethno-linguistic populations, weighted by their population sizes, within each country (Figure S1.7, for a similar approach see (42)).

The five measures that make up our KII each contribute to structuring societies in ways that intensify and multiply social bonds within kin groups (see Supplementary S1.1). The KII makes full use of the available Atlas measures that capture social structure. This omnibus measure of kinship intensity captures the key aspects that the Church's MFP impacted. Because polygynous marriage may impact psychology through alternative mechanisms, related to the intensity of intrasexual competition (60), we show that our results hold when we remove polygyny from the KII and control for it separately (Tables S3.9 and S6.6). 


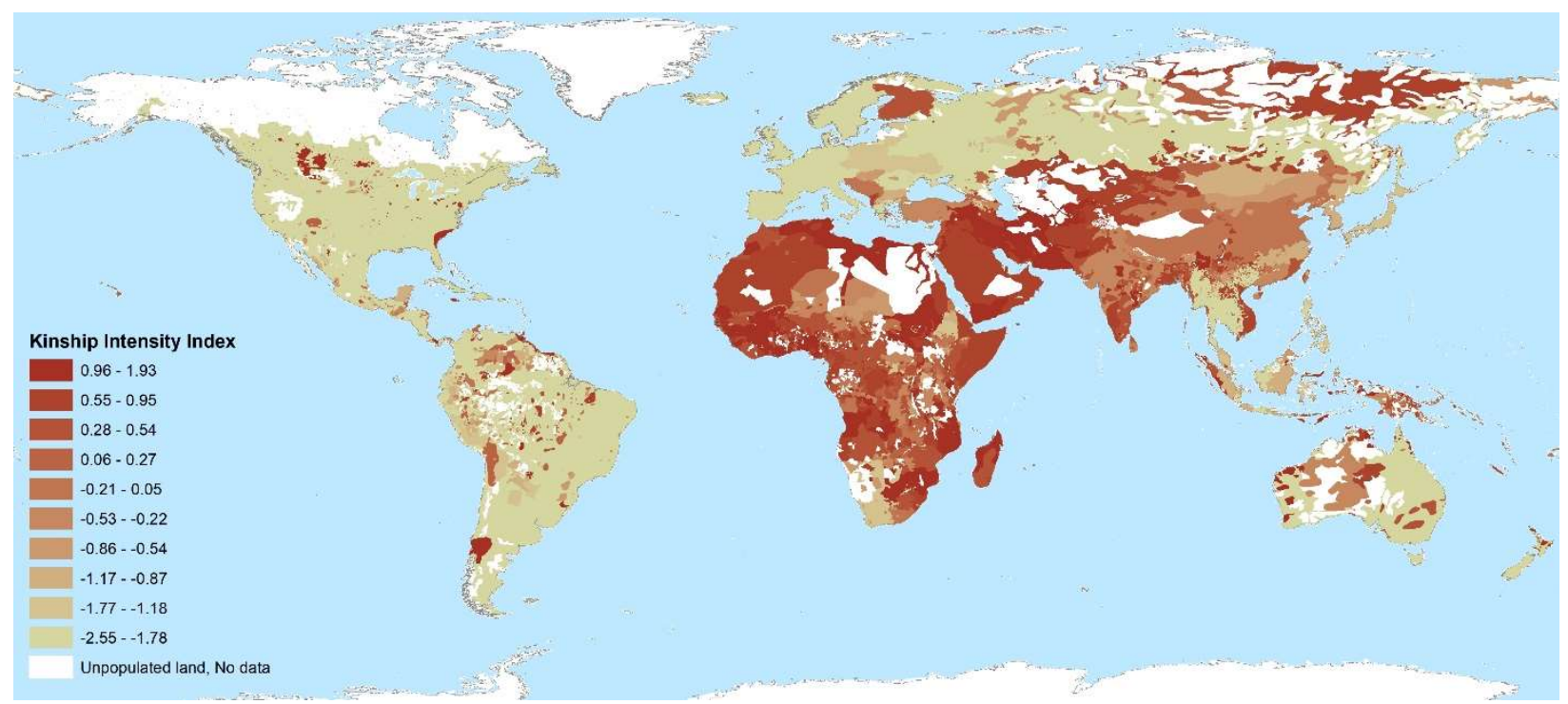

Figure 1. The Kinship Intensity Index (KII) for 7,651 ethno-linguistic populations around the globe.

The KII is a historical measure of the intensity of kin-based institutions, with the average observation occurring around $1900 \mathrm{CE}$. This means that KII measures pre-date our psychological measures by about a century. This is an advantage, since it eliminates the risk of contemporaneous reverse causality and permits us to potentially reveal enduring impacts of kin-based institutions on psychology. Analyses reported in Table S3.7 confirm that the observation years for the KII has no impact on our findings.

As an alternative measure of kinship intensity, we also compiled estimates of the prevalence of cousin marriages in the $20^{\text {th }}$ century, both across countries and within Europe (Supplementary S1.2). Crossnationally, we augmented an existing database (102) of estimates of the prevalence of marriages between couples who were second cousins or closer relatives (hereafter, 'cousin marriage prevalence'; see Figure S1.8). Within Europe, we compiled estimates of the rates of first cousin marriage for regions in Italy, Spain and France during the $20^{\text {th }}$ century based on requests for Papal dispensations (permission to marry cousins). Expanding this, we also incorporated rates of cousin marriage from contemporary Turkey.

As a measure of kinship intensity, cousin marriage complements the KII in three ways. First, unlike the ethnographic observations used to fashion the KII, cousin marriage provides a statistic about what was actually happening in the $20^{\text {th }}$ century. Second, cousin marriage is a particularly important aspect of intensive kinship: it creates thick family networks. Third, cousin marriage represents perhaps the central MFP-related policy difference between the Western and Eastern Churches, with the Western Church implementing and enforcing its extensive prohibitions with greater verve.

To assess the historical exposure of countries and regions to the Churches' MFP, we calculated the duration of exposure to the Church in two ways. At the country level, we created a measure that captures the number of centuries each country was under the sway of either the Western or the Eastern Church prior to 1500 CE. We then adjusted this indicator for population movements that have occurred after the year 1500 (such as the European migration to the Americas; Supplementary S2.2). This gives us separate country-level measures for Western Church exposure (Figure S2.1) and Eastern Church exposure (Figure S2.2) based on contemporary population distributions.

Within Europe, we calculated a similar dosage measure for 440 regions based on the diffusion of bishoprics - regional administrative centers within the Western Church's hierarchy - through space and time (Figure S2.3). To calculate regional Church exposure, we first divided Europe's surface into pixels 
$\left(0.125 \times 0.125\right.$ decimal degrees or around $\left.14 \mathrm{~km}^{2}\right)$. Then, for every pixel and for every half century from 550 to $1500 \mathrm{CE}$, we coded a binary variable as ' 1 ' if there was an active bishopric within $100 \mathrm{~km}(\sim 2-3$ days travel, (103)) of the pixel's centroid. Finally, we calculated each region's Church exposure by taking the mean across all the pixels in the region and across all half-centuries. Figure 2 plots Church exposures for European regions.

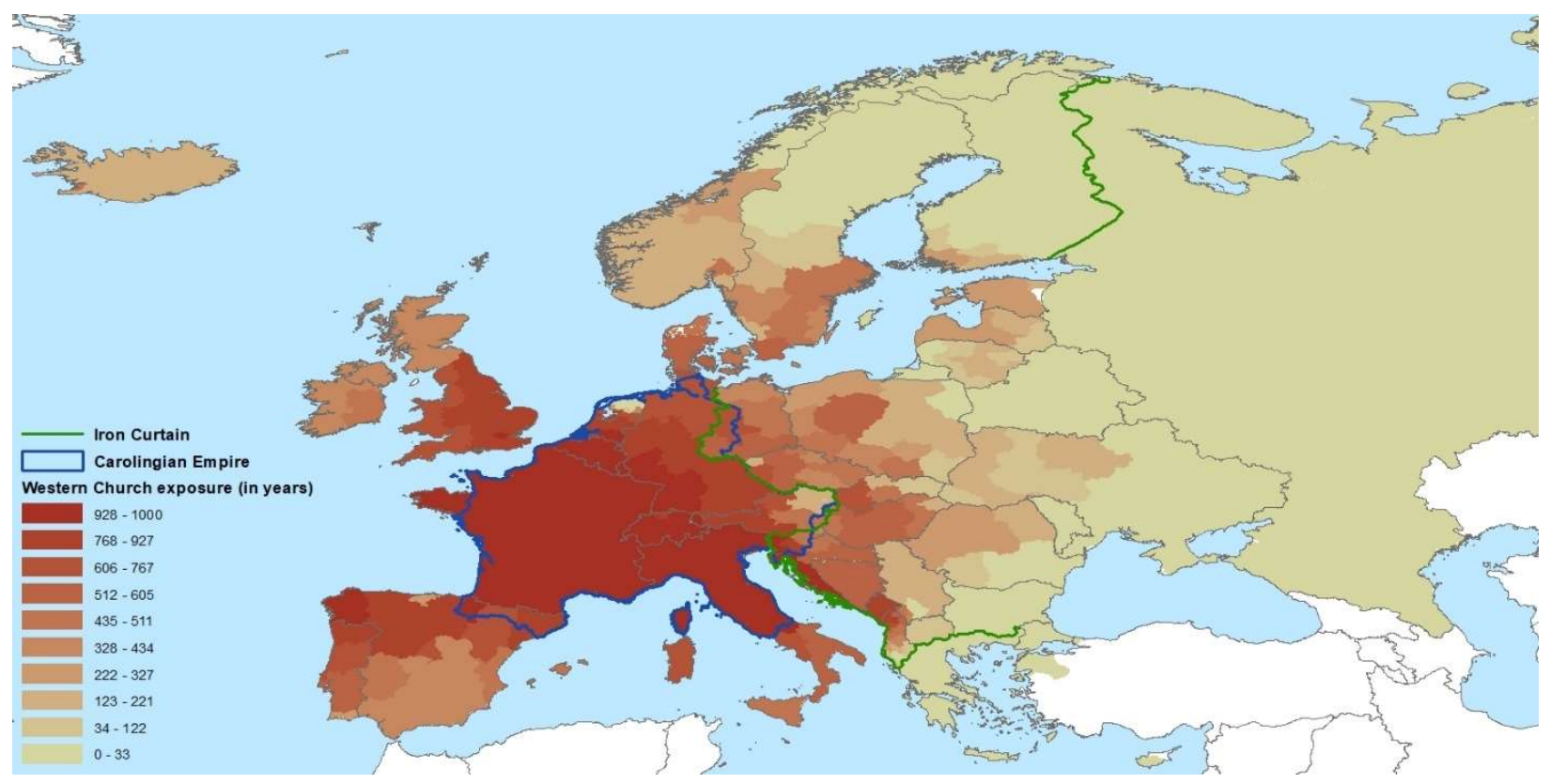

Figure 2. Western Church exposure across European regions. The map shows regional Church exposure between 550 and 1500CE and contains the boundaries of the Carolingian Empire (blue line) and the divide between Western and Socialist Europe (green line; following Churchill's speech on the "Iron Curtain", we included the former Yugoslavia in Socialist Europe, even though it was not part of the Warsaw pact).

To connect our effort to important work on family ties $(39,40)$, we confirm that both of our historical measures of kin-based institutions, as well as Church exposure, predict the value that contemporary populations place on "family ties" (Figure S2.6 and Table S3.5).

To capture the theoretically relevant psychological dimensions, we compiled data on 20 variables, which we group in three packages: (1) individualism \& independence, (2) conformity \& obedience, and (3) impersonal prosociality. Table 1 briefly describes and lists the 20 variables by package. Here, we supplement the descriptions in Table 1 with more detail for some of the variables, but unfamiliar readers can find complete descriptions in Supplementary S9. Our individualism \& independence package includes two survey questions along with Hofstede's classic measure of individualism and a task that uses triads to assess people's reliance on analytic vs. holistic thinking. In that task, participants are asked in a series of triads to say whether a target, such as a rabbit, goes with a dog or a carrot. The pairings are either analytical, based on abstract categories (rabbits and dogs are both mammals), or relational/functional (rabbits eat carrots).

Our conformity \& obedience package includes three survey measures, one psychological scale (tightness) and one experiment (the Asch conformity task). In the Asch conformity experiment, undergraduates were asked to judge over a series of trials which of a set of lines was longest. During certain critical trials, participants heard their peers, who were actually experimental confederates, give the same incorrect judgment just prior to their turn. Because these judgements are easy- $97 \%$ or more of people get them correct by themselves - the average percentage of incorrect responses in each country provides a countrylevel measure of conformity. 
Our impersonal prosociality package has been broken down into two subcategories, one focused on impartiality and the other on impersonal cooperation and trust. Of the impartiality measures, only the honesty dice game requires more explanation. In this experiment, students were isolated in a cubicle and asked to anonymously report their roll of a six-sided die. For rolls from one to five, they were paid in proportion to their reported roll, with ' 5 ' making the most money. A roll of ' 6 ', however, was worth zero. At the country level, the percentage of people claiming a 'high roll' (a ' 3 ', '4', or ' 5 ') provides a measure of dishonesty, since we know that only $50 \%$ of rolls can be 'high', on average. This measure correlates strongly with country-level measures of corruption and tax evasion (6).

For impersonal cooperation and trust, we analyzed two laboratory experiments derived from versions of the public goods game (PGG), one real-world measure of public goods contributions based on voluntary blood donations, and three survey questions about trust and fairness. Since our theory suggests that the fault line created by intensive kinship lies between outgroups or strangers and the binding interpersonal ties of one's in-group, we follow other researchers $(42,104)$ in constructing a country-level measure of impersonal trust using six questions from the World Values Survey (WVS). To construct the out-ingroup trust measure, we first created an in-group measure of trust by averaging people's reported trust towards (1) their families, (2) their neighbors and (3) people they know. Then, we created an outgroup trust measure based on people's reports about their trust in (1) foreigners, (2) people they've met for the first time, and (3) people from other religions. Finally, we subtracted our outgroup trust measure from our ingroup measure (and standardized it). 


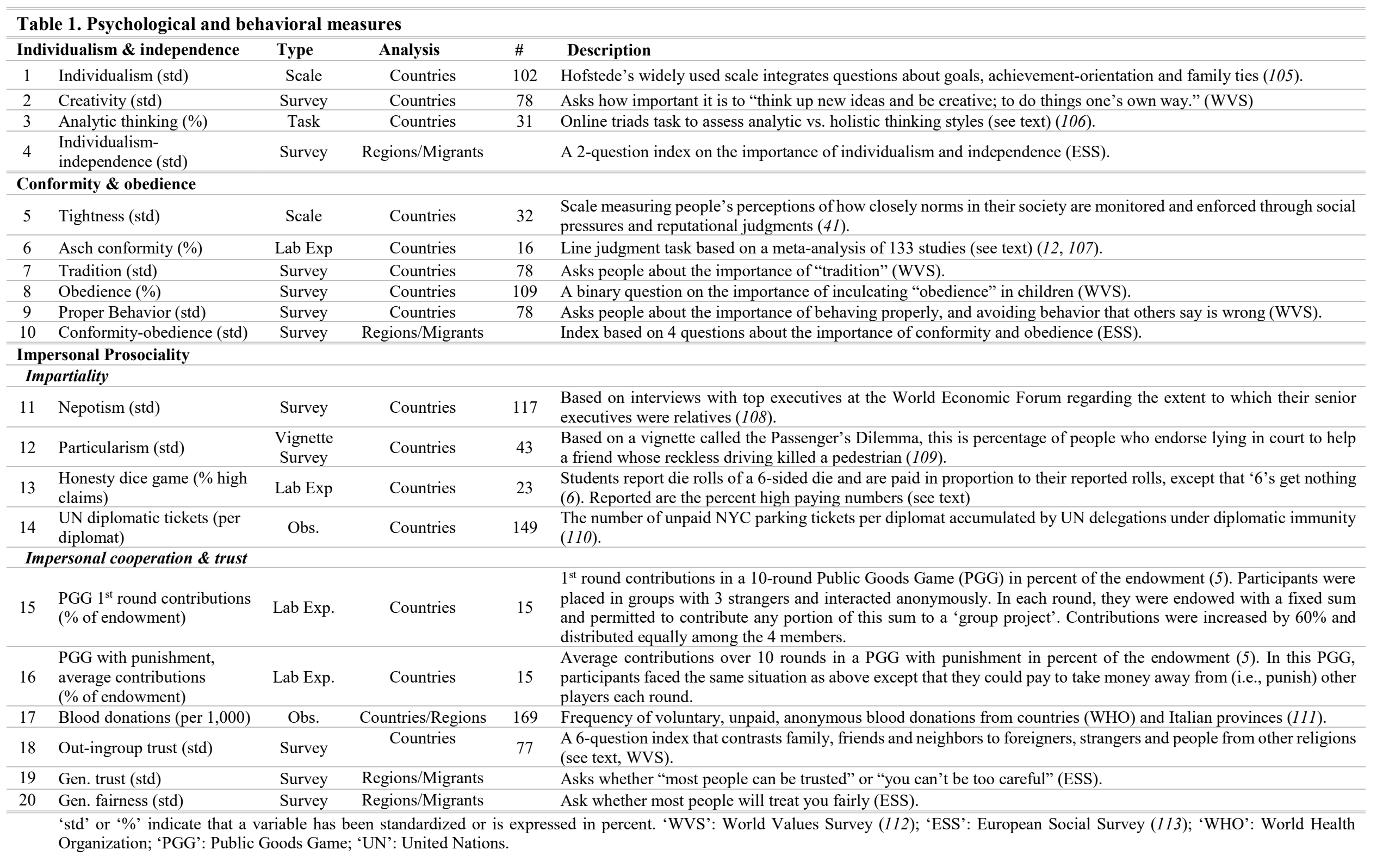


To measure impersonal trust within Europe, we used the commonly used generalized trust question, which asks whether "most people can be trusted" or "you can't be too careful". However, detailed analyses suggest that while in Europe this question is interpreted as intended, to refer to trust in generic strangers, it is not consistently interpreted in this way everywhere (Supplementary S7). In places where people have embedded themselves both physically and relationally in dense networks of interpersonal ties, many report that most people can be trusted in response to the generalized trust question, while also reporting that they don't trust foreigners, new people or those from other religions. For this reason, we use both the generalized trust and generalized fairness survey questions within Europe but drop both in our cross-country analyses (though the results are reported in Supplementary S3.3B).

\section{Results}

We present our findings in three major stages. In the first stage, we examine cross-country patterns. This allows us to tap the broadest range of psychological outcomes (16 variables) and illustrates the breadth of contemporary global variation. We examine the relationships between our outcomes and both our countrylevel measures of kinship intensity - the KII and the prevalence of cousin marriage - and Church exposure. We also confirm that greater Church exposure is associated with less intensive kinship. In the second stage, we zoom in on Europe and examine the relationships between four survey-based outcomes and both regional Church exposure and cousin marriage. Again, as in the cross-country analysis, we confirm that longer exposure to the Western Church is associated with weaker kin-based institutions. Finally, in the third stage, we compare only the adult children of immigrants within European countries. We establish links between the kinship intensities of people's immigrant parents - based on the parents' native countries or their originating ethno-linguistic populations - and our four survey-based psychological measures. In addition, further confirming our findings, Supplementary S7 reports the results of analyses that relate psychological measures drawn from the WVS to variation in the kinship intensities of the ethno-linguistic populations within countries around the globe.

\section{Psychological variation across countries}

Figures 3-6 show the relationships between our outcomes and (1) the KII, (2) cousin marriage prevalence and (3) Western and Eastern Church exposure. For our individualism \& independence package, Figure 3 shows that less intensive kinship, measured by either the KII or cousin marriage, and more Church exposure are associated with a WEIRDer psychology - i.e., with greater individualism, increased creativity and more analytic thinking. All of these relationships go in the predicted directions. The Spearman correlations range in magnitude from 0.10 to 0.70 . The only result that is not significant at the $5 \%$ level (on a one-sided test) is that between the KII and analytic thinking, which is not surprising given the limited variation in KII available in that small sample $(N=29)$. (Throughout, we report the significance of our estimates on onesided tests because our theory makes clear predictions about the directions of the associations we examine.) 

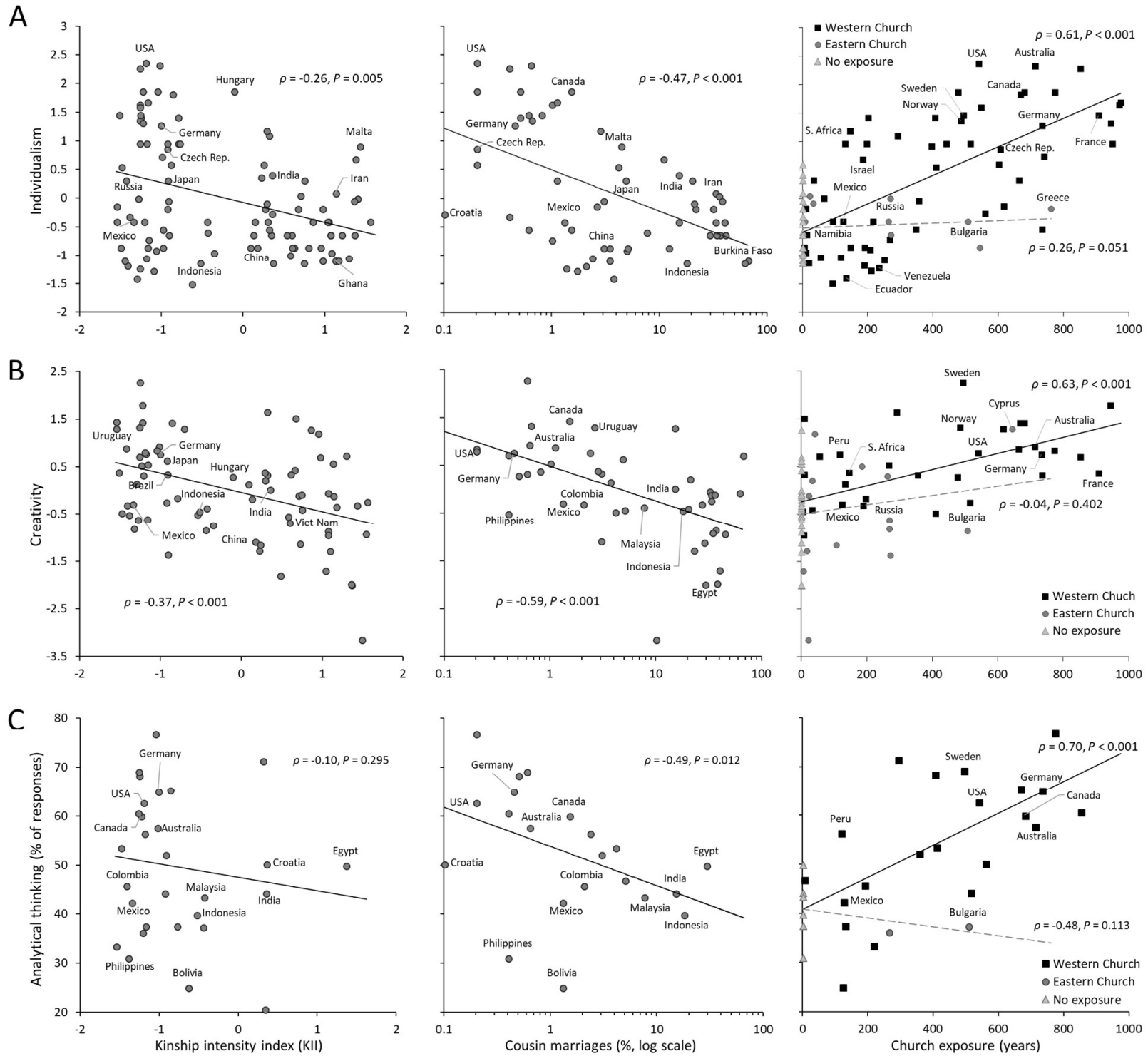

Figure 3. Individualism $\&$ independence, kinship intensity and Church exposure. The figure shows the crosscountry relationship between our psychological outcomes - individualism (row A), creativity (row B), and analytic thinking (row C) - and the KII ( $1^{\text {st }}$ column), cousin marriage prevalence $\left(2^{\text {nd }}\right.$ column) and both the Western and Eastern Church exposures $\left(3^{\text {rd }}\right.$ column). Linear best-fit lines are displayed; in the third column, the solid and dashed lines plot the best-fit for the Western and Eastern Churches, respectively. Reported are Spearman's $\rho$ and associated significance levels (one-sided). 

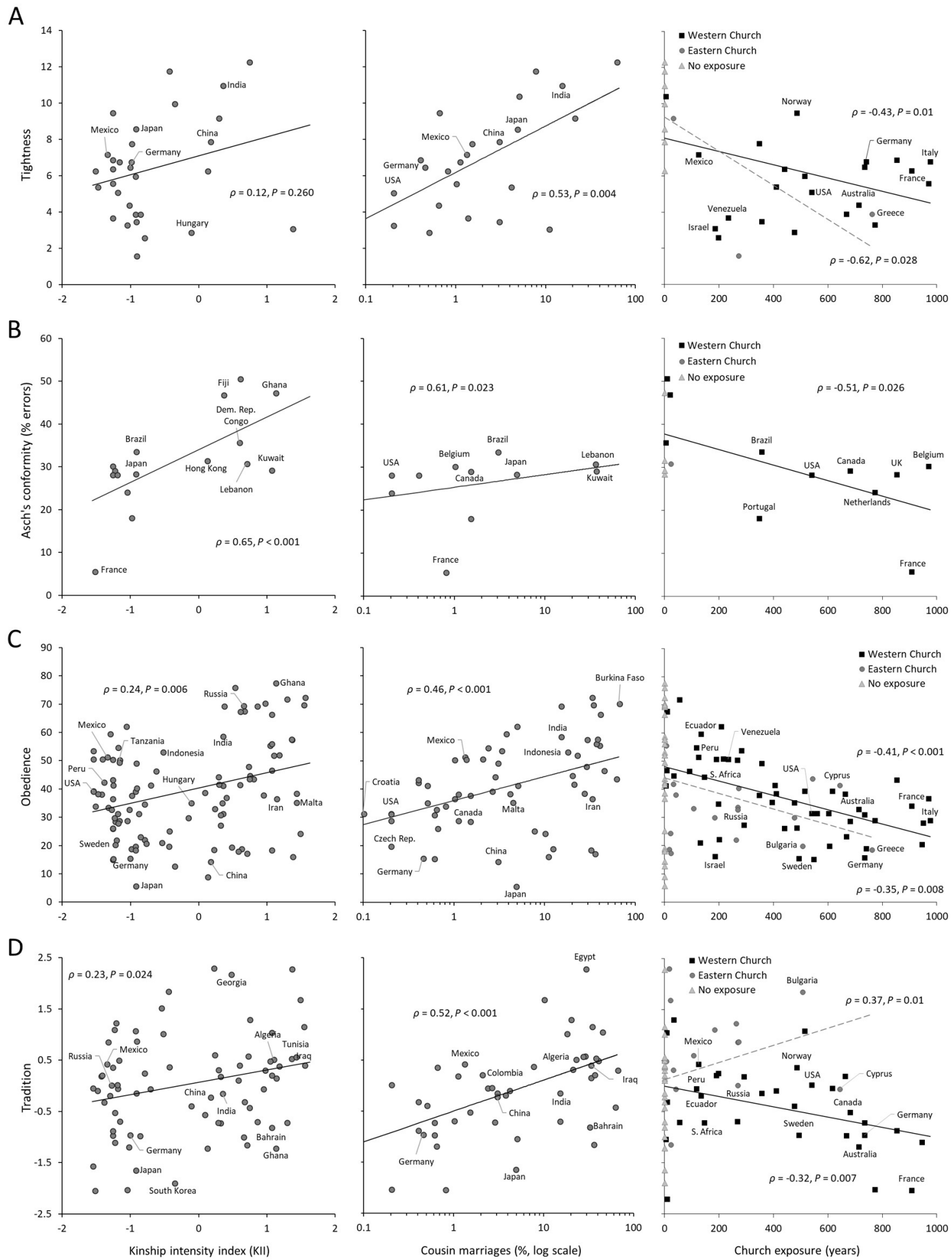

Figure 4. Conformity \& obedience, kinship intensity and Church exposure. The figure shows the cross-country relationship between our psychological outcomes - tightness (row A), Asch conformity (row B), obedience (row C) and tradition (row D) - with the KII ( $\left(1^{\text {st }}\right.$ column), cousin marriage prevalence $\left(2^{\text {nd }}\right.$ column) and both the Western and Eastern Church exposures ( $3^{\text {rd }}$ column). Linear best-fit lines are displayed; in the third column, the solid and dashed lines plot the best-fit for the Western and Eastern Churches, respectively. Reported are Spearman's $\rho$ and associated significance levels (one-sided). 
A

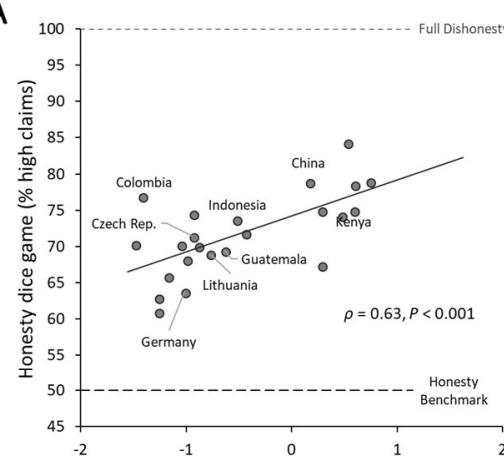

B

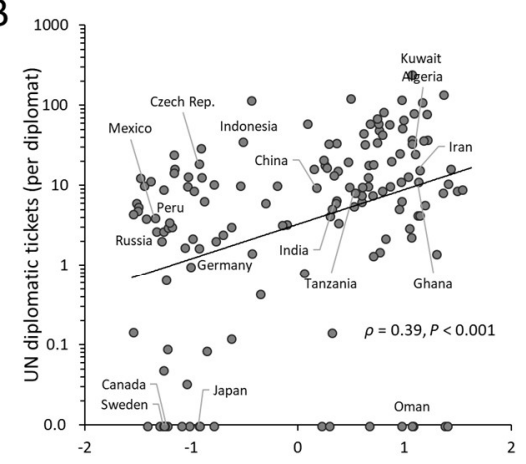

C

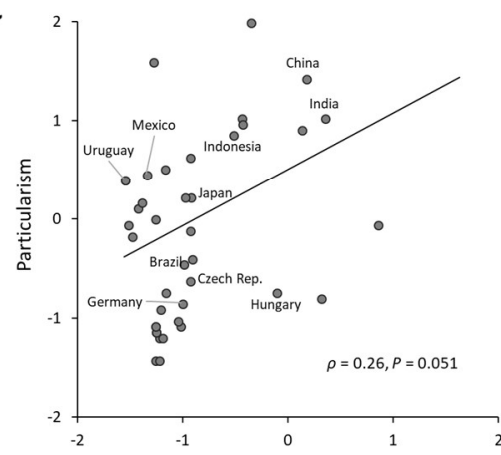

D

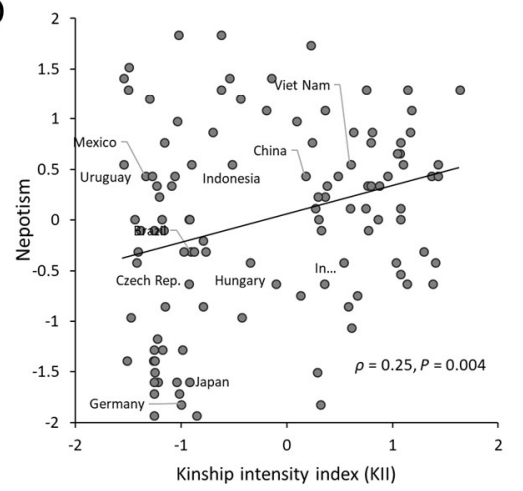

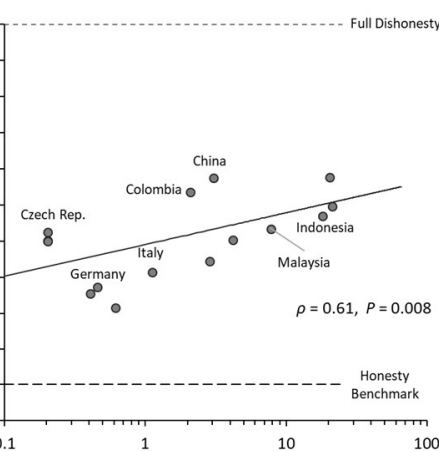
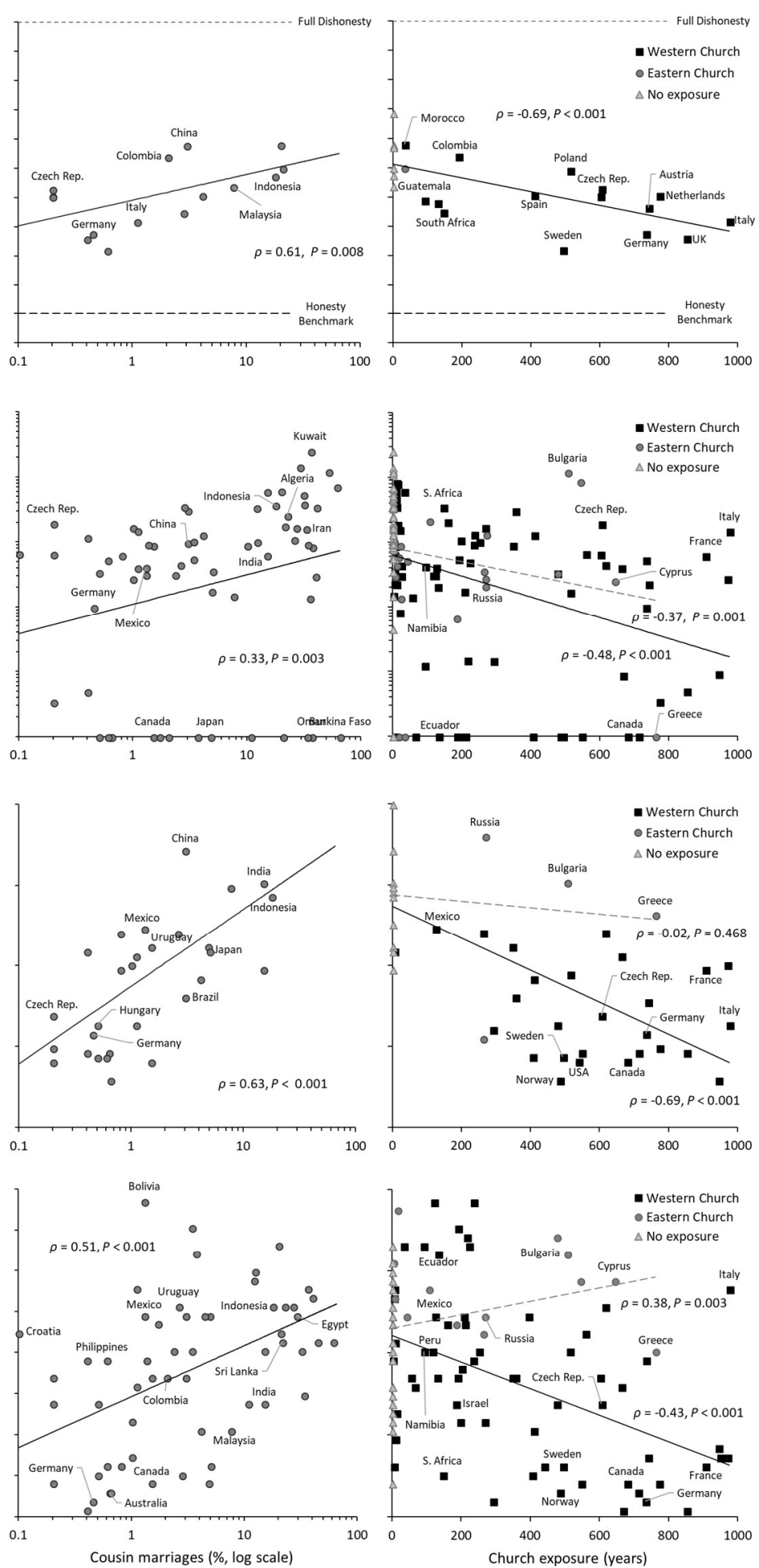

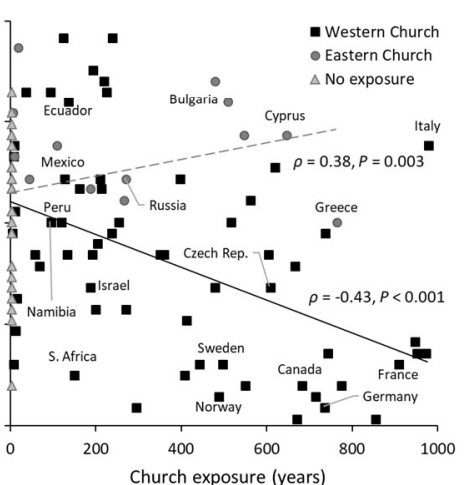

Figure 5. Impartiality, kinship intensity and Church exposure. The figure shows the cross-country relationship between our psychological outcomes-high claims (\%) in the honesty dice game (row A), UN diplomatic tickets (unpaid parking fines; row B), particularism (row C) and nepotism (row D) - and the KII ( $1^{\text {st }}$ column), cousin marriage prevalence $\left(2^{\text {nd }}\right.$ column$)$ and both the Western and Eastern Church exposure ( $3^{\text {rd }}$ column). Linear best-fit lines are displayed; in the third column, the solid and dashed lines plot the best-fit for the Western and Eastern Churches, respectively. Reported are Spearman's $\rho$ and associated significance levels (one-sided). 
A

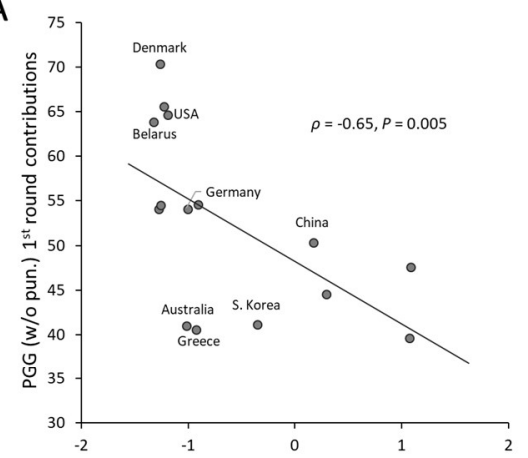

B

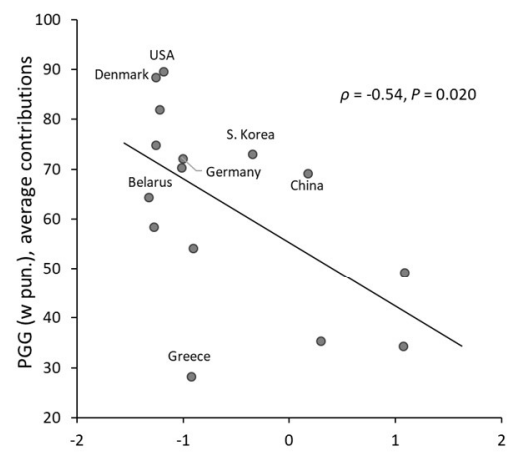

C

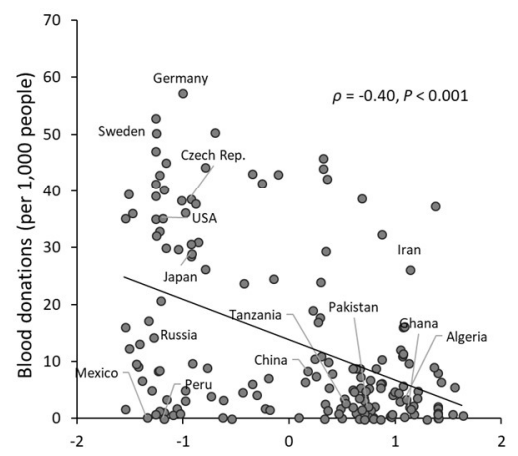

D

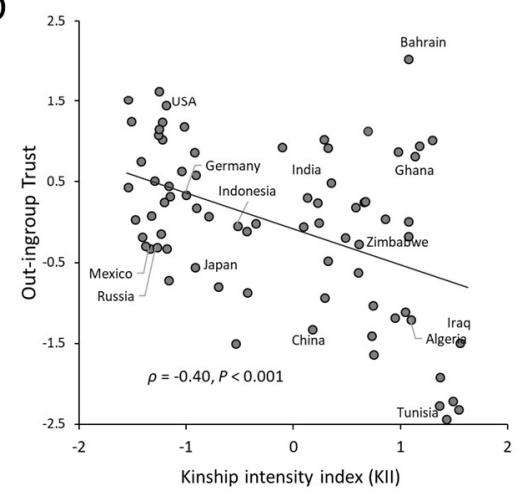

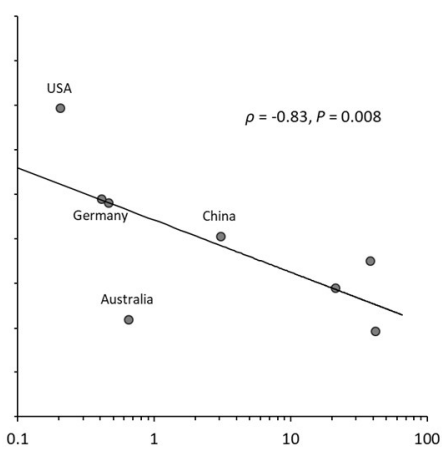
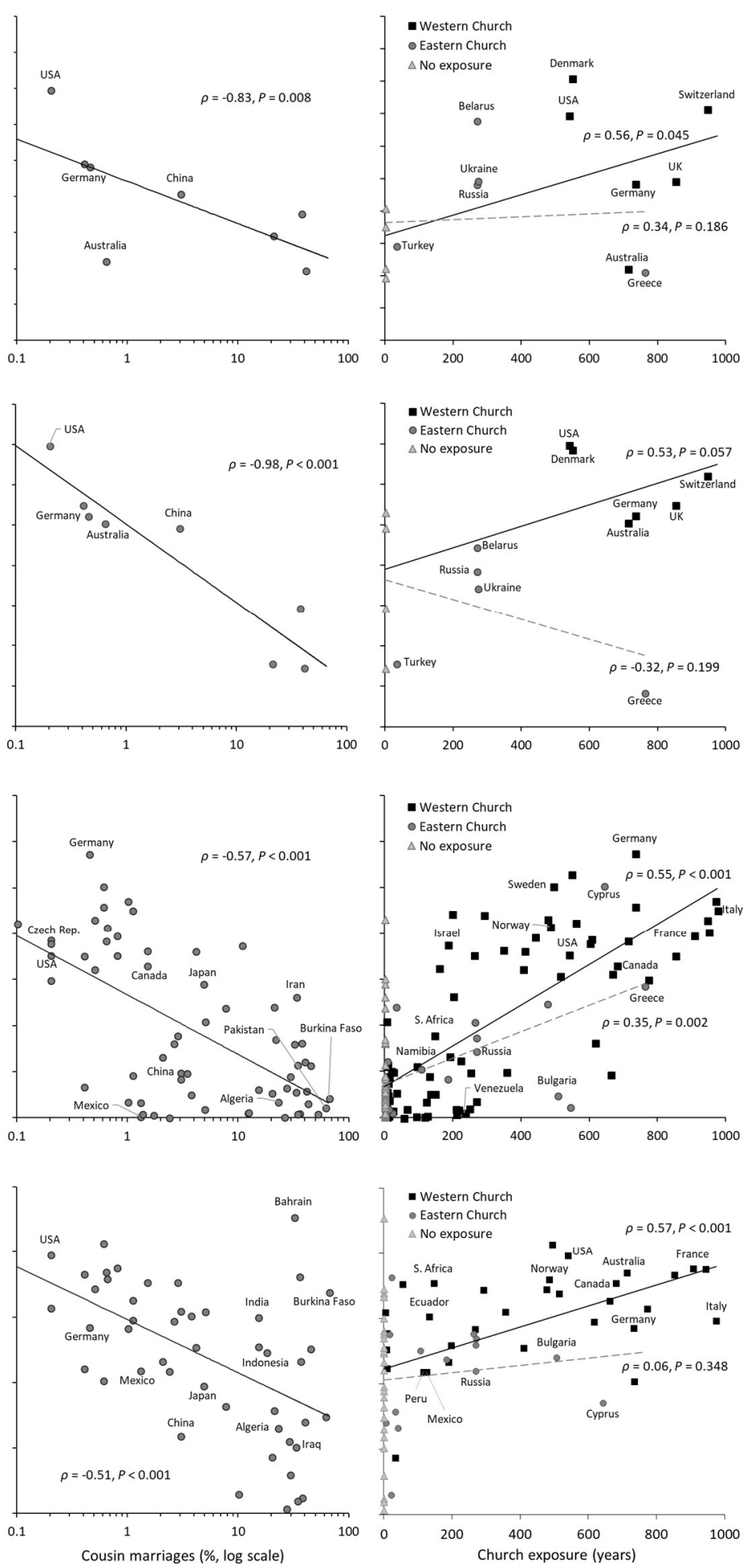

Figure 6. Impersonal cooperation $\&$ trust, kinship intensity and Church exposure. The figure shows the crosscountry relationship between our psychological outcomes $-1^{\text {st }}$ round PGG contributions (row A), average PGG contribution with punishment (row B), blood donations (row C), and out-ingroup trust (row D) - and the KII ( $1^{\text {st }}$ column), cousin marriage prevalence ( $2^{\text {nd }}$ column) and both the Western and Eastern Church exposure ( $3^{\text {rd }}$ column). Linear best-fit lines are displayed; in the third column, the solid and dashed lines plot the best-fit for the Western and Eastern Churches, respectively. Reported are Spearman's $\rho$ and associated significance levels (one-sided). 
Figure 4 shows that intensive kinship is negatively correlated with a WEIRDer psychology in our conformity \& obedience package: more intensive kinship is associated with greater psychological tightness, more conformity (Asch task), more importance attributed to obedience and increased devotion to tradition. Similarly, greater Church exposure is associated with less tightness, less conformity, lower rates of conformity and a reduced emphasis on obedience and tradition. All relationships go in the predicted direction, with Spearman correlations ranging in magnitude from 0.12 to 0.65 . All are significant except the relationship between tightness and the KII, whose lack of significance may again be due to the limited variation in the KII in this small sample $(N=31)$. The fifth variable of our conformity \& obedience package, proper behavior (not shown), reveals no relationship to any of our key theoretical predictors (Figure S3.1).

For the impartiality sub-package, Figure 5 shows the 12 key relationships, all of which go in the predicted directions with Spearman correlations ranging in magnitude from 0.25 to 0.69 . Based on laboratory and field measures, Figure 6A and 6B show that greater kinship intensity and less exposure to the Western Church are associated with fewer accurate reports of die rolls, more parking tickets for diplomats under immunity, and a greater acceptance of lying in court to help a friend. Figure 6D shows that more intensive kinship and less Church exposure are associated with more nepotistic hiring practices. All associations are significant except that between particularism and the KII $(P=0.051)$, which is likely influenced by the limited variation in KII available in that small sample $(N=42)$.

Figure 6 shows the results from the impersonal cooperation \& trust sub-package. Figures 5A and 5B reveal that less intensive kinship and more Church exposure are associated with higher contributions in both the first round of a standard PGG and across all rounds in a PGG with punishment. These experimental findings are further grounded in the real-world by Figure 5C, which reveals parallel patterns when blood donations are analyzed. Figure 5D shows that greater kinship intensity and less Western Church exposure are associated with a sharper distinction between in-group (e.g., family and neighbors) and out-group members (e.g., foreigners, new people). All the relationships in Figure 5 go in the expected direction, with less intensive kinship and more Church exposure associated with a WEIRDer psychology, and with Spearman correlations ranging in magnitude from 0.40 to 0.98 . All correlations are significant except that between Church exposure and average contributions in a PGG with punishment (Figure 5A, column 3), where although the relationship is strong $(\rho=0.53)$, the few data points $(N=10)$ limit inference.

Along with exposure measures for the Western Church, Figures 3-6 also show the relationships for each of our psychological outcomes and exposure to the Eastern Church. As expected given the lower intensity with which the Eastern Church implemented and enforced its MFP, the relationship with the Eastern Church often resembles that with the Western Church-in 9 of 13 cases - but remains weaker and is often not significant. (We note that fewer countries were exposed to the Eastern Church, which limits statistical power.)

Our primary goal in presenting these cross-country relationships has been to reveal the extent of global psychological variation and show how it patterns in ways consistent with our theoretical expectations. However, to further test the robustness of these relationships, we also estimated 24 additional regression models for each of the eight psychological outcomes for which we have sufficient sample sizes $(N \geq 40)$. In our baseline model, we regressed each outcome on (1) the KII, (2) cousin marriage prevalence or (3) the two Church exposures (both in the same regression), separately, and on four geographic control variables: agricultural suitability, absolute latitude, mean distance to waterways and average terrain ruggedness (Supplementary S3). Each of these controls has previously been associated with economic development, colonial expansion or productivity.

Table 2 presents the results for our baseline models. For each outcome, the associated column provides the four relevant coefficients from three separate regression models (distinguished by shading). The results show that, holding the four geographic controls constant, 23 of the 24 theoretically relevant coefficients go 
in the predicted direction and 22 of the 24 coefficients are significantly different from zero. The effect sizes are moderate to large. For example, a one-standard-deviation increase in the KII is associated with a change of between a quarter and half of a standard deviation in tradition, creativity and out-ingroup trust (all in the predicted direction). Similarly, an additional 500 years of exposure to the Western Church is associated with a change of between 0.80 and 1.15 standard deviations in tradition, creativity and out-ingroup trust. In contrast, for the Eastern Church, the relationships between our psychological outcomes and Church exposure essentially disappear.

\begin{tabular}{|c|c|c|c|c|c|c|c|c|}
\hline \multirow[b]{2}{*}{ Predictors } & \multicolumn{2}{|c|}{$\begin{array}{c}\text { Individualism \& } \\
\text { Independence }\end{array}$} & \multicolumn{2}{|c|}{$\begin{array}{c}\text { Conformity \& } \\
\text { obedience }\end{array}$} & \multicolumn{4}{|c|}{ Impersonal prosociality } \\
\hline & $\begin{array}{l}\text { Indivi- } \\
\text { dualism }\end{array}$ & $\begin{array}{l}\text { Creativ- } \\
\text { ity }\end{array}$ & $\begin{array}{c}\text { Obedience } \\
(\%)\end{array}$ & $\begin{array}{l}\text { Tradi- } \\
\text { tion }\end{array}$ & $\begin{array}{l}\text { UN-Tickets } \\
\text { (logged) }\end{array}$ & $\begin{array}{c}\text { Nepo- } \\
\text { tism }\end{array}$ & $\begin{array}{c}\text { Blood } \\
\text { donation } \\
(\text { per } 1 \mathrm{~K})\end{array}$ & $\begin{array}{l}\text { Out- } \\
\text { ingroup } \\
\text { trust }\end{array}$ \\
\hline KII & $\begin{array}{l}-0.15^{* *} \\
(0.07)\end{array}$ & $\begin{array}{c}-0.37^{* * *} \\
(0.13)\end{array}$ & $\begin{array}{l}2.90^{* *} \\
(1.44)\end{array}$ & $\begin{array}{l}0.23^{* *} \\
(0.11)\end{array}$ & $\begin{array}{l}0.52^{* * *} \\
(0.13)\end{array}$ & $\begin{array}{l}0.15^{* *} \\
(0.09)\end{array}$ & $\begin{array}{c}-2.84^{* * *} \\
(1.06)\end{array}$ & $\begin{array}{c}-0.40^{* * *} \\
(0.12)\end{array}$ \\
\hline$N$ & 93 & 71 & 96 & 71 & 141 & 108 & 138 & 70 \\
\hline $\begin{array}{l}\text { Cousin marriage } \\
(\%, \log )\end{array}$ & $\begin{array}{l}-0.14^{*} \\
(0.07)\end{array}$ & $\begin{array}{l}-0.23^{* *} \\
(0.08)\end{array}$ & $\begin{array}{l}1.63 \\
(1.16)\end{array}$ & $\begin{array}{l}0.18^{* *} \\
(0.07)\end{array}$ & $\begin{array}{l}0.31^{* *} \\
(0.15)\end{array}$ & $\begin{array}{l}0.23^{* * *} \\
(0.08)\end{array}$ & $\begin{array}{l}-2.06^{* *} \\
(0.91)\end{array}$ & $\begin{array}{c}-0.32^{* * *} \\
(0.11)\end{array}$ \\
\hline$N$ & 57 & 44 & 56 & 44 & 64 & 55 & 62 & 44 \\
\hline $\begin{array}{l}\text { W. Church exp. } \\
\text { (in } 100 \text { yrs.) }\end{array}$ & $\begin{array}{l}0.14^{* * *} \\
(0.03)\end{array}$ & $\begin{array}{l}0.21^{* * *} \\
(0.04)\end{array}$ & $\begin{array}{c}0.10 \\
(0.55)\end{array}$ & $\begin{array}{c}-0.16^{* * *} \\
(0.05)\end{array}$ & $\begin{array}{l}-0.14^{* *} \\
(0.06)\end{array}$ & $\begin{array}{l}-0.13^{* * *} \\
(0.04)\end{array}$ & $\begin{array}{l}2.77^{* * *} \\
(0.46)\end{array}$ & $\begin{array}{l}0.18^{* * *} \\
(0.04)\end{array}$ \\
\hline $\begin{array}{l}\text { E. Church exp. } \\
\text { (in } 100 \mathrm{yrs} \text {.) }\end{array}$ & $\begin{array}{l}-0.07 \\
(0.06)\end{array}$ & $\begin{array}{c}0.07 \\
(0.12)\end{array}$ & $\begin{array}{c}0.55 \\
(1.14)\end{array}$ & $\begin{array}{c}0.15 \\
(0.14)\end{array}$ & $\begin{array}{l}-0.01 \\
(0.14)\end{array}$ & $\begin{array}{c}0.09 \\
(0.07)\end{array}$ & $\begin{array}{l}1.21 \\
(1.45)\end{array}$ & $\begin{array}{c}0.02 \\
(0.06)\end{array}$ \\
\hline$N$ & 92 & 68 & 92 & 68 & 137 & 104 & 135 & 67 \\
\hline
\end{tabular}

Country-level regressions of psychological outcomes with data from more than 40 countries on the KII, log \% cousin marriage, and Western and Eastern Church exposure. Outcome variables were standardized ( $z$-scores) unless otherwise indicated. All regressions include our set of baseline controls: ruggedness, mean distance to waterways, caloric suitability and absolute latitude. Robust standard errors are reported in parentheses. * $\mathrm{P}<=0.05$, ** $\mathrm{P}<=0.01, * * * \mathrm{P}<=0.005$ (one-sided). 
In addition to these baseline models, Supplementary S3 explores the effect of separately adding control variables for (1) parasite stress and tropical regions, (2) irrigation potential, (3) suitability for oats and rye, (4) time since the origins of agriculture and genetic heterogeneity (expected heterozygosity), (5) major religious traditions (Catholic, Protestant, Orthodox, other Christian, Islam, Hinduism and Buddhism), (6) religiosity and (7) continental fixed effects. Thus, for each of our psychological outcome variables, we estimated three simple correlations (Figures 3-6), three baseline models (Table 2) and 21 models that added each of these seven variable sets to our baseline model, giving us 27 models. For our individualism \& independence package (two outcomes, shown in Table 2), the coefficients on our three key theoretical predictors were in the hypothesized direction in 52 out of 54 models and significant in 43 models. For our conformity \& obedience package (two variables), the coefficients were in the predicted direction in 45 of 54 models and significant in 26 models. For the impersonal prosociality package (four variables), 105 out of 108 coefficients were in the predicted direction and 81 of these were significant. The detailed regression results are reported in Tables S3.1-S3.4.

Countries, of course, do not represent truly independent observations, which means that our standard errors in these models may be biased. To address this, we re-estimated our main regressions using Conley standard errors (114), to account for similarities among countries induced by either spatial proximity or by a shared genetic/cultural history. These results confirm that the above findings are robust (Table S3.6).

Focusing now on the link between Church exposure and intensive kinship, our cross-country analyses confirm that nations with more centuries of exposure to the Church have less intensive kin-based institutions and lower rates of cousin marriage (Table S3.10). Each additional 500 years under the Western Church is associated with a reduction of 1.2 standard deviations in the KII and a $91 \%$ decline in cousin marriage rates. These results are robust to the addition of the baseline geographic controls and hold across all seven of the supplementary specifications described above. Moreover, Church exposure accounts for a substantial part of the variation in the KII $\left(\mathrm{R}^{2}: 40 \%\right)$ and cousin marriage rates $\left(\mathrm{R}^{2}: 62 \%\right)$. Partial $\mathrm{R}^{2} \mathrm{~s}$ underscore this: Church exposure explains about $20 \%$ of the variation in both the KII and cousin marriage rates beyond the variation already explained by the baseline geographic controls.

While these cross-country analyses reveal patterns fully consistent with our hypotheses, such analyses are fraught with potential confounds, including differences in endogenous variables like national wealth, effective governments and the rule of law. To better map the causal pathways involved, we now zoom in on Europe.

\section{Psychological Variation within Europe}

To explain the psychological variation within Europe, we combine four survey-based measures with estimates of cousin marriage rates and our measure of regional Church exposure. We first link our psychological outcomes to Church exposure, and then confirm their connection to cousin marriage rates in the $20^{\text {th }}$ century. We also confirm that greater historical Church exposure is associated with less cousin marriage. Finally, we study the relationship between cousin marriage and voluntary blood donations in Italy.

We regressed each of our four psychological outcomes on Church exposure across 11 different models, including a simple regression. Table 3 shows two of these models for each of our psychological outcomes. The first model includes our four baseline (geographic) controls, individual demographics (age, age squared and sex) and both country and survey-wave fixed effects. The second model adds individual-level measures of religiosity and denomination (Roman Catholic, Protestant, Muslim, etc.). By absorbing all the variation between countries (i.e., the mean country differences), the country fixed effects allow us to effectively only compare individuals from different regions within the same countries. Table 3 shows that Europeans from regions that were under the sway of the Western Church for longer tend to have a WEIRDer psychology: 
they reveal higher individualism-independence, less conformity-obedience and both greater generalized trust and generalized fairness. Considering that Europe was fully Christianized by $1500 \mathrm{CE}$, these effects are large. An additional millennium under the Western Church is associated with increases in these psychological outcomes of roughly one-tenth of a standard deviation. Importantly, consistent with our theory that emphasizes the medieval Church's MPF and not other religious factors, these effects hold or actually increase in magnitude when religiosity and denomination are statistically held constant.

\begin{tabular}{|c|c|c|c|c|c|c|c|c|}
\hline \multirow{4}{*}{$\begin{array}{c}\text { Variables } \\
\text { Church exposure } \\
\text { (in } 100 \text { yrs.) } \\
N\end{array}$} & \multicolumn{2}{|c|}{$\begin{array}{l}\text { Individualism- } \\
\text { independence }\end{array}$} & \multicolumn{2}{|c|}{ Conformity-obedience } & \multicolumn{2}{|c|}{ Impersonal trust } & \multicolumn{2}{|c|}{ Impersonal fairness } \\
\hline & $0.010^{* *}$ & $0.012^{* * *}$ & $-0.010^{*}$ & $-0.017^{* * *}$ & $0.010^{* * *}$ & $0.011^{* * *}$ & $0.011^{* * *}$ & $0.012^{* * *}$ \\
\hline & $(0.004)$ & $(0.004)$ & $(0.006)$ & $(0.005)$ & $(0.003)$ & $(0.004)$ & $(0.003)$ & $(0.003)$ \\
\hline & 179,827 & 179,827 & 179,827 & 179,827 & 198,449 & 198,449 & 197,112 & 197,112 \\
\hline No. regions & 439 & 439 & 439 & 439 & 440 & 440 & 440 & 440 \\
\hline Basic & Yes & Yes & Yes & Yes & Yes & Yes & Yes & Yes \\
\hline $\begin{array}{l}\text { Religiosity \& } \\
\text { Denomination }\end{array}$ & No & Yes & No & Yes & No & Yes & No & Yes \\
\hline
\end{tabular}

Individual-level OLS regression of ESS-based psychological outcomes on Church exposure. Outcome variables were standardized (z-scores). The basic controls are country and survey-wave fixed effects, individual characteristics (gender, age, and age squared) and basic geographic controls (agricultural suitability, absolute latitude, mean distance to the sea and average terrain ruggedness). Robust standard errors clustered at the regional level are reported in parentheses. 'No. regions': number of regions. $* \mathrm{P}<=0.05, * * \mathrm{P}<=0.025, * * * \mathrm{P}<=0.005$ (one-sided).

The results shown in Table 3 are robust in several ways. First, Table S4.1 explores the effects of including both additional regional and individual-level variables. At the regional level, these models include a battery of geographic, climatic and agricultural controls as well as variables that capture a region's integration into the Roman Empire (based on Roman roads), population density in 500 CE (to capture economic development at the onset of the MFP), and incorporation within either the Carolingian Empire (814 CE) or the Soviet Bloc (1948 CE). These controls mitigate concerns that the Church may have been strategically moving along Roman roads or into ecologically or economically well-endowed regions. We also confirmed that these results hold after controlling for the presence of monasteries within each region and for the educational attainment at the individual level, which is important since the Church could be operating on contemporary psychology through its influence on schooling or monasteries instead of via kin-based institutions. Across 44 models, all of the coefficients on regional Church exposure are in the predicted direction and 42 are significant. Second, the results are robust to estimating the models using only the 191 regions in the formerly socialist countries of Europe (Figure 2 and Table S.4.2), which confirms our broader findings in a part of Europe with a very different history than Western Europe. Third, to verify that nothing hinges on the $100 \mathrm{~km}$ circle of influence we drew around each bishopric to define our regional Church exposure measure, we re-calculated it by assuming radii ranging from $50 \mathrm{~km}$ to $200 \mathrm{~km}$. Table S4.3 demonstrates that our results do not hinge on the choice of $100 \mathrm{~km}$. Furthermore, to address concerns that our baseline regional Church exposure measure may give too much weight to unpopulated pixels within a region, we constructed a population-weighted measure (Supplementary 2.3) and verified that our results are robust to using that measure.

To examine the relationship between intensive kin-based institutions and our four psychological outcomes, we turn to our sample of marriage rates among first cousins from Italy, Spain and France. Here, to highlight the uniform impact of intensive kinship across diverse populations with quite different histories, we augmented this data with first cousin marriage rates from Turkey. As the bridge between Europe and the Middle East, Turkey is interesting because it was never under the Western Church, so rates of cousin marriage remain much higher than in Europe. Figure 7 shows the relationship between cousin marriage rates and our four psychological outcomes. These relationships are all in the expected direction and strong, with cousin marriage accounting for between $27 \%$ and $69 \%$ of the psychological variation. 

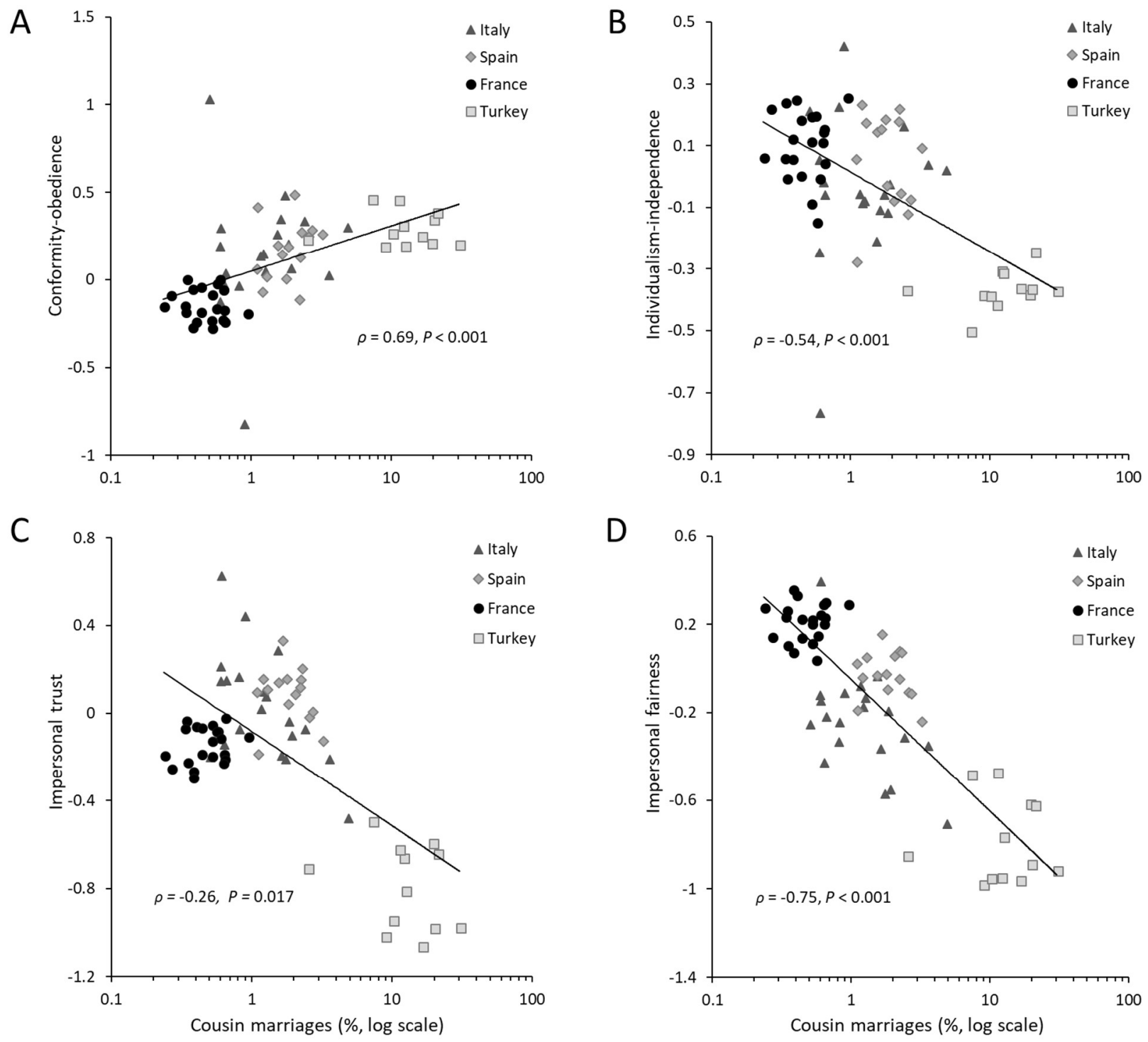

Figure 7. Relationships between regional estimates of cousin marriage and (A) conformity-obedience, (B) individualism-independence, $(C)$ impersonal trust (based on generalized trust) and (D) impersonal fairness (based on generalized fairness). In each panel, solid linear best-fit lines are displayed. Reported are Spearman's $\rho$ and associated significance levels (one-sided). The shape of each data point indicates the corresponding region's country (see legend).

To further explore these relationships, we regressed each of our four psychological outcomes on rates of cousin marriage across ten additional specifications (Table S4.5), following the same approach used for linking Church exposure to our psychological outcomes, albeit now with a smaller sample. For generalized trust and fairness, the coefficients on cousin marriage were always in the predicted direction and significant at the $5 \%$ level (one-sided test) in 18 of 20 specifications. The two specifications showing non-significant coefficients control for presence of the Carolingian Empire and the density of monasteries. This is not surprising given the role of both Carolingian rule and the monastic orders in implementing the MFP. For the other two psychological outcomes, 17 of the 18 coefficients on the rate of cousin marriage go in the predicted direction, though they are not estimated with precision. The loss in precision is due to the inclusion of country fixed effects since most of the variation in cousin marriage occurs between countries. 
As a final check, instead of using Church exposure, we looked at whether a region was in the Carolingian Empire in $814 \mathrm{CE}$, the year of Charlemagne's death. In the $8^{\text {th }}$ century, the Carolingian rulers teamed up with the Church to enforce the MFP. Consistent with this, we find that, within countries, regions exposed to the Carolingian Empire exhibit lower $20^{\text {th }}$ century cousin marriage and reveal greater individualismindependence, less conformity-obedience and both greater generalized trust and fairness. (Table S4.4 and Table S4.6).

Zooming in on Italy, where we have more finely grained cousin marriage data for 92 provinces, we examined voluntary, unpaid blood donations (Figure S5.1). In a simple regression, cousin marriage rates explain about a third of the variation in provincial blood donations. A doubling of the rate of cousin marriages is associated with a reduction in blood donations of about 8 bags per 1000 people (Figure S5.2). This is substantial given the mean donation across provinces is 28 bags per 1000 people. This effect either holds or increases when our geographic and ecological controls are included in the model, as well as when differences in formal schooling across provinces are controlled for (Table S5.1). This relationship is also robust to adding regional fixed effects as well as controls for the historical Kingdoms of Naples and Sicily, so we are not simply capturing a North-South difference. These patterns converge with other recent analyses linking cousin marriage rates in Italy to voter turnout, judicial efficiency, mafia activity and corruption at the provincial level $(115,116)$. As with UN diplomatic tickets and blood donations in our cross-country analyses, these results establish a real-world complement to the survey-based measures.

Finally, confirming the link between Church exposure and kinship intensity, Table S4.6 shows that Church exposure explains about $75 \%$ of the variation in cousin marriage across the regions of Turkey, Spain, France, and Italy. If Turkey is dropped, Church exposure still captures about $37 \%$ of the variation in cousin marriage. The association between Church exposure and cousin marriage holds when we compare only regions within countries and when controlling for a wide range of geographic and ecological variables as well as our measures of Roman roads and population density in $500 \mathrm{CE}$.

\section{The children of immigrants}

For native-born European adults whose parents immigrated into Europe from around the globe - secondgeneration immigrants - we linked the same four survey-based psychological measures used in the previous section to the KII, cousin marriage, and Church exposure of their parents' countries of origin (Supplementary 6). Then, by regressing each outcome on these measures of kinship intensity and Church exposure while controlling for resident-country fixed effects, we effectively compared only individuals who grew up in the same country. By analyzing the psychological impact of kin-based institutions only through second-generation immigrants, we can exclude the causal influence of all factors except those operating through some form of inter-generational transmission; this eliminates many alternative causal pathways that might be responsible for the relationships documented above.

Table 4 summarizes our baseline models, which link each respondent to his/her mother's native country, and individual-level demographics and both residence-country and wave fixed effects. The models also include our basic set of four geographic controls for the mother's native country. All 12 of the key coefficients go in the predicted direction, with less intensive kinship associated with a WEIRDer psychology, and are significant. Given that we are comparing only native-born Europeans from the same country based on the originating countries of their mothers, the effects are large. For example, a onestandard-deviation increase in the KII is associated with a change of between $7 \%$ to $13 \%$ of a standard deviation across our four psychological measures. Similarly, an additional millennium under the Western Church is associated with a change of between $15 \%$ and $28 \%$ of a standard deviation across our four psychological measures. 
Table 4. The children of immigrants in Europe. Regression of psychological outcomes on the KII, cousin marriage and Church exposure

\begin{tabular}{ccccc}
\hline \hline Variables & $\begin{array}{c}\text { Individualism- } \\
\text { independence }\end{array}$ & $\begin{array}{c}\text { Conformity- } \\
\text { Obedience }\end{array}$ & $\begin{array}{c}\text { Generalized } \\
\text { trust }\end{array}$ & $\begin{array}{c}\text { Generalized } \\
\text { fairness }\end{array}$ \\
KII of mother's o. country & $-0.068^{* *}$ & $0.127^{* * *}$ & $-0.097^{* * *}$ & $-0.079^{* * *}$ \\
N & $(0.028)$ & $(0.030)$ & $(0.014)$ & $(0.013)$ \\
R2 & 11,694 & 11,694 & 12,798 & 12,739 \\
Cousin marriage of mother's & 0.058 & 0.136 & 0.098 & 0.084 \\
o. country $(\%$, log) & $-0.063^{* * *}$ & $0.092^{* * *}$ & $-0.073^{* * *}$ & $-0.078^{* * *}$ \\
N & $(0.013)$ & $(0.016)$ & $(0.012)$ & $(0.009)$ \\
R2 & 6,875 & 6,875 & 7,508 & 7,484 \\
Western Church exposure & 0.059 & 0.131 & 0.101 & 0.089 \\
of mothers o. country & $0.018^{* *}$ & $-0.028^{* * *}$ & $0.019^{* * *}$ & $0.015^{* *}$ \\
Eastern Church exposure & $(0.007)$ & $(0.008)$ & $(0.006)$ & $(0.006)$ \\
of mothers o. country & $0.031^{* *}$ & $-0.056^{* * *}$ & $0.028^{*}$ & 0.006 \\
N & $(0.011)$ & $(0.011)$ & $(0.014)$ & $(0.011)$ \\
R2 & 11,347 & 11,347 & 12,415 & 12,360 \\
\hline \hline
\end{tabular}

OLS regressions of our four ESS-based dependent variables on (mother's origin country's) KII, log percent cousin marriage, and Western and Eastern Church exposure (in 100 years). Each column contains results from three separate regressions. An observation is a respondent with an immigrant mother. All regressions control for standard demographic variables (age, age squared, gender), as well as ESS wave, residence-country fixed effects and a set of origin-country controls (absolute latitude, ruggedness, caloric suitability for agriculture and mean distance to waterways). Robust standard errors clustered at the resident-country level are reported in parentheses. ${ }^{*} \mathrm{p}<0.05, * * \mathrm{p}<0.025, * * * \mathrm{p}<0.005$ (one-sided).

Table 4's results are robust to five checks. First, additional controls: to these baseline models, we added continental fixed effects for the mother's originating country, religious denomination and religiosity and a slate of other individual variables, including marital status, educational attainment, employment and feelings of discrimination (Table S6.1). Second, alternative ancestral linking: instead of using the mother's native country to assign the KII and cousin marriage prevalence variables to respondents, we re-estimated our main regressions using either the father's country of origin (Table S6.2) or the average of both parents' (Table S6.3). Third, two-way clustering: we clustered our standard errors at the level of both country of residence and mother's country of origin (Table S6.4). Fourth, regional and community size fixed effects (e.g., big city, suburb, farm, etc.): this allowed us to effectively compare only individuals living in the same subnational regions and in similarly sized communities (Table S6.5). Fifth, ancestral links via language: instead of assigning the KII via parental countries of origin, we matched second-generation immigrants to the KII via the languages they reported speaking in their homes (Table S6.7). This allowed us to also include country-of-origin fixed effects (in addition to residence-country fixed effects) in the regressions, and thus to narrow comparisons to people who not only live in the same countries but whose parents came from the same country (but from different ethno-linguistic groups). These supplemental analyses all broadly support the results shown in Table 4.

\section{Discussion}

To begin to explain the psychological differences now documented around the globe, we have proposed a two-part theory. First, we hypothesize that, in adapting to the social worlds created by intensive kin-based institutions, human psychology shifts in ways that foster greater conformity, obedience and sensitivity to relational contexts but less individualism, analytic thinking and cooperation with strangers. Second, to account for part of the variation in kinship intensity, we hypothesize that Western Christianity, beginning around $500 \mathrm{CE}$, gradually implemented a set of policies about marriage and the family - the MFP - that was a critical contributor to the eventual dissolution of the intensive kin-based institutions of Europe. By $1500 \mathrm{CE}$, this left many regions of Western Europe dominated by independent, monogamous, nuclear families - a peculiar configuration called the European Marriage Pattern $(54,55,97)$. This two-part theory 
implies that the Church, through the MFP, inadvertently contributed to what psychologists have termed WEIRD psychology.

We tested these hypotheses at three levels of analysis. Across countries, our analyses of 16 variables confirm that populations with less intensive kin-based institutions historically are psychologically WEIRDer today: they are more individualistic and independent but less nepotistic, conformist, obedient and holistically-oriented. Socially, populations with weaker kin-based institutions reveal less in-group loyalty, diminished moral particularism and greater trust, fairness and cooperation with strangers. Then, zooming in on Europe, by tracking the diffusion of the MFP from 550 to $1500 \mathrm{CE}$, we show that the longer a regional population was exposed to the Church, the higher their measures of individualism-independence and generalized trust and fairness and the lower their measure of conformity-obedience. Then, by tapping remnants of intensive kinship in Western Europe, we demonstrate that greater exposure to the Church is associated with less cousin marriage in the $20^{\text {th }}$ century, which in turn is associated with stronger individualism, less conformity and greater impersonal prosociality. In Italy, we further demonstrate that higher rates of cousin marriage are associated with fewer voluntary blood donations (a public good). Lastly, by linking second-generation immigrants in Europe back to the places where their parents originated, we demonstrate that the influence of both intensive kinship and Church exposure can still be detected psychologically among the adult children of immigrants living in the same European countries.

The psychological variation documented here may arise from the action of a combination of facultative, developmental and cultural-evolutionary mechanisms $(37,117-119)$ in response to the incentives created by intensive kin-based institutions. It is also possible that stable institutions may favor particular genetic variants that promote success within these institutional environments (120). Our empirical findings are largely agnostic regarding the relevance of these different mechanisms. However, the fact that we can detect the influence of historical kin-based institutions on psychology even decades after those institutions - as practiced on the ground-have disappeared suggests a role for inheritance, either cultural or genetic. But, the fact that we can relate psychological differences among European populations to relatively recent historical events like the MFP, suggests a central role for cultural transmission.

While our efforts lay a foundation that links psychological variation to kinship and kinship to the Church's MFP, more research is needed. Historical shocks or other natural experiments, for example, might be exploited to confirm the causal nature of these relationships. Additionally, archeo-genetic evidence may permit us to observe the impact of the MFP on patterns of relatedness over time in different parts of Medieval Europe while analyses of digitized corpora may allow us to track corresponding shifts in kinship (e.g., via kin terms) or on our psychology.

By integrating anthropological, psychological and historical evidence into a unified cultural evolutionary framework, our approach paves a new way of understanding contemporary behavioral variation. This is important because most efforts to understand human behavior presume either that little important psychological variation exists across populations or, if such variation does exists, that it represents merely shallow responses to current material incentives, governmental institutions or ecological conditions (121, 122). Our work, by contrast, suggests that contemporary psychological patterns, ranging from individualism and trust to conformity and analytic thinking, have been influenced by enduring family structures, particular religious practices and deep cultural evolutionary processes. Beyond their scientific interest, these insights may have broader implications since some of these psychological differences have previously been deployed to explain global variation in innovation (123-125), strength of formal institutions and corruption $(6,110,115,116,126)$ and economic prosperity $(16,123,124,127,128)$. 


\section{References and Notes}

1. J. Henrich, S. J. Heine, A. Norenzayan, The weirdest people in the world? Behav. Brain Sci. 33, 61$83(2010)$.

2. A. Falk et al., Global evidence on economic preferences. Q. J. Econ. (2018).

3. S. J. Heine, Cultural psychology (W. W. Norton \& Company, Inc., New York, Third edit., 2016).

4. A. Trompenaars, C. Hampden-Turner, Riding the waves of culture: understanding cultural diversity in global business (McGraw Hill, New York; London, ed. 2nd, 1998).

5. B. Herrmann, C. Thöni, S. Gächter, Antisocial punishment across societies. Science. 319, 13621367 (2008).

6. S. Gächter, J. F. Schulz, Intrinsic honesty and the prevalence of rule violations across societies. Nature. 531, 1-11 (2016).

7. I. Bohnet, F. Greig, B. Herrmann, R. Zeckhauser, Betrayal Aversion: Evidence from Brazil, China, Oman, Switzerland, Turkey, and the United States. Am. Econ. Rev. 98, 294-310 (2008).

8. S. Kitayama, H. Park, A. T. Sevincer, M. Karasawa, A. K. Uskul, A cultural task analysis of implicit independence: comparing North America, Western Europe, and East Asia. J. Pers. Soc. Psychol. 97, 236-55 (2009).

9. C. Kanagawa, S. E. Cross, H. R. Markus, "Who am I?" The cultural psychology of the conceptual self. Personal. Soc. Psychol. Bull. 27, 90-103 (2001).

10. K. R. Scherer, H. G. Wallbott, Evidence for universality and cultural variation of differential emotion response patterning. J. Personal. Soc. Psychol. 66, 310-328.

11. J. Haidt, J. Graham, When morality opposes justice: Conservatives have moral intuitions that liberals may not recognize. Soc. Justice Res. 20, 98-116 (2007).

12. R. Bond, P. B. Smith, Culture and conformity: a meta-analysis of studies using Asch's $(1952 b, 1956)$ line judgement task. Psychol. Bull. 119, 111-137 (1996).

13. T. Talhelm et al., Large-scale psychological differences within China explained by rice versus wheat agriculture. Science. 344, 603-608 (2014).

14. M. Schaller, D. R. Murray, Pathogens, personality, and culture: Disease prevalence predicts worldwide variability in sociosexuality, extraversion, and openness to experience. J. Pers. Soc. Psychol. 95, 212-221 (2008).

15. A. K. Uskul, S. Kitayama, R. E. Nisbett, Ecocultural basis of cognition: Farmers and fishermen are more holistic than herders (vol 105, pg 8552, 2008). Proc. Natl. Acad. Sci. U. S. A. 105, 8552-6 (2008).

16. G. Tabellini, Culture and institutions: Economic development in the regions of Europe. J. Eur. Econ. Assoc. 8, 677-716 (2010).

17. A. Greif, G. Tabellini, The clan and the city: Sustaining cooperation in China and Europe. J. Comp. 
Econ. 45, 1-35 (2015).

18. O. Galor, S. Michalopoulos, Evolution and the growth process: Natural selection of entrepreneurial traits. J. Econ. Theory. 147, 759-780 (2012).

19. N. Nunn, L. Wantchekon, The slave trade and the origins of Mistrust in Africa. Am. Econ. Rev. 101, 3221-3252 (2011).

20. E. Spolaore, R. Wacziarg, How Deep Are the Roots of Economic Development? J. Econ. Lit. 51, 325-369 (2013).

21. R. Fox, Kinship and marriage: an anthropological perspective (Penguin, Harmondsworth, 1967).

22. G. P. Murdock, Social structure (Free Press, New York, 1949).

23. D. Jones, The Matrilocal Tribe. Hum. Nat. 22, 177-200 (2011).

24. A. W. Johnson, T. K. Earle, The evolution of human societies: from foraging group to agrarian state (Stanford University Press, 2000).

25. K. Flannery, J. Marcus, The creation of inequality: How our prehistoric ancestors set the stage for monarchy, slavery, and empire. 41, 631 (2012).

26. M. Alvard, Kinship and cooperation. Hum. Nature-an Interdiscip. Biosoc. Perspect. 20, 394-416 (2009).

27. R. S. Walker, D. H. Bailey, Marrying kin in small-scale societies. Am. J. Hum. Biol. 26, 384-388 (2014).

28. D. H. Bailey, K. R. Hill, R. S. Walker, Fitness consequences of spousal relatedness in 46 small-scale societies. Biol. Lett. 10, 2-5 (2014).

29. B. Chapais, Primeval kinship: How pair-bonding gave birth to human society (Harvard University Press, 2009).

30. R. S. Walker et al., Living with kin in lowland horticultural societies. Curr. Anthropol. 54, 96-103 (2013).

31. C. L. Apicella, F. W. Marlowe, J. H. Fowler, N. A. Christakis, Social networks and cooperation in hunter-gatherers. Nature. 481, 497-501 (2012).

32. R. E. Nisbett, The geography of thought: How Asians and Westerners think differently...and why (The Free Press, New York, 2003).

33. R. E. Nisbett, K. Peng Choi, I., A. Norenzayan, Culture and systems of thought: Holistic vs. analytic cognition. Psychol. Rev. 108, 291-310 (2001).

34. J. Henrich et al., Market, religion, community size and the evolution of fairness and punishment. Science (80-. ). 327, 1480-1484 (2010).

35. M. Segall, D. Campbell, M. J. Herskovits, The influence of culture on visual perception (The BobbsMerrill Company, New York, 1966). 
36. S. C. Levinson, Kinship and human thought. Science (80-. ). 336, 988-989 (2012).

37. J. M. Clegg, N. J. Wen, C. H. Legare, Is non-conformity WEIRD? Cultural variation in adults' beliefs about children's competency and conformity. J. Exp. Psychol. Gen. 146, 428-441 (2017).

38. H. Witkin, J. Berry, Psychological differentiation in cross-cultural perspective. J. Cross. Cult. Psychol. (1975).

39. A. Alesina, P. Giuliano, Culture and institutions. J. Econ. Lit. (2015).

40. A. Alesina, P. Giuliano, in Handbook of Economic Growth (2014), vol. 2, pp. 177-215.

41. M. J. Gelfand et al., Differences between tight and loose cultures: A 33-nation study. Science (80-. ). 332, 1100-1104 (2011).

42. B. Enke, Kinship systems, cooperation and the evolution of culture. Dec 5 (2017).

43. J. Moscona, N. Nunn, J. A. Robinson, Keeping it in the family: lineage organization and the scope of trust in Sub-Saharan Africa (2017).

44. N. J. Wen, J. M. Clegg, C. H. Legare, Smart conformists: Children and adolescents associate conformity with intelligence across cultures. Child Dev. 00, 1-13 (2017).

45. M. Mitterauer, in Populations, connections, droits fondamentaux: mélanges pour Jean-Paul Lehners, T. Kolnberger, N. Franz, P. Péporté, Eds. (Mandelbaum Verlag, 2015), pp. 37-60.

46. M. Mitterauer, Kontrastierende Heiratsregeln: Traditionen des Orients und Europas im interkulturellen Vergleich. Hist. Sozialkd. 41, 4-16 (2011).

47. M. Mitterauer, Why Europe?: the medieval origins of its special path (University of Chicago Press, Chicago, 2010).

48. F. Fukuyama, The origins of political order: From prehuman times to the French Revolution (Farrar, Straus and Giroux, New York, ed. 1st, 2011).

49. J. Goody, The development of the family and marriage in Europe (Cambridge University Press, 1983).

50. A. Greif, Family structure, institutions, and growth: The origins and implications of western corporations. Am. Econ. Rev. 96, 308-312 (2006).

51. A. Greif, G. Tabellini, Cultural and institutional bifurcation: China and Europe compared. Am. Econ. Rev. 100, 135-140 (2010).

52. K. Ubl, Inzestverbot und Gesetzgebung. Die Konstruktion eines Verbrechens (300-1100) (Walter de Gruyter, Berlin, 2008).

53. A. Macfarlane, The origins of English individualism: the family, property and social transition (Blackwell, Oxford, 1978).

54. G. Clark, A farewell to alms (Princeton University Press, Princeton, N.J, 2007). 
55. P. Laslett, The world we have lost: further explored (Scribner, New York, ed. 3rd, 1984).

56. E. Todd, Explanation of ideology: Family structure \& social system (Blackwell, 1985).

57. A. Greif, On the history of the institutional foundations of impersonal exchange. J. Econ. Hist. 63, 555 (2003).

58. C. Lévi-Strauss, The elementary structures of kinship (Beacon Press, Boston, Rev., 1969).

59. J. Henrich, The secret of our success: How culture is driving human evolution, domesticating our species, and making us smart (Princeton University Press, Princeton, 2016).

60. J. Henrich, R. Boyd, P. J. Richerson, The puzzle of monogamous marriage. Phil. Trans. R. Soc. B. 367, 657-669 (2012).

61. R. A. McNamara, J. Henrich, Kin and kinship psychology both influence cooperative coordination in Yasawa, Fiji. Evol. Hum. Behav. 38, 197-207 (2017).

62. M. Alvard, Genetic and cultural kinship among the Lamaleran whale hunters. Hum. Nat. 22, 89107 (2011).

63. L. R. Binford, Constructing frames of reference: an analytical method for archaeological theory building using ethnographic and environmental data sets. Univ. California, Berkeley (2001).

64. H. S. Kaplan, P. L. Hooper, M. Gurven, The evolutionary and ecological roots of human social organization. Philos. Trans. R. Soc. B Biol. Sci., in press, doi:10.1098/rstb.2009.0115.

65. P. Wiessner, Hunting, healing, and hxaro exchange: A long-term perspective on! Kung (Ju/'hoansi) large-game hunting. Evol. Hum. Behav. 23, 407-436 (2002).

66. P. Wiessner, On network analysis: The potential for understanding (and misunderstanding)!Kung Hxaro. Curr. Anthropol. 39, 514-517 (1998).

67. L. Marshall, Marriage among !Kung bushmen. Africa (Lond). 29, 335-365 (1959).

68. P. Wiessner, Kung San networks in a generational perspective. past Futur. (1986).

69. G. K. Dow, L. Mitchell, C. G. Reed, The economics of early warfare over land. J. Dev. Econ. 127, 297-305 (2017).

70. S. Bowles, J. K. Choi, Coevolution of farming and private property during the early Holocene. Proc. Natl. Acad. Sci. U. S. A. 110, 8830-8835 (2013).

71. J. M. Diamond, Guns, germs, and steel: the fates of human societies (W.W. Norton \& Co, 1997).

72. K. R. Hill et al., Co-residence patterns in hunter-gatherer societies show unique human social structure. Science. 331, 1286-9 (2011).

73. S. Kitayama, J. Park, Cultural neuroscience of the self: understanding the social grounding of the brain. Soc. Cogn. Affect. Neurosci. 5, 111-129 (2010).

74. S. Kitayama, K. Ishii, T. Imada, K. Takemura, J. Ramaswamy, Voluntary settlement and the spirit 
of independence: evidence from Japan's "Northern frontier”. J. Pers. Soc. Psychol. 91, 369-384 (2006).

75. S. Kitayama et al., Reduced orbitofrontal cortical volume is associated with interdependent selfconstrual. Proc. Natl. Acad. Sci. 114, 201704831 (2017).

76. J. Henrich, Culture and social behavior (McGraw-Hill, New York, 1994).

77. D. G. Rand, S. Arbesman, N. A. Christakis, Dynamic Social Networks Promote Cooperation in Experiments with Humans. Proc. Natl. Acad. Sci. U. S. A. 108, 19193-19198 (2011).

78. J. H. Fowler, N. A. Christakis, Cooperative Behavior Cascades in Human Social Networks (2009), doi:10.1073/pnas.0913149107.

79. M. O. Jackson, T. Rodriguez-Barraquer, X. Tan, Social capital and social quilts: Network patterns of favour exchange. Am. Econ. Rev. 102, 1-45 (2012).

80. Y. Miyamoto, R. E. Nisbett, T. Masuda, Culture and the physical environment: Holistic versus analytic perceptual affordances. Psychol. Sci. 17, 113-119 (2006).

81. S. G. Goto, Y. Ando, C. Huang, A. Yee, R. S. Lewis, Cultural differences in the visual processing of meaning: detecting incongruities between background and foreground objects using the N400. Soc. Cogn. Affect. Neurosci. 5, 242-53 (2010).

82. T. Masuda, R. E. Nisbett, Attending holistically versus analytically: Comparing the context sensitivity of Japanese and Americans. J. Pers. Soc. Psychol. 81 (2001).

83. A. Norenzayan et al., The Cultural evolution of Prosocial Religions. Behav. Brain Sci. 39, 1-86 (2016).

84. W. H. McNeil, The Rise of the West: A History of the Human Community (University of Chicago Press, Chicago, 1991).

85. G. Ausenda, in The Visigoths from the migration period to the seventh century: an ethnographic perspective, P. Heather, Ed. (The Boydell Press, Woodbridge, 1999), pp. 129-190.

86. M. C. Ross, Concubinage in Anglo-Saxon England. Past Present, 3-34 (1985).

87. R. T. Anderson, Changing kinship in Europe (University of California, Berkeley, 1956).

88. H. J. Berman, Law and revolution: the formation of the Western legal tradition (Harvard University Press, Cambridge, Mass., 1983).

89. T. M. Charles-Edwards, Kinship, status and the origins of the hide. Past Present, 3-33 (1972).

90. A. Greif, Institutions and the path to the modern economy: Lessons from medieval trade (Cambridge University Press, New York, 2006).

91. P. J. Heather, The Visigoths from the migration period to the seventh century: an ethnographic perspective (Boydell Press, Woodbridge, 1999).

92. R. M. Karras, Concubinage and slavery in the Viking age. Scand. Stud. 62, 141-162 (1990). 
93. J. Witte, The Western case for monogamy over polygamy (Cambridge University Press, Cambridge, UK, 2015).

94. D. Herlihy, Medieval households (Harvard University Press, Cambridge, Mass., 1985).

95. D. D’Avray, Review article: Kinship and religion in the early Middle Ages. Early Mediev. Eur. 20, 195-212 (2012).

96. J. L. van Zanden, T. de Moor, Girl power: the European marriage pattern and labour markets in the North Sea region in the late medieval and early modern period 1. 1, 1-33 (2010).

97. J. Hajnal, Two kinds of preindustrial household formation system. Popul. Dev. Rev. 8, 449-494 (1982).

98. R. B. Ekelund, R. Hebert, R. D. Tollison, G. M. Anderson, A. B. Davidson, Sacred trust: the medieval church as an economic firm (Oxford University Press, New York, 1996).

99. G. P. Murdock, Ethnographic Atlas. Ethnology. 6, 109-236 (1967).

100. K. R. Kirby et al., D-PLACE: A Global Database of Cultural, Linguistic and Environmental Diversity. PLoS One. 11, e0158391 (2016).

101. M. P. Lewis, Ethnologue: Languages of the World (SIL International, Dallas, Texas, ed. 16, 2009).

102. A. H. Bittles, M. L. Black, Consanguinity, human evolution, and complex diseases. Proc. Natl. Acad. Sci. 107, 1779-1786 (2010).

103. K. L. Reyerson, in The New Cambridge Medieval History V, D. Abulafia, Ed. (Cambridge University Press, 1999), pp. 50-70.

104. C. Thöni, in Social dilemmas: New perspectives on trust (2016), pp. 1-19.

105. G. Hofstede, Culture's consequences: Comparing values, behaviors, institutions, and organizations across nations (Sage, Thousand Oaks, CA, 2001).

106. T. Talhelm, J. Graham, J. Haidt, “The budding collectivism revolution.” (Cambridge, MA, 2017).

107. S. E. Asch, Effects of group pressure on the modification and distortion of judgments (1951).

108. E. Van de Vliert, Climato-economic habitats support patterns of human needs, stresses, and freedoms. Behav. Brain Sci. 36, 465-480 (2013).

109. A. Trompenaars, C. Hampden-Turner, Riding the waves of culture: understanding cultural diversity in global business (McGraw Hill, New York; London, ed. 2nd, 1998).

110. R. Fisman, E. Miguel, Corruption, norms, and legal enforcement: evidence from diplomatic parking tickets. J. Polit. Econ. 115, 1020-1048 (2007).

111. L. Guiso, P. Spanienza, L. Zingales, The role of social capital in financial development. Am. Econ. Rev. 94, 526-556 (2004).

112. Inglehart, R. et al., World Values Survey: All Rounds - Country-Pooled Datafile (2014). 
113. NSD - Norwegian Centre for Research Data, Norway - Data Archive and distributor of ESS data for ESS ERIC. (2014).

114. T. G. Conley, GMM estimation with cross sectional dependence. J. Econom. 92, 1-45 (1999).

115. M. Akbari, D. Bahrami-Rad, E. O. Kimbrough, "Kinship, fractionalization and corruption," SSRN (2847222, 2016).

116. J. F. Schulz, "Why Europe? The Church, Kin-Networks and Institutional Development (Nov)" (2017).

117. B. R. House et al., Ontogeny of prosocial behavior across diverse societies. Proc. Natl. Acad. Sci. 110, 14586-14591 (2013).

118. S. Oishi, T. Talhelm, Residential Mobility: What Psychological Research Reveals. Curr. Dir. Psychol. Sci. 21, 425-430 (2012).

119. S. Oishi, J. Schug, M. Yuki, J. Axt, in Handbook of Advances in Culture and Psychology (Oxford University, New York, Kindle Edi., 2015), vol. 5, pp. 221-272.

120. P. J. Richerson, R. Boyd, J. Henrich, Gene-culture coevolution in the age of genomics. Proc. Natl. Acad. Sci. U. S. A.

121. D. Acemoglu, J. Robinson, Why nations fail: the origins of power, prosperity, and poverty (Random House Digital, Inc., 2012).

122. C. L. Fincher, R. Thornhill, D. R. Murray, M. Schaller, Pathogen prevalence predicts human crosscultural variability in individualism/collectivism. Proc. Biol. Sci. 275, 1279-85 (2008).

123. Y. Gorodnichenko, G. Roland, Culture, institutions, and the wealth of nations. Rev. Econ. Stat. 99, 402-416 (2016).

124. Y. Gorodnichenko, G. Roland, Individualism, innovation, and long-run growth. Proc. Natl. Acad. Sci. U. S. A. (2011), doi:10.1073/pnas.1101933108.

125. J. Mokyr, A culture of growth: the origins of the modern economy (Princeton University Press, Princeton, 2016).

126. M. A. Woodley, E. Bell, Consanguinity as a major predictor of levels of democracy: a study of 70 nations. J. Cross. Cult. Psychol. 44, 263-280 (2012).

127. Y. Algan, P. Cahuc, Trust and growth. Annu. Rev. Econom. 5, 521-549 (2013).

128. Y. Algan, P. Cahuc, Inherited trust and growth. Am. Econ. Rev. 100, 2060-2092 (2010). 


\section{The Origins of WEIRD Psychology}

Jonathan Schulz, ${ }^{1 *}$ Duman Bahrami-Rad, ${ }^{2}$ Jonathan Beauchamp, ${ }^{3}$ and Joseph Henrich ${ }^{4 *}$

${ }^{1}$ Department of Human Evolutionary Biology, Harvard University.

${ }^{2}$ Department of Economics, Simon Fraser University.

${ }^{3}$ Department of Economics, University of Toronto.

${ }^{4}$ Department of Human Evolutionary Biology, Harvard University, and CIFAR.

*Correspondence to: jonathan.schulz77@gmail.com and joseph.henrich@gmail.com 
These Supplementary Materials are structured in four Parts. Part I provides background on kinship intensity and the indicators we constructed (Section S1) and on the Churches' Marriage and Family Program (MFP) (Section S2). Part II reports the empirical results. It begins with a brief overview of our overall empirical strategy and a discussion of potential endogeneity issues. Section S3 reports the results of the cross-country analysis; Section S4 reports the results of the European regional analysis; Section S5 reports the results of the analysis of Italian provinces; Section S6 reports the results of the epidemiological approach (which focuses on second-generation immigrants); and Section S7 reports the results of the analysis of ethnicities' ancestral kinship and psychological outcomes. Part III details how we used a methodological innovation to create country-level aggregates based on ethnicity-level measures from the Ethnographic Atlas (Section S8) and lists data sources for the dependent variables and covariates we analyze (Section S9). Part IV lists the references.

\section{CONTENTS}

Part I: Kinship Intensity and the Churches' Marriage and Family Program: Background and Measures ..........4

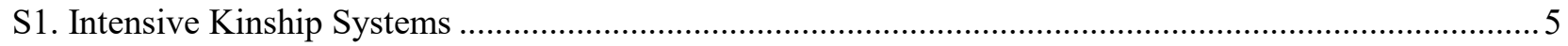

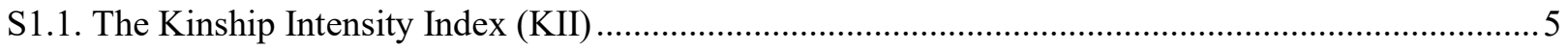

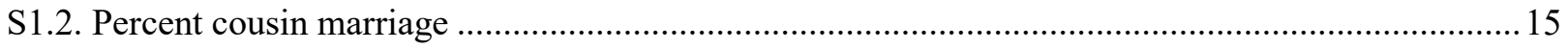

S2. The Churches' Marriage and Family Program .............................................................................. 18

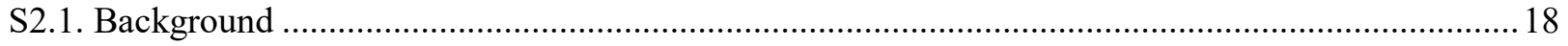

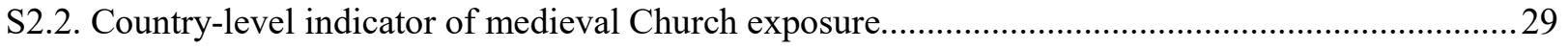

S2.3. Regional indicator of medieval Western Church exposure ........................................................ 36

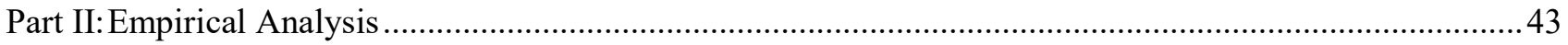

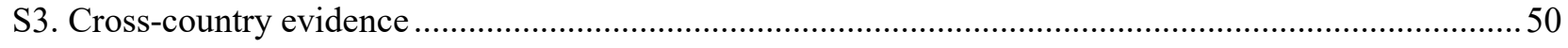

S3.1. Kinship intensity, medieval Church exposure and psychology ……...............................................50

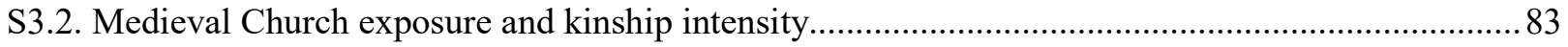

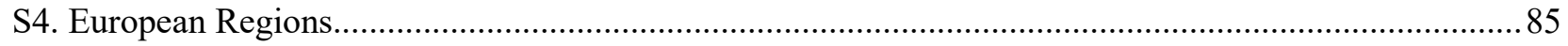

S4.1. Western Church exposure and psychology across European regions .......................................... 88

S4.2. The Carolingian Empire and contemporary psychology ...........................................................95

S4.3. Kinship intensity and psychology in regions of Spain, France, Italy and Turkey.......................... 98

S4.4. Church exposure, Carolingian Empire and kinship intensity .................................................. 101

S5. Kinship intensity in Italian provinces and blood donations .............................................................. 104

S6. Epidemiological approach: Children of immigrants in Europe ........................................................... 108

S6.1. Kinship intensity of the parents' country of origin and psychological outcomes ......................... 109

S6.2 Kinship intensity of ancestral ethnicity and psychological outcomes ........................................... 116

S7. Ethnicities' ancestral kinship intensity and psychology ...................................................................119

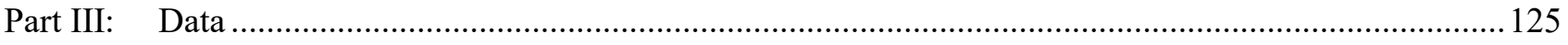


S8. Linking the Ethnographic Atlas to current countries of the world .................................................. 126

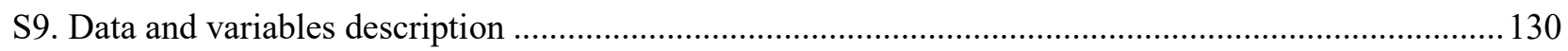

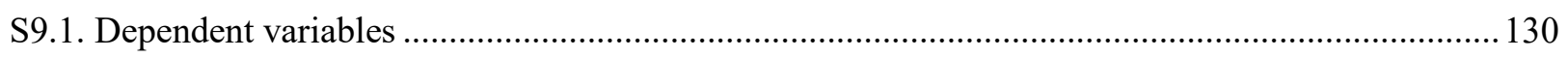

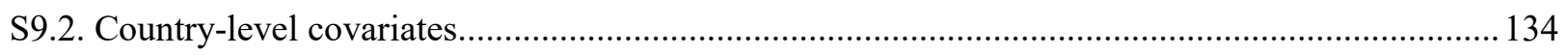

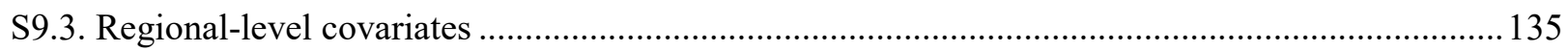

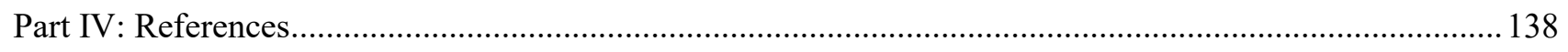




\section{Part I: Kinship Intensity and the Churches' Marriage and FAMILY PROGRAM: BACKGROUND AND MEASURES}

In this section we provide some background information and introduce our measures of kinship intensity (Section S1) and of exposure to the medieval Churches' Marriage and Family Program (MFP) (Section S2). 


\section{S1. Intensive Kinship Systems}

Human societies organize themselves in an immense diversity of ways, and over much of history and back into our evolutionary past these organizational structures have been built around core aspects of human kinship (1-23). In many parts of the world, these social structures involve extended kin-groups - which are variously characterized by the presence of kin and polygamous marriages, co-residence of extended families, and unilineal descent - that form an integral part of people's everyday lives. This contrasts with WEIRD societies (Western, Educated, Industrialized, Rich and Democratic (24)). In WEIRD societies, the social structure is characterized by a strong emphasis on the monogamous nuclear family, and descent is bilaterally traced through both the mother's and the father's side (25-27). Anthropologists have characterized differences in kin-structures along the dimension of extensive vs. intensive kinship systems (23). Intensive kinship emphasizes cultural practices like kin marriages, polygyny, endogamy, co-residence, unilineal descent and clan organizations, that weave dense and overlapping sets of network connections.

By contrast, more extensive kinship systems, such as those often found among mobile foragers, place a greater emphasis on building diverse, non-overlapping and broad relational ties. Extensive kinship systems entail marriage to partners from geographically distant communities. Marrying and residing with unrelated individuals creates a larger and more diverse social network. The implied more diverse networks and alliances with a larger number of affinal kin may have initially been more important for hunter gatherers. In an unpredictable environment, having kin in different places mitigates and hedges risks during times of scarcity or environmental shocks $(10-12,15,23,28)$. Since the Holocene began, the formation of intensive kinship systems may be a consequence of the demands created by certain form of food production ${ }^{1}$ and the need to control territory $(14,19,20)$. That is, dense and concentrated kin-networks may have provided a powerful means to defend resources. They may be particularly important in societies that undertake large investments (like building irrigation systems) or rely on movable property (like husbandry) since it is easier to steal. The development of kin-based institutions and eventual formation of pre-modern states is thus linked to ecological, climatic, and geographic factors that may have favored the emergence of food production $(29,30)$. Our approach here suggests that the Church's MFP broke the association between kinship intensity and intensive agricultural practices to a degree never achieved by prior non-kin-based institutions, including premodern states.

Our analyses rely on two main indicators to capture the degree of extensive vs. intensive kinship that characterizes a population: the Kinship Intensity Index (KII) and the percentage of cousin marriage. The following sections describe each indicator in detail. The former, based on anthropological reports, provides an omnibus measure that combines several elements common to intensive kin-based institutions while the latter provides an 'on-the-ground' statistical measure of one important aspect of intensive kinship, cousin marriage.

\section{S1.1. The Kinship Intensity Index (KII)}

The KII consists of five sub-indicators, all of which capture different aspects of kinship intensity: (1) preference for cousin marriage, (2) polygamy, (3) co-residence of extended families, (4) lineage organization,

\footnotetext{
${ }^{1}$ We use the expression "food production" to refer to agriculture and/or animal husbandry.
} 
and (5) community organization. The underlying data is taken from the Ethnographic Atlas (EA) in its extended versions as provided by the Database of Places, Language, Culture, and Environment (D-PLACE see www.d-place.org). The extended Ethnographic Atlas includes data on 1,291 ethnicities, which are mostly coded from ethnographies written by anthropologists (31-36). We excluded eight ethnicities, which were coded for pre-1500CE characteristics. The EA aims to reflect the characteristics of the ethnicities before European contact and the onset of the Industrial Revolution. In the following, we detail each of the five subindicators:

1. Cousin marriage preference. Marriage is a decisive element of social structure. Beyond merely tying together two spouses, marriage encourages the formation of alliances between families, clans, houses and kindreds. Many societies have created social norms prescribing preferences for, or taboos against, various types of kin-marriages. Kin-marriages impact social structure by increasing the density of social ties, forging stronger bonds (underwritten by genetic relatedness and common socialization). Cousin marriages reduce therefore the total number of affinal and genetic relatives and thereby increasing kinship intensity. Affines are genetically related: Rather than forming extensive ties with genetically unrelated affinal kin, affinal and genetic relatedness are therefore combined within the same person. This has consequences for socialization: blood relatives who marry each other have a similar socialization. For example, at least two of the four parents of a first-cousin marriage couple are siblings and were thus socialized in the same family while growing up. This may foster an in-group mentality and help guarantee that both the couple and their extended families share the same social norms and beliefs. Apart from socialization, the genetic implication is that the offspring of married cousins are more closely genetically related to their entire extend families compared to the offspring of non-cousin spouses. To the degree that evolutionarily shaped heuristics favor kin, cousin marriage may likewise impact behavior through the channel of kin-selection $(37,38)$.

The Ethnographic Atlas contains information on whether or not cousin marriage is preferred in a given society, and if so, what type is preferred (variable ea026 in the D-PLACE data set). We coded an (ordinal) sub-indicator, which takes the value of 0 if cousin marriage is not preferred in a society; 1 if second- (but not first-) cousin marriage is preferred; 2 if a cross-cousin marriage is preferred; and 3 if a parallel-cousin marriage is preferred. The coding is meant to capture something of the degree to which each of these practices promote intense, inward-looking, relationships. A parallel cousin is a cousin from a parent's same-sex sibling (e.g., one's father's brother's child), while a cross cousin is a cousin from a parent's opposite-sex sibling (e.g., one's father's sister's child). The important difference between the two is that in unilineal societies cross cousins do not belong to the same lineage, while parallel cousins do. For example, in patrilineal societies the parallel cousin marriage of a son to his father's brother's daughter leads to spouses who belong to the same lineage (in the EA all 44 ethnicities with parallel-cousin marriages are patrilineal). Thus, marriage does not reach out to another lineage, which increases kinship intensity further. Correspondingly, parallel cousin marriage gets a higher score in the KII.

The extended EA contains data on cousin marriage preference for 1,042 ethnicities. To enlarge the sample, we predicted cousin marriage preference based on cousin terms (see (39) for a similar approach). The relationship between kinship systems and kin-terms is foundational to Anthropology $(17,40)$. The 
rationale for this association is that kin-terms help to classify genealogically related individuals according to functional roles and communicative demands (41). For example, in a society where cross cousins (e.g., a man's father's sister's daughters) are the preferred marriage partners and parallel cousins (e.g., a man's father's brother's daughters) fall under an incest taboo, the two types of cousins are often called by different names. In those societies parallel cousins are frequently called "brothers" or "sisters", which underscores the incest taboo via kin-terms and highlights the functional role of kin-terms. The efficiency advantage of classifying relatives via kin-terms according to functional roles becomes apparent when one considers that the number of genealogically related individuals increases exponentially as one moves away from ego to more distant relatives. For example, in WEIRD societies where relatives are traced bilaterally there is most often only one term - cousin - for (i) mother's sister's offspring (ii) mother's brother's offspring (iii) father's sister's offspring (iv) father's brother's offspring (and one could differentiate further by relative age etc...). The EA contains data on cousin terms classified into eight categories (Crow, Descriptive, Eskimo, Hawaiian, Iroquois, Omaha, Sudanese, and Mixed).

To predict cousin marriage preference based on cousin terms, we first analyzed the sample of ethnicities with data on both cousin marriage preference and cousin terms. For each cousin term category, we calculated the mean of the cousin marriage sub-indicator. We used the resulting mean values to predict the expected cousin marriage preference sub-indicator based on cousin terms, for ethnicities where only data on cousin terms are available. ${ }^{2}$ This increases the sample by 93 ethnicities to a total of 1,135 observations.

Figure S1.1 displays the sub-indicator cousin marriage preference at the ethnicity level. In a novel method, we use data on language trees to computationally link pre-industrial ethnographic data from the Ethnographic Atlas to current populations (see the methodology in S.8).

\footnotetext{
${ }^{2}$ For ethnicities with data on both cousin marriage preference and cousin terms, the predicted cousin marriage subindicator is significantly correlated with the actual cousin marriage preference sub-indicator (Spearman's $\rho=0.39$, $\mathrm{N}=862, P<0.001$ ). While this correlation is not particularly high, unlike in this robustness check where we base all 783 observations on cousin-terms in the actual KII only 93 are based on these predictions. As a further robustness check we calculated how the KII at the ethnicity level correlates to one where cousin marriage preference is entirely calculated based on cousin terms (that is, substituting the sub-indicator cousin marriage preference with cousin-terms). Spearman's $\rho$ between those two indicators reveals a high correlation of $0.91, P<0.001, \mathrm{~N}=783$. The use of cousin-terms to predict cousin marriage preference thus will not change the KII in any major way.
} 


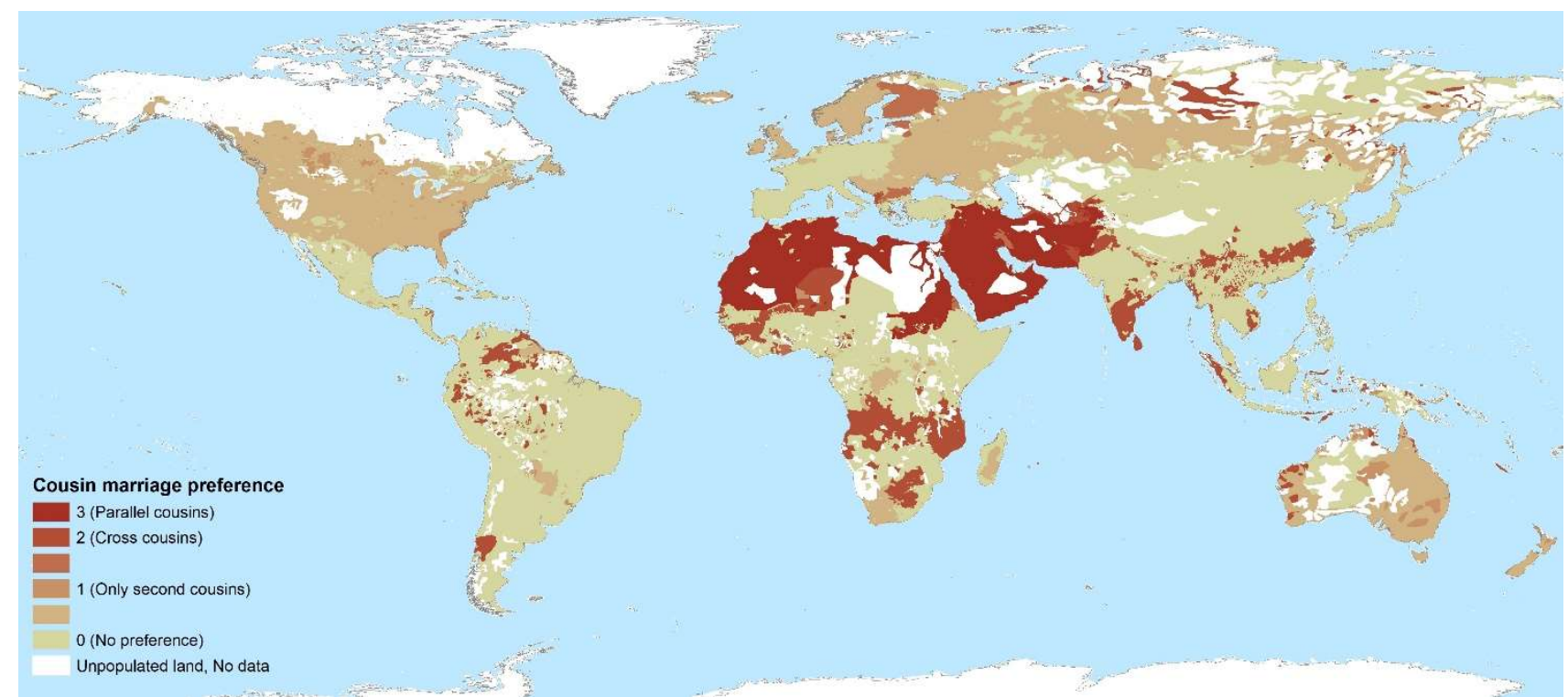

Figure S1.1 Ancestral cousin marriage preference across ethnic/language groups: 0-No preference; 1-Only second cousins; 2-Cross cousins; 3-Parallel cousins. Ethnicities with non-integer values (i) share a language with several societies in the Ethnographic Atlas that have different practices; (ii) have cousin marriage measures predicted by cousin terms; or (iii) a combination of both (see Section S8 for details).

2. Polygamy. In many societies around the world, polygamy (and especially polygyny) has been common (6). Polygamous marriage is an important determinant of kinship intensity. Like cousin marriage, it has genetic implications: polygamy introduces reproductive skew because fewer men reproduce (23) (23, 42). This increases genetic group relatedness. This genetic component, which fosters kinship intensity, is however only one aspect of polygamy relating to kinship intensity. Having sexual relations (and potentially offspring) with more than one partner is not the only important characteristic of polygamy. A hallmark of polygamous marriage is the formation of a common extended household. As such, apart from the increase in genetic relatedness, it also fosters cohesion as a consequence of co-residence: a larger number of genetically-related people cohabit together, thereby re-enforcing and strengthening kinship intensity. What is the impact of the excess of unmarried men for kinship intensity? Unmarried, they neither create extensive or intensive bonds through marriage and most often stay in their natal home keeping close ties with their extended family. Polygyny can impact psychology not only through increased kinship intensity but also through its implied intrasexual competition, which fosters crime and risk-raking (6). The prohibition of polygamous marriage is part of a larger package of marriage prohibitions that contributed to kinship intensity and a WEIRD psychology. We therefore include it in the KII. To address the channel that goes through risk-taking, violent or criminal activities, in robustness checks we demonstrate that the regression results hold when using an KII that excludes the polygamy sub-indicator and controls for it separately (see Table S3.11 in Section S3.1 in the cross-country analysis and Table S6.6 in Section S6.1 in the children of immigrants analysis). The EA (variable ea009 in the DPLACE data set) categorizes societies into monogamy (assigned score of 0), occasional or limited polygyny (assigned score of 1), and common polygyny (assigned score of 2). Four societies in the EA are coded as polyandrous. They are likewise ascribed a score of 2 in the polygamy sub-indicator. Figure S1.2 shows polygamy at the ethnicity-level. 


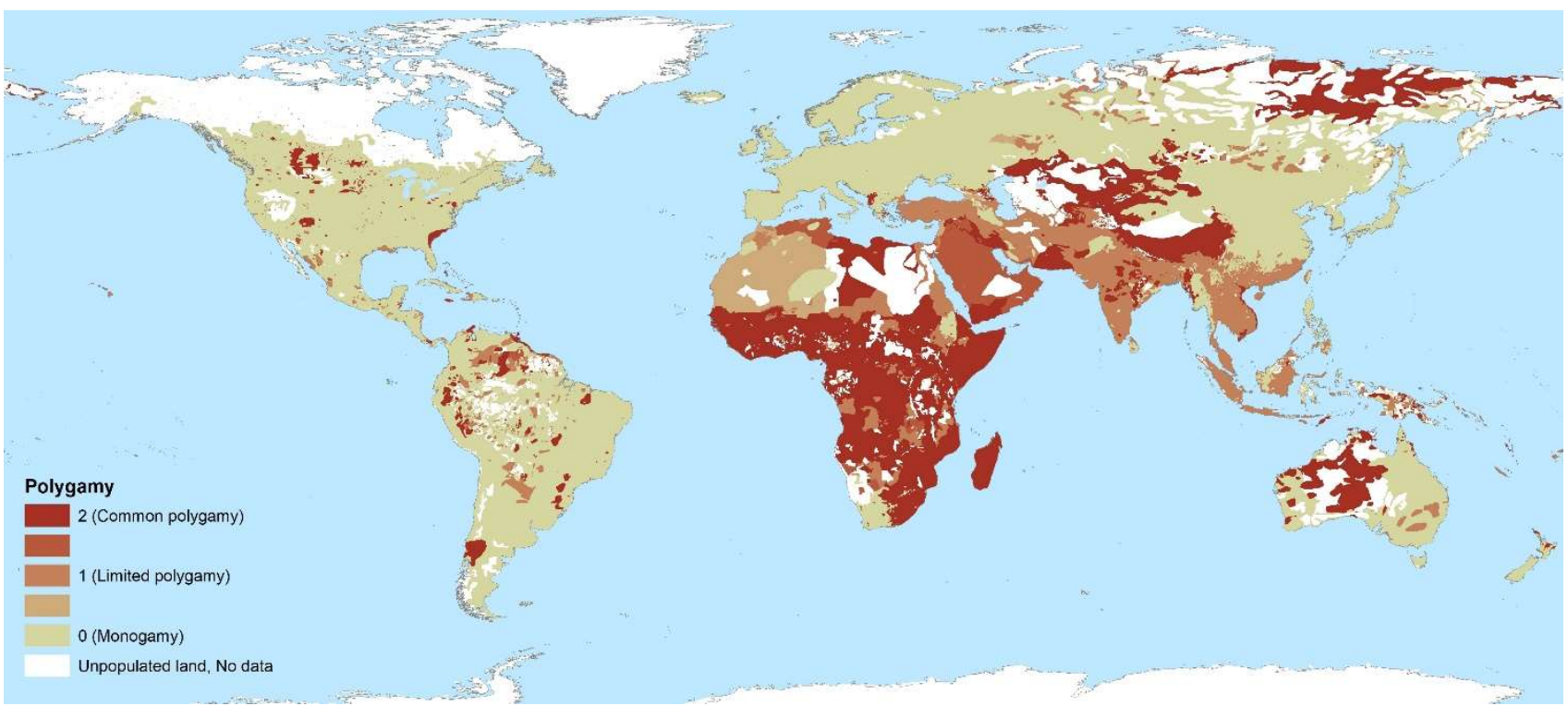

Figure S1.2 Ancestral polygamous tradition across ethnic/language groups: 0-Monogamy; 1-Limited polygyny, 2-common polygyny. Ethnicities with non-integer values share a language with several societies in the Ethnographic Atlas that have different practices.

3. Co-residence of extended families. An important dimension of intensive kinship systems is family type, as measured by how many generations of a family are localized (live in the same or adjacent houses). The nuclear family (prevalent in WEIRD societies) consists of parents and their children. An extended family is characterized by several generations, each with its own nuclear family, living under one roof. For example, this could be two parents with their adult children, who are likewise married and have children, all living together. The close proximity and more frequent interactions help foster stronger ties among family members, while at the same time interactions with non-related neighbors decrease. A decisive factor for the formation of extended families is marital residence rules. Extended families can only form when one spouse moves in with the family of the other. The alternative is that both spouses move to a new location (neo-locality), which precludes the formation of an extended family. The resulting family in this case is a nuclear one. At the new location, the members of the nuclear family will inevitably form ties with their neighbors and thereby build more extensive (rather than intensive) ties.

The EA contains two variables that capture this aspect of kinship. One is domestic organization (variable ea008 in D-PLACE). We created a variable that is coded 0 for "Independent nuclear / Independent polygamous families", 1 for "minimal extent or stem families", 2 for "small extended families" and 3 for "large extended families". The other relevant EA variable is marital residence (variable ea012 in DPLACE). We created a variable that takes the value 0 for "neo-locality", 1 for "ambilocality" (individuals can choose which side of the family they relocate to), and 2 for the remaining cases (e.g., "patrilocality", or "matrilocality"). Like patri- or matrilocality, ambilocality reveals co-residence (and hence whether extended families can form or not). However, the fact that the couple is allowed to relocate to either the father's or the mother's side reveals that kin-ties at the clan or lineage level are not particularly strong. It thus suggests lower kinship intensity compared to the unambiguous rule of either patrilocality or matrilocality. 


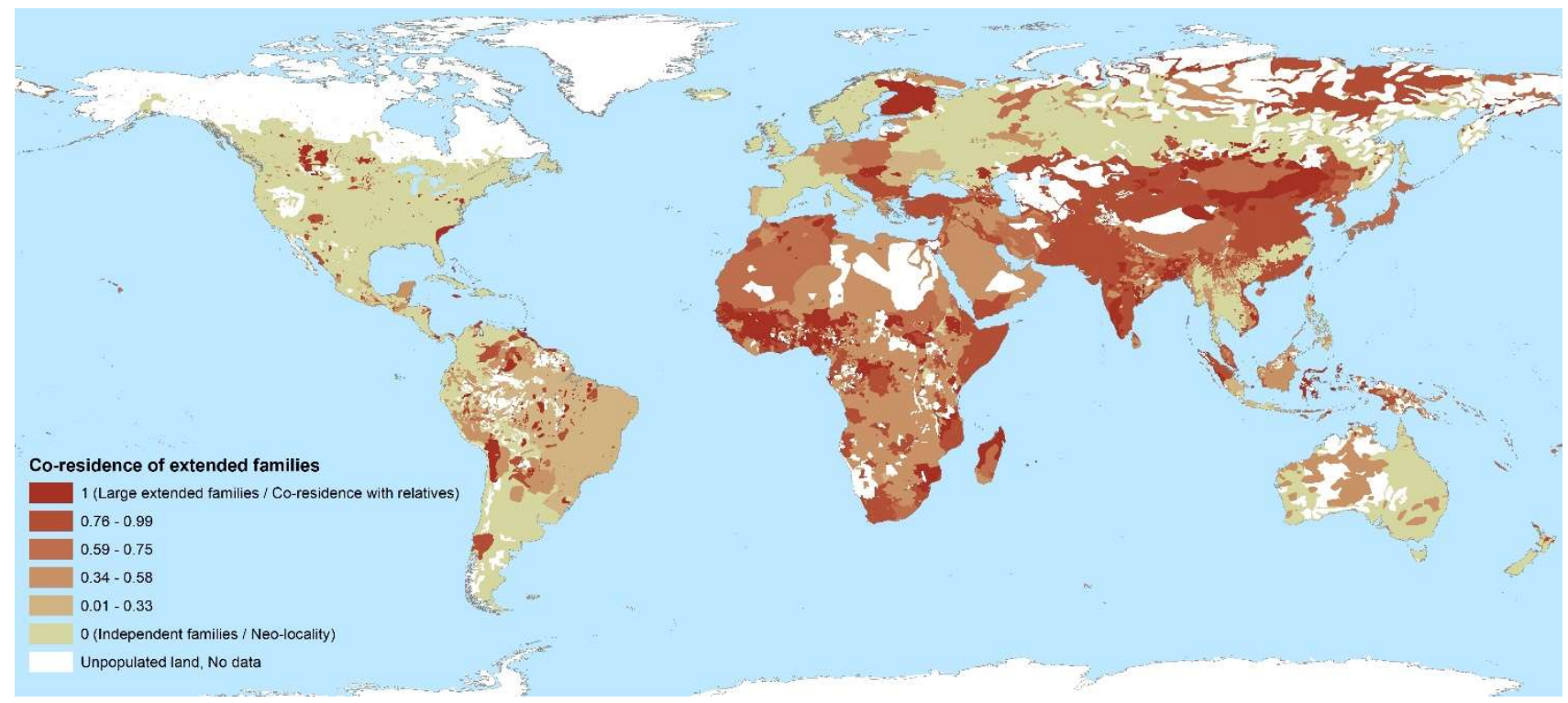

Figure S1.3 Ancestral co-residence of extended families across ethnic/language groups. A value of 0 reflects independent families with neo-local residence, while a value of 1 reflects large, co-residing, extended families.

By definition, neo-locality and co-residence of extended families are incompatible. Conceptually, thus, these two variables measure to a large degree the same underlying concept. $93 \%$ and $57 \%$ of ethnicities coded as neolocal and ambilocal, respectively, are also coded as independent nuclear or polygamous families. Surprisingly, $50 \%$ of matrilocal or patrilocal ethnicities are also coded as independent nuclear or independent polygamous. This inconsistency may be due to measurement error or to the implicit (numerical) cutoffs, which determine the ordinal categories, having been set differently for the two variables. For example, patri- or matrilocality of the EA variable "marital residence" may be referring to relocation to a community more broadly, while the defining criteria of co-residence for the domestic organization variable may be more narrowly referring to the same or adjunct houses.

We take the average of the domestic organization and marital residence variables to create the subindicator co-residency of extended families. Combining these two variables smooths discrepancies and should therefore give a better representation of the co-residency of extended families. In cases where the EA has information on only one of the two variables for an ethnicity, the sub-indicator is only based on the non-missing information. ${ }^{3}$ This approach increases the number of observations by 38 , to 1,284 ethnicities. Figure S1.3 reveals the strength and prevalence of extended families at the ethnicity level.

\footnotetext{
${ }^{3}$ We use the non-missing variable to predict the other (using a procedure akin to the one we used to predict cousin marriage based on cousin terms). Rather than giving the non-missing variable twice the weight, we use the prediction based on the conditional means to take account for the fact that the association between the two variables is not perfect.
} 
4. Lineage organization. Another important dimension of kinship intensity involves rules of descent. In unilineal societies, descent is traced through either the mother's line (matrilineal societies) or the father's line (patrilineal societies). The crucial characteristic of unilineal descent is that it is exclusive. A person can only belong to one lineage. Unilineal descent thus helps to structure family relations and to define non-conflicting rules and obligations. For example, such rules may dictate to which uncle one should turn to for help: one's mother's brother or one's father's brother? Or, if conflict arises, which side of the family is one obliged to support? At the other end of the spectrum of descent organization stand bilateral rules of descent, under which descent is traced through both the mother's and father's sides. This creates more equal network ties between both sides of the family and thus less fractionalization. The bilateral descent of WEIRD societies bases the same importance on the father's and mother's side. It is nonexclusive and as a result - and in contrast to unilineal descent systems - everyone except siblings has a unique combination of relatives, which leads to a more divers kin-network and therefore decreases kinship intensity. Fractionalization along lineages thus likewise leads to more kinship intensity.

Lineages are culturally-defined rules of descent; they are not necessarily defined by genetic relatedness or co-residence. One almost universal feature of unilineal descent is lineage exogamy. It may appear that this could offset the kinship intensity created by rules of unilineal descent, as lineage exogamy forces people to marry out; however, these marriages often follow additional restrictive rules - such as a strong preference for marrying cousins or community endogamy - and are thus part of an intensive kinship system. ${ }^{4}$ Importantly, anthropologists have argued that lineage exogamy itself is the result of strong within-lineage bonds $(13,17,43)$. First, forcing people to marry outside of the lineage may decrease male competition for women within the lineage. Secondly, evolutionarily evolved mechanisms against incest (e.g., not having sexual intercourse with the ones you grew up with) may have been activated due to high cohesion and co-residence within the lineages, thus favoring rules about lineage exogamy. Lineage exogamy is therefore likely a manifestation of strong cohesion within the lineage.

Based on variable ea043 in the EA, we coded the Lineage organization sub-indicator 0 for bilateral descent and 1 otherwise (apart from patrilineal and matrilineal, this category also contains the EA classifications duolateral, quasi-lineage and ambilineal descent). Figure S1.4 reveals worldwide ancestral lineage organization at the ethnicity level.

\footnotetext{
${ }^{4}$ There are instances where lineage exogamy might decrease kinship intensity: in Korea, for example, individuals were forbidden to marry others with the same surname because of lineage exogamy. Concentration of certain surnames forced individuals with those surnames to reach further to find a spouse, thus building more extensive kinship ties.
} 


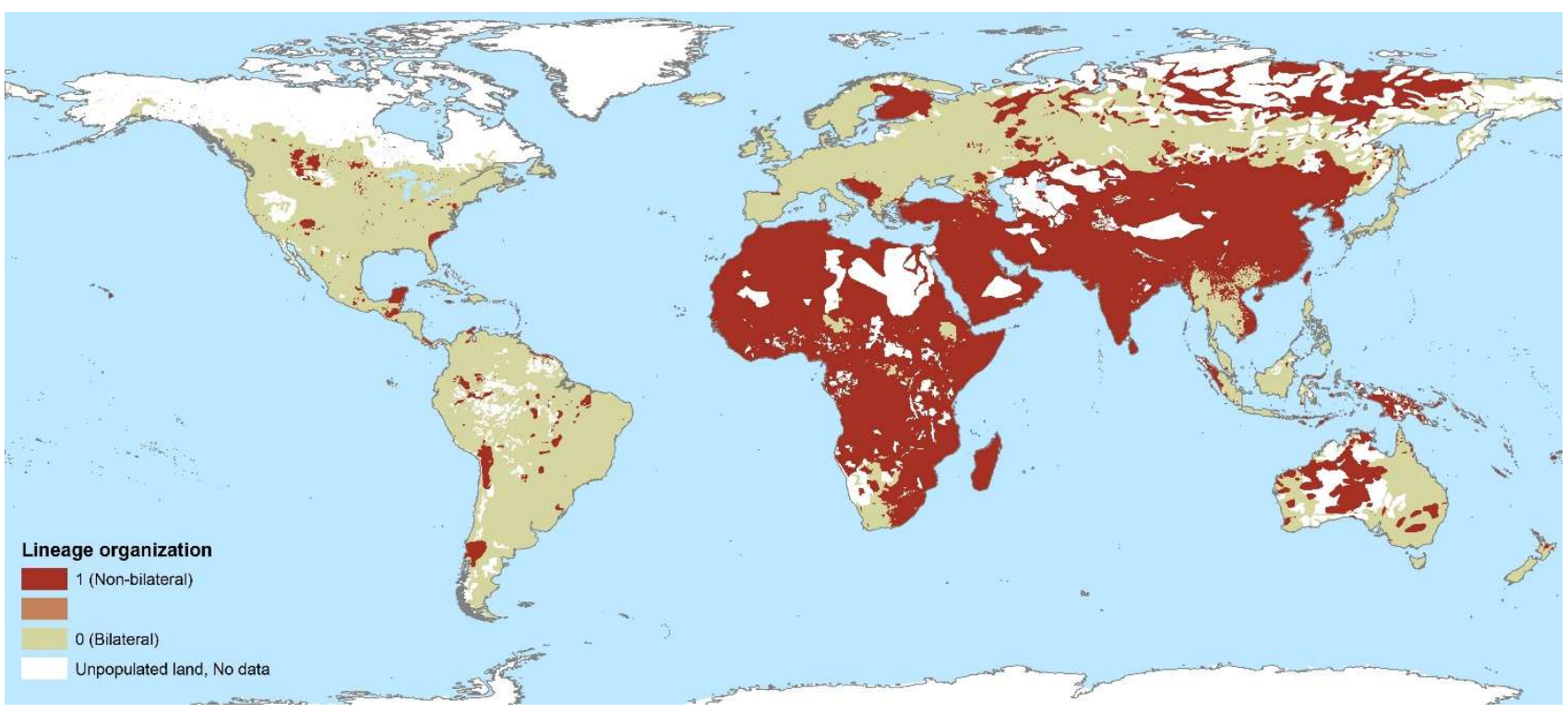

Figure S1.4 Ancestral lineage organization across ethnic/language groups: 0-Bilateral descent; 1-Non-bilateral descent. Ethnicities with non-integer values share a language with several societies in the Ethnographic Atlas that have different practices.

5. Community organization. Community organization varies along two sub-dimensions, which both have implications for kinship intensity. The first sub-dimension is whether communities contain localized clans or extended families. That is, this sub-dimension measures whether people belonging to an extended family or clan all reside in one specific (localized) area of the settlement. Clearly, localization of clans and extended families decreases the interaction with outsiders and thus contributes to kinship intensity. This is particularly apparent in cases in which the whole community just consists of one single clan. The second sub-dimension concerns marriage patterns and more precisely whether there is community-level endogamy. Endogamous communities form denser clusters since no outsiders from different villages join the community.

The sub-indicator community organization (based on the EA variable ea015) combines these two dimensions and takes the value of 1 if localized clans are present and/or if community endogamy exists. If both are absent, the variable takes the value 0 (this is the case for the two categories "Agamous communities without localized clans" and "Exogamous communities without clan structure"). A community organization value of 0 is thus typical of WEIRD communities that do not form localized groups and have no tendency towards local endogamy. Figure S1.5 gives an overview of the worldwide ethnicity-level distribution of community organization. 


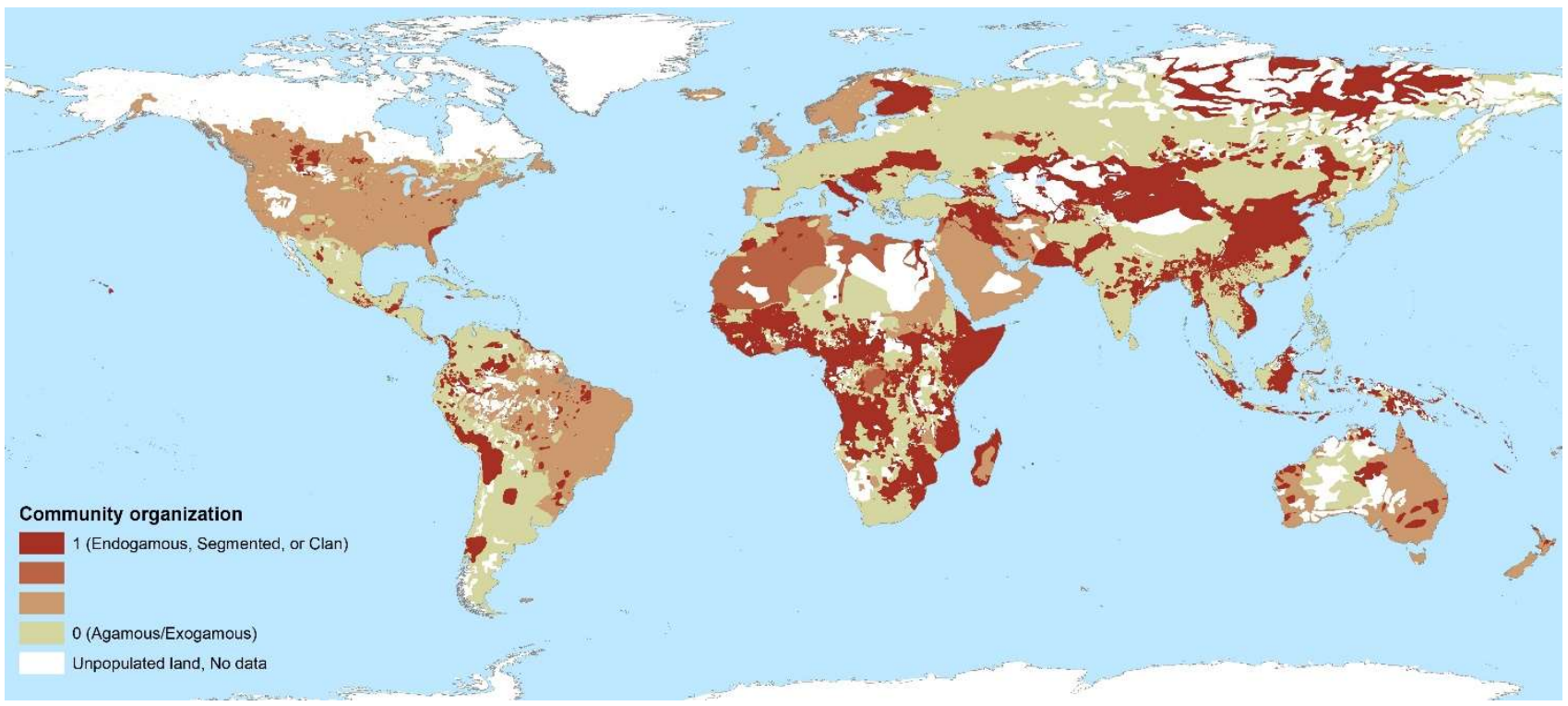

Figure S1.5 Ancestral community organization across ethnic/language groups: 0-Agamous or exogamous communities; 1-Clans, and segmented or endogamous communities. Ethnicities with non-integer values share a language with several societies in the Ethnographic Atlas that have different practices.

\section{The Kinship Intensity Index}

Based on these five sub-indicators, we computed the KII both at the ethnicity level and at country level. To create the ethnicity-level KII, we standardized each sub-indicator and then calculated the mean across the five sub-indicators for each ethnicity. We obtained the KII for 977 ethnicities. For ease of interpretation, we standardized the KII at the ethnicity level (this KII is used in Section S6.2 and Section S7 where we directly match ethnicities to the European Social Survey and World Value Survey). Table S1.1 displays the correlation matrix between the ethnicity-level KII and all five sub-indicators. Figure S1.6 gives an overview of the ethnicity-level KII.

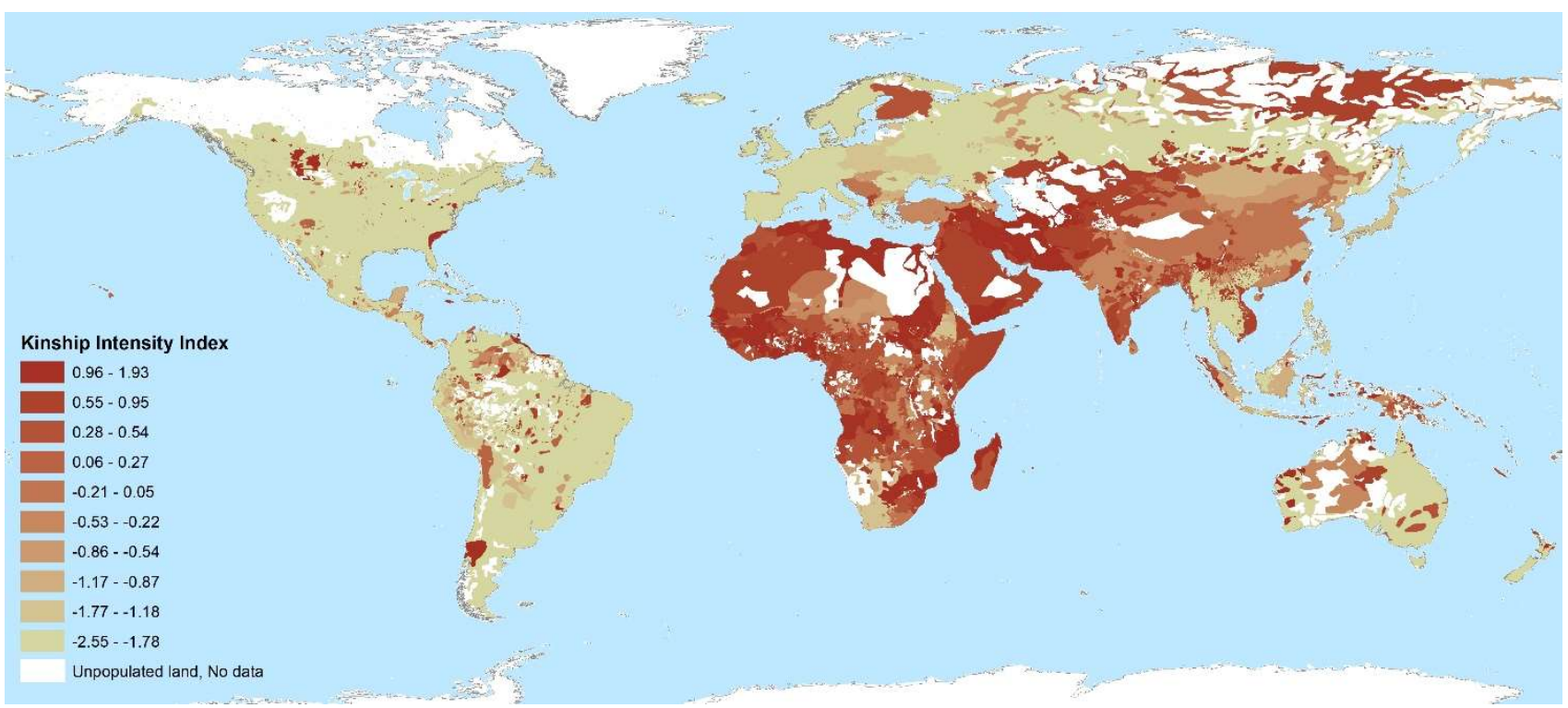


Figure S1.6 Kinship intensity index (KII) across ethnic/language groups. Higher KII corresponds to higher kinship intensity.

\begin{tabular}{|c|c|c|c|c|c|c|}
\hline & KII & $\begin{array}{c}\text { Cousin } \\
\text { Marriage pref. }\end{array}$ & Polygamy & $\begin{array}{c}\text { Co-residence } \\
\text { of extended fam. }\end{array}$ & $\begin{array}{c}\text { Lineage } \\
\text { organization }\end{array}$ & $\begin{array}{l}\text { Community } \\
\text { organization }\end{array}$ \\
\hline KII & 1 & & & & & \\
\hline Cousin marriage preference & 0.4683 & 1 & & & & \\
\hline Polygamy & 0.5670 & 0.0479 & 1 & & & \\
\hline Co-residence of extended families & 0.5670 & 0.0679 & 0.2398 & 1 & & \\
\hline Lineage organization & 0.7316 & 0.2151 & 0.2664 & 0.2095 & 1 & \\
\hline Community organization & 0.5902 & 0.0357 & 0.1060 & 0.1454 & 0.4418 & 1 \\
\hline
\end{tabular}

Table S1.1 Ethnicity-level Pearson correlation between the KII and its five sub-indicators.

Our country-level KII is the population-weighted average KII across todays ethno-linguistic populations within a country. Compared to the previous literature as pioneered by Giuliano and Nunn (44), we introduced two methodological innovations to aggregate the EA information to the country level. First, rather than manually matching ancestral EA ethnicities to present-day ethnicities within a country, we devised an algorithm that matches ethnicities. Matching is thus done parsimoniously following the pre-specified criteria based on linguistic distance (and in case of ties, based on geographic distance). Second, in cases in which information on one sub-indicator of an existing EA ethnicity was missing, we similarly applied the algorithm. Aggregating with population weights thus gives us country-level estimates (see Section S8 for details on the methodology). For ease of interpretation we standardized the country-level KII. Table S1.2 displays the correlation matrix between the country-level KII and all five country-level sub-indicators. Figure S1.7 give an overview of the country-level KII. 


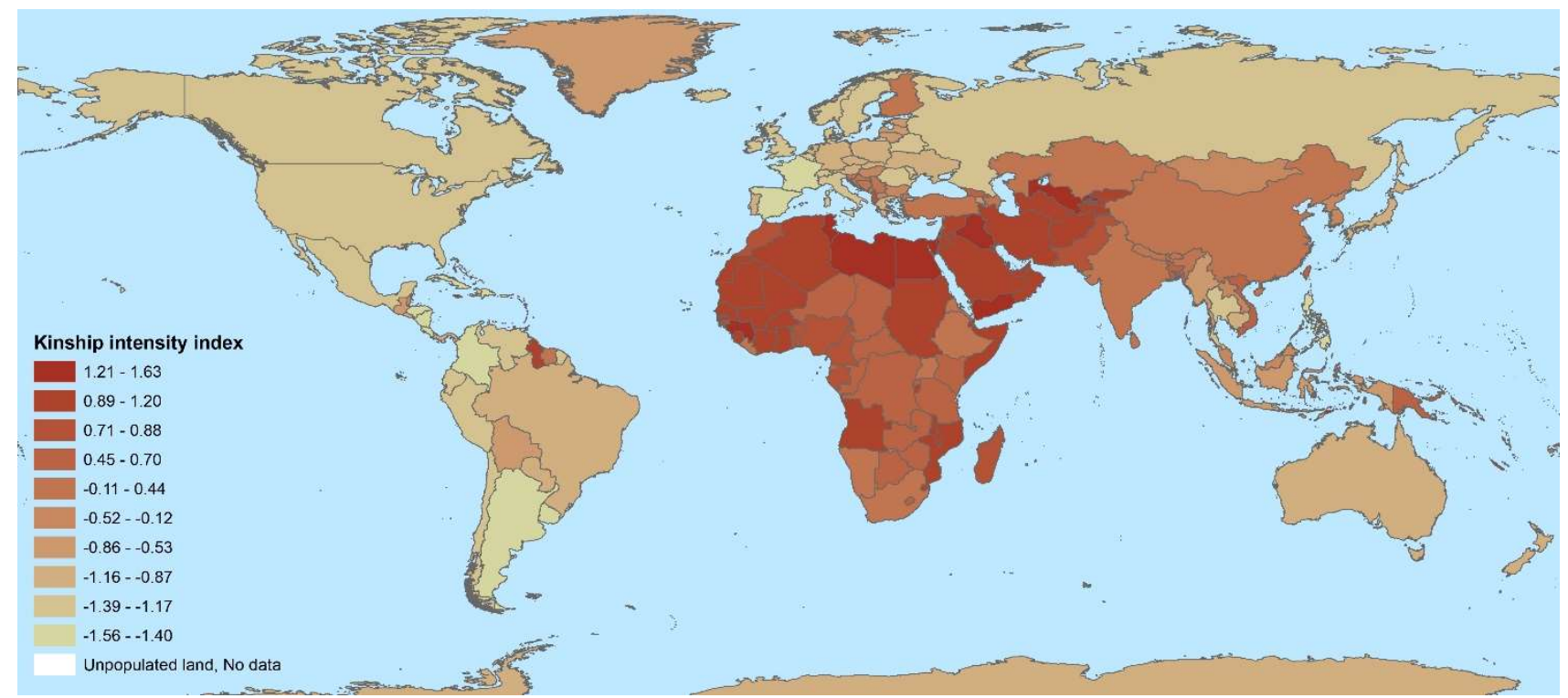

Figure S1.7 Kinship intensity index (KII) across countries. Higher KII corresponds to higher kinship intensity.

\begin{tabular}{|c|c|c|c|c|c|c|}
\hline & KII & $\begin{array}{c}\text { Cousin } \\
\text { marriage pref. }\end{array}$ & Polygamy & $\begin{array}{c}\text { Co-residence } \\
\text { of extended fam. }\end{array}$ & $\begin{array}{c}\text { Lineage } \\
\text { organization }\end{array}$ & $\begin{array}{l}\text { Community } \\
\text { organization }\end{array}$ \\
\hline KII & 1 & & & & & \\
\hline Cousin marriage preference & 0.6208 & 1 & & & & \\
\hline Polygamy & 0.8058 & 0.3365 & 1 & & & \\
\hline Co-residence of extended families & 0.8366 & 0.3623 & 0.5679 & 1 & & \\
\hline Lineage organization & 0.9254 & 0.4948 & 0.7286 & 0.7543 & 1 & \\
\hline Community organization & 0.6653 & 0.1723 & 0.4960 & 0.4674 & 0.5811 & 1 \\
\hline
\end{tabular}

Table S1.2 Country-level Pearson correlations between the KII and its five sub-indicators

\section{S1.2. Percent cousin marriage}

Our second indicator of kinship intensity is the percentage cousin marriages. We construct two variables that measure the percentage of cousin marriages: one at the country level and the other at the European-region level.

\section{Country-level percent of cousin marriage}

At the country level, this indicator contains cousin marriages up to and including second cousin marriages (that is, uncle/niece, aunt/nephew, first cousins, first \& second cousin, and second \& second cousin marriages). It is based on meta-analyses by Bittles (45-47), as reported on www.consang.net. 


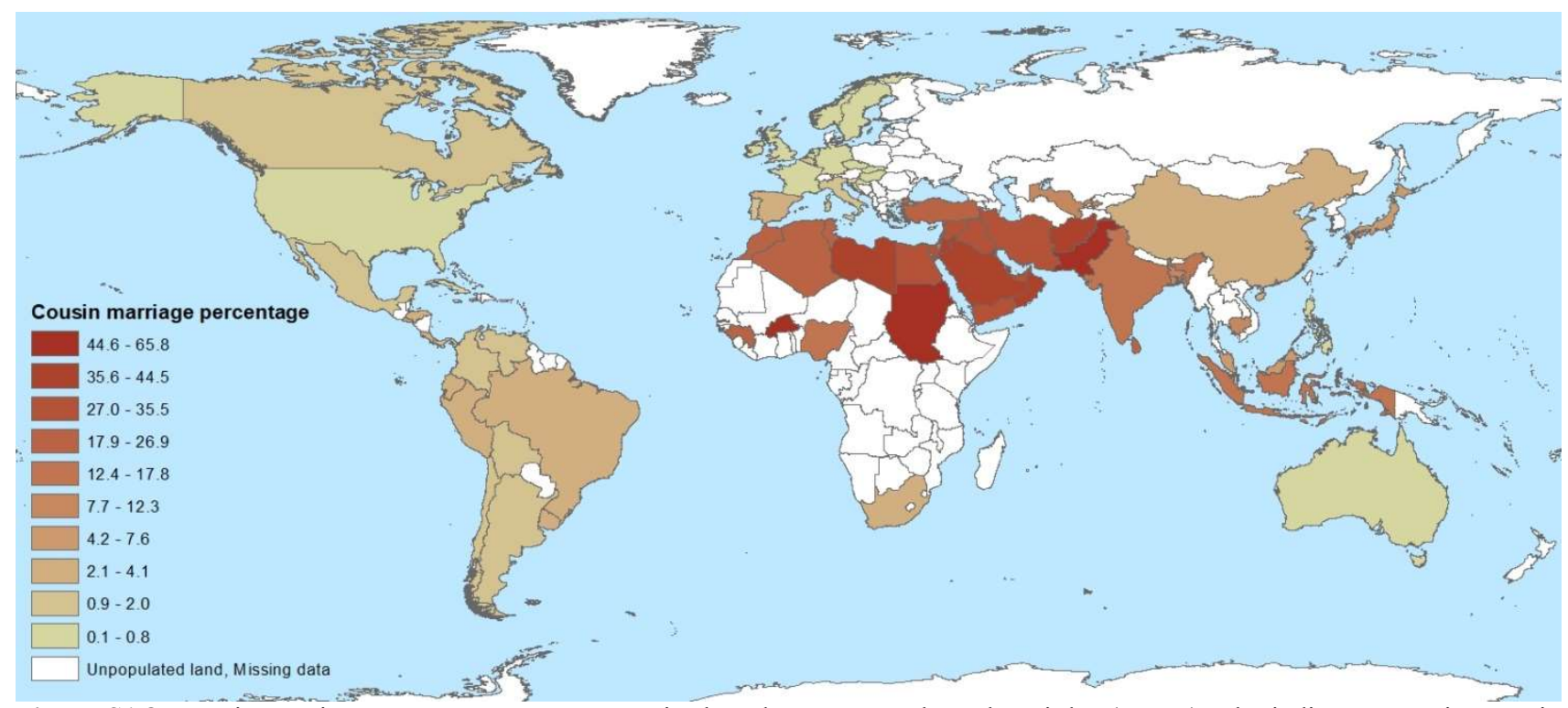

Figure S1.8. Cousin marriage percentage across countries based on meta-analyses by Bittles (45-47). The indicator contains cousin marriages up to and including second cousin marriages.

While the KII includes cousin marriage preference as one sub-indicator, the indicator Log percent of cousin marriage is distinct from this sub-indicator. The latter has the desirable property of containing information on the actual extent of cousin marriage in the $20^{\text {th }}$ century, rather than being an ordinal measure. A disadvantage the data shares with other data based on meta-studies is that the underlying studies vary in their methodology and sampling period. However, Log percent of cousin marriage is highly correlated with the country-level EA based sub-indicator cousin marriage preference, demonstrating the high consistency of the two measures over time (Spearman's $\rho=0.71, N=73, P<0.001$ ). Moreover, genetic correlates of inbreeding and Bittles' data have been shown to be moderately correlated (48). In cases where there were multiple studies covering one country, we took the average across the studies. In cases in which several studies covered different parts of a country, we took the population-weighted average. Based on other sources, we added three countries (Malta (49), Germany (50), and Uzbekistan based on the Demographic and Health survey (DHS)) giving us a total sample of 74 countries. The sample mean is $14.3 \%$, the standard deviation is $16.9 \%$, and the median is $4.25 \%$. We use the natural log of Percentage of cousin marriage in our analysis, both because of the distribution being left skewed and because the log reflects that cousin marriage probably has a decreasing marginal impact. It reflects that an increase from $1 \%$ to $2 \%$ probably has a bigger impact on psychological outcomes then going from $42 \%$ to $43 \%$. For example, the second kin-marriage between two already connected families doesn't double the tightness or closeness of their social relationship. Log transformation was straightforward as in no cases a country (or region) had no cousin marriages. Figure S1.8 reveals the world-wide variation in the percentage of cousin marriage at the country level.

\section{European-region-level log percent of cousin marriage}

A valuable source of information on $20^{\text {th }}$ century regional variation in intensive kin-networks in Europe are marital dispensations by the Catholic Church. Individuals who were granted a dispensation (usually involving a payment to the Church) were allowed to marry relatives within the forbidden degrees. After the year $1215 \mathrm{CE}$ (following the decrease of the ban to the $4^{\text {th }}$ degree), the granting of dispensations became more common in the Catholic Church $(51,52)$. The Church kept records on dispensations. Based on these 
dispensations, we obtained data on first cousin marriage for Spain (53), Italy (54), and France $(55,56)$ at the regional level. In addition, we added regional data on cousin marriage in Turkey based on the Demographic and Health survey (DHS). This allowed us to include a non-Christian European country where we likewise have psychological variables at the regional level based on the European Social Survey (ESS). Unlike the cross-country data from Bittles (which includes kin marriages up to and including second cousins), for the regional European data we only use kin-marriages up to and including first cousin marriages (which includes also uncle-niece marriages). We do not analyze data on second cousin marriages, as these are missing for Sicily. ${ }^{5}$ Years of observations are averages over the years 1911 to 1943 for Spain, 1910 to 1964 for Italy, and 1926 to 1958 for France; for Turkey data were collected in 1998 (in the second wave of the DHS survey in Turkey $\left.{ }^{6}\right)$.

\footnotetext{
${ }^{5}$ Due to higher cousin marriages rates in Sicily, bishoprics rather than the Vatican could grant dispensations for second cousin marriages. For this reason, they are missing in the Vatican archives).

${ }^{6}$ The earlier wave contains data on consanguinity, but no fine grained regional information.
} 


\section{S2. The Churches' Marriage and Family Program}

Many researchers have pointed out the existence of a distinct "European family", and several have linked it to the Church's marriage prohibitions we will call the Churches' Marriage and Family Program (MFP) (25, 51, 57-72). This section discusses the historical background of the MFP (Section S2.1) and the construction of our country-level (Section S2.2) and regional-level (Section S2.3) indicators of exposure to the medieval Churches. This allows to empirically investigate the role of the Church in forming the European family pattern. Since all dates in this section refer to the Common Era, we refrain from stating that explicitly.

\section{S2.1. Background}

Here, we provide an overview of the development of the Churches' Marriage and Family Program (MFP). First, we sketch the gradual extension and diverging development of the Catholic and Orthodox branches of Christianity. This is done based on historic sources on Church (and secular) legislation. We then describe the historical evidence regarding the enforcement of the MFP and discuss the reasons for the implementation of the MFP.

\section{Overview of the development of the Churches' MFP regulations}

Religions vary greatly in how their religious beliefs and practices shaped kin-based institutions (66-68, 73, 74). This is the case even within the Abrahamic religions. For example, Islam adopted inheritance customs that that promoted a nearly unique form of parallel cousin marriage in which a daughter marries her father's brother's son - implying patrilineal clan endogamy $(66,67)$. Even between different Christian sects differences exist. The extent of most Christian Churches' marriage regulations goes far beyond proscriptions in the Bible. In the Bible, incest is dealt with in Leviticus 18, Leviticus 20 and Deuteronomy. It prohibits marriage with one's mother, step-mother, mother-in-law, parent's sister, uncle's wife, sister, half-sister, sisterin-law (if the wife was still alive), stepdaughter, daughter-in-law, and wife's child's daughter. This contrasts particularly with the Western Church's prohibitions that at one point banned marriage up to sixth cousins, that is, with anyone sharing one of their 128 great-great-great-great-great grandparents. Affinal and spiritual kin were also included in the marriage prohibitions (51). This extension of marriage regulations in the Christian religion was a gradual one and far from uniform among different regions and strands that would later form into different Churches.

The first extensions occurred in Late Antiquity in the Roman Empire and focused on the sororate (marriage of a man with his wife's sister) and the levirate (marriage of man with his brother's wife). These initial regulations, dating from the Synods of Elvira (around 304/5) and Neocaesarea (314/5) and which are also endorsed in writings of Basil of Caesarea (330 to 379), are widely shared among different Christian Churches (51). Probably influenced by St. Augustine and St. Ambrose, in 387 the last Emperor of the joint Eastern and Western Empire, Theodosius, passed legislation prohibiting first cousin marriage. This law was soon revoked in 405 in the Eastern Empire and it is not clear how long it persisted and whether and to what degree it was enforced in the Western Empire (51). At the end of the $5^{\text {th }}$ century, the Christian Western Roman Empire collapsed, and in its place Germanic kingdoms emerged. The Church's MFP could have thus been only a short episode in Western Europe. However, while different Churches followed different legislation, it was in 
the Germanic successor kingdoms of the Western Roman Empire that the Church implemented the most extended MFP with the most stringent enforcement.

Before the introduction of the Church's MFP the Germanic and Slavic populations exhibited the characteristics of societies with high kinship intensity. Evidence for the importance of genetic relatedness for social organization, and the presence of lineages comes from diverse sources: paleogenomics (75), historic written sources like Tacitus' Germania or Caesar's De bello Gallico, early Germanic law codes, which are designed for a society based on descent and kinship, biographies of saints, Nordic and German sagas, and kinship terminologies consistent with intensive kinship. Moreover, the very fact that ample historical documents including many letters exchanged by popes, bishops and kings attest that the Church prohibited, criticized and persecuted the practice of sororate, levirate and cousin marriages, demonstrates the existence of those marriage practices $(25,51,63,76-85)$. These practices were not restricted to Germanic and Slavic tribes. They were also found among Romans and other population around the Mediterranean Sea (51).

In the following we describe the developments in the Eastern and Western Churches' MFP with regard to incest legislation. Additional features of the Churches' MFP are its prohibitions of polygamous marriages, the indissolubility of marriage and its stance against adoption - all factors that weaken kinship intensity. For example, blocking adoption might lead lineages without sufficient genetic offspring to die out. As a consequence of this policy, legal adoption makes no appearance in English law until 1926, where it followed the legalization of adoption in France (1892) and Massachusetts (1851) (25). The Church's early stance against polygamy, despite its presence among the Patriarchs in Old Testament, can be found in the writings of Basil of Caesarea (329 or 330 to 379) and Augustine of Hippo (354-430) (78).

We use the term "Western Church" rather than Roman Catholic or Papal Church and "Eastern Church" rather than Orthodox Church to denote that in Late Antiquity, the Churches were only just forming. While the Schism between the Roman Catholic and the Eastern Orthodox Churches is associated with the year $1054 \mathrm{CE}$, this only marked the endpoint of a long divergence. ${ }^{7}$ Within the realm of the Church in the West (what was to become the Roman Catholic Church), distinct incest legislation and enforcement developed from the beginning of the $6^{\text {th }}$ century onward. Here, we focus only on the Western and Eastern Churches as they would emerge as dominate. Others Christian sects with different marriage prohibitions existed. For example, Celtic and Nestorian Christianity enforced no prohibitions that went beyond those stated in the Bible (51). This is

\footnotetext{
${ }^{7}$ With the split of the Roman Empire into a Western and Eastern (Byzantine) empire, a cultural divergence set in with two emerging ecclesial centers (Rome and Constantinople). Theological divergence becomes apparent surrounding the decisions of the Synod of Trullo in 692 and in the iconoclast controversy, when the Byzantine Emperor, who claimed superiority over the Church, forbade icon veneration (726-729). This was resisted in the West and the Emperor retaliated by putting the South of Italy and probably Eastern Illyricum under the authority of the Patriarch in Constantinople. The divide deepened when the Pope in Rome turned to Carolingian rulers for assistance against the invading Lombards in mid- $8^{\text {th }}$ century. This weakened Byzantine influenced over the Western Church and freed it more generally from subordination to secular rulers allowing it to become relatively independent. In the East the emperors saw himself above the Patriarch and subordination to the Emperor is evident. At the time of the Schism in 1054, the mutual excommunication was not considered significant by contemporary historians or the laity (239).
} 
important because it underlines the point that this isn't about Christianity per se, but about specific Christian sects. $^{8}$

\section{The Western Church's MFP}

Even within the realm of the Western Church, the development of the MFP was not a uniform one. Initially, the Western Church's MFP was closely tied to the area that was to become the Carolingian Empire. Historians have talked about an obsession with incestuous marriages in the Merovingian kingdom from the $6^{\text {th }}$ into the beginning of the $7^{\text {th }}$ century $(51,86)$. Out of 17 Synods between 511 and 627,13 dealt with incestuous marriages. The first Synod to ban cousin marriage was the Synod of Agde in the Visigothic Kingdom in 506..$^{9}$ Another important Synod was the Synod of Epaone (517) in the Burgundian Kingdom, which banned marriage up to and including second cousins. Subsequent Merovingian Synods largely followed and inculcated these regulations. Probably influenced by these developments in Gaul, Synods with similar regulations also occurred in Visigothic Spain. At the end of the $6^{\text {th }}$ century, rulers in Merovingian France and Visigothic Spain implemented secular incest prohibitions. At around the same time, missionary activity by St-Augustine of Canterbury began implementing a ban on sororate, levirate and first cousin marriage in England (51).

About a century after the last Merovingian Synod (627), which dealt with incestuous marriage, new decrees and initiative came directly from the popes. Pope Gregory II and then Pope Zacharias banned marriage with all kinsmen (without specifying the extent) ${ }^{10}$. In 741 Pope Zacharias extended the ban to marriages between godfathers and their god-children or their god-children's mothers. At around the same time, a strong push against incest occurred under the Carolingian King Pepin (714-768) and subsequently by his son, Emperor Charlemagne (742-814). Both rulers, working in close alliance with the Popes, put incest legislation at the forefront of their political agenda. In Pepin's only preserved capitulary for the whole Frankish Empire, the first three of the seven capitulum focus on, or at least mention, incestuous marriages. These prohibited the marriage of a man with his god-child's mother or godmother; his deceased wife's mother, daughter, or sister; and his blood relatives up to second cousins. ${ }^{11}$ Proscribed punishment for violation included confiscation of property; offenders who did not own property were typically put in jail, or if they had the status of "unfree" they were beaten. Furthermore, Pepin convened three Synods that centered on questions of incestuous unions. Apart from banning incestuous marriages, one of those three Synods, the synod of Ver in 755, made it

\footnotetext{
${ }^{8}$ The Armenian, Melchite, and Coptic Churches followed the writing of Basilius (about 330 to 379) banning sororate marriages. Cousin marriage in the Coptic Church was never forbidden, the Armenian Church adopted the Eastern Church prohibitions in Late Antiquity, while the Syriac-Orthodox Church only extended the marriage prohibition during the High Middle Ages. The Ecolga (741) of Leo III, which banned up to and including second cousin marriages, was disseminated in Slavic, Armenian and Arabic language (51).

${ }^{9}$ The prohibition of cousin marriage is likely in the tradition of St. Augustine and Ambrose, who both resided in Milan. Also note, that while the synod of Agde was the first one in Gaul, compared to the Synod of Epaone in 517 the impact was likely rather limited since the Synod of Agde was held in the Visigoth kingdom, which followed Arianism (51).

${ }^{10}$ Pope Gregory III (731-741) specified the extent by referring to the $7^{\text {th }}$ degree of relatedness according to Roman counting (51). This counting method counts up to and then down from the common ancestor. The $7^{\text {th }}$ degree thus implies that marriages between a man and his second cousin once removed (that is, counting three up and four down) are considered incestuous, while third cousins are allowed to marry (since they are related in the $8^{\text {th }}$ degree Roman counting).

${ }^{11}$ Under Pepin, the marriage prohibitions were later extended to third-degree cousins.
} 
mandatory for marriages to be public, thus aiding enforcement. Charlemagne continued his father's policies ${ }^{12}$ putting yet more emphasis on policies that would aid enforcement, as we further discuss below (51).

The historian Karl Ubl (51) discusses a radicalization of the Western Church's MFP in the $11^{\text {th }}$ century. In 1003, Holy Roman Emperor Henrich II extended the prohibition on cousin marriage to include up to sixth cousins, thus forbidding marriage between a man and a woman who had one of their 128 great-great-greatgreat-great-grand-parents in common. While the MFP could not be enforced to this degree (as ancestors could not be traced that far), it did imply a further restriction in the set of possible marriage partners for the nobility, who could typically trace ancestors up to around fourth cousins. An important Church document is Bishop Burchard of Worms' Decretum, which started to circulate around 1023. This canon law collection was widely distributed and included the ban up to and including sixth cousins. In 1059, a Synod under Pope Nikolas II increased the ban to sixth cousins in the whole realm of the Western Church. ${ }^{13}$ At this point, the Western Church was a centralized power and the momentum on marriage legislation rested largely with the Pope.

In 1215 at the Fourth Lateran Council, the ban was reduced to third cousins and dispensations became more common. Two factors contributed to this decrease. First, it was getting increasingly hard for nobles to find a noble marriage partner, who was permissible under the incest legislation. Second, the incest legislation was increasingly used to annul existing marriages. Henry the VIII is the most prominent example. He wanted to annul his marriage with Anne Boleyn on the grounds that this marriage was of a forbidden degree.

\section{The Eastern Church's MFP}

In addition to the bans on the sororate and levirate, in 530 the Byzantine Emperor, Justinian, prohibited the marriage between godfather and godchild (51). The next tightening of the MFP occurred at the Council of Trullo (692 CE). It forbade (i) cousin marriage, (ii) a father and a son from marrying a mother and a daughter, or two sisters, (iii) two brothers from marrying a mother and a daughter or two sisters, and (iv) a godfather from marrying his god-child's mother. In 741, under the Isaurian ruler Leo III, the ban was increased to include second cousins. ${ }^{14}$ In the Orthodox Church, third cousins were always allowed to marry (87). Unlike for the Western Church, there is no evidence the Eastern Church had an "obsession" with incestuous marriages. Evidence that enforcement was lax comes in 1166. At a Synod in Constantinople, the ban was reenforced. The practice that spouses could claim "ignorance" (that is, marriages were not dissolved when spouses claimed that they did not know about their consanguineous relation) was abrogated at the Synod.

Table S2.1 gives and overview of the incest legislation of the Eastern and Western Church. Following Synodal and subsequent historic writings, the prohibitions are stated from the male perspective.

\footnotetext{
${ }^{12}$ In 22 of his capitularies, 25 regulations regarding incestuous marriages are found (51).

${ }^{13}$ There was some debate on how to determine degrees of relatedness for this extended ban. Namely whether to include or exclude the common ancestor. Depending on this it could also have implied a ban of only up to and including $5^{\text {th }}$ cousins. For practical purpose this does not make a big difference. Here we talk about the $6^{\text {th }}$ degree as interpreted in the Decretum of Burchard of Worms.

${ }^{14}$ The Byzantine Emperors claimed and exerted superiority over the Church. A separation into secular vs. ecclesial legislation is therefore hardly possible.
} 


\begin{tabular}{|c|c|}
\hline Year CE & Church's Prohibition \\
\hline $305 / 6$ & $\begin{array}{l}\text { Synod of Elvira (Spain) decrees that any man who takes the sister of his dead wife as his new wife (sororate } \\
\text { marriage) should abstain from communion for five years. Those marrying their step-daughter should abstain } \\
\text { from communion until near death. }\end{array}$ \\
\hline $314 / 5$ & $\begin{array}{l}\text { Synod of Neocaesarea (Turkey) forbids marrying the wife of one's brother (levirate marriage) and possibly } \\
\text { sororate marriage. }\end{array}$ \\
\hline 325 & The Synod of Nicaea (Turkey) prohibits sororate marriage. \\
\hline 355 & Levirate marriage is prohibited by Emperor Constantius II. \\
\hline 374 & Basilius of Caesarea argues against sororate marriage in a letter to Diodor von Tarsus. \\
\hline 387 & $\begin{array}{l}\text { The Christian Roman Emperor Theodosius reaffirms prohibitions against sororate and levirate marriages. In } \\
\text { addition, he prohibits first cousin marriage. This law was reversed in } 400 \text { or } 404 \text { in the Eastern Empire, while in } \\
409 \text { Western Emperor Honorius softened it by allowing dispensation. It is not clear whether and how long it } \\
\text { persisted in the West. The dissolving Western Empire (Rome was plundered in } 410 \text { ) makes continued } \\
\text { enforcement unlikely. }\end{array}$ \\
\hline around 400 & $\begin{array}{l}\text { In letters to the Gallic bishops, the Pope argues that the sororate marriage is forbidden for Christians and calls } \\
\text { for penalties and the annulment of such marriages. }\end{array}$ \\
\hline 402 & Roman Synod (Italy) under Pope Innocent I forbids sororate marriage. \\
\hline 506 & $\begin{array}{l}\text { Synod of Agde (France) prohibits marriage to one's brother's widow, wife's sister, stepmother, uncle's widow, } \\
\text { uncle's daughter, stepdaughter, cousin or any kinswomen. }\end{array}$ \\
\hline 517 & $\begin{array}{l}\text { Synod of Epaone (France) decrees that unions up to and including second cousins are incestuous, and } \\
\text { henceforth forbidden (although existing unions were not dissolved). It also forbids marriage to stepmothers, } \\
\text { widows of brothers, sisters-in-laws, and aunts by marriage. Many subsequent Synods in the area of what would } \\
\text { become the Carolingian Empire refer to this Synod for incest regulations. }\end{array}$ \\
\hline 530 & $\begin{array}{l}\text { Prohibition of marriage between godfather and godchild (and restriction of marriage between a man and his } \\
\text { adopted child) by Byzantine Emperor Justinian. }\end{array}$ \\
\hline $527 / 31$ & $\begin{array}{l}\text { Second Synod of Toledo (Spain) prescribes excommunication for marrying blood relatives (the number of years } \\
\text { of excommunication should equal the number of years of the marriage). }\end{array}$ \\
\hline 533 & The Synod of Auvergne (France) repeats the legislation of the Synod of Epaone and Agde. \\
\hline 535 & $\begin{array}{l}\text { Byzantine Emperor Justinian increases punishment for levirate and sororate marriage to confiscation of } \\
\text { property, a prohibition on holding administrative positions, exile and, for lower status people, whipping. }\end{array}$ \\
\hline 538 & $\begin{array}{l}\text { The third Synod of Orleans (France) prohibits marriage to one's stepmother, stepdaughter, brother's widow, } \\
\text { wife's sister, cousin and uncle's widow. }\end{array}$ \\
\hline 538 & $\begin{array}{l}\text { First documented letter between a Frankish king and the Pope is about incest (marriage to the wife of one's } \\
\text { deceased brother). While the Pope disapproves, he leaves the decision about the extent of the penance to } \\
\text { bishops. }\end{array}$ \\
\hline 541 & The Fourth Synod of Orleans (France) renews the canon of the Third Synod of Orleans. \\
\hline 546 & Synod of Lerida (Spain). Re-enforces proscriptions of the Synod of Toledo but decreases punishments. \\
\hline 557 & $\begin{array}{l}\text { The third Synod of Paris (France) prohibits marriage to one's brother's widow, stepmother, uncle's widow, } \\
\text { wife's sister, daughter-in-law, aunt, stepdaughter, and step-daughter's daughter. }\end{array}$ \\
\hline 567 & $\begin{array}{l}\text { Second Synod of Tours (France) forbids marriage to one's niece, cousin, or wife's sister and confirms the } \\
\text { canons of Orleans, Epaone, and Auvergne. }\end{array}$ \\
\hline 578 & $\begin{array}{l}\text { The Synod of Auxerre (France) forbids marriage with stepmother, stepdaughter, brother's widow, wife's sister, } \\
\text { cousin, uncle's widow. }\end{array}$ \\
\hline 583 & The third Synod of Lyons (France) renews canons against incest. \\
\hline 585 & Second Synod of Macon (France) renews canons against incest. \\
\hline 589 & $\begin{array}{l}\text { Reccared, the Visigothic King (Spain), decrees the dissolution of incestuous marriages, punishing offenders } \\
\text { with exile and the transfer of their property to their children. }\end{array}$ \\
\hline 596 & $\begin{array}{l}\text { Frankish King Childbert II decrees death penalty for marriage to one's step-mother. Other forms of violations } \\
\text { shall be penalized according to bishops. If the convicted shows resistance to ecclesial punishment, his property } \\
\text { is seized and redistributed to relatives. }\end{array}$ \\
\hline 600 & $\begin{array}{l}\text { In a letter to his missionary Augustine of Canterbury in England, Pope Gregory I prohibits marriage to first } \\
\text { cousins, as well as sororate and levirate marriages. This letter (libellus responsium) is widely distributed. }\end{array}$ \\
\hline 615 & $\begin{array}{l}\text { The Fifth Synod of Paris (France) renews the legislation of the Synods of Orleans, Epaone, Auvergne, and } \\
\text { Auxerre. }\end{array}$ \\
\hline 627 & $\begin{array}{l}\text { Synod of Clichy implements the same punishment and enforcement procedures that were decreed by the } \\
\text { Frankish King Childbert II in } 596 .\end{array}$ \\
\hline 643 & Lombard laws of Rothari forbid marriage to one's stepmother, step-daughter, or sister-in-law. \\
\hline 673 & $\begin{array}{l}\text { Synod of Hertford (England) forbids incest (without specifying the extent) and decrees that one man can only } \\
\text { marry one woman and no man shall leave his wife except because of infidelity. If he does leave her, he cannot } \\
\text { remarry. }\end{array}$ \\
\hline 690 & Bishop Theodore of Canterbury's (England) widely distributed penitentials forbid first cousin marriages but do \\
\hline
\end{tabular}


not demand that these marriages must be dissolved. Affinal relatedness are likewise included in the prohibitions. At the Synod of Trullo (Turkey), the Eastern Church forbids marriage to one's first cousin and also affinal kin: a father and a son marrying a mother and a daughter or two sisters, and two brothers marrying a mother and a daughter or two sisters. It also forbids marriage of a godfather to his godchild's mother.

716 In a legation to Bavaria, Pope Gregory II prohibits marriage up to first cousins. The penalty is excommunication.

Roman Synod (Italy) under Pope Gregory II prohibits marriage to one's brother's wife, niece or grandchild, stepmother and stepdaughter, cousins, all kinsmen, and anyone married to kinsmen. It also prohibits marriage to

721 one's godmother. In the year 726, Gregory II specifies that for practical missionary purposes the prohibitions are up to first cousins, but for others the prohibitions include all known relatives. His successor Gregory III specifies this prohibition such that marriages of third cousins are allowed. Prohibitions include affinal kin. The decisions of the council are widely disseminated.

723/4 Lombard king Liutprand (Italy) prohibits marriage with one's step mother, step daughter, sister-in-law and widows of cousins.

$725 \quad$ Roman Synod (Italy) threatens anathema against those who marry their godmothers.

741 Pope Zacharias forbids the marriage of a godfather with his godchild or the godchild's mother.

Under the Byzantine Emperor Leo III (the Isaurian), the prohibition in the Eastern Church is increased to

741 include marriage of second cousins (and not much later to marriage between second cousins once removed). The penalty for of cousin marriage is whipping.

743 Roman Synod (Italy) under Pope Zacharias orders all to refrain from marrying cousins, nieces and other kin. Such incest was punishable by anathema and excommunication.

The Synod of Metz (France) prohibits marriage to one's step-mother, stepdaughter, wife's sister, niece, granddaughter, cousin, and aunt, decreeing that any offender will be fined. If unable to pay the fine, the offender

753 will be sent to prison if he is a freeman, and if not, will to be beaten with many stripes. It also prohibits the marriage of a father with the godmother of his child, and the marriage of a child with his godmother, and the marriage of a confirmed person with the person who presented him or her for confirmation.

755 The Synod of Verneuil (France), convened under Carolingian King Pepin, commands marriages to be performed publicly.

756 Synod of Verbiere (France) prohibits marriage of third cousins and closer. It pronounces that those married to

756 second cousins are to be separated, while those married to third cousins are only to do penance.

756/7 Synod of Aschheim (Germany) forbids incestuous marriages.

757 Synod of Compiegne (France) rules that existing marriages of a man with a second cousin once removed (the

757 child of a second cousin) or closer should be nullified. This is also the case for affinal kin. The Frankish King, Pepin, threatens secular punishment for any who disagree with the decisions of the Synod.

786 Papal legates in England forbid incestuous marriages with relatives and kin (without specifying the extent). Synod of Friuli (Italy) directs attention to pre-nuptial investigations into potentially consanguineous marriages

796 and prohibits clandestine unions. It prescribes a certain waiting time before marriage to find out from neighbours and elders whether there exist any blood relations that would prohibit marriage.

\begin{tabular}{|c|c|}
\hline 802 & $\begin{array}{l}\text { Charlemagne's capitulary of } 802 \text { insists that nobody should attempt to marry until the bishops and priests, } \\
\text { together with the elders of the people, have investigated the blood relations of the prospective spouses. (Saxon } \\
\text { capitularies enacted in } 785 \text { in Paderborn included fines for contracting unlawful marriages). }\end{array}$ \\
\hline 813 & Synod of Arles (France) reaffirms the prohibitions of previous Synods. \\
\hline 813 & $\begin{array}{l}\text { Synod of Mainz (Germany) forbids marriage between third cousins or closer as well as marriage with one's } \\
\text { godchild or godchild's mother, or the mother of the child that one offered for confirmation. The latter } \\
\text { restrictions are also confirmed by Pope Nicholas I in } 860 \text { in his reply to the Bulgarians. }\end{array}$ \\
\hline 874 & $\begin{array}{l}\text { Synod of Douci (France) urges restraint from marriage to third cousins. To strengthen the ruling, the Synod } \\
\text { made the children of such incestuous marriages ineligible for succession to an estate. }\end{array}$ \\
\hline 909 & $\begin{array}{l}\text { Synod of Trosle (France) clarifies and affirms the Synod of Douci, deeming that children born in an incestuous } \\
\text { marriage are ineligible to inherit property or titles. }\end{array}$ \\
\hline 922 & Synod of Koblenz (Germany) reaffirms the provisions of the Synod of Mainz in 813. \\
\hline 927 & Synod of Trier (Germany) decrees penance of 9 years for marriage between in-laws and blood relatives. \\
\hline 948 & Synod of Ingelheim (Germany) prohibits marriage with all kin as far back as memory goes. \\
\hline 997 & $\begin{array}{l}\text { Tomos of Sisinnios (Patriarch of Constantinople) forbids affinal marriages (of two brothers with two (female) } \\
\text { cousins, two (male) cousins with two sisters, an uncle and his nephew with two sisters, or two brothers with an } \\
\text { aunt and her niece). }\end{array}$ \\
\hline 1003 & $\begin{array}{l}\text { Synod of Diedenhofen (Germany). Emperor Heinrich II increases the ban to include sixth cousins, forbidding } \\
\text { marriage between people who share one of their } 128 \text { great-great-great-great-great-grand-parents. }\end{array}$ \\
\hline 1023 & $\begin{array}{l}\text { Synod of Seligenstadt (Germany) forbids cousin marriage likewise to sixth cousins. Bishop Burchard of } \\
\text { Worms' Decretum, which extends incestuous marriages to sixth cousins, is popular and spreads. }\end{array}$ \\
\hline 1032 & Synod of Bourges (France) forbids cousin marriage (either up to second or sixth cousins) \\
\hline 1046 & Peter Damian, an influential Benedictine monk and cardinal, argues in favour of a ban up to and including sixth \\
\hline
\end{tabular}




\begin{tabular}{|c|c|}
\hline & cousins. \\
\hline 1047 & Synod of Tulujas (France) forbids cousin marriage \\
\hline 1049 & Synod of Rheims (France) forbids cousin marriage \\
\hline 1059 & $\begin{array}{l}\text { Synod of Rome (Italy). Pope Nicholas II forbids marriage to sixth cousins or as far back as relatives can be } \\
\text { traced. His successor, Pope Alexander II, likewise decrees that marriage to sixth cousins are forbidden. The } \\
\text { kingdom of Dalmatia gets a temporary dispensation, forbidding marriages only to fourth cousins. }\end{array}$ \\
\hline 1060 & Synod of Tours (France) reiterates the provisions of the 1059 Synod of Rome \\
\hline 1063 & $\begin{array}{l}\text { Synod of Rome (Italy) forbids marriage up to sixth cousins or closer. Laymen who have a concubine are } \\
\text { suspended from communion. }\end{array}$ \\
\hline 1072 & $\begin{array}{l}\text { Synod of Rouen (France) forbids 'occult' (non-Christian) marriages and decrees that the priest must inquire } \\
\text { about the relationship of those about to get married. }\end{array}$ \\
\hline 1075 & Synod of London (England) forbids marriages of sixth cousins or closer, including affinal kin. \\
\hline 1094 & Decretum of Ivo of Chartres: marriages of up to sixth cousins are forbidden \\
\hline 1102 & $\begin{array}{l}\text { Synod of London (England) nullifies existing marriages between sixth cousins. Third parties who knew that the } \\
\text { marriage was among relatives are were also implicated in the crime of incest. }\end{array}$ \\
\hline 1123 & $\begin{array}{l}\text { The First Lateran Council (Italy) condemns unions between blood relatives (without specifying the degree). It } \\
\text { declares that anyone who contracted an incestuous marriage will be deprived of hereditary rights. }\end{array}$ \\
\hline 1125 & Synod of London (England) repeats the provisions of the 1075 Synod of London. \\
\hline 1139 & The Second Lateran Council (Italy) condemns unions between blood relatives (without specifying the degree). \\
\hline 1140 & Decretum of Gratian: marriages of up to sixth cousins are forbidden \\
\hline 1142 & In Peter Lombard's Books of Sentences marriage is forbidden up to and including sixth cousins \\
\hline 1166 & $\begin{array}{l}\text { Synod in Constantinople (Turkey) re-enforces the earlier Eastern Church's prohibition on cousin marriages and } \\
\text { enforcement becomes stricter. }\end{array}$ \\
\hline 1174 & Synod of London (England) forbids clandestine marriages. \\
\hline 1176 & $\begin{array}{l}\text { Odo, Bishop of Paris (France), is associated with the introduction of "the banns of marriage". That is, the public } \\
\text { notice of impending marriages in front of the congregation. }\end{array}$ \\
\hline 1200 & $\begin{array}{l}\text { Synod of London (England) requires the publication of "the banns of marriage" and public marriages. Kin- } \\
\text { marriages are forbidden without specifying the extent. }\end{array}$ \\
\hline 1215 & $\begin{array}{l}\text { Fourth Lateran Synod (Italy) decreases the marriage prohibitions to third cousins, and all closer blood relatives } \\
\text { and in-laws. They also formalize and integrate prior rulings into a constitution of Canons. This brought pre- } \\
\text { nuptial investigation and marriage bans into legislation. }\end{array}$ \\
\hline 1917 & $\begin{array}{l}\text { Pope Benedict XV further decreases the marriage prohibitions to second cousins (and all closer blood relatives } \\
\text { and in-laws). }\end{array}$ \\
\hline 1983 & The Pope further decreases marriage prohibitions to include relatives only up to first cousins \\
\hline
\end{tabular}

\section{Enforcement}

An important question is whether the Church had the means to enforce its legislation. In the early medieval era, the Church was in its infancy. The Orthodox Church, and particularly the Catholic Church, would only later become powerful and centralized organizations. One important feature of the successful implementation and enforcement of the Western Church's MFP was the role of bishoprics. In the area of what was to become the Carolingian Empire, bishoprics fulfilled more than an ecclesial role: the Merovingian kings considered them as part of their administration, which gave bishops secular power as well.

Several historical accounts demonstrate the bishops' dedication in enforcing the MFP from early on. For example, shortly after the Synod of Epaon (517), the Burgundian king's treasurer was excommunicated because he married his deceased wife's sister. The king threatened the bishops with violence if they did not accept the marriage. In response, the bishops formed an alliance, suspended the king from the communion, 
and vowed to resign into monasteries if the king refused to stop his threats. If the bishops resigned into monasteries, important liturgical functions could not be performed in the bishops' respective cities. While the bishops were ultimately not successful in dissolving the treasurer's marriage, it is clear that they did not shy away from conflict with the king. Around 523, Merovingian king Chlothar I married the wife of his deceased brother against the proscriptions of the Church's MFP. Yet, when he wanted to marry the widow of his grandnephew around 555, the bishops successfully intervened $(51)$. In the $10^{\text {th }}$ and $11^{\text {th }}$ centuries, hardly any marriages that were not in line with the Church's MFP were recorded, and increasingly geographically distant marriages reveal the struggle of the nobility to find noble marriage partners (51). Marriages within the forbidden degrees were perceived as scandalous and weakened the social position of the people involved. For example, the marriage of William (who would later become known as William the Conqueror, King of England) was considered incestuous, and to appease the Church, he donated monasteries to the Church. King Robert II of France's marriage to his second cousin provoked a scandal and the Pope called to annul the marriage in 998 (some years later, it was dissolved and Robert II married a non-noble - exogamy had won over endogamy $(51))$.

These cases demonstrate that from early on, the Church had the willingness and power to restrict even marriages involving the nobility and kings, the most powerful secular leaders. Apart from constituting a strong signal to normal peasants, this suggests that the Church was certainly powerful enough to dissolve forbidden marriages of non-nobles. But did the Church have the capacity and information necessary to do so?

One important feature that aided in enforcement is that the MFP was seen and propagated as part of God's divine law. Even though not drawing directly from the Bible, Popes and bishops propagated the belief that incestuous marriage was against God's will. Thus, in addition to worldly punishment, such as excommunication by the Church, the death penalty, or confiscation of property, people faced the threat of God's revenge both on Earth and in the afterlife. Ubl (51) argues that the plague in the second half of the $6^{\text {th }}$ century was seen as God's punishment for incest. A letter signed by multiple bishops at the end of the $6^{\text {th }}$ century gives evidence of that. It urges people to appease God's anger through chastity and the dissolution of incestuous marriages. Similarly, Arabic victories in the $7^{\text {th }}$ century were interpreted as God's revenge for Byzantine Emperor Herakleios' incestuous marriage with his niece (51). These are examples in which the Church and the population attributed disasters to God's worldly punishment. In addition, punishment in the afterlife was an important threat for religious individuals. "Pollution of blood" through incestuous marriage and God's revenge is a reoccurring theme in the medieval era. For example, Charlemagne expressed concerns about the pureness of the Christian community and decreed that transgressors should be separated so that they could not pollute others $(51) .{ }^{15}$ In medieval literary sources, divine punishment, or at least violent death in some form, is the usual fate of the perpetrator in incest stories $(91) .{ }^{16}$

A third feature that helped the spread of the MFP is that secular rulers and bishops became aligned in their fight against incestuous marriages. Legislation against incestuous marriages are found in versions of the Lex Salica (second half of $6^{\text {th }}$ century in Merovingian France), Lex Romana Visigothorum (end of the $6^{\text {th }}$ century

\footnotetext{
${ }^{15}$ Fear of God's revenge is also mentioned by Holy Roman Emperor Henrich II when arguing against the incestuous marriage of his adversaries (51).

${ }^{16}$ As an example, see the novella "Apollonius of Tyre" which remained popular throughout the Middle Ages.
} 
in Visigoth Spain), and the Lombard Laws of Rothari ( $7^{\text {th }}$ century) and Liutprand ( $8^{\text {th }}$ century) ${ }^{17}$ In the case of incestuous marriage, the Lex Salica ordered annulment and the exclusion of children from inheritance. The Merovingian King Childebert II decreed the death penalty for marriage with one's step-mother. For other incestuous marriages, he put punishment in the hands of bishops. ${ }^{18}$ However, when the verdicts of bishops were ignored, he banned the person from his court and transferred their lost property to their relatives. Confiscation and redistribution of property to relatives increased financial incentives to report transgressions by those who were most likely to know about it - the relatives. Another reason for couples to contract a legitimate marriage was that this legitimized offspring, who then could inherit.

A secular push towards enforcement occurred under the Carolingian rulers Pepin (714-768) and Charlemagne (747/8-814). Both were closely aligned with the Popes. They decreed that marriages had to be public (allowing easier enforcement of the MFP by priests and peasants). Another policy was the push towards the creation of the parish system, which, once firmly embedded in the Church's hierarchical structure, allowed for greater control over peasants (other Churches, like the one in the Southern Italian Lombard kingdoms, or the Celtic Church in Ireland, Wales, and Scotland, lacked such a hierarchical structure). Charlemagne decreed that nobody should attempt to marry until the bishops and priests, together with the elders of the people, had inquired about the blood relations of the prospective spouses. In addition, he ordered that prospective spouses had to go through a pre-marriage interrogation. Charlemagne instigated inquisition about existing incestuous marriages and put the enforcement in the hands of the bishops. Before this policy change, bishops and courts typically only became active if there was an accuser. Now they had a mandate to actively inquire about and punish incestuous marriages. Lastly, he ordered the faithful to take an oath denouncing incestuous marriages (51). ${ }^{19}$ Evidence that bishops and peasants took the campaign against incest seriously and that denunciation occurred also among the peasantry is attested by letters between bishops (92). In the $11^{\text {th }}$ century, the Western or Papal Church was formed into a powerful organization that was able to enforce its MFP onto the inhabitants within their sphere.

The historical sources thus document the Church's obsession with incestuous marriages through legislation, propagation of fear of "pollution of the blood" and God's revenge, and denunciation. Only very rare cases of prohibited marriages among nobles were recorded (and those cases were surrounded by scandals and the weakening of the nobles' power). This suggests that the Church was quite effective in its enforcement of the MFP. In our empirical analysis, we establish a robust association between exposure to the Churches' MFP and the dissolution of kinship intensity both at the European regional (Section S4.4) and country level (Section S3.2).

\footnotetext{
${ }^{17}$ The Lex Salica was the Salian Franks' civil law code, first compiled around 500 by the Frankish King Clovis (51).

${ }^{18}$ The Visigothic king Reccared in Spain similarly passed legislation at the end of the $6^{\text {th }}$ century banning marriages with kin. The penalty was exile, annulment and transfer of property to the children. Legislation against incest is also found in the Lex Visigothorum around the mid- $7^{\text {th }}$ century (here, the penalty was not exile but forced entrance into the monastery).

${ }^{19}$ In Sections S4.2 and S4.4 we test whether there is evidence that the legacy of the Carolingian empire (under the reign of Charlemagne) impacted cousin marriages in the $20^{\text {th }}$ century and contemporary psychological variables. We demonstrate that the extent of the Carolingian empire under Charlemagne is robustly associated with lower cousin marriages in the $20^{\text {th }}$ century and higher generalized trust, fairness, individualism-independence and lower conformityobedience (exploiting regional variation within countries).
} 


\section{The Church's motivations for the MFP}

The motives behind the Churches' MFP and its successful implementation are multifaceted. Several hypotheses exist and most likely a combination of different factors lead to its differential implementation and success across different strands of Christianity.

The extent of the MFP, including banning kin-marriages, sororate and levirate marriage, polygyny, and discouraging adoption, cannot be traced to the Bible. Mitterauer (76) stresses that the MFP is in line with a Christian emphasis on the community (created by baptism) and an abrogation of genealogical descent. After all, Jesus surrounded himself with many unrelated disciples and this stance is also found in the Bible: "For I have come to turn a man against his father, a daughter against her mother, a daughter-in-law against her mother-in-law - man's enemies will be the members of his own household" (Mathew 10:35-36, $1^{\text {st }}$ century $\mathrm{CE})$ or "Someone told him [Jesus], 'Your mother and brothers are standing outside, wanting to speak to you.' He replied to him, 'Who is my mother, and who are my brothers?' Pointing to his disciples, he said, 'Here are my mother and my brothers. For whoever does the will of my Father in heaven is my brother and sister and mother." (Mathew 12:47-50). Moreover, the MFP fits with the Christian ideal of an ascetic lifestyle in which sexual relations are regulated. Early theologians argued for an extension of the biblical prohibitions. Basil (330-379) disapproved of marriage with the sister of one's wife, ${ }^{20}$ Ambrose (340-397) argued against uncleniece unions using an inbreeding argument, and Augustine (354-430AD), in his book "The city of God against the pagans", argued against kin-marriages by making a sociological argument: marrying outside the kin-group extends social relations and thus binds more people (93).

While these ideas existed early on, they do not suffice to explain the persistent implementation of the MFP by diverse clerics and secular rulers over centuries. It is doubtful that these scattered ideas by themselves, without aligning with the incentives of actors and organizations, could account for the success of the MFP. Moreover, this was not a uniform Christian development. Different Christian Churches developed different marriage regulations. We have outlined the development of the MFP for the Eastern and the Western Churches, but even within the evolving Western Church there were differences, with the Carolingian Empire enforcing the MFP most stringently. Other Churches, like the Celtic Church, only followed the prescriptions of the Old Testament. Coptic Christians were and still are allowed to marry cousins (while one's aunts, nieces and wife's sisters are taboo).

Ubl (51) argues that the Western Church's MFP is closely tied to powerful bishoprics, which formed an integral part of the Merovingian administration. Well-educated and recruited from the Gallo-Roman population (which constituted the majority of the kingdom's population), the bishops were patrons of the weak and poor, and supervised the clergy. Controlling marriage (by the threat of excommunication) allowed them to display and strengthen their position in relation to nobles and even the king. More broadly, the MFP helped to cement the Church's power in society by destroying clans, lineages and extended families. This helped propagate the religion and get rid of pagan rituals still practiced by Christian people. In fact, many clans had ancestor gods. Destroying clans and lineages demolished the foundation for ancestor gods.

At various points, Christian kings endorsed and incorporated the Church's MFP into secular law. On the one hand, this may have helped legitimize their roles as Christian kings by signaling their piousness and

\footnotetext{
${ }^{20} \mathrm{He}$ derives it from the bible in the following way: by sexual intercourse the couple becomes one flesh. By this the wife's sister becomes the husband's sister (similarly the wife's daughter and mother are out of question).
} 
reaffirming power over marriage legislation from the clergy. More importantly, however, the MFP allowed the king to protect himself against the emergence of powerful adversarial extended families, or dynasties in his Empire. Enforcing the MFP against other noble families thus strengthened the rulers power by weakening intensive kinship in favor of the state. For example, Chlodwig II ordered the execution of a Burgundian noble who had married his step-mother, which prevented the noble from becoming a powerful adversary. Charlemagne fostered the intermarriage between Saxon, Thuringian and Franconian nobles. The MFP could legitimize such an integrative policy on religious grounds. Another example is the extension of the MFP to sixth cousins that was initiated by German emperor Henrich II. Ubl (51) argues that this was directly aimed at weakening two of his adversaries to the throne. However, one longer term consequence is that since rulers were bound by the MFP as well it jeopardized their own dynasty. It may have been in times when dynasties were left without legitimate heirs that free cities and representative assemblies could assert more power (94).

Importantly, as the MFP fully unfolded, the Church reaped large financial gains. This point features prominently in the work of Goody $(25,69,70)$. At the time, property was most often held by a whole kinnetwork. Sororate, levirate and cousin marriages (and divorce or polygyny in the case of infertility) kept property within the clan, lineage or extended family. Destroying kin-networks, hindering adoption, and expanding the number of illegitimate children (in case marriage rules were not followed) left property without kin to inherit. Most often, people would will their property to the Church as a way of increasing their chances of getting into heaven in the afterlife. A helpful argument in favor of this action was a biblical quote in Matthew 19: "Again I tell you, it is easier for a camel to go through the eye of a needle than for a rich man to enter the kingdom of God." Thus, released from the pressures of the clan, a person with private property could increase their chance of getting a place in heaven by donating to the Church. And indeed, the Church became one of the biggest land holders in the medieval times. In the beginning of the $13^{\text {th }}$ century, when the grip on incestuous marriage loosened, the selling of dispensations - the right to marry someone within the forbidden degrees - became more common. This constituted an additional source of revenue for the Church (95). At the same time, the Church increasingly became the provider of social security (instead of kin-based systems), which further cemented its influence. Thus, while the financial motive may not have been the initial cause of the MFP it is likely the reason for its later success $(95,96)$.

The Church's MFP thus constitutes part of the success story of the Catholic Church. In addition, a changing psychology (fostering creativity, analytical thinking and entrepreneurial activity) and an increase in the scope of trust (which allowed for division of labor and trade expansion) may have contributed to the rise of the West and with it the expansion of the Catholic Church, making Christianity the largest religion in the world. Notable, about 85 to $90 \%$ of world's 2.1 billion Christians trace their cultural descent back to the Western Church, not through Christianity's many of other strands (like Armenian, Coptic, Syrian). The Church was so successful in implementing the MFP and creating a norm against incest that in today's Western societies, cousin marriage is hardly practiced even though the Protestant Church and secular rule do not forbid it (97). The spread of Christianity through its transformation of kinship and marriage and creation of a WEIRDer psychology may have eventually fostered the creation of new formal institutions, including representative governments, individual rights, commercial law and impersonal exchange (67, 71, 72, 97-99). 


\section{S2.2. Country-level indicator of medieval Church exposure}

We created two variables at the country level: one that captures a country's exposure to the Eastern Church's MFP and another that captures a country's exposure to the Western Church's MFP. We created these variables in three steps, for each country. First, we determined the starting point of the MFP within the area of what constitutes the country today. Second, we counted the years (up until year 1500) during which the country was governed by a Christian ruler. Finally, we created ancestor-adjusted indicators of the duration of the Churches' MFP using Putterman and Weil's (100) migration matrix to account for population movements post-1500. We use these ancestor-adjusted variables in all our analyses, in which we employ the measure at the country level.

For countries that were within the Western realm of Christianity prior to the ban and whose entire areas were governed by Christian rulers, we take the year 506 as the starting date for our variable that measures exposure to the Western Church' MFP (this is the case for France, Belgium, Luxembourg, Switzerland, and Italy). This Synod of Agde in Southern France, which banned cousin marriage, marks the start of many Synods in the area of what was to become the Carolingian Empire. ${ }^{21}$

For areas that were not under the influence of the Western Church at the time of the Synod of Agde, we start counting exposure to the Western Church's MFP at the time when the area was incorporated into the Church administration. We do this because the Church could only start implementing and enforcing their marriage rules once a Church administration existed (Section S2.1). In many cases, incorporation into the Church administration coincided with the establishment of a bishopric in the area. ${ }^{22}$ Exceptions are the Czech Republic and Slovenia, because these areas were initially under the administration of bishoprics with sees that lay outside of today's national boundaries (the Czech Republic under the bishopric of Regensburg and Slovenia under the archbishopric of Salzburg). Only later were bishoprics established within these countries. ${ }^{23}$ Another exception is Ireland, since it was initially under the influence of Celtic Christianity, which never implemented the MFP. For Ireland, we start the duration of the Church's MFP at the date when it was included in the Western Church's administration, which was at the beginning of the $12^{\text {th }}$ century (see Table S2.1).

\footnotetext{
${ }^{21}$ Regulations in the Roman Empire were in place before the year 506 due to Theodosius' cousin marriage prohibitions in 387. However, Theodosius' legislation against cousin marriage was quickly revoked in the Eastern empire and softened up in the Western empire and it is unclear if and how forcefully they were implemented. Due to the Great Migration leading to the fall of the Western empire, it is unlikely that the regulations could be forcefully and continuously implemented. The strong push for the MFP, which historians refer to as Medieval obsession, started with the Synod of Agde and continued in the area of what was to become the Carolingian Empire. Historical accounts of enforcement are found immediately after this Synod (51). We therefor choose 506 and not an earlier starting date.

${ }^{22}$ At the same time, the establishment of bishoprics in a newly Christianized area coincided with the adoption of the Christian religion by the ruling elite (and most often mass conversions in the population). The Church thus did not face oppression by rulers of a different religion.

${ }^{23}$ Further exceptions are bishoprics at the Adriatic coast of Balkan countries. As part of the Roman Empire, these areas were Christianized prior to the year 506. However, although the great migration destroyed the Church organization, some coastal bishoprics survived throughout this time (240). For these countries we take the point in time when the areas (now under the rule of Slavic and Germanic tribes) were re-included into the Church administration and ignore that some coastal bishoprics persisted.
} 
For both Church exposure variables, we only count those years during which an area was governed by a Christian ruler. This reflects that only when back-up by secular rulers the MFP could be implemented and enforced. For consistency we also apply this rule in case of the rule of the Golden Hord (following the Mongol invasion) in what constitutes Belarus, Russia, and the Ukraine even though the Golden Hord allowed a high degree of religious freedom. In cases in which a Church infrastructure already existed in parts of the country that were governed by non-Christian rulers, we take the year in which most of the area (of what constitutes the country today) was incorporated into the sphere of the Church as the starting point. For the Western Church's MFP, this is relevant for Spain and Portugal (where the Reconquista only occurred gradually, moving from North to South); Italy (where the South was influenced by the Byzantine Empire and the Orthodox Church, and Sicily was under Islamic rule)' and Germany (where parts of the West belonged to the Roman Empire and Christianized starting in the $4^{\text {th }}$ century, while Christianity did not arrive in the Northeast until the $13^{\text {th }}$ century). For the Eastern Church, this is relevant for all countries that fell under Ottoman rule. Thus, some imprecisions exist. For Western Church exposure it is possible to construct more precise regional measures based on radiuses around bishoprics at various points in time, and we do this below in Section S2.3. However, we don't have the necessary data to create a similar regional measure for Eastern Church exposure. Therefore, for the country-level analyses (which use both Eastern and Western Church exposure), we code both the Eastern and the Western Church exposure variables using the method just described. The start dates used for Western Church exposure are displayed in Table S2.2, while Table S2.3 gives information on Eastern Church exposure for each country. The dates follow the creation of bishoprics within the boundaries and are based on the same sources as described in the following Section S2.3 for countries in the realm of the Western Church. Additional sources are used in case of the Eastern Church and cited within Table S2.3. 


\begin{tabular}{|c|c|c|}
\hline Country & Year(CE) & Event \\
\hline Austria & 739 & $\begin{array}{l}\text { The diocese of Salzburg was founded in } 739 \text {. This archdiocese was the administrative center of } \\
\text { the Roman Catholic Church in Austria, initially covering an area that included eastern parts of } \\
\text { the country, including Vienna and Slovenia. }\end{array}$ \\
\hline Belgium & 506 & $\begin{array}{l}\text { The area of today's Belgium was part of the heartlands of the Frankish Empire. It was } \\
\text { Christianized as part of the Roman Empire when in } 380 \text { it became the official religion. In 506, } \\
\text { the Synod of Agde was the first Synod to forbid cousin marriage. }\end{array}$ \\
\hline $\begin{array}{l}\text { Bosnia and } \\
\text { Herzegovina }\end{array}$ & 1067 & $\begin{array}{l}\text { Bosnia was Christianized from the south and from missionary activity from the Hungarian } \\
\text { Kingdom in the North. Between the year } 1060 \text { and } 1075 \text { (most probably in 1067), the Diocese of } \\
\text { Bosna was founded. However, power struggles emerged between the Roman Catholic Church } \\
\text { and a Bosnian Church, leading to a schism in } 1255 \text {. Hungarian crusades initiated by the Pope } \\
\text { against the Bosnian Church around this time were not successful. Franciscan monks were settled } \\
\text { by the Pope to strengthen Catholicism (101). The Bosnian Church co-existed with a weak Roman } \\
\text { Catholic Church until the Ottoman Empire gained control over the region. This suggests that } \\
\text { Roman Catholic Christianity was not very firmly established. Under Ottoman rule, many } \\
\text { inhabitants converted to Islam or Orthodox Christianity as Catholicism experienced greater } \\
\text { repercussions in the Ottoman empire. Orthodox Christianity hardly existed in Bosnia } \\
\text { Herzegovina before 1500. Only the area of Zachlumia, which switched between Bosnia } \\
\text { Herzegovina and Serbia, was Orthodox. We exclude Bosnia from the analysis due to the } \\
\text { existence of the Bosnian Church. }\end{array}$ \\
\hline Croatia & 850 & $\begin{array}{l}\text { The first Church administration that was founded among the Croatians was the diocese of Nin in } \\
850 \text {. Even before this date, Croatia had been influenced by the Western Church and the } \\
\text { Carolingian Empire. Along the coast, bishoprics which originated in the Roman Empire still } \\
\text { existed. }\end{array}$ \\
\hline $\begin{array}{l}\text { Czech } \\
\text { Republic }\end{array}$ & 895 & $\begin{array}{l}\text { Bořivoj, the Duke of Bohemia, converted to Christianity around } 883 \text {. In } 895 \text {, Prague became part } \\
\text { of the Bavarian Roman Catholic diocese of Regensburg. In 973, a bishopric was established in } \\
\text { Prague. }\end{array}$ \\
\hline Denmark & 948 & $\begin{array}{l}\text { Bishoprics were erected by the Archdiocese of Hamburg-Bremen in the year } 948 \text { (Aarhus, Ribe, } \\
\text { and Slesvig). Odense was founded at some point before the year } 988 \text {. King Harald Bluetooth } \\
\text { converted to Christianity around } 960 .\end{array}$ \\
\hline Estonia & 1219 & $\begin{array}{l}\text { In 1193, Pope Celestine III called for crusades against pagans in Northern Europe. In 1219, a } \\
\text { diocese was founded in Reval. In 1227, Estonia was wholly conquered by Denmark and knights } \\
\text { of the Teutonic Order. }\end{array}$ \\
\hline Finland & 1209 & $\begin{array}{l}\text { The Christianization of Finland is ascribed to a crusade by Erik IX King of Sweden around the } \\
\text { year } 1150 \text { (the foundation of a diocese at Nousiainen is ascribed to around } 1156 \text { by historical } \\
\text { sources, but this date is subject to debate). While there is disagreement over whether the crusade } \\
\text { even happened, burial places that indicate a shift to Christianity took place in southern and south- } \\
\text { western Finland as early as the } 11^{\text {th }} \text { and } 12^{\text {th }} \text { centuries }(102) \text {. An unnamed bishop is first } \\
\text { mentioned by the Pope in } 1209 \text {. A second Swedish crusade took place around the year } 1249 \text {, } \\
\text { capturing the southern part of Finland. }\end{array}$ \\
\hline France & 506 & $\begin{array}{l}\text { France was Christianized as part of the Roman Empire. In 380, Christianity became the official } \\
\text { religion. In 506, the Synod of Agde in the south of France was the first Synod to forbid cousin } \\
\text { marriage. }\end{array}$ \\
\hline Germany & 734 & $\begin{array}{l}\text { The Christianization of large parts of Germany is closely associated with the missionary work of } \\
\text { Boniface (675-754). Parts of Germany (including the cities Aachen, Cologne, Fulda as well as } \\
\text { Swabia in the south west) belonged to Austrasia, the heartland of the Merovingian kingdom and } \\
\text { thus were already exposed to the MFP before Boniface's missionary work. A key event } \\
\text { associated with the Christianization of Germany is the felling of Thor's Oak in } 723 \text { near Fritzlar } \\
\text { by Boniface. Swabia (southwest) was already under Frankish rule by } 502 \text {. In Bavaria (southeast), } \\
\text { Christianity started to re-emerge around } 700 \text { when Boniface founded the diocese of Regensburg } \\
\text { (in 734). We take this as the starting date for the MFP because by then most of Germany was } \\
\text { within a Christian realm. In the northwest, the Massacre of Verden (782) forcefully converted the } \\
\text { Saxons to Christianity. Christianization in the northeast took considerably longer. The } \\
\text { northeastern area of Mecklenburg and Pomerania was only Christianized in the } 12^{\text {th }} \text { century. All } \\
\text { results hold when using } 782 \text { as the start date for the MFP instead of } 734 \text {. }\end{array}$ \\
\hline $\begin{array}{l}\text { England } \\
\text { (UK) }\end{array}$ & 597 & $\begin{array}{l}\text { The diocese of Canterbury was founded in } 597 \text {. Ethelberht of Kent was the first king to accept } \\
\text { baptism, circa } 601 \text { (but his sons returned to paganism). A decisive shift occurred in } 655 \text {, when } \\
\text { pagan King Penda of Mercia died in battle. Scotland, Wales and Cornwell practiced Celtic } \\
\text { Christianity, which did not ban cousin marriage. Scotland and Wales were incorporated into the } \\
\text { Roman Catholic administration in the } 11^{\text {th }} \text { century. Gerald of Wales, Archdeacon of Brecon } \\
(1146-1223) \text {, reports that incestuous marriages were common in Wales and Ireland }(103,104)\end{array}$ \\
\hline
\end{tabular}




\begin{tabular}{|c|c|c|}
\hline Hungary & 997 & $\begin{array}{l}\text { (Baptized) Stephen I became the ruler of Hungary in } 997 . \text { In the same year, the Ordinariate of } \\
\text { Pannonhalma was established, incorporating Hungary into the Western Church administration. } \\
\text { Bishoprics were established in Kalocsa (1000) and Pecs (1009). Additional } 11^{\text {th }} \text { century } \\
\text { bishoprics include Eger and Esztergom-Budapest. }\end{array}$ \\
\hline Iceland & 1056 & $\begin{array}{l}\text { According to the Heimskringla (an Old Norse kings' saga), Iceland adopted Christianity at their } \\
\text { governing assembly (Althing) in the year } 1000 \text {. The diocese of Skalholt was erected in } 1056 \text {. }\end{array}$ \\
\hline Ireland & 1101 & $\begin{array}{l}\text { Even though Christianization began in the } 5^{\text {th }} \text { century, Ireland developed a Celtic tradition in } \\
\text { which sororate, levirate and cousin marriages were not banned. In 1101, the reforming Synod of } \\
\text { Cashel tried to introduce the full requirements of the Roman Catholic Church. This and following } \\
\text { Synods also marked the transition of the Irish Church from a monastic to a diocesan and parish- } \\
\text { based church (allowing the enforcement of the newly-introduced ban on cousin marriage). }\end{array}$ \\
\hline Italy & 506 & $\begin{array}{l}\text { Italy has been Christian since the } 4^{\text {th }} \text { century. In the North, activity against cousin marriage, led } \\
\text { by Ambrose and St. Augustine, began at the end of the } 4^{\text {th }} \text { century. In 506, the Synod of Agde } \\
\text { was the first Synod to forbid cousin marriage. Further evidence for marriage prohibitions in Italy } \\
\text { is Pope Gregory the Great who emphasized the ban on cousin marriage in letters to Augustine, } \\
\text { bishop of Canterbury (597). However, the mainland South was under Langobard or Byzantine } \\
\text { rule, while Sicily experienced Muslim rule. The starting date of } 506 \text { therefore tends to } \\
\text { overestimate Italy's overall exposure to the Western Church's MFP. }\end{array}$ \\
\hline Latvia & 1186 & $\begin{array}{l}\text { The Diocese of Uexkuel was established in } 1186 \text { (renamed to Riga in 1202). In 1206, the } \\
\text { crusaders subdued the Livonian stronghold in Turaida. }\end{array}$ \\
\hline Lithuania & 1387 & $\begin{array}{l}\text { Following the baptism of Władysław II Jagiełło, Grand Duke of Lithuania, most of the court and } \\
\text { knights converted. The diocese in Vilnius was founded around } 1387 .\end{array}$ \\
\hline Luxemburg & 506 & $\begin{array}{l}\text { Luxembourg was part of the heartland of the Frankish Empire. It was Christianized as part of the } \\
\text { Roman Empire. In } 380 \text {, Christianity became the official religion. In } 506 \text { the Synod of Agde was } \\
\text { the first Synod to forbid cousin marriage. }\end{array}$ \\
\hline Malta & 1127 & Malta came under Christian rule when Roger II of Sicily established Norman rule in 1127. \\
\hline Netherlands & 695 & $\begin{array}{l}\text { In the south, the Franks became Christians in } 496 \text {. In } 734 \text {, the Frisians were defeated by the } \\
\text { Franks (though in the north, Christianization took longer). The first bishopric to be established } \\
\text { within the boundaries of modern day Netherlands was the diocese of Utrecht in } 695 \text {. }\end{array}$ \\
\hline Norway & 1015 & $\begin{array}{l}\text { In 995, Christian Olaf Tryggvason became King Olaf I of Norway. The Diocese of Nidaros } \\
\text { (Trondheim) was founded around the year } 1015 .\end{array}$ \\
\hline Poland & 986 & $\begin{array}{l}\text { In 966, Miesko I (first ruler of the Polish state) was baptized along with his court. The first } \\
\text { bishop was appointed in } 986 .\end{array}$ \\
\hline Portugal & 1147 & $\begin{array}{l}\text { In } 1147 \text { Christian crusaders captured the city of Lisbon. Most of Portugal was under Christian } \\
\text { rule by then. }\end{array}$ \\
\hline Slovakia & 880 & $\begin{array}{l}\text { The missionaries Cyril and Methodius arrived in Great Moravia in the } 9^{\text {th }} \text { century. The Diocese } \\
\text { of Nitra (the first bishopric within what constitutes Slovakia today) was established around } 880 \text {. } \\
\text { After the fall of Great Moravia, it was probably vacant until it was re-established in the } 11^{\text {th }} \\
\text { century. Around } 1000 \text {, the area was incorporated into the Kingdom of Hungary. Slovakia's } \\
\text { eastern territories belonged to the Diocese of Eger (founded } 10^{\text {th }} \text { century). }\end{array}$ \\
\hline Slovenia & 745 & $\begin{array}{l}\text { In 745, Carinthia submitted to Bavaria (which itself was a vassal of the Carolingian Empire). } \\
\text { This year is associated with Christianization by the Carantanian prince Borut. Christianization } \\
\text { was accompanied by uprisings. In 772, Bavarian Duke Tassilo III invaded Carantania and } \\
\text { installed a native Christian ruler. Slovenia was more fully incorporated into the Carolingian } \\
\text { Empire by Charlemagne in } 788 \text {, when it was under the Church administration of the Archdiocese } \\
\text { of Salzburg. While it retained internal independence, Frankish nobles were installed in } 828 \\
\text { following revolts. Slovenia did not have a bishopric in the territory that constitutes the country } \\
\text { today until } 1228 \text {. }\end{array}$ \\
\hline Spain & 1085 & $\begin{array}{l}\text { Spain was under Islamic rule starting in the year } 711 \text { but was gradually reconquered by Christian } \\
\text { rulers. In 1085, the Muslim Taifa kingdom of Toledo was conquered by Christian King Alfonso } \\
\text { VI of Leon and Castille. This brought large parts of what constitutes modern Spain under } \\
\text { Christian rule. }\end{array}$ \\
\hline Sweden & 990 & $\begin{array}{l}\text { The first attempts to set up a church in Birka occurred around 830. Another attempt, made by the } \\
\text { Archbishop of Hamburg, followed in 930. In 995, Olof Skötkonung, the first Christian king, } \\
\text { ascended the throne. The Dioceses of Skara (about 990), Vasteras (around 1055), Sigtuna } \\
\text { (around 1060), Lund (1060), and Uppsala (around 1080) were founded thereafter. Uprisings } \\
\text { against the new religions occurred around 1080. }\end{array}$ \\
\hline Switzerland & 506 & $\begin{array}{l}\text { Switzerland was part of the Burgundian kingdom. The region was Christianized as part of the } \\
\text { Roman Empire. In } 380 \text { Christianity became the official religion. In } 506 \text { the Synod of Agde was } \\
\text { the first Synod to forbid cousin marriage. }\end{array}$ \\
\hline
\end{tabular}




\begin{tabular}{|c|c|c|}
\hline Country & Year(AD) & Event \\
\hline Albania & 886 & $\begin{array}{l}\text { Albania was Christianized early on, but a Slavic invasion destroyed the Church organization } \\
\text { around } 600 \text { and rekindled paganism in the Hinterland. Following the iconoclast controversy } \\
\text { Northern coastal bishoprics of the Western Church were put under the Eastern Church's } \\
\text { administration in } 732 \text {. Around } 840 \text {, the territory that constitutes Albania today became part of } \\
\text { Bulgaria. The Bulgarian mission of Clemens of Ohrid Christianized the area. In 1019, the area of } \\
\text { Albania was ruled by Byzantium. The Schism of } 1054 \text { divided Albania, placing the south under } \\
\text { the administration of the Eastern Church, and the north under the administration of the Western } \\
\text { Church. While Catholicism subsequently spread in northern Albania, it remained a minority } \\
\text { religion among Albanians (105) The Ottoman Empire occupied most of Albania by } 1431 \text {. During } \\
\text { Ottoman rule, the majority converted to Islam. Mass conversion did not begin until the } 17^{\text {th }} \\
\text { century. }\end{array}$ \\
\hline Bulgaria & 870 & $\begin{array}{l}\text { In } 863 \text {, a mission from the Patriarch of Constantinople Photios converted Tsar Boris. Tsar Boris } \\
\text { had been willing to become Roman Catholic. As a response, Byzantium attacked and demanded } \\
\text { conversion to Eastern Orthodox. In 870, Bulgaria received an archbishopric (with the seat } \\
\text { initially being in Pliska) (106). The Ottoman Empire conquered Bulgaria in } 1396 .\end{array}$ \\
\hline Belarus & 992 & $\begin{array}{l}\text { According to historical sources the baptism of Kievan Rus' occurred in } 988 \text {. The diocese of } \\
\text { Polotsk was found around } 992 \text { within the borders of present-day Belarus }(107,108) \text {. From } 1237 \\
\text { to } 1240 \text { the Mongol invasion of Rus' occurred forcing all Rus' principalities to submit to Mongol } \\
\text { rule and becoming part of the Golden Horde empire from } 1380 \text { to } 1480 \text {. }\end{array}$ \\
\hline Cyprus & 688 & $\begin{array}{l}\text { Cyprus was Christianized in 380, when Christianity became the official religion of the Roman } \\
\text { Empire. Following an Arab invasion around 650, Cyprus was ruled jointly by the Arabs and } \\
\text { Byzantine Empire from 688-965. In 965, Cyprus was conquered by the Byzantine Empire. In } \\
698 \text {, the archbishop returned to Cyprus. In 1196, a Latin Church was established, although the } \\
\text { Roman Catholic population was mainly confined to some coastal cities. }\end{array}$ \\
\hline Greece & 692 & $\begin{array}{l}\text { Greece was Christianized in 380, when Christianity became the official religion of the Roman } \\
\text { Empire. In } 692 \text {, the Synod of Trullo forbade cousin marriage (51). In } 1453 \text { the Byzantium } \\
\text { Empire fell to the Ottoman empire. }\end{array}$ \\
\hline Macedonia & 870 & See Bulgaria (above) \\
\hline Moldova & 1359 & $\begin{array}{l}\text { The Principality of Moldova was founded in 1359, when it was incorporated into the Church } \\
\text { administration. }\end{array}$ \\
\hline Romania & 1234 & $\begin{array}{l}\text { The first mention of an administrative structure east of the Carpathians was made by the Pope in } \\
1234 .\end{array}$ \\
\hline $\begin{array}{l}\text { Russian } \\
\text { Federation }\end{array}$ & 991 & $\begin{array}{l}\text { According to historical sources the baptism of Kievan Rus' occurred in } 988 \text {. The following } \\
\text { dioceses were founded in the area of what constitutes Russia today: Rostov (around 991), } \\
\text { Novgorod (around 992) }(107,108) \text {. From } 1237 \text { to } 1240 \text { the Mongol invasion of Rus' occurred } \\
\text { forcing all Rus' principalities to submit to Mongol rule and becoming part of the Golden Horde } \\
\text { empire from } 1380 \text { to } 1480 \text {. }\end{array}$ \\
\hline $\begin{array}{l}\text { Serbia and } \\
\text { Montenegro }\end{array}$ & 870 & $\begin{array}{l}\text { Prince Mutimir was baptized in } 891 \text {. The Eparchies of Ras and Braničevo were founded in } 870 \text {. } \\
\text { The Serbian bishoprics became part of the Archbishopric of Ohrid after the Byzantine conquest } \\
\text { of the Bulgarian Empire in 1018. In 1459, Serbia fell to the Ottoman Empire. }\end{array}$ \\
\hline Ukraine & 988 & $\begin{array}{l}\text { According to historical sources the baptism of Kievan Rus' occurred in } 988 \text {. In the same year the } \\
\text { metropolitan of Kiev was founded }(107,108) \text {. From } 1237 \text { to } 1240 \text { the Mongol invasion of Rus' } \\
\text { occurred forcing all Rus' principalities to submit to Mongol rule and becoming part of the } \\
\text { Golden Horde empire from } 1380 \text { to } 1480 \text {. }\end{array}$ \\
\hline
\end{tabular}

Table S2.3 Start dates and background of Christianization and the Eastern Church's MFP in Europe at the country level.

We calculated the duration of each country's Church exposure up to the year 1500. We chose this cut-off for several reasons:

First, the implementation and strict enforcement of the MFP mainly occurred before the year 1500. According to historians, the strong enforcement, and even an obsessive fear of incest, occurred between the $6^{\text {th }}$ and the beginning of the $13^{\text {th }}$ century $(51,76,92)$. Following the year 1215 , dispensations and kin-marriages among royalty became more common. Thus, while restrictions still existed they were less strict than before.

Second, by the year 1500, all areas in Europe had been exposed to the Churches' MFP for a considerable amount of time. The norm not to marry cousins was thus most likely firmly internalized by 1500 . Changing 
kin-terms in European languages provide evidence of just how deep these changes were. ${ }^{24}$ Kin-terms changed in a chronological pattern that closely match the introduction of the Church's MFP and are consistent with a change towards exogamous marriage practices $(76,81)$. Further, evidence for the firm internalization is that Protestant areas did not revert to kin-marriage (or polygyny) despite the absence of religious prohibitions. Secular rulers in Protestant areas such as Sweden and protestant cities in Switzerland and Germany (109) put secular regulations against cousin marriage in place

Third, the year 1500 is also ideal for a practical reason. We wanted to calculate an indicator for the whole world that takes into account population movements. This is particularly important for countries that experienced a large inflow of European settlers. Putterman and Weil (100) created a migration matrix that captures migration between any pair of countries that occurred between the years 1500 and 2000. This allows us to compute our measures of exposure to the Churches' MFP by taking into account the exposure to the MFP of the average ancestor of a country's inhabitants. For our country-level analysis, we thus use the resulting ancestor-adjusted duration of exposure to the Eastern and Western Churches' MFP. This indicator reveals the average duration of the MFP (in centuries) that an individual's ancestors experienced. While we did code countries as either having Western, Eastern or no Church exposure before the year 1500, the migration matrix adjustment changes this. For example, migration of Russians into Estonia will increase Eastern Church exposure in Estonia.

One drawback of the cut-off for the year 1500 is that the areas of the Eastern Church were mostly occupied by the Ottoman Empire at the end of the $14^{\text {th }}$ and beginning of $15^{\text {th }}$ century. This period under non-Christian secular rule thus does not enter the indicator of Eastern Church exposure. In our analysis, we are not able to disentangle this from differences between the Eastern and Western Church's MFP. However, Schulz (98) has shown that differences between the Eastern and Western Church's MFP existed prior to the Ottoman conquest with regard to urban population growth, population growth, state formation and the creation of inclusive citylevel institutions. Figure S2.1 gives an overview of exposure to the Western Church's MFP, while Figure S2.2 does so for the Eastern Church's MFP.

\footnotetext{
${ }^{24}$ The observation that kin-terms reflect marriage practices is foundational to Anthropology research (see Section S1).
} 


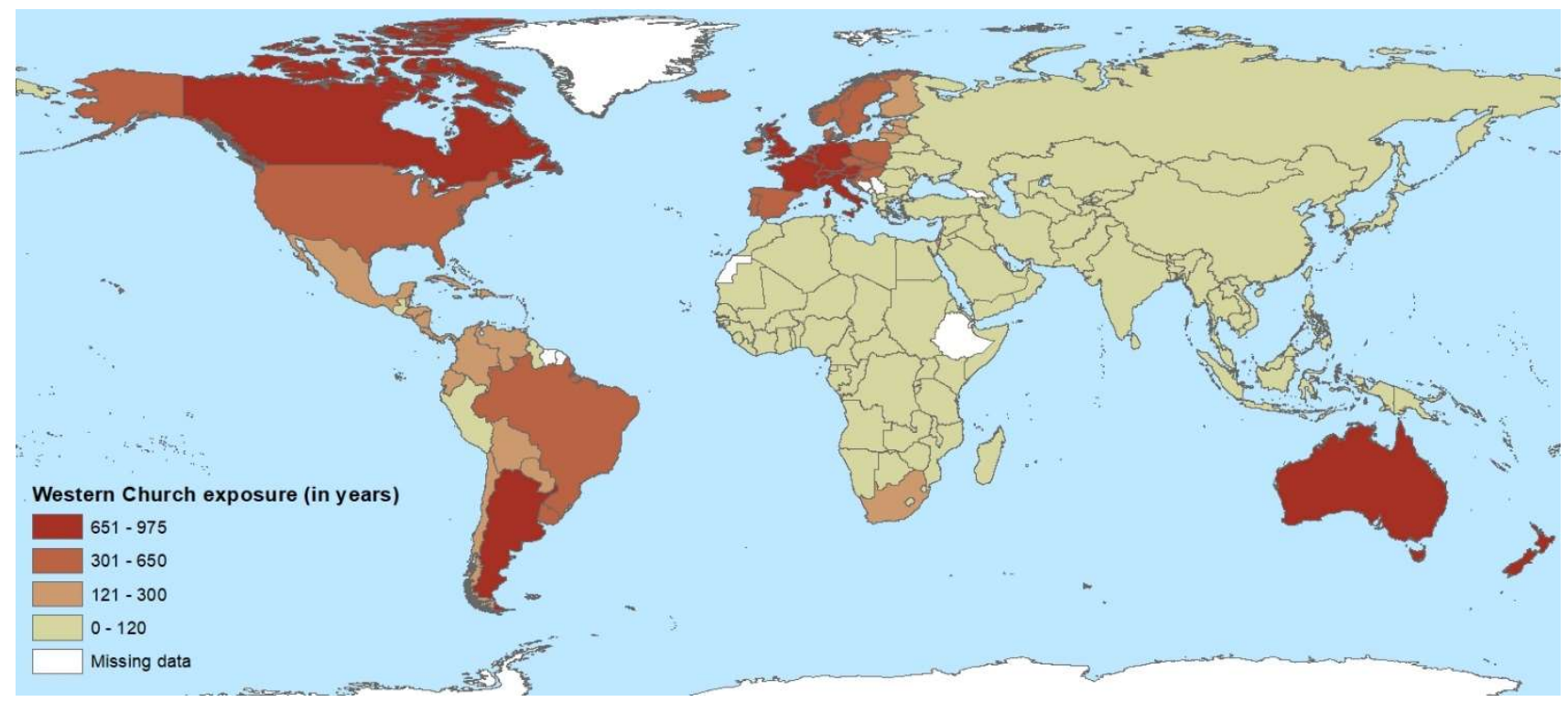

Figure S2.1 Western Church exposure. The indicator captures exposure between the years 506 to 1500. It is ancestor adjusted to reflect population migration that occurred after the year 1500 .

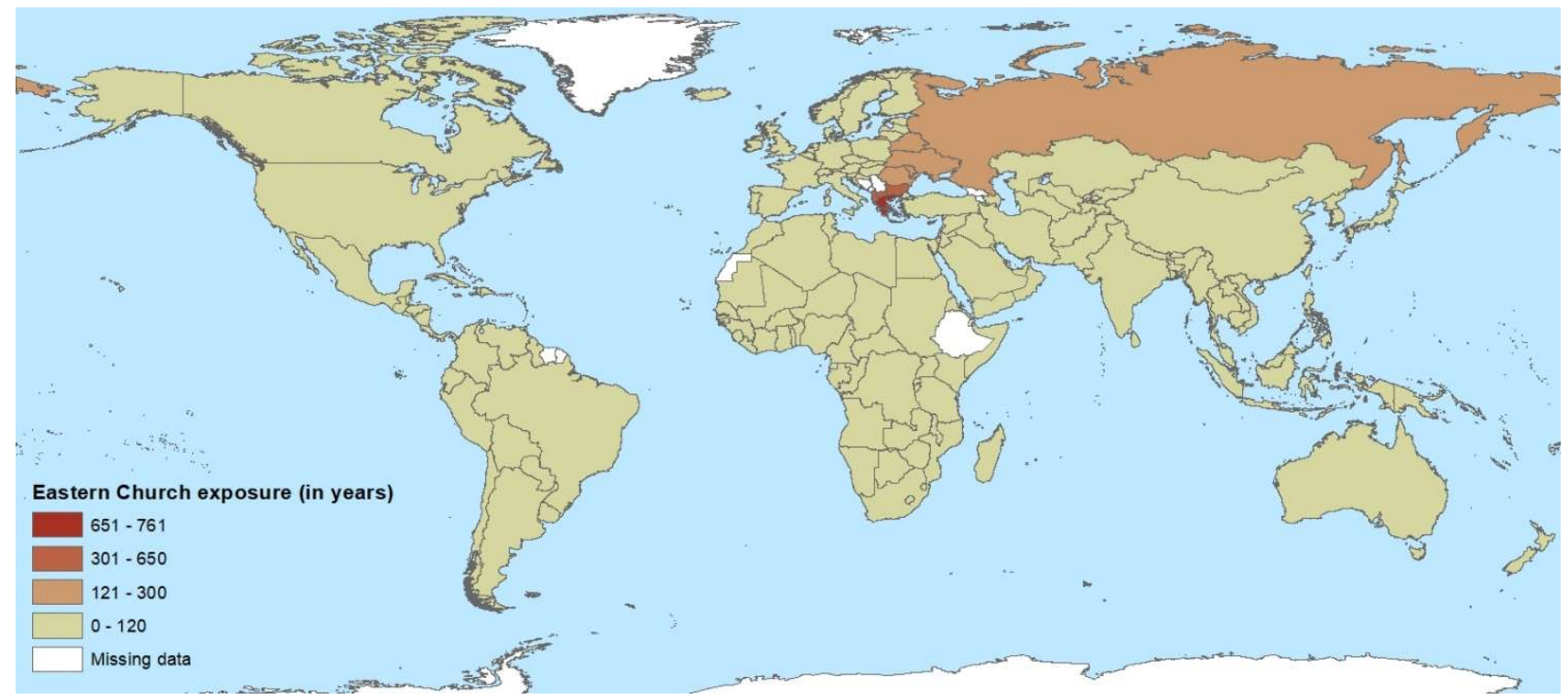

Figure S2.2 Eastern Church exposure. The indicator captures exposure between the years 692 to 1500. It is ancestor adjusted to reflect population migration that occurred after the year 1500. 


\section{S2.3. Regional indicator of medieval Western Church exposure}

In Section S2.2, we discussed country-level indicators that measure Western and Eastern Church exposure. Here, we look at regional variation in Western Church exposure. Based on the regions of the European Social Survey (ESS), we created a regional variable measuring Western Church exposure between the years 550 and $1500 .{ }^{25}$ We were not able to construct a similar measure for the Eastern Church due to data limitations. This regional indicator rests on the foundation and existence of bishoprics during this time span.

In a first step, we created a geo-coded data bank of the location, establishment and the duration of Western Church bishoprics' existence up to the year 1500. We relied on several data sources and did extensive crossvalidation checks. Our main data source is Catholic Hierarchy (http://www.catholic-hierarchy.org). For crossvalidation and as an additional source of information, we turned to GCatholic (http://www.gcatholic.org). Both sources are privately compiled and maintained websites (Catholic Hierarchy by David M. Cheney and GCatholic by Gabriel Chow) that contain detailed information on the foundation, suppression and reestablishment of bishoprics. A third source is Menestral ("Medievalists on the web" http://www.menestrel.fr), which contains similarly detailed data for a subset of countries. We checked the data provided in Catholic Hierarchy against GCatholic and Menestrel, and added any bishoprics that existed in those additional sources but not in Catholic Hierarchy. For the bishoprics present in more than one database, all three sources reveal a high level of consistency. Disagreements between the sources regarding the foundation dates was most often in the range of less than one or two decades - a rather small inaccuracy in relation to the duration of exposure to the Western Church's MFP up to the year 1500.

For a few bishoprics, only approximate dates (e.g. " $3^{\text {rd }}$ century", or "first half of the $3^{\text {rd }}$ century") were available. In these cases and as a further cross-validation, we turned to additional sources ((110) for Scandinavia or (111) for Europe), or resorted to more detailed internet searches. If the uncertainties could not be resolved, we used estimates by taking the middle year of the century of half century (e.g. the year 250 if the bishopric was founded in the $3^{\text {rd }}$ century, or 225 if the bishopric was founded in the first half of the $3^{\text {rd }}$ century.) These few uncertainties mostly occurred for bishoprics that were established before the beginning of the $6^{\text {th }}$ century, a time when the Church's MFP was absent or in its infancy. For each bishopric in our data bank, we added GIS-coordinates (a sub-set of which was taken from the Menestral data). ${ }^{26}$

Our data set only codes exposure to those bishoprics that existed in the realm of and were integrated into the hierarchical system of the Western Church. Certain areas are not coded as being exposed to the Church's MFP during certain time periods, despite the presence of bishoprics during those times. This was the case for areas that had bishoprics but were (i) under the control of the Celtic Churches, (ii) in Southern Italian Lombard kingdoms, Byzantine or Islamic territories, (iii) within Islamic areas of Portugal and Spain. For these areas, we began using bishoprics to code exposure to the Western Church only after they were

\footnotetext{
${ }^{25}$ Following the ESS-regions allows us to merge the regional MFP indicator to psychological variables based on the ESS. For the choice and harmonization of the ESS-regions see Section S4.

${ }^{26}$ For a small number $(<10)$, the exact location of the bishopric is debated. We picked the debated location for which we perceived the greatest consensus. In all cases, the distance between the debated locations is within a $50 \mathrm{~km}$ radius. Our exposure measure based on a $100 \mathrm{~km}$ radius, therefore suggesting a considerable overlap between alternative locations.
} 
integrated into the Western Church's administration and ruled by a Christian secular ruler. Further details are given below.

i. The Celtic Church only followed the marriage prohibitions stated in the Bible. It thus allowed sororate, levirate and cousin marriages. This changed at the first Synod of Cashel in 1101, when cousin marriage was discussed and disapproved, and the Celtic Church started to be integrated into the Catholic Church's realm. There are detailed lists of the formation and integration of bishoprics in Ireland, based on the Synods of Rathbreasail in 1111 (which set up the diocesan system) and the Synod of Kells in 1152 (which modified it). Similarly, we take Scottish bishoprics which were founded (and incorporated into the Western realm) in the $12^{\text {th }}$ century under the reign of King David I of Scotland even though bishoprics may have existed there before. ${ }^{27}$

ii. Like the Celtic Church, the Church in the Lombard duchies of Southern Italy was based on monasticism and lacked a hierarchical structure with a central role of bishoprics. Many bishoprics in the South were destroyed by the Lombard invasion ${ }^{28}$, and the remaining ones failed to establish or consolidate their power. They did not fill the same administrative function as bishoprics of the Carolingian Empire and were politically rather powerless. Bishops exercised almost no jurisdictional authority, local customs prevailed and "religious practices differed not only from one town to another but also from church to church" (Ramseyer (112), p. 8). The families or village communities who owned churches sometimes alternately appointed Latin (belonging to the Western Church) and Greek (belonging to the Eastern Church) priests, and the clergy continued to marry. Bishoprics were not integrated into the Western Church's hierarchy: Lombard Italian bishops in Southern Italy hardly participated in Roman Synods and were largely dependent on the secular Lombard rulers. ${ }^{29}$ Lombard kingdoms in the South recognized Byzantine hegemony, particularly in the years during which Byzantine power was at its height (880 to 960 (113)). ${ }^{30}$ Apart from Lombard rule, a large area of the Southern Italian mainland (with shifting borders over the centuries) was under Byzantine rule and the

\footnotetext{
${ }^{27}$ Incorporation started under Margaret of Scotland (1046-1093AD), who was raised in England, within the realm of the Western Church. An undated Scottish Synod (probably around 1090) is associated with Margaret pushing back on Celtic traditions and condemning marriage with one's step-mother and widow of one's brother (241).

${ }^{28}$ In the South Italian duchies of Spoleto and Benevento, only about ten out of several hundred bishoprics still existed in the year 700 (113). However, some of our data sources list more bishoprics in Southern Italy at this point in time. While the data sources are reliable for the foundational dates of bishoprics, they are generally less reliable regarding when bishoprics where destroyed by invading forces. Partly, this reflects that sees that were destroyed often continued to exist as titular sees, in which case the bishop no longer resided at the original location.

${ }^{29}$ Only in the late $10^{\text {th }}$ century did the archbishopric of Salerno slowly begin constructing an autonomous ecclesiastical system based on parish rights, Papal over-lordship and Roman canon law. Archbishops and bishops began to claim authority over a system of churches within their diocese, including the right to appoint priests, discipline clergy, and control ecclesiastical revenues, and turned more and more to the Papacy, rather than Lombard princes, for privileges, support, and aid (112). Yet, this was a slow process often in conflict with the Byzantine Empire's interests (242). The main incorporation into the Western Church hierarchy occurred after the Norman conquest as synodal activity by the pope attests.

${ }^{30}$ The Lombard laws of Rothari and of Liutprand (kings of the Northern Italian Lombard kingdom) were also produced and circulated in Lombard Southern Italy. The Edictus Rothari of 643 prohibited marriages to one's stepmother, stepdaughter, or sister-in-law. In 723, the Laws of Liutprand contained prohibitions against marriage to one's brother's wife, cousin's widow, goddaughter, godmother, or godfather's daughter.
} 
influence of the Eastern Church, with its diluted and weakly-enforced MFP ${ }^{31}$. Meanwhile, Sicily (and some temporary holdings on the mainland) were under Islamic influence. The above evidence suggests that Southern Italy did not experience the Western Church's MFP until it started to be integrated into the Western Church's hierarchy in the $11^{\text {th }}$ century. We begin including Southern Italian bishoprics after the Norman invasion. Following this invasion, Lombard and Byzantine Southern Italy and Islamic Sicily were integrated into the realm of the Western Church.

iii. For Spain and Portugal, we begin counting Western Church exposure in the year during which the see's location was reconquered by the Reconquista.

The Western Church's bishoprics of the Balkans are included in the data set even though there is ambiguity regarding their degree of incorporation into the hierarchy of the Western Church. Following the Synod of Trullo and the Iconoclast controversy (in the $8^{\text {th }}$ and $9^{\text {th }}$ centuries) the jurisdiction over the Eastern Balkans (or the Eastern part of the ancient Roman province of Illyricum) was contested between the Western Church and the Byzantine emperor, who strove to put them under the jurisdiction of the Patriarch of Constantinople (114). We only include Albanian bishoprics once the Western Church revived bishoprics after the Schism of 1054 (105). Moreover, Slavic migration into the Balkans in the $7^{\text {th }}$ century destroyed existing Church infrastructure. Only coastal bishoprics, which had no significant influence into the country-side survived. Our measure, which is based on a $100 \mathrm{~km}$ radius, reaches into the hinterland and thus overestimates regional Church exposure in the Balkans.

Our final data set contains 896 geo-located bishoprics that existed in the Western Church's realm at some point prior to the year 1500, along with the dates of their foundation. Figure S2.3 gives an overview of the distribution of bishoprics at three points in time: 500, 1000, and 1500.

\footnotetext{
${ }^{31}$ Between the years 732 and 757, the Byzantine Emperor attached the Hellenized territories of Sicily, Southern Italy and probably Eastern Illyricum to the jurisdiction of the Patriarchate of Constantinople.
} 

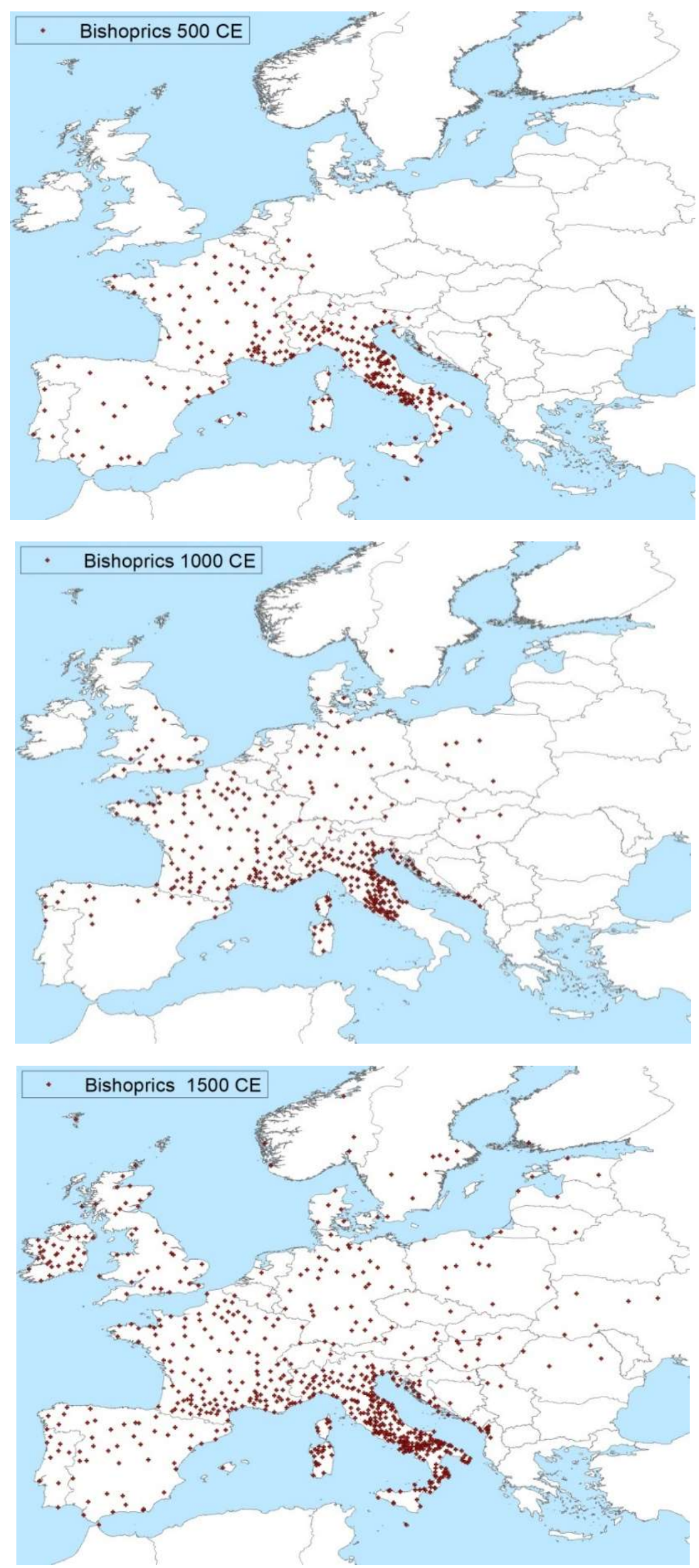

Figure S2.3: Bishoprics in the Western Church in the years 500, 1000, and 1500. 
The regional Western Church exposure indicator is based on GIS data of these 895 bishoprics. To calculate the Church exposure at the regional level, we first divided Europe into pixels of $0.125 \times 0.125$ decimal degrees (about 14 by 14km at the equator; in Sweden at the latitude of Stockholm these pixels are about 14 by $7 \mathrm{~km}$ ). For each pixel in each half-century from the year 550 to the year 1500 , we calculated the distance to the nearest bishopric. ${ }^{32}$ In a given half-century, a pixel was assigned the value of "1" if there was a bishopric within $100 \mathrm{~km}$ of the pixel's centroid; the pixel was otherwise coded as "0". Subsequently, we summed each pixel's exposure over all half-centuries (and multiplied it by 50), yielding a measure of the duration of the pixel's exposure to the Western Church's MFP in years:

$$
\operatorname{Exp}_{i}=50 \cdot \sum_{t=550}^{t=1500} \text { Cell }_{i, t}, \text { where Cell } \text { C }_{i, t}=\left\{\begin{array}{l}
0 \text { if dist } B_{i, t}>100 \mathrm{~km} \\
1 \text { if dist } B_{i, t} \leq 100 \mathrm{~km}
\end{array}\right.
$$

where $t$ indexes the half-centuries and increases in 50-year intervals, $i$ indexes the pixels, and $\operatorname{dist}_{i, t}$ is the distance between pixel $i$ 's centroid and the nearest bishoprics at half-century $t$. $\operatorname{Exp}_{i}$ can thus range from 0 to 1000 .

Next, for each ESS region $r$, we calculated the region's Church exposure by taking the mean $\operatorname{Exp}_{i}$ across all the pixels that fall into the region: $\operatorname{Exp}_{r}=\operatorname{Mean}\left(\operatorname{Exp}_{i} \mid i \in r\right)$. $\operatorname{Exp}_{r}$ can thus range from 0 to 1000 . A regional exposure of 0 implies that in no half-century between the year 550 and 1500 was there a bishopric within $100 \mathrm{~km}$ of any pixel within the region; a regional exposure of 1000 implies that in all half-centuries, all pixels within the region were within $100 \mathrm{~km}$ of a bishopric.

Figure S2.4 gives an overview of Church exposure in the regions of Europe. Since the regions are based on the ESS, they vary in size. That is, some countries have more finely grained regions (and we hence have more observations relative to the surface area) compared to others. For example, the ESS regions in the Netherlands are considerably more finely grained than those in Germany.

The distance of $100 \mathrm{~km}$ is informed by two considerations. First, Reyerson $(115)$ estimates that $14^{\text {th }}$ century horseback travel in Italy could cover 50 to $60 \mathrm{~km}$ a day. Based on this estimate, it would have taken up to two days of travel to reach a bishopric $100 \mathrm{~km}$ away. This travel time suggests that a $100 \mathrm{~km}$ radius was well within reach of a bishopric.

Second, we focused on what percentage of pixels in the realm of the Western Church was covered by bishoprics in 1500. At a point in time when the whole of Europe was Christianized and administered by the Church, this criterion is informative on the geographic extent of bishoprics' jurisdiction. A $100 \mathrm{~km}$ radius covered $65 \%$ of the pixels that fall within today's countries that fully belonged to the sphere of the Western Church. While this figure is not particularly high, this is largely due to Scandinavia and its large sparsely populated northern regions. Excluding Sweden, Finland and Norway increases overall coverage to $88 \%$ of pixels.

\footnotetext{
${ }^{32}$ Note that starting with the year 550 is consistent with our country-level indicator, which starts at the year 506 . The reason is that the regional Church indicator is based on half centuries. E.g. if a pixel takes the value of 1 for the year 550, it can be interpreted as if a bishopric existed between 501 and 550. It therefore approximates the duration.
} 
Inevitably, though, our measure is imperfect. One drawback of the $100 \mathrm{~km}$ radius is that it does not take political borders into account. For example, while there was a political border in Italy between the Lombard kingdoms in the South and the Carolingian Empire ${ }^{33}$ in the North (or in Spain and Portugal between Islamic and Christian areas), this is not picked up by the $100 \mathrm{~km}$ radius. Conversely, some bishoprics covered larger areas than implied by the $100 \mathrm{~km}$ radius. Figure $\mathbf{S 2 . 4}$ reveals that some regions that were undoubtedly exposed to the Western Church (e.g. in the Netherlands and Scandinavia) are coded as having no Western Church exposure, which similarly stems from the mechanistic coding. Other examples are the Archdiocese of Salzburg, which reached as far as Vienna and Slovenia, and the bishopric of Regensburg, which incorporated parts of Bohemia as far away as Prague. Despite these limitations, the $100 \mathrm{~km}$ radius nevertheless acts as a good a proxy for Church exposure. We conducted robustness checks to demonstrate that all results hold for smaller $(75 \mathrm{~km})$ or larger radiuses $(125 \mathrm{~km}, 150 \mathrm{~km}, 175 \mathrm{~km}, 200 \mathrm{~km}$; see Section S4.1).

We also constructed a population-weighted measure addressing concerns that the indicator may give too much weight to unpopulated pixels within a region. We did this by assigning less weight to pixels in which there is no population when aggregating to the regional level. The weights are based on pixel-level population estimates for the year 500, taken from $(116,117))$; these population estimates are based on geographic factors and assign higher population density to areas that are more easily reached, such as areas close to rivers or far from mountains. The correlation between the non-population-weighted and population-weighted indicator of Church exposure is high: 0.9974. Not surprisingly, all results hold with the population-weighted indicator with point estimates generally being larger in magnitude and exhibiting higher significance levels.

\footnotetext{
${ }^{33}$ In Sections S4.2 we examine the association between regions that were exposed to the Carolingian Empire (the area constituting the forerunner in implementation and enforcement of the MFP) and psychology. In this case, the borders are more precise. Boarders of the Carolingian Empire also capture that Brittany was not part of the Empire but was instead strongly influenced by the Celtic Church up until around the $8^{\text {th }}$ century. Since we do not have a precise date for when the influence of Celtic Church over bishoprics in these regions vanished, this is not picked up by our regional Church exposure indicator.
} 


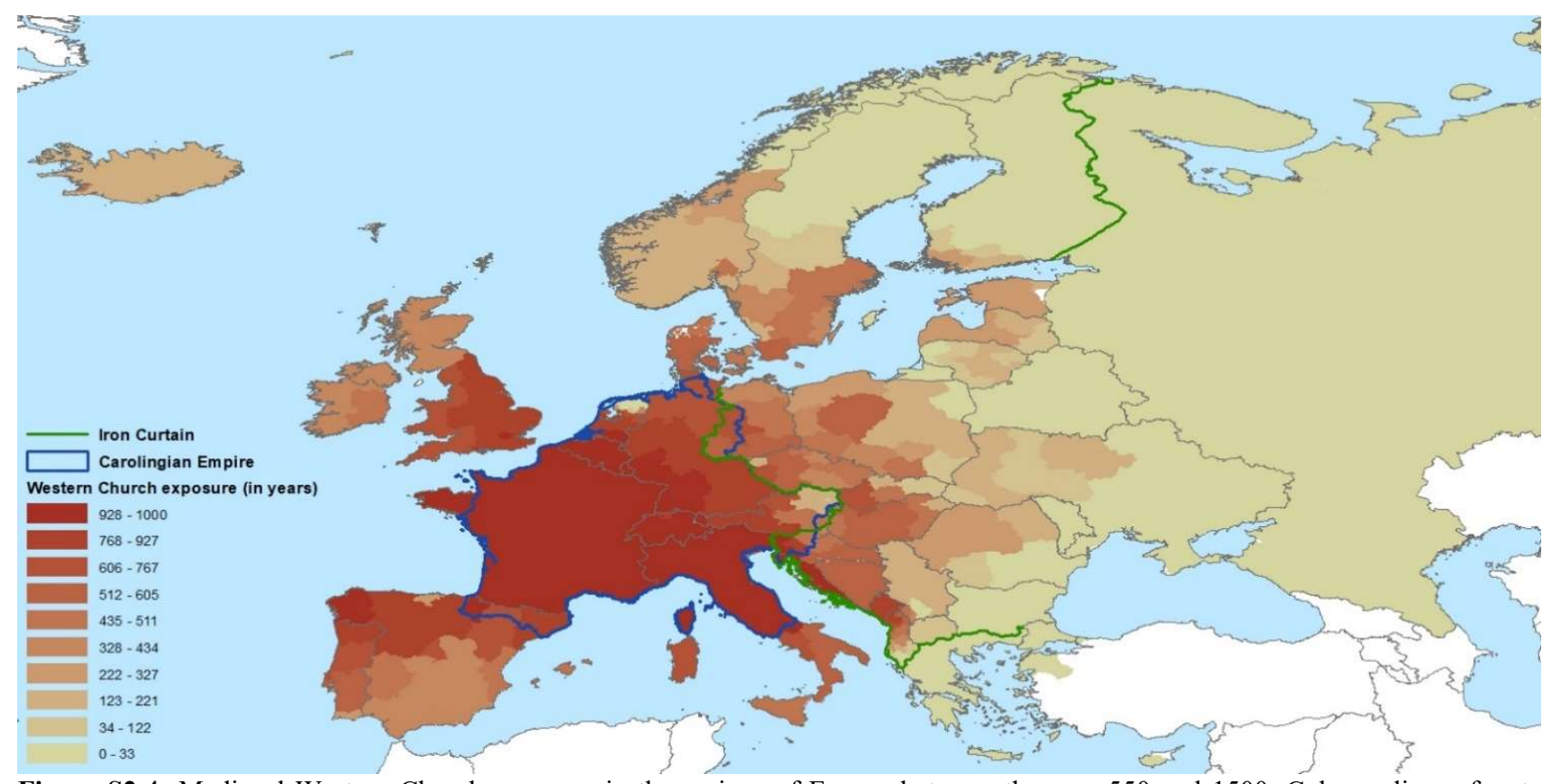

Figure S2.4: Medieval Western Church exposure in the regions of Europe between the year 550 and 1500 . Color coding refers to Church exposure based on bishoprics. The map shows the boundaries of the Carolingian Empire (blue line, according to Shepherd (118)) and the divide between Western and Socialist Europe during the Cold War (green line - we coded the countries that constituted the former country of Yugoslavia as Socialist even though they were not part of the Warsaw pact. This follows Churchill's original (1948) statement on the "Iron curtain".) The ESS contains 36 countries; the map contains the Medieval Western Church's exposure indicator for all of Europe, including countries that are not included in the ESS. 


\section{PART II: EMPIRICAL ANALYSIS}

\section{Overview}

A growing body of research documents that populations around the globe vary substantially (on average) along several important psychological measures (11,90-103, non exhaustive). A large body of psychological research finds that people's motivations, emotions, perceptions, thinking-styles and other aspects of cognition are heavily influenced by the social norms, technologies and linguistic worlds they encounter while growing up $(7,39,130,133-151)$. Informed by those insights we hypothesize that kinship intensity impacts human psychology. The psychological differences documented here may thus arise from the action of a combination of facultative, developmental and cultural-evolutionary mechanisms $(146,152-156)$ in response to the incentives created by intensive kin-based institutions. Here we give a brief overview on all the analyses we undertook to establish a robust link between (i) kinship intensity and human psychology; (ii) the reducedform relationship between Church exposure and human psychology; and (iii) Church exposure and kinship intensity.

We employ several approaches to address potential confounding factors that could drive the association between kinship intensity, Church exposure, and human psychology. First, throughout our analyses, we carefully control for variables that could potentially bias our estimates and which previous literature has demonstrated to be important predictors of cross-societal variation in human psychology. Our baseline control variables consist of a set of bio-geographic conditions. Our strategy has been to "tie our hands" and use these baseline controls for all levels of analysis, whenever possible. In addition, we aimed to report similar or identical dependent variables at all levels of analysis. These two procedures, consistently using the same covariates and reporting all regressions (in contrast to only a selected subset) for the large set of dependent variables, together give a full picture of the statistical associations.

Our second approach has been to employ different methodologies and examine the associations at various levels of analysis: across countries (Section S3), across European regions (Section S4), across Italian provinces (Section S5), among individuals within Europe using only children of immigrants (Section S6), and within countries using the ethnic ancestry of individuals (Section S7).

Third, throughout our analyses, we also report a suite of robustness checks. These include alternative specifications of our explanatory variables, standard errors adjusted for spatial autocorrelations, additional control variables, or analyses based on sub-samples. Throughout, we report the significance levels of two-

sided tests $(*: P \leq 0.1, * *: P \leq 0.05, * * *: P \leq 0.01$ ). (By contrast, in the main text we report the significance levels on one-sided tests.) Since we test directed hypotheses, this is a conservative way of reporting p-values. As such, these $P$-values can be re-interpreted as reporting the following values of one-sided tests: *: $P_{\text {one- }}$ sided $\leq 0.050, * *: P_{\text {one-sided }} \leq 0.025, * * *: P_{\text {one-sided }} \leq 0.005$.

In the following, we sketch each section:

- Section S3 analyzes cross-country data. A big advantage of the country-level analysis is that a large number of cross-country psychological dependent variables is available. Apart from survey-based 
attitudinal measures, we analyze behavioral indicators developed by experimental economists and psychologists as well as ecologically more relevant measures, such as blood donations and parking ticket violations among diplomats in New York. We demonstrate robust associations between kinship intensity and these outcome variables, as well as robust reduced-form associations between Church exposure and these variables (Section S3.1). Further, Section S3.2 reveals a robust association between Church exposure and kinship intensity.

- Section S4 demonstrates that the associations also hold across European regions. In addition to the usual set of controls, this analysis controls for country fixed effects, thus ruling out estimation bias due to potentially unobserved factors that vary across countries, like national culture, history, infrastructure, and national-level formal institutions. Since this analysis establishes that withinEurope regional variation is predictive of psychological outcomes, it is evidence that our crosscountry results are not driven by an (omitted) European factor.

- Section S5 turns to an analysis of the association between kinship intensity and blood donations across Italian provinces. This allows us to demonstrate that an ecologically relevant dependent variable (blood donations) is significantly associated with kinship intensity within a single country. This analysis rests on even more finely grained variation of kinship intensity and is likewise robust to controlling for an extensive set of covariates.

- Section S6 follows the epidemiological approach and exploit variation in the ancestral background of the children of immigrants in European countries. The idea behind this epidemiological approach is that children of immigrants, who were born in the same country, face the same societal-level environment when growing up but differ in their cultural heritage $(157,158)$. In principle, this approach removes one important source of potential bias in the estimates - bias due to the societallevel environment in which the children grew up (such as national formal institution, schooling, infrastructure, geography, and climate). The estimates are thus intended to only capture vertically transmitted cultural features. We demonstrate that kinship intensity of the parents' origin country or ethnicity is predictive of human psychology. Our analysis goes beyond the standard approach: we demonstrate that this relationship is robust to controlling for origin country fixed effects, resident region fixed effects, and many other features of the ethnic background.

- Section S7 exploits within-country variation in ancestral ethnicities' kinship intensity and find significant relations with human psychology. This analysis uses data from the World Value Survey (WVS) from many countries around the world. Like the analyses reported in Sections S4 and S5, it leverages within-country variation; but unlike those analyses, it is not confined to Europe. Here, too, kinship intensity is predictive of psychological outcomes.

\section{Potential endogeneity}

The different levels of analysis reveal evidence that kinship intensity impacts human psychology. Clearly, each analysis in itself cannot address all concern about endogeneity. However, in their entirety, they give a strong indication that (i) kinship intensity impacts human psychology and (ii) the Churches' MFP affected 
human psychology through its influence on kinship intensity. In the following, we discuss several features of our overall empirical approach that mitigate the possibility that our results are an artefact of reverse causation or omitted variable bias.

We analyze "deep" explanatory variables, thus ruling out reverse causality and estimation bias due to contemporary factors. An important feature of our study is that both the Kinship Intensity Index (KII; defined in Section S1) and Church exposure are "deep" variables. That is, the KII is based on the Ethnographic Atlas, which aims to capture characteristics of ethnicities before the onset of the Industrial Revolution or European contact. Church exposure is measured up to the year $1500 \mathrm{CE}$ - long before the Enlightenment or the onset of the Industrial Revolution. Thus, the indicators are not influenced by contemporary factors, which rules out reverse causality or estimation bias due to modern day institutions, infrastructure, technology, colonial history and other factors related to the Industrial Revolution or the European Expansion. ${ }^{34}$ Moreover, Western Church exposure occurred before the Enlightenment or the Reformation ruling out an effect of those events on our explanatory variable. In fact, the Enlightenment may have rather been the result of the changing kin structure and a more individualistic psychology in Europe. Our analysis thus establishes historically deep origins of human psychology.

Yet, this does not preclude that some other (even deeper) unobserved factors may have shaped both kinship intensity and human psychology or that some other element of the Church may be the decisive factors for the observed psychological differences. Here we first discuss endogeneity due to other deep variables (1). In a second step, we discuss to what degree Church-related factors other than the MFP can explain the relationship between Church exposure, kinship intensity, and human psychology (2).

\section{(1) Endogeneity due to other deep variables}

Several features of our analyses mitigate the possibility that deep bio-geographic factors bias our estimates.

(i) We control for bio-geographic conditions. Research hast started to link bio-geographic conditions to human psychology $(122-124,159-165)$. Here we control for bio-geographic conditions that may have impacted both kinship intensity and human psychology through various channels (e.g., agricultural practices, parasite prevalence, remoteness, genetic heterogeneity) and that previous research have discussed as important factors for human psychology.

(ii) The analyses using the children of immigrants addresses potential estimation bias due to environmental factors at the societal or regional level (see Section S6). Children of immigrants, who grew up in the same environment, vary in their cultural background. The analysis is therefore intended to only capture vertically transmitted cultural values $(157,158)$. For example, this rules out estimation bias due to a direct effect of geographic features. In several regressions specifications, we control for origin country fixed effects and many characteristics of the immigrants' ancestral

\footnotetext{
${ }^{34}$ Our third variable captures $20^{\text {th }}$ century cousin marriage practices. It is therefore not a particularly deep historical variable; however, it is highly correlated with the KII (Spearman's $\rho=0.71, \mathrm{~N}=73, P<0.001$ ) and the percentage of people within a country speaking a language that differentiate cousin terms (Spearman's $\rho=0.84, \mathrm{~N}=73, P<0.001$ ), suggesting that it may have deep origins, and further pointing to the high persistence of kinship intensity.
} 
ethnicity. This mitigates the possibility that some other cultural or origin country factor that is vertically transmitted biases our estimates.

(iii) Exposure to the Churches' MFP. In our analysis we detail the role of Church exposure in dismantling intensive kinship structures in Europe. We therefore offer an explanation for the observed differences in kinship intensity that rest on a set of human-made rules. These human-made rules do not need to rest in subsistence style or deep geographic conditions. And indeed, the historic account suggests a large idiosyncratic component in the spread of Christianity and therefore the MFP (see below). Due to forced, top-down Christianization and shifting spheres of influence following wars, which in medieval times carried a large random component, in some ways one can view the duration of medieval Church exposure as a natural experiment. This suggests that the Church's MFP disconnected kinship intensity from agricultural practices or geographic conditions more generally.

We report robust evidence that Church exposure - bringing a culturally propagated set of rules regarding marriage - changed kinship intensity (Section S3.2 and Section S4.4). Evidence that we do not just capture a European confound in the cross-country analysis comes from Section S4, which demonstrates a robust association between Church exposure, kinship intensity and human psychology. The analysis rests only on Europe and contains country fixed effects. This rules out that a more general unobserved European factor explains the association between the MFP and Western, Educated, Industrialized, Rich, and Democratic (WEIRD) psychology, as well as estimation biases due to unobserved cultural effects at the country level. The within-country variation of Church exposure is further evidence of its random element. For example, more culturally homogenous people like Germanic tribes, which later formed a single country, did not simultaneously adopt Christianity. Rather, the adoption of Christianity was the result of a long, violent struggle and many wars.

Nevertheless, empirically we cannot rule out that the spread of Christianity, kinship intensity and human psychology is confounded by an omitted factor (for a discussion of other Christian factors that simultaneously affect kinship and psychology, see below). However, the historical account suggests that the dosage of Church exposure an area experienced carries a large random component. Examples abound:

- The conquest of the Hispanic peninsula by the Islamic Umayyad dynasty was only halted in France by Charles Martel. Historical sources attribute Charles Martel's victory over the Umayyads to rumors spread among the Umayyad warriors that their spoils were plundered, which made them leave the battle field. This is thus an event that carries a large idiosyncratic component. The subsequent Reconquista lasted almost 8 centuries, creating considerable variation in Church exposure in Iberia.

- Sicily switched from Christian to Islamic rulers and then back.

- Similarly, the expansion of the Carolingian Empire, with its strict enforcement of anti-incest legislation, was driven by outcomes of various wars. The Saxons in Northern Germany were forcefully subdued and Christianized. Historical sources associate the Carolingian emperor 
Charlemagne with the killings of around 4500 Saxons, who did not want to convert to Christianity. The Spanish March (in the northeast of Spain) was forcefully created by the Carolingian Empire (while further incursions into the Hispanic peninsula were halted). The Carolingians incorporated Northern Italy into their Empire after defeating the Lombards. ${ }^{35}$

- Holy Roman Emperor Otto I's victory against the (then pagan) Hungarians in 955 is attributed to rain, as this hindered the Hungarians from using their bows. Eastward expansions in the Northeast of Germany after Otto I's victory at the battle on the Raxa in 955 were halted by the Slavic revolt 983 for almost 200 years.

- A crusade against the Wends in Northeastern Germany and the Baltic people of what constitutes Estonia, Lithuania and Latvia today, the last remaining non-Christian areas in Europe, was called in 1195 . It took up to the end of the $14^{\text {th }}$ century to conquer and convert the population. Similarly, Finland's Christianization is associated with Crusades from Sweden.

- In addition, conversion to either the Eastern Orthodox or Western Latin Church likewise carries a substantial random component. According to legend, Prince Vladimir of the Kievan Rus considered the Eastern, Western, and Islamic religions before deciding on the Eastern Orthodox Church. Bulgarian Zar Boris I wanted to turn to the Western Church; but, defeated by Byzantium, he was forced to choose Eastern Orthodoxy. The historical accounts thus suggest that decision for the religion was driven by proximate considerations and populations were not endogenously selecting into one or the other form of Christianity. Most often, the decision for or against either form of Christianity was made by a secular ruler, who was most likely governed by immediate political considerations.

- In areas where Christianity was not brought by a foreign military force, Christianization and the imposition of its rules were most often top-down enforced by the newly conversed rulers (e.g. in Poland, Bohemia, Kievian Russ). Thus, the choice of religion largely rests on the decision of the ruler and ordinary people did not have much of a say. In almost all of these cases this top-down Christianization was accompanied by uprisings. This suggest that there was not a general strong trend within the population to convert to Christianity, rather that it was the outcome of rulers driven by proximate political considerations.

While this historical evidence highlights the random, idiosyncratic component in the spread of Christianity, empirically we cannot fully rule out that an unobserved factor might have influenced the Church to prioritize its Christianization efforts in specific areas. ${ }^{36}$ Also, the ability of the Church to successful Christianize a population may vary. Controlling for a large set of covariates mitigates these

${ }^{35}$ The attempts of Louis II, great grandson of Charlemagne, to incorporate Southern Italy into the Northern Kingdom failed even though he established military power. He failed because he was betrayed by an ally. This demonstrates again how an idiosyncratic event that does not rest on military strength can have long lasting implications.

${ }^{36}$ Evidence against the notion that pre-existing factors fostered Christianization and thus bias our estimates comes from Schulz (98). Exploiting a panel data set, he demonstrates in a diff-in-diff analysis (with city fixed effects and controls for other time trends) that Church exposure is predictive of the formation of city-level inclusive institutions. This association thus cannot be explained by time-invariant factors like preexisting cultural, geographic, or genetic differences. 
possibilities. Clearly though, the Church's ideology was to Christianize the entire world. And indeed, at some point, all of Europe was successfully Christianized. The analysis exploits the timing and duration of Church exposure - so it is not a question of whether Christianity was adopted, but rather when it was adopted and for how long. This speaks against a fundamental incompatibility between deeply rooted characteristics of European ethnicities and Christianization. It is important to note, that lacking its own military power, historically the Western Church in Europe only established its administration once a Christian power took control over a new territory or secular rulers turned to Christianity. Military expansions of Christian rulers were most often driven by strategic considerations, e.g. in the case of the Carolingian empire to create buffer zones. This implies a top down Christianization which most often was accomplished by force. The timing of Christianization therefore seems to be primarily determined by geographic proximity to already Christianized areas and not by the Church strategically prioritizing certain areas.

\section{(2) The Churches' MFP vs. other Church-related or European factors}

Church exposure - bringing with it the MFP which is a set of human-made rules - is robustly associated with kinship intensity and human psychology. Our measure of Church exposure is highly correlated with Christianization and the formation of a Church administration. Our analysis is unable to empirically disentangle the effect of the Churches' MFP from other Church-related or unobserved factors that occurred around the same time. That is, the reduced form association between Church exposure and human psychology may not only go through the channel of kinship intensity. For example, while the MFP influenced kinship intensity, other religious practices of the Christian religion may have changed human psychology independently. While the analysis is not able to fully alleviate all endogeneity concerns, our analysis contains several features that are in line with the interpretation that the Churches' MFP was the decisive element.

(i) We report regressions on non-MFP sub-samples. In both the cross-country analysis (Section S3) and the children-of-immigrants analysis (Section S6), we report regressions that are based on a subsample that excludes all countries in which individuals' ancestors experienced more than four generations of Church exposure (this is similar to excluding all countries that have more than $10 \%$ European descent). These regressions of the psychological and behavioral dependent variables on kinship intensity allow us to check whether the relationship holds more universally - independently of the European experience. For example, these countries did not experience manorialism or European feudalism. Even though the sample size decreases considerably, the coefficients generally show the expected signs. In the children-of-immigrants analysis, the results are stronger. Both suggest that, independent of the European experience, an association between kinship intensity and human psychology exists. This is evidence against the idea that an unobserved European factor or some other Church feature may be driving our results. Rather, the association between kinship intensity and human psychology holds more generally.

(ii) We control for (present-day) religious adherence (Sections S3, S4, S6, S7), religiousness (Sections S3, S4, S6, S7) and the presence of monasteries before the year 1500 CE (Section S4). This 
mitigates the possibility that (i) differences in religious practices per se or (ii) technological, cultural or religious innovations and practices propagated by monasteries bias our estimates.

(iii) We focus on medieval variation in Church exposure. The regional analysis in Section $\mathbf{S} 4$ exploits medieval variation in Church exposure and its association with human psychology in regions of Europe, as well as kinship intensity in regions of Spain, Italy, and France. While these three countries exhibit variation in Church exposure before the $15^{\text {th }}$ century (due to Muslim, Lombard, and Carolingian conquests), all regions within these countries were subsequently firmly in the Catholic Church's sphere for many centuries (at the latest from the $15^{\text {th }}$ century onwards, but mostly before). Nonetheless, differences in contemporary kinship intensity still exist today. Regions with less exposure to the MFP up to the year $1500 \mathrm{CE}$ exhibit higher $20^{\text {th }}$ century cousin marriage rates. This (and controlling for religious adherence) suggests that if some other, Church-related factor drives the results, it would have had to co-occurred around the timing of the strongest enforcement and extent of the MFP, that is, in the time range between 506 and $1500 \mathrm{CE}$.

(iv) We exploit variation between the Eastern and the Western Churches' MFP. In the cross-country regressions (Section S3) we exploit variation in exposure to the Eastern vs. Western Churches. Both Churches are rooted in the same supernatural beliefs, rituals and scriptures. Yet, the extent and enforcement of the MFP was stronger in the Western Church. Consistent with our hypothesis, we document that Western Church exposure is indeed often more predictive of the expected psychological effects and quantitatively larger. While this evidence is consistent with the interpretation that the differing MFP between the Churches explain the differences, we are not able to rule out the possibility that Ottoman rule, which began in the $14^{\text {th }}$ century in most of the realm of the Eastern Church, confounds these results. However, Schulz (98) demonstrates that differences between areas in the realm of the Western and Eastern Church had already emerged before Ottoman rule. Areas of the Western Church saw comparably larger increases in urban and overall population, state formation, and formation of city-level inclusive institutions.

(v) We exploit variation in secular enforcement within the realm of the Western Church. In the regional analysis (Section S4), we demonstrate that residing in areas that belonged to the Carolingian Empire - a stalwart in the implementation and enforcement of the Church's MFP supported by secular rulers - is likewise associated with different kinship intensity and psychology today, even when controlling for country fixed effects. Yet, the overall European regional results do not hinge on the influence of the Carolingian Empire, since Western Church exposure is generally predictive of psychological outcomes even when controlling for the Carolingian Empire. Both (iv) and (v) indicate that marriage practices are decisive. 


\section{S3. Cross-country evidence}

Our analysis starts at the country level. We first investigate the relationship between kinship intensity and psychological outcomes as well as the reduced-form relation between Medieval Church exposure and psychological outcomes (Section S3.1). Section S3.2 sheds light on the relationship between the Churches' MFP and kinship intensity.

\section{S3.1. Kinship intensity, medieval Church exposure and psychology}

Here we demonstrate a robust association between our indicators of kinship intensity (the KII and log percent cousin marriages, both defined in Section S1) and a wide range of psychological and behavioral factors. In addition, we also report the reduced-form association between Church exposure (described in Section S2) and the same outcome variables.

We put special emphasis on behavioral measures, including both measures that were collected under ideal conditions in the laboratory and more ecologically relevant measures based on observational data. Experimental measures based on games played in a laboratory allow a high level of control and internal validity. The rules of the games are the same for all participants, and financial incentives are adjusted to minimize differences across societies. Importantly, in the experiments that produced data for our analyses, individuals were recruited to minimize the number of other participants they knew within the session and also interacted anonymously. The laboratory thus allows researchers to implement the same rules of the game, minimize reputational concerns and control social distance among participants. In a sense, participants interact with "outsiders", and the measure is thus very "clean". To gain insights into external validity, we turned to ecologically relevant observational measures that capture similar behaviors. Data on these measures are also available for larger samples, thus increasing the statistical power of the analyses.

In addition, we report results on widely used psychological attitudinal measures. Apart from their wide usage in the social sciences, attitudinal measures based on the World Value Survey (WVS) and European Social Survey (ESS) are advantageous because we can use these or similar measures for the analyses at the regional level (Sections S4 and S7) and the analysis of children of immigrants (Section S6). A regional analysis based on a more ecologically relevant variable is reported in Section S5, where we exploit variation in Italian provinces to show an association between cousin marriages and blood donations.

\section{Regression specification and covariates}

In the following, we analyze the association between our country-level explanatory variables (the countrylevel KII, log percent cousin marriage based on Bittles' cross-country data, ${ }^{37}$ and medieval Church exposure) and the psychological, behavioral, and attitudinal outcome variables. We report the raw correlations between the outcome and explanatory variables in bivariate figures and, for outcome variables with a reasonably large

\footnotetext{
37 We take the natural $\log$ for two reasons. One is technical: the percentage of cousin marriages is left-skewed. The other is a theoretical one. It is unlikely that the relationship between cousin marriages and the psychological outcomes is linear. It is more likely that the marginal impact decreases as cousin-marriages increase. That is, going from one to two percent cousin marriages probably has a bigger impact than going from 40 to 41 percent. Taking logs accounts for a decreasing marginal effect. Indeed, log percent cousin marriage often tends to be linearly associated with our outcome variables, as can be seen in Figures S3.1 to S3.7.
} 
sample size $(N \geq 40)$, the results from regression analyses. Across different regression specifications, we include various control variables that could otherwise bias our estimates of the relationship between kinship intensity and the outcome variables. We now describe these control variables (Section S9 provides further details on these variables).

Our Baseline geographic controls capture bio-geographic conditions and are included in most specifications. They include the following four variables:

- Ruggedness (based on Nunn and Puga (166)) and mean distance to waterways (based on Gallup, Sachs and Mellinger (167)). Both variables capture remoteness or accessibility. Remote areas may simultaneously affect distrust towards outsiders (for example, less exposure to outsiders or harsher living conditions may create stronger cohesion of the in-group) and also make it harder to find an unrelated marriage partner. Similarly, access to waterways can foster market integration and thereby increase cooperation with outsiders as work by Henrich et al. has shown (168-170).

- Caloric suitability of land for agriculture (based on Galor and Özak (171)). This variable measures the potential caloric output of non-irrigated, rain-fed land. Agriculture as a means of subsistence is associated with property rights. Defense of property, joint production, and the practice of keeping property within the family may have fostered the emergence of intensive kinship systems (and social stratification), leading to a psychology which more strongly favors the in-group. Thus, kin groups are likely an important channel through which means of subsistence affect in-group psychology. However, we cannot rule out the possibility that agriculture impacts kinship systems through other channels (e.g. harvesting technologies). Controlling for caloric suitability addresses this concern.

- Absolute latitude. Absolute latitude captures climatic conditions and is a common basic control in most cross-country regressions in the economics literature. Climatic conditions may have a direct impact on behavior and the formation of kinship intensity. To some absolute latitude, they also capture agricultural conditions as well as the presence of parasites. Fincher, Thornhill, Murray, and Schaller $(124,163,164)$ have brought forward the hypothesis that parasite stress, which tends to be higher in tropical climates, leads to an in-group bias in order to protect group members from infection. Tightly knit kin networks may thus be a consequence of parasite stress (172). Controlling for latitude mitigates these possibilities, though we directly control parasite stress below.

In addition to these baseline geographic controls, we estimated additional specifications with additional biogeographic control variables:

- Parasite stress (based on Fincher et al. (163), always included in Column 3 in Tables S3.1-S3.5) as mentioned above, could lead to an in-group bias. However, unlike the climatic control variables this indicator might be endogenous - societies with low kinship intensity and higher market integration might be better equipped to initiate large-scale cooperative projects and develop technology to reduce parasite stress $(173,174)$. As such, parasite stress might be at least partially the outcome of kinship intensity or the Church's MFP and therefore a "bad control" that biases the estimates (175). The results need to be interpreted with caution. 
- Percentage tropical climate (based on Nunn and Puga (166), always included in Column 3) is an additional measure for geographic conditions affecting both agricultural suitability as well as the potential for parasite stress. It measures the percentage of the land surface area of each country that has a tropical climate (based on the Koeppen-Geiger climate classification).

- A further agricultural control is irrigation potential (based on Bentzen et al. (176), always included in Column 4). A long-standing hypothesis suggests that irrigation impacts institutions and psychology (177, 178). Bentzen et al. (176) and Buggle (162) have shown that irrigation is associated with autocracy and collectivism, respectively. One channel for this association may be through kin-networks, as irrigation may lead to an increase in kinship intensity (easing investment in and protection of irrigated land) and therefore to more autocratic government or more collectivism. Controlling for suitability for irrigation addresses the concern that the estimates are biased by the effects of irrigation.

- Further agricultural covariates are caloric suitability for oats and caloric suitability for rye (based on Galor and Özak (171), always included in Column 5). We argue that one important source of variation in kinship intensity are the Church's MFP. Exposure to the MFP was confined to Europe in the Middle Ages. Several researchers have pointed out the importance of a medieval agricultural revolution in Europe $(76,179,180)$, which may introduce a confound. Mitterauer (76) describes oats and rye cultivation (and associated technological innovations) as a central factor for this medieval agricultural revolution. Controlling for their caloric suitability thus mitigates the possibility that these agricultural innovations bias the estimates.

- An additional variable related to agriculture is ancestor-adjusted years since the Neolithic Transformation (always included in Column 6). The onset of the Neolithic Transformation can be seen as a proxy for early bio-geographic conditions, since regions with conditions conducive for agriculture witnessed an earlier onset of the Neolithic Transformation (30). An earlier onset also implies that individuals were exposed to social structures that emerged due to agricultural subsistence for a longer period. However, the Neolithic Transformation was associated with a change in subsistence and the need to protect property, so its effects on today's psychological outcomes might again work through kin-networks. We use a variable coded by Putterman (181). This variable is ancestor adjusted by population movements that occurred after the year 1500 (using the migration matrix of Putterman and Weil (100)).

- Ancestor adjusted genetic heterogeneity (based on (182), always included in Column 6). In a series of papers, Galor and coauthors have emphasized its role for economic prosperity (182), autocracy (183), civil conflict (184), and cultural fragmentation (185). Arbatli et al. (184) demonstrate an association between genetic heterogeneity, trust and a preference for public goods provision. Apart from these biogeographic conditions, we also control for variables associated with religion:

- The fractions of adherents to each of Catholicism, Protestantism, Orthodox Christianity, other Christian denominations, Islam, Hinduism and Buddhism (from Barro and McCleary (186), always included in Column 7). Unsurprisingly, the fraction of Christians in a country is highly correlated with medieval Church exposure. Yet, there is also independent variation: a large fraction of people in Europe are nonreligious. In addition, Catholic missionary work after 1500 put less emphasis on the prohibition of consanguineous marriages (both through exemptions for the newly-Christianized and a less stringent enforcement of the kin-marriage ban), while Protestant missions usually did not ban consanguineous 
marriages (although, like Catholic missions, they forbid polygamous marriages). Due to the high correlations between the fraction of Christians and the medieval Church exposure, we expect the estimated coefficients in the regressions of the outcome variables on Church exposure to decrease. To some degree including these controls allows us to parse out the effect of the MFP, which experienced its strongest enforcement and extent during the medieval times, from other religion-related factors.

- The religiousness variable (always included in Column 8) is based on WVS data. Individuals rate how important religion is to them (0: not at all important, 3: very important). We aggregated to the country level by taking country means. Religiousness might itself be endogenous to intensive kinship systems. Once kin-networks dissolve and people become more individualistic and less constrained by traditions, and nation states with functioning welfare systems form, religion might lose its importance $(73,187)$. Due to this "bad control" problem the results have to be interpreted with caution (175). In addition to the results we report in this section, further evidence that both religious denomination and religiousness are not driving our results comes from the subsequent within-country analyses. In Sections S4, S6, S7, we control for religious denomination and religiousness at the individual level.

We also control for continent fixed effects (always included in Column 9). Given that the MFP originated in Europe (and the Australian and American continents are largely inhabited by people of European descent) there is not too much within continent variation at the country level. We therefore expect continent fixed effects to decrease the coefficients in the regressions of the outcomes on Church exposure.

While the Churches' MFP was decisive for the dissolution of intensive kinship systems, there also exists variation in kinship systems independent of the Churches' history. To address the concern that we capture an omitted European variable, in Columns 11 and 12 we excluded all countries where the inhabitants' ancestors experienced on average more than 120 years (i.e. 4 generations of 30 years) of either the Eastern or Western Churches' MFP. ${ }^{38}$ This amounts to excluding all European countries, Australia, New Zealand, South Africa, and most of the Americas (exceptions are Guatemala, Jamaica, Trinidad, and Tobago, Peru, and Haiti). Even though this decreases the sample size considerably (we report the regression output for all non-MFP subsamples even when $N \leq 40$ ), this allows us to investigate whether the associations with the KII and cousin marriage hold independently of the Churches' MFP or the European experience more generally. Finding evidence that this relationship holds independently of the European experience strengthens the argument that it is kinship intensity and not some other omitted European- or Church-related variable that explains the variation in the dependent variables. ${ }^{39}$

In the main regression specifications, we do not control for log GDP per capita or other contemporary factors like quality of infrastructure or institutions. Our main approach to address possible estimation bias due to contemporary factors like modern-day economic development is to use pre-industrial explanatory measures,

\footnotetext{
${ }^{38}$ The resulting sample is very similar to the one resulting from excluding all countries where more than $10 \%$ of the population has European ancestry.

${ }^{39}$ In the children of immigrants analysis (Section S6) we likewise exclude origin countries with a large fraction of European ancestry in some specifications, thus further strengthening the evidence that the association between kinship intensity and human psychology is robust. Moreover, in the following Section S4 we show that, even within Europe, similar associations between medieval Church exposure, kinship intensity and psychological outcomes exist, which makes an omitted European trait pertaining to the whole continent in this cross-country analysis less likely.
} 
like the KII and Church exposure. Because EA variables were coded with the aim of capturing characteristics before European contact or the Industrial Revolutions, the KII should be unaffected by contemporary factors; Church exposure likewise cannot be affected by contemporary factors. This rules out reverse causation or estimation bias due to omitted contemporary factors. Our within-country regional analyses (Sections S4 and S5) and our analyses of second-generation immigrants (Section S6), which control for country and even region fixed effects are further evidence that economic prosperity is unlikely to explain the cross-country findings. For completeness, in Table S3.9 below, we control for log GDP per capita, even though this is clearly a "bad control" (175), as we think GDP is most likely - at least partially - determined by kinship intensity.

As an additional robustness check, we report Conley standard errors (188) to account for spatial and cultural autocorrelation between the country-level observations (Table S3.8). We compute the Conley standard errors both using aerial distance between countries and genetic distance between the countries' populations. The latter accounts for population movements after the year 1500, which led to large geographic distances between some culturally and genetically related individuals (e.g., due to the migration of Europeans to the Americas).

\section{Analysis}

The following subsection describes all dependent variables and reports the results of the empirical analyses. We structured the psychological dependent variables along three domains: (1) individualism \& independence, (2) conformity \& obedience, and (3) impersonal prosociality. Impersonal prosociality is further divided into (3.a) impartiality and (3.b) impersonal cooperation \& trust. In addition, we report on (4) the value of strong nuclear family ties.

\section{(1) Individualism \& independence}

We analyze four measures of individualism \& independence: Hofstede's individualism (vs. collectivism), nopronoun drop, creativity, and analytic thinking.

Our first measure in the domain of individualism \& independence is Hofstede's (189) widely used cultural dimension of individualism (vs. collectivism). Hofstede characterizes individualism as "a preference for a loosely-knit social framework in which individuals are expected to take care of only themselves and their immediate families. Its opposite, collectivism, represents a preference for a tightly-knit framework in society in which individuals can expect their relatives or members of their in-group to look after them in exchange for unquestioning loyalty. A society's position on this dimension is reflected in whether people's self-image is defined in terms of "I" or "we."” This measure is therefore closely related to intensive kinship systems and their focus on the in-group. The indicator is based on 30 questions and the data was mainly collected from IBM employees around the world. Altogether, we have data on 102 countries.

Our second measure of individualism \& independence is no-pronoun drop. Kashima and Kashima (190) noticed that countries with languages in which the first-person pronoun in a sentence can be dropped tend to be less individualistic. In English or German, for example, it is not grammatically correct to drop the subject of a sentence, while many other languages allow it. The subject of the sentence is sometimes implied by the 
verb conjugation, for instance, in Spanish. Kashima and Kashima argue that first-person pronoun dropping can be understood as a way for the speaker to de-emphasize their own significance. Similarly, cultures with languages that do not drop the pronoun tend to emphasize the significance of the individual. Interestingly, just as in the case of kin-terms, ${ }^{40}$ several European languages like English, French, German, Dutch, and Northern Italian dialects became no-pronoun drop languages after exposure to the Church's MFP (191). We use data provided by Tabellini (192), giving us 71 country-level observations. No-pronoun drop takes on a value of 0 if the first person singular pronoun can be dropped and 1 if it cannot. Intermittent values reflect multiple languages with different rules spoken within a country.

Our third measure in the domain of individualism \& independence is creativity. This measure is likewise based on a Schwarz human values question asked in the WVS. People rate on a six-point scale how much they believe the person described in the following sentence is like them: "It is important to this person to think up new ideas and be creative; to do things one's own way." Since we do not want to capture cultural differences in closeness perceptions, we again subtracted the mean answers a respondent gave to all human value questions from the respondent's answer to the creativity question following Schwarz's recommendation (193). We aggregated answers to the country level by taking the countries' means and standardized the variable at the country level. Below in Section S7, we also use this measure in a within-country analysis, and this measure also is one item in the ESS-based individualism-independence measure we use in the European regional analysis (Section S4) and the second-generation immigrants analysis (Section 6).

Analytic thinking is our fourth measure. It is based on the triad task (194) as implemented and kindly provided to us by Thomas Talhelm $(122,195)$. The triad task shows three items, such as train, bus, and tracks. Two of the items belong to the same abstract category (train and bus belong to the category "vehicles"), and two share a functional relationship (trains run on tracks). Respondents are asked which two items belong together. Although this measure of analytic thinking is conceptually distinct from the other measures in the domain of individualism \& independence, it is believed to reflect the style of thinking in more individualistic environments $(122,196,197)$. People from WEIRD societies more often choose abstract (analytic) pairings, whereas East Asians and people from other collectivistic cultures choose more relational (holistic) pairings $(122,151,194)$. Reported are the percentage of analytic choices individuals made. Based on work in psychology (198), we hypothesize that high kinship intensity, where individuals are embedded in a network of obligations and specified roles, fosters holistic thinking .

The top row of Figure S3.1 shows the association between kinship systems and measures in the domain of individualism \& independence. Higher kinship intensity is associated with lower individualism (or more collectivism), more pronoun dropping and less creativity.

\footnotetext{
${ }^{40}$ Kin-terms in Europe changed chronologically following the introduction of the MFP in a way that is consistent with an increased emphasis on the nuclear family and with a decreased preference for cousin marriage (see Section 1 for details).
} 

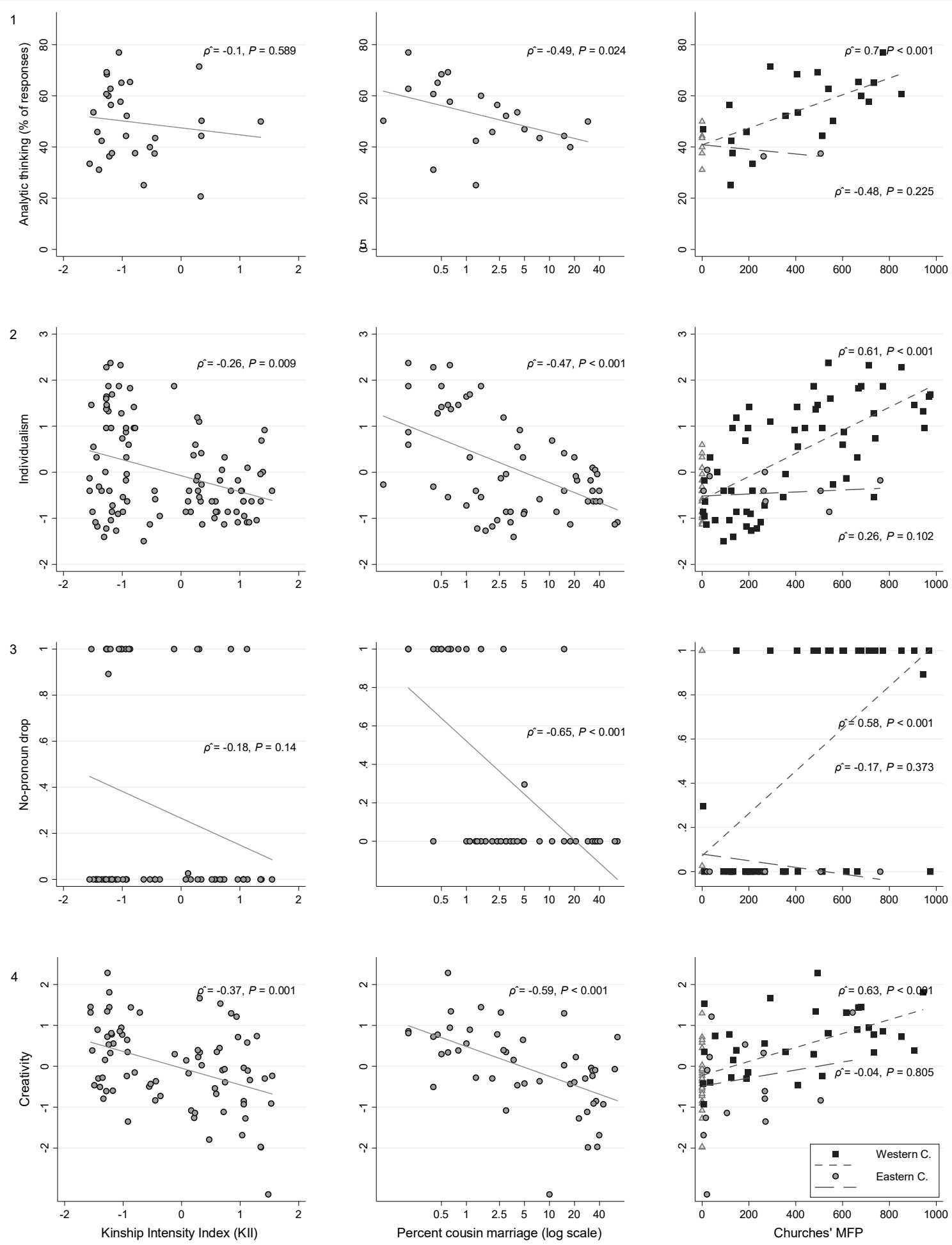

Figure S3.1: Analytic thinking (top row), individualism (second row), no-pronoun drop (third row), and creativity (bottom row) in relation to the Kinship Intensity Index (first column), percent cousin marriages (second column), and Church exposure (third column). Linear best-fit lines are displayed; in the third column, countries primarily impacted by the Western Church's MFP are identified with a black square (short-dashed best-fit lines), countries primarily impacted by the Eastern Church's MFP are identified by a grey circle (long-dashed best-fit lines), while triangles denote no Church exposure. Reported are Spearman's $\rho$ and associated significance levels (two-sided). 


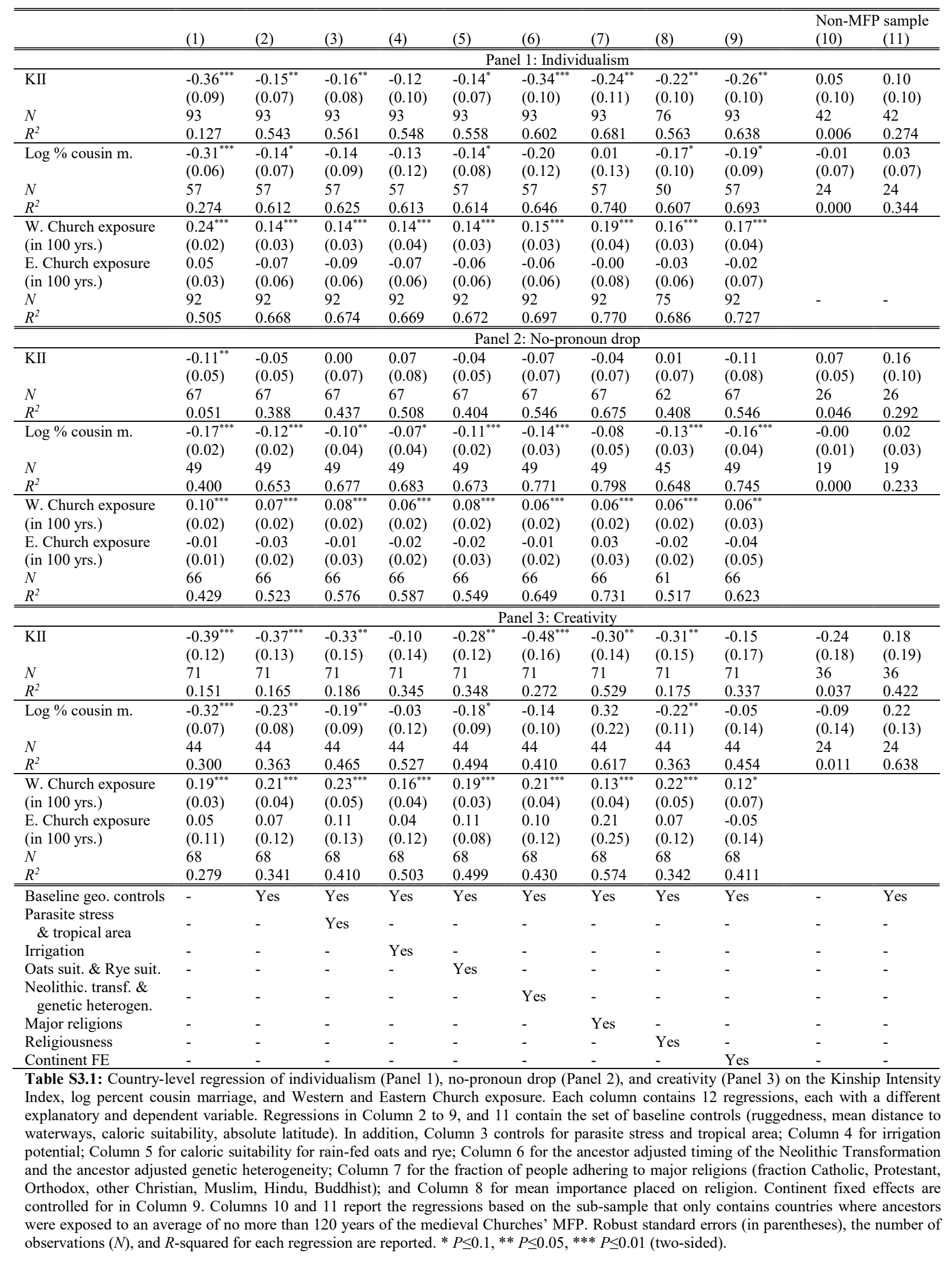


The results of the regression analysis in Table S3.1 corroborate these findings. A one standard deviation increase in the KII decreases individualism by 0.36 standard deviation, while a doubling of cousin marriages decreases it by $0.21(\approx-0.31 \cdot \ln (2))$ standard deviations. Similar effects sizes are found between our two measures of kinship intensity and creativity. The associations of these three dependent variables with kinship intensity are generally robust to the inclusion of covariates. Out of the 54 estimated coefficients of interest 51 have the hypothesized sign. Controlling for irrigation potential reduces the significance levels, but here too almost all coefficients have the hypothesized sign. Moreover, a plausible mechanism is that irrigation fosters kinship intensity which in turn impacts human psychology. Irrigation potential and kinship intensity are therefore related which increases uncertainty in the estimates. Consistent with the hypothesis that the Western Church's MFP had stronger effects than the Eastern Church's MFP, the regression results reveal robust reduced-form associations between Western Church exposure and individualism, pronoun drop, and creativity. Across the board they are robust to the inclusion of the covariates. Similar associations for Eastern Church exposure are not found. In the non-European ancestry sub-sample (non-MFP) and in contrast to the regressions that focus on the dimension of obedience \& conformity, the coefficients are not significant.

\section{(2) Conformity \& obedience}

We analyze five measures that capture conformity \& obedience: tightness, Asch conformity, obedience, tradition, and proper behavior.

Our first measure in the domain of conformity \& obedience, tightness, was developed by Gelfand et al. (133). Tight cultures are defined as having strong norms and low tolerance of deviant behavior, while loose cultures have weak norms and a high tolerance of deviant behavior. They developed a measure to capture the degree to which social norms are pervasive, clearly defined, and reliably imposed in a country. On a six item Likert scale (ranging from strongly agree to strongly disagree), respondents rated statements such as: "There are many social norms that people are supposed to abide by in this country"; "In this country, if someone acts in an inappropriate way, others will strongly disapprove"; and "People in this country almost always comply with social norms"). Altogether, respondents rated six statements. Data is available for 6,823 respondents across 33 countries. This measure is related to obedience; but, on the other hand, it is indicative of the presence of specific situational norms. In societies with higher kinship intensity this may be an important way to organize interactions between different kin groups. Specific norms might decrease the possibility of misunderstandings and the eruption of conflicts.

Our second measure in the domain of conformity \& obedience, Asch conformity, is an experimental measure based on the seminal work by Solomon Asch (199-201). Ash was interested in knowing the extent to which people would follow the answers picked by the majority, when those answers are obviously wrong. In his experiment, subjects are asked to judge which line (out of a set of three) is of the same length as a comparison line. Unbeknownst to the subjects, a majority of the other participants in the room are confederates, all of whom point to the same wrong answer. Subsequently, the subjects make a judgement about the line. Our outcome variable of interest is the percentage of subjects who follow the majority and pick the objectively wrong answer. The data is taken from a meta-study conducted by Bond and Smith (120), which is based on 133 studies in 17 countries. 
We complement this laboratory measure with three survey measures which are conceptually related to conformity and for which data are available for larger samples of countries. The first survey measure is obedience. In the WVS, respondents are asked to choose up to five qualities they consider important to instill in children. Based on responses to this question, we coded the percentage of people in a country who choose "obedience" as an important child quality (see also Tabellini (202) and Alesina and Giuliano (134, 136), who use this indicator). In total we have data on 112 countries.

The other two additional measures, tradition and proper behavior, are likewise taken from the WVS. They are based on two (out of several) human value questions that were developed by Schwarz (193). In each of the human value questions, respondents are asked to state how much a person with particular values is like themselves. Tradition is based on people's rating of the statement: "Tradition is important to this person; to follow the customs handed down by one's religion or family", while proper behavior is based on the statement "It is important to this person to always behave properly; to avoid doing anything people would say is wrong". For each statement, respondents could answer on a six-point scale ranging from "very much like me" to "not at all like me". To mitigate the possibility that the measures capture cultural differences in "closeness perceptions" arising from the way the question is posed, we calculated each respondent's "closeness perception" by taking the mean of his/her answers across all of the human value items in the WVS. This captures how strongly an individual perceives others to be overall like himself/herself. We then subtracted an individual's closeness perception from her/his answers to both the tradition and proper behavior questions. This follows Schwarz's recommendation to address confounding the human value items with cross-societal differences in closeness perceptions. ${ }^{41} \mathrm{We}$ subsequently aggregated the measures to the country level and standardized them. Based on Waves 5 and 6 of the WVS, we obtained data on 78 countries.

We hypothesize that kinship intensity fosters conformity \& obedience. Consistent with this hypothesis, Figure S3.2 shows a significantly negative relationship between kinship intensity and four of our five measures in the domain of conformity \& obedience. Further, the longer medieval Church exposure, the lower the measures for conformity \& obedience. Only for the measure proper behavior do we not find an association.

\footnotetext{
${ }^{41} \mathrm{We}$ included only individuals who answered all human value questions. The human value questions were asked in Waves 5 and 6 of the WVS. There is some variation in the questions asked by wave and country (not all 11 questions were asked in each country and in each wave). However, individuals from the countries included were always asked at least 10 of the questions.
} 

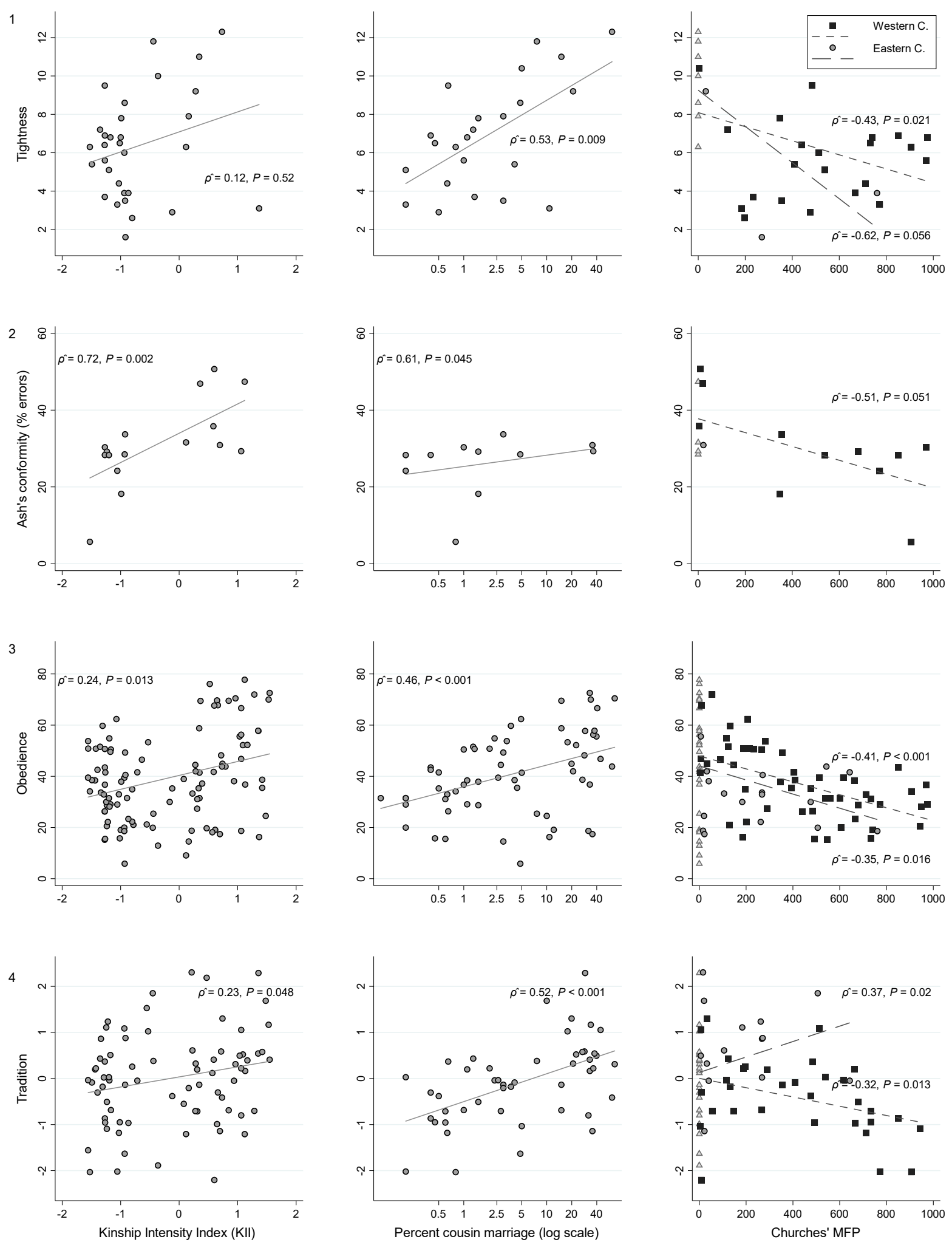

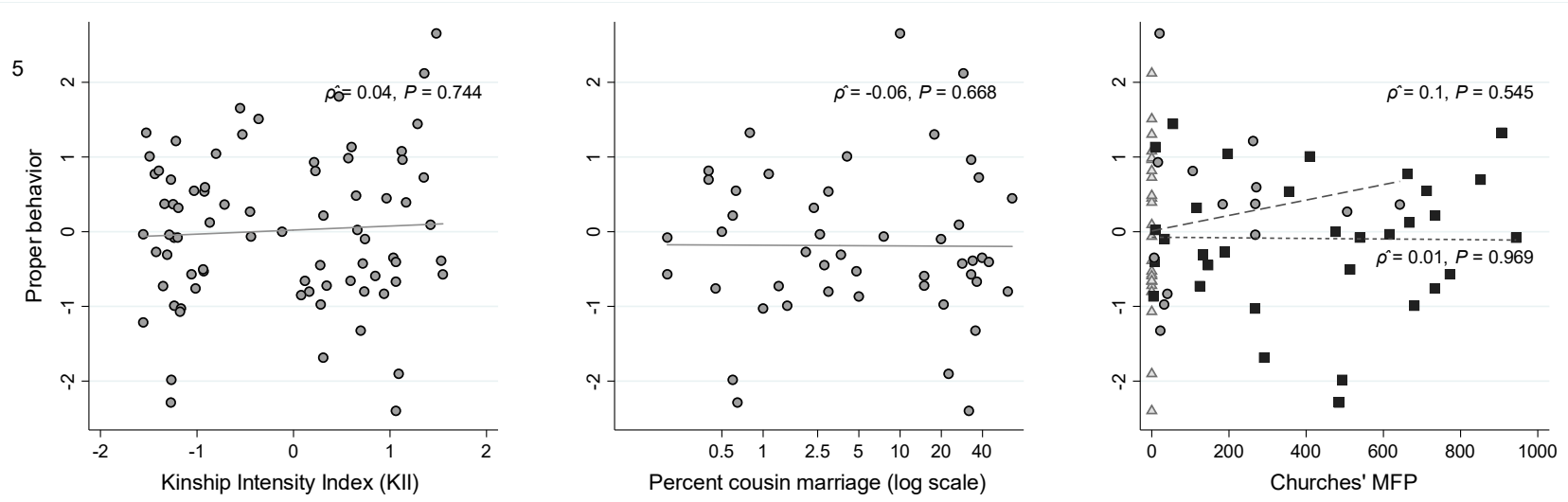

Figure S3.2: Tightness (top row), Asch's conformity measure (second row), obedience (third row), tradition (fourth row) and proper behavior (fifth row) in relation to the Kinship Intensity Index (first column), percent of cousin marriages (second column), and Church exposure (third column). Linear best-fit lines are displayed; in the third column, countries primarily impacted by the Western Church's MFP are identified with a black square (short-dashed best-fit lines), countries primarily impacted by the Eastern Church's MFP are identified by a grey circle (long-dashed best-fit lines), while triangles denote no Church exposure. Reported are Spearman's $\rho$ and associated significance levels (two-sided).

Table S3.2 reports the regression results for obedience, tradition, and proper behavior as dependent variables. Because their samples are small $(n<40)$, we do not report the results of regressions with tightness $(\mathrm{N}=33)$ or Ash conformity $(\mathrm{N}=17)$ as the dependent variables. The results show that kinship intensity is positively associated with obedience and tradition. A one standard deviation increase in KII is associated with about a 7percentage point increase in obedience and a 0.21 standard deviation increase in tradition, while doubling cousin marriage increases obedience by about $3(\approx 4.05 \cdot \ln (2))$ percentage points and tradition by $0.19(\approx$ $0.28 \cdot \ln (2))$ standard deviations. The association between the KII and obedience is more robust compared to log percent cousin marriage and obedience. In the case of tradition, log percent cousin marriage is more robustly associated. Except when controlling for the fraction of adherence to major religions, all coefficients have the expected sign. Given the strong association between adherence to major religions today and medieval Church exposure, this is not surprising. The subsequent individual-level analyses (Section 4, 6, 7) will demonstrate that this relationship unlikely to be due to religious adherence today. Interestingly, the results are larger in magnitude for the subsample of countries that had no more than 120 years of exposure to either Churches and, in the case of obedience, are robust to the inclusion of the baseline controls. Western Church exposure is robustly negatively related to tradition. This underscores the importance of intensive kinship independent of the European experience.

As already shown in Figure S3.2, there is no significant relationship between kinship intensity or Church exposure and proper behavior; the results of the regression analyses for proper behavior are given in the last panel of Table S3.2. 


\begin{tabular}{|c|c|c|c|c|c|c|c|c|c|c|c|}
\hline & $(1)$ & $(2)$ & $(3)$ & (4) & $(5)$ & $(6)$ & $(7)$ & $(8)$ & $(9)$ & $\begin{array}{l}\begin{array}{l}\text { Non-MF } \\
(10)\end{array} \\
\end{array}$ & $\begin{array}{l}\text { P sample } \\
\text { (11) }\end{array}$ \\
\hline & \multicolumn{11}{|c|}{ Panel 1: Obedience (percentage) } \\
\hline KII & $\begin{array}{l}6.76^{* * *} \\
(1.71)\end{array}$ & $\begin{array}{l}2.90^{* *} \\
(1.44)\end{array}$ & $\begin{array}{l}2.82^{*} \\
(1.69)\end{array}$ & $\begin{array}{l}2.85^{*} \\
(1.69)\end{array}$ & $\begin{array}{l}3.51^{* *} \\
(1.62)\end{array}$ & $\begin{array}{l}1.08 \\
(1.92)\end{array}$ & $\begin{array}{l}5.74^{* * *} \\
(1.99)\end{array}$ & $\begin{array}{l}1.90 \\
(1.40)\end{array}$ & $\begin{array}{l}5.70^{* * *} \\
(1.72)\end{array}$ & $\begin{array}{l}8.82^{* *} \\
(3.68)\end{array}$ & $\begin{array}{l}10.81^{* * *} \\
(2.97)\end{array}$ \\
\hline$N$ & 96 & 96 & 96 & 96 & 96 & 96 & 96 & 95 & 96 & 41 & 41 \\
\hline$R^{2}$ & 0.152 & 0.554 & 0.571 & 0.554 & 0.574 & 0.587 & 0.670 & 0.607 & 0.657 & 0.127 & 0.626 \\
\hline Log $\%$ cousin $m$. & $\begin{array}{l}4.05^{* * *} \\
(0.90)\end{array}$ & $\begin{array}{l}1.63 \\
(1.16)\end{array}$ & $\begin{array}{l}0.34 \\
(1.43)\end{array}$ & $\begin{array}{l}0.74 \\
(1.58)\end{array}$ & $\begin{array}{l}1.57 \\
(1.27)\end{array}$ & $\begin{array}{l}0.79 \\
(1.83)\end{array}$ & $\begin{array}{l}5.10^{* *} \\
(2.13)\end{array}$ & $\begin{array}{l}-0.02 \\
(1.20)\end{array}$ & $\begin{array}{l}4.63^{* * *} \\
(1.66)\end{array}$ & $\begin{array}{l}6.57^{*} \\
(3.64)\end{array}$ & $\begin{array}{l}6.06^{* *} \\
(2.88)\end{array}$ \\
\hline$N$ & 56 & 56 & 56 & 56 & 56 & 56 & 56 & 55 & 56 & 26 & 26 \\
\hline$R^{2}$ & 0.213 & 0.442 & 0.534 & 0.458 & 0.444 & 0.461 & 0.680 & 0.548 & 0.574 & 0.162 & 0.504 \\
\hline W. Church exposure & $\begin{array}{l}-2.49^{* * *} \\
(0.48)\end{array}$ & 0.10 & 0.65 & $\begin{array}{l}0.22 \\
(058)\end{array}$ & 0.04 & $\begin{array}{l}0.21 \\
(0.51)\end{array}$ & $\begin{array}{l}-0.68 \\
(0.60)\end{array}$ & $\begin{array}{l}0.77 \\
(0.48)\end{array}$ & $\begin{array}{l}-0.52 \\
(0.70)\end{array}$ & & \\
\hline $\begin{array}{l}\text { (in } 100 \text { yrs.) } \\
\text { E Church exposure }\end{array}$ & $\begin{array}{l}(0.48) \\
-3.67^{* * *}\end{array}$ & $\begin{array}{l}(0.55) \\
0.55\end{array}$ & $(0.57)$ & $\begin{array}{l}(0.58) \\
0.56\end{array}$ & $\begin{array}{l}(0.57) \\
0.71\end{array}$ & $\begin{array}{l}(0.51) \\
0.38\end{array}$ & $\begin{array}{l}(0.60) \\
2.45\end{array}$ & $\begin{array}{l}(0.48) \\
0.44\end{array}$ & $\begin{array}{l}(0.70) \\
-0.71\end{array}$ & & \\
\hline $\begin{array}{l}\text { E. Church exposure } \\
\text { (in } 100 \text { yrs.) }\end{array}$ & $\begin{array}{l}-3.67 \\
(0.95)\end{array}$ & $\begin{array}{l}0.55 \\
(1.14)\end{array}$ & $\begin{array}{l}1.21 \\
(1.22)\end{array}$ & $\begin{array}{l}0.56 \\
(1.17)\end{array}$ & $\begin{array}{l}0.71 \\
(1.16)\end{array}$ & $\begin{array}{l}0.38 \\
(1.10)\end{array}$ & $\begin{array}{l}2.45 \\
(1.67)\end{array}$ & $\begin{array}{l}0.44 \\
(1.07)\end{array}$ & $\begin{array}{l}-0.71 \\
(1.27)\end{array}$ & & \\
\hline$N$ & 92 & 92 & 92 & 92 & 92 & 92 & 92 & 91 & 92 & & \\
\hline \multirow[t]{2}{*}{$R^{2}$} & 0.223 & 0.545 & 0.586 & 0.550 & 0.558 & 0.620 & 0.653 & 0.627 & 0.635 & & \\
\hline & \multicolumn{11}{|c|}{ Panel 2: Tradition (z-scores) } \\
\hline KII & $\begin{array}{l}0.21^{* *} \\
(0.11)\end{array}$ & $\begin{array}{l}0.23^{* *} \\
(0.11)\end{array}$ & $\begin{array}{l}0.23^{*} \\
(0.13)\end{array}$ & $\begin{array}{l}0.04 \\
(0.13)\end{array}$ & $\begin{array}{l}0.16 \\
(0.11)\end{array}$ & $\begin{array}{l}0.20 \\
(0.16)\end{array}$ & $\begin{array}{l}-0.00 \\
(0.17)\end{array}$ & $\begin{array}{l}0.02 \\
(0.13)\end{array}$ & $\begin{array}{l}0.21 \\
(0.19)\end{array}$ & $\begin{array}{l}0.31 \\
(0.19)\end{array}$ & $\begin{array}{l}-0.10 \\
(0.16)\end{array}$ \\
\hline$N$ & 71 & 71 & 71 & 71 & 71 & 71 & 71 & 71 & 71 & 36 & 36 \\
\hline$R^{2}$ & 0.047 & 0.065 & 0.068 & 0.163 & 0.179 & 0.119 & 0.487 & 0.203 & 0.133 & 0.062 & 0.340 \\
\hline Log $\%$ cousin $m$. & $\begin{array}{l}0.28^{* * *} \\
(0.07)\end{array}$ & $\begin{array}{l}0.18^{* *} \\
(0.07)\end{array}$ & $\begin{array}{l}0.17^{*} \\
(0.09)\end{array}$ & $\begin{array}{l}0.10 \\
(0.09)\end{array}$ & $\begin{array}{l}0.21^{* * * *} \\
(0.07)\end{array}$ & $\begin{array}{l}0.16 \\
(0.12)\end{array}$ & $\begin{array}{l}-0.13 \\
(0.17)\end{array}$ & $\begin{array}{l}0.08 \\
(0.07)\end{array}$ & $\begin{array}{l}0.16 \\
(0.12)\end{array}$ & $\begin{array}{l}0.21^{*} \\
(0.10)\end{array}$ & $\begin{array}{l}0.03 \\
(0.09)\end{array}$ \\
\hline$N$ & 44 & 44 & 44 & 44 & 44 & 44 & 44 & 44 & 44 & 24 & 24 \\
\hline$R^{2}$ & 0.310 & 0.420 & 0.423 & 0.455 & 0.461 & 0.422 & 0.545 & 0.472 & 0.463 & 0.081 & 0.449 \\
\hline $\begin{array}{l}\text { W. Church exposure } \\
\text { (in } 100 \text { vrs. }\end{array}$ & $\begin{array}{l}-0.13^{* * *} \\
(0.03)\end{array}$ & $\begin{array}{l}-0.16^{* * *} \\
(0.05)\end{array}$ & $\begin{array}{l}-0.17^{* * *} \\
(0.06)\end{array}$ & $\begin{array}{l}-0.13^{* *} \\
(0.05)\end{array}$ & $\begin{array}{l}-0.13^{* * *} \\
(0.05)\end{array}$ & $\begin{array}{l}-0.15^{* * *} \\
(0.05)\end{array}$ & $\begin{array}{l}-0.09 \\
(0.06)\end{array}$ & $\begin{array}{l}-0.12^{* *} \\
(0.05)\end{array}$ & $-0.16^{* *}$ & & \\
\hline E. Church exposure & 0.16 & 0.15 & 0.13 & 0.17 & 0.17 & 0.13 & -0.24 & 0.16 & 0.16 & & \\
\hline (in $100 \mathrm{yrs}$.) & $(0.11)$ & $(0.14)$ & $(0.15)$ & $(0.14)$ & $(0.11)$ & $(0.14)$ & $(0.20)$ & $(0.15)$ & $(0.14)$ & & \\
\hline$N$ & 68 & 68 & 68 & 68 & 68 & 68 & 68 & 68 & 68 & & \\
\hline \multirow[t]{2}{*}{$R^{2}$} & 0.221 & 0.312 & 0.324 & 0.378 & 0.375 & 0.352 & 0.522 & 0.347 & 0.333 & & \\
\hline & \multicolumn{11}{|c|}{ Panel 3: Proper behavior (z-scores) } \\
\hline KII & $\begin{array}{l}0.07 \\
(0.12)\end{array}$ & $\begin{array}{l}0.14 \\
(0.12)\end{array}$ & $\begin{array}{l}0.16 \\
(0.12)\end{array}$ & $\begin{array}{l}0.00 \\
(0.13)\end{array}$ & $\begin{array}{l}0.11 \\
(0.12)\end{array}$ & $\begin{array}{l}0.11 \\
(0.18)\end{array}$ & $\begin{array}{l}0.17 \\
(0.19)\end{array}$ & $\begin{array}{l}0.08 \\
(0.13)\end{array}$ & $\begin{array}{l}0.21 \\
(0.18)\end{array}$ & $\begin{array}{l}0.08 \\
(0.21)\end{array}$ & $\begin{array}{l}0.10 \\
(0.22)\end{array}$ \\
\hline$N$ & 71 & 71 & 71 & 71 & 71 & 71 & 71 & 71 & 71 & 36 & 36 \\
\hline$R^{2}$ & 0.006 & 0.146 & 0.212 & 0.199 & 0.225 & 0.147 & 0.294 & 0.158 & 0.163 & 0.004 & 0.132 \\
\hline Log $\%$ cousin $m$. & $\begin{array}{l}0.03 \\
(0.08)\end{array}$ & $\begin{array}{l}0.01 \\
(0.08)\end{array}$ & $\begin{array}{l}0.02 \\
(0.08)\end{array}$ & $\begin{array}{l}-0.12 \\
(0.08)\end{array}$ & $\begin{array}{l}-0.04 \\
(0.08)\end{array}$ & $\begin{array}{l}-0.08 \\
(0.09)\end{array}$ & $\begin{array}{l}-0.33 \\
(0.23)\end{array}$ & $\begin{array}{l}-0.02 \\
(0.09)\end{array}$ & $\begin{array}{l}-0.00 \\
(0.16)\end{array}$ & $\begin{array}{l}-0.13 \\
(0.11)\end{array}$ & $\begin{array}{l}-0.21 \\
(0.15)\end{array}$ \\
\hline$N$ & 44 & 44 & 44 & 44 & 44 & 44 & 44 & 44 & 44 & 24 & 24 \\
\hline$R^{2}$ & 0.003 & 0.155 & 0.239 & 0.241 & 0.228 & 0.171 & 0.362 & 0.160 & 0.190 & 0.023 & 0.210 \\
\hline $\begin{array}{l}\text { W. Church exposure } \\
\text { (in } 100 \text { yrs.) }\end{array}$ & $\begin{array}{l}-0.02 \\
(0.04)\end{array}$ & $\begin{array}{l}0.03 \\
(0.04)\end{array}$ & $\begin{array}{l}0.00 \\
(0.05)\end{array}$ & $\begin{array}{l}0.06 \\
(0.04)\end{array}$ & $\begin{array}{l}0.02 \\
(0.05)\end{array}$ & $\begin{array}{l}0.03 \\
(0.04)\end{array}$ & $\begin{array}{l}0.10^{*} \\
(0.06)\end{array}$ & $\begin{array}{l}0.04 \\
(0.05)\end{array}$ & $\begin{array}{l}0.05 \\
(0.08)\end{array}$ & & \\
\hline E. Church exposure & $0.11^{*}$ & $0.14^{* *}$ & 0.10 & $0.16^{* *}$ & 0.10 & $0.13^{*}$ & -0.20 & $0.14^{* *}$ & 0.17 & & \\
\hline (in $100 \mathrm{yrs}$.) & $(0.05)$ & $(0.07)$ & $(0.08)$ & $(0.07)$ & $(0.07)$ & $(0.07)$ & $(0.22)$ & $(0.07)$ & $(0.15)$ & & \\
\hline$N$ & 68 & 68 & 68 & 68 & 68 & 68 & 68 & 68 & 68 & & \\
\hline$R^{2}$ & 0.025 & 0.185 & 0.235 & 0.259 & 0.253 & 0.197 & 0.325 & 0.195 & 0.203 & & \\
\hline Baseline geo. controls & - & Yes & Yes & Yes & Yes & Yes & Yes & Yes & Yes & - & Yes \\
\hline $\begin{array}{l}\text { Parasite stress } \\
\& \text { tropical area }\end{array}$ & - & - & Yes & - & - & - & - & - & - & - & - \\
\hline Irrigation & - & - & - & Yes & - & - & - & - & - & - & - \\
\hline Oats suit. \& Rye suit. & & & & & Yes & & & & & - & - \\
\hline $\begin{array}{l}\text { Neolithic. transf. \& } \\
\text { genetic heterogen. }\end{array}$ & - & - & - & - & - & Yes & - & - & - & - & - \\
\hline Major religions & - & - & - & - & - & - & Yes & - & - & - & - \\
\hline Religiousness & - & - & - & - & - & - & - & Yes & - & - & - \\
\hline Continent FE & - & - & - & - & - & - & - & - & Yes & - & - \\
\hline \multicolumn{12}{|c|}{$\begin{array}{l}\text { Table S3.2: Country-level regression of obedience (Panel 1), tradition (Panel 2), and proper behavior (Panel 3) on the Kinship Intensity Index, } \\
\text { log percent cousin marriage, and Eastern and Western Church exposure. Each column contains } 12 \text { regressions, each with a different explanatory } \\
\text { and dependent variables. Regressions in Columns } 2 \text { to } 9 \text {, and } 11 \text { contain the set of baseline controls (ruggedness, mean distance to waterways, } \\
\text { caloric suitability, absolute latitude). In addition, Column } 3 \text { controls for parasite stress and tropical area; Column } 4 \text { for irrigation potential; } \\
\text { Column } 5 \text { for caloric suitability for rain-fed oats and rye; Column } 6 \text { for the ancestor adjusted timing of the Neolithic Transformation and the } \\
\text { ancestor adjusted genetic heterogeneity; Column } 7 \text { for the fraction of people adhering to major religions (fraction Catholic, Protestant, } \\
\text { Orthodox, other Christian, Muslim, Hindu, Buddhist); and Column } 8 \text { for mean importance placed on religion. Continent fixed effects are } \\
\text { controlled for in Column } 9 \text {; Columns } 10 \text { and } 11 \text { report the regressions based on the sub-sample that only contains countries where ancestors } \\
\text { were exposed to an average of no more than } 120 \text { years of the medieval Churches' MFP. Robust standard errors (in parentheses), the number of } \\
\text { observations }(N) \text {, and } R \text {-squared for each regression are reported. } * P \leq 0.1, * * P \leq 0.05 \text {, *** } P \leq 0.01 \text { (two-sided). }\end{array}$} \\
\hline
\end{tabular}




\section{(3) Impersonal prosociality}

\section{Impartiality}

We analyze four measures of impartiality: honesty, unpaid parking tickets, nepotism, and particularism.

Our first measure is an experimental measure of impersonal honesty based on Gaechter and Schulz (128). They conducted a behavioral die-under-the-cup experiment (following Fischbacher and Foellmi-Heusi (203)) with student participants in 23 countries. The countries were selected based on macroeconomic indicators to be representative of the range of countries around the world. While student participants are not representative of a country's population, they are somewhat comparable between countries because they tend to be drawn from similar upper middle class socio-economic backgrounds. In an experimental setting, each participant was asked to throw a die in private and to report the number rolled. The payout depended on the number reported, with payments linearly increasing in the reported numbers (a roll of "1" corresponding to 1 experimental currency unit (ECU), a roll of " 2 " to 2 ECU, etc... - except a reported roll of " 6 " lead to no payment). In an environment where reputational concerns are minimized, this creates an incentive to lie and report high-paying numbers. Our dependent variable, percent high claims, is defined as the percentage of high paying numbers (the numbers 3,4 , and 5) reported in each subject pool. In a fully honest subject pool, highpaying numbers should occur about $50 \%$ of the time, while in a fully dishonest and selfish subject pool, high paying numbers should occur $100 \%$ of the time. Percent high claims is thus indicative of the prevalence of dishonesty in the subject pool. The measure allows for a high degree of experimental control, as reputational concerns are minimized and financial incentives are adjusted to reflect local purchasing power. Since the cost of lying is incurred by an out-group member (the experimenter), we hypothesize that intensive kinship systems lead to lower levels of impersonal honesty.

We also analyze the dependent variable unpaid parking tickets per diplomat, an ecologically relevant measure for which data are available for a larger sample of countries (Fisman and Miguel (204)). The variable is defined as the number of unpaid parking tickets accrued among United Nations diplomats in New York City. Diplomatic immunity provided consular officials and their families with protection from prosecution. Thus, there is a financial motive to violate the rule and not to pay parking tickets. Fisman and Miguel (204) show a strong association between log unpaid parking ticket per diplomat and corruption levels in the diplomats' home countries. The total period of coverage is November 24, 1997, to October 2002 when the State Department started penalizing outstanding unpaid violations

Our third measure, nepotism, is taken from Van de Vliert (160) and measures the degree to which senior management positions in companies are chosen based on superior qualifications vs. kin relationships. It is based on a multi-country survey of business executives conducted by researchers from the World Economic Forum. Data were collected from nationally representative samples of firms. We hypothesize that in societies with higher kinship intensity, more senior management positions will be filled by kin.

Our fourth measure, particularism, captures the preference for helping kith and kin over following universally applicable and impartial rules of fairness. It is based on publications by Hampden-Turner and Trompenaars (205). They describe the responses of multinational corporate managers to the passenger's dilemma. In the passenger's dilemma, managers answered questions with regard to the following scenario: 
Consider for a moment this dilemma: You are a passenger in a car driven by a close friend, and your close friend's car hits a pedestrian. You know that your friend was going at least thirty-five miles an hour in an area where the maximum speed was twenty miles an hour. There are no witnesses. Your friend's lawyer says that if you testify under oath that the speed was only twenty miles an hour, then you would save your friend from any serious consequences. What would you do? Would you lie to protect your friend? What right does your friend have to expect your help? On the other hand, what are your obligations to society to uphold the law?

One must therefore make a choice between either lying under oath and helping a friend or telling the truth and compromising the friend. The variable reported by Hampden-Turner and Trompenaars is the percentage of a country's respondents who stated either (i) that the friend has a definite right to expect the respondent to lie for him or (ii) that the respondent would lie under oath. As data was updated in successive publications, we took the most recent data available for each country. Our theory predicts that stronger kinship intensity or less Church exposure will be associated with greater particularism.

Figure S3.3 illustrates the association between kinship intensity and Church exposure on the one hand, and our two measures of impersonal honesty and rule breaking on the other hand. The highly significant association is apparent.

Table S3.3 reports the regression results. The specifications are the same as those in Table S3.1, but with different dependent variables in each panel: log unpaid parking tickets and nepotism. (We do not report the results of regressions with the dishonesty dice game (percent high claims) and particularism as the dependent variables because the sample sizes are too low.) The results consistently reveal a positive association between kinship intensity and unpaid parking tickets (Panel 1). Column 1 suggests that a one-standard-deviation increase in the KII increases the number of unpaid parking tickets by about $82 \%(82 \% \approx \exp (0.60)-1)$, and a doubling of cousin marriages increases it by about $30 \%$. The KII remains a highly significant predictor after controlling for biogeographic conditions (Columns 2 to 6), religious denomination (Column 7), and mean religiousness (Column 8). Only when controlling for continent fixed effects or in the subsample where all European and European-descent countries are excluded and the geographic baseline set is added (Column 11) do the explanatory variables become insignificant. The signs of the coefficients stay consistently positive, however. The reduced-form association between Western Church exposure and unpaid parking tickets consistently show a negative sign. However, the coefficients are not always significant.

A similar association is found with nepotism (Panel 2). Here, the negative association between Western Church exposure is particularly robust. 

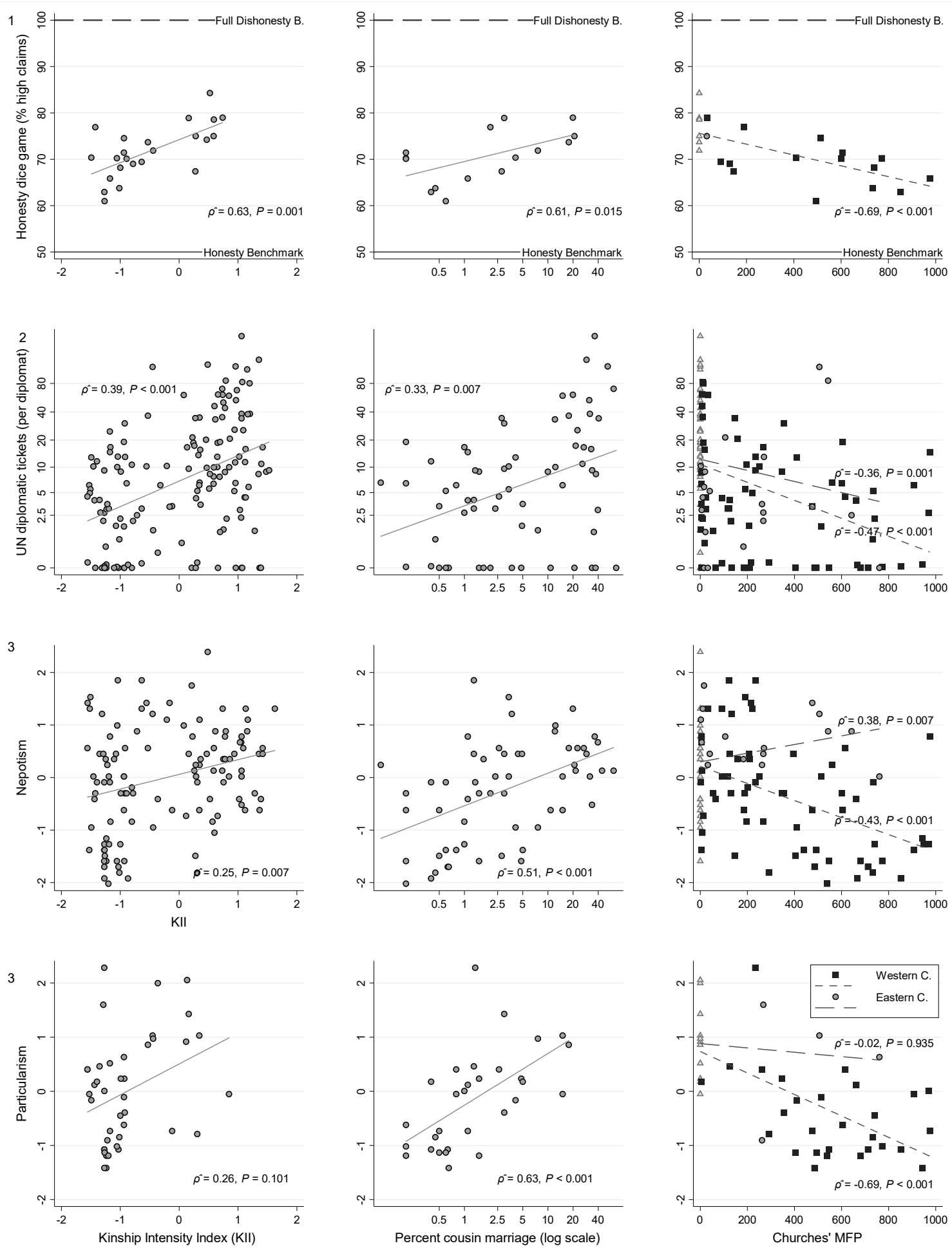

Figure S3.3 Percent high claims (top row), unpaid parking tickets per UN diplomat (second row - log scale), nepotism (third row), and particularism (fourth row) in relation to the KII (first column), percent of cousin marriages (second column), and Church exposure (third column). Linear best-fit lines are displayed; in the third column, countries primarily impacted by the Western Church's MFP are identified with a black square (short-dashed best-fit lines), countries primarily impacted by the Eastern Church's MFP are identified by a grey circle (long-dashed best-fit lines), while triangles denote no Church exposure. Reported are Spearman's $\rho$ and associated significance levels (two-sided). 


\begin{tabular}{|c|c|c|c|c|c|c|c|c|c|c|c|}
\hline & $(1)$ & $(2)$ & $(3)$ & $(4)$ & $(5)$ & $(6)$ & $(7)$ & $(8)$ & $(9)$ & $\begin{array}{l}\text { Non-Ml } \\
(10)\end{array}$ & $\begin{array}{l}\text { sample } \\
(11)\end{array}$ \\
\hline & \multicolumn{11}{|c|}{ Panel 1: Log unpaid parking tickets } \\
\hline KII & $\begin{array}{l}0.60^{* * *} \\
(0.11)\end{array}$ & $\begin{array}{l}0.52^{* * *} \\
(0.13)\end{array}$ & $\begin{array}{l}0.37^{* * *} \\
(0.13)\end{array}$ & $\begin{array}{l}0.45^{* * *} \\
(0.14)\end{array}$ & $\begin{array}{l}0.52^{* * *} \\
(0.14)\end{array}$ & $\begin{array}{l}0.43^{* * *} \\
(0.15)\end{array}$ & $\begin{array}{l}0.45^{* *} \\
(0.20)\end{array}$ & $\begin{array}{l}0.62^{* * *} \\
(0.17)\end{array}$ & $\begin{array}{l}0.21 \\
(0.17)\end{array}$ & $\begin{array}{l}0.45^{* *} \\
(0.21)\end{array}$ & $\begin{array}{l}0.34^{*} \\
(0.20)\end{array}$ \\
\hline$N$ & 141 & 141 & 141 & 141 & 141 & 141 & 141 & 91 & 141 & 82 & 82 \\
\hline$R^{2}$ & 0.172 & 0.205 & 0.289 & 0.216 & 0.205 & 0.211 & 0.271 & 0.271 & 0.265 & 0.049 & 0.087 \\
\hline $\log \%$ cousin $m$. & $\begin{array}{l}0.30^{* * *} \\
(0.11)\end{array}$ & $\begin{array}{l}0.31^{* *} \\
(0.15)\end{array}$ & $\begin{array}{l}0.23 \\
(0.16)\end{array}$ & $\begin{array}{l}0.17 \\
(0.17)\end{array}$ & $\begin{array}{l}0.32^{* *} \\
(0.16)\end{array}$ & $\begin{array}{l}0.13 \\
(0.18)\end{array}$ & $\begin{array}{l}-0.00 \\
(0.25)\end{array}$ & $\begin{array}{l}0.17 \\
(0.16)\end{array}$ & $\begin{array}{l}0.08 \\
(0.21)\end{array}$ & $\begin{array}{l}0.22 \\
(0.23)\end{array}$ & $\begin{array}{l}0.04 \\
(0.25)\end{array}$ \\
\hline$N$ & 64 & 64 & 64 & 64 & 64 & 64 & 64 & 52 & 64 & 31 & 31 \\
\hline$R^{2}$ & 0.133 & 0.146 & 0.200 & 0.191 & 0.148 & 0.193 & 0.292 & 0.226 & 0.238 & 0.022 & 0.135 \\
\hline W. Church exposure & $-0.20^{* * *}$ & $-0.14^{* *}$ & -0.07 & $-0.10^{*}$ & $-0.14^{* *}$ & $-0.12^{* *}$ & -0.04 & -0.07 & -0.01 & & \\
\hline (in 100 yrs.) & $(0.04)$ & $(0.06)$ & $(0.06)$ & $(0.06)$ & $(0.06)$ & $(0.06)$ & $(0.06)$ & $(0.06)$ & $(0.07)$ & & \\
\hline $\begin{array}{l}\text { E. Church exposure } \\
\text { (in } 100 \text { yrs.) }\end{array}$ & $\begin{array}{l}-0.09 \\
(0.12)\end{array}$ & $\begin{array}{l}-0.01 \\
(0.14)\end{array}$ & $\begin{array}{l}0.05 \\
(0.15)\end{array}$ & $\begin{array}{l}-0.00 \\
(0.15)\end{array}$ & $\begin{array}{l}-0.02 \\
(0.15)\end{array}$ & $\begin{array}{l}-0.03 \\
(0.15)\end{array}$ & $\begin{array}{l}0.24 \\
(0.23)\end{array}$ & $\begin{array}{l}0.05 \\
(0.17)\end{array}$ & $\begin{array}{l}0.13 \\
(0.13)\end{array}$ & & \\
\hline$N$ & 137 & 137 & 137 & 137 & 137 & 137 & 137 & 87 & 137 & - & - \\
\hline \multirow[t]{2}{*}{$R^{2}$} & 0.129 & 0.152 & 0.262 & 0.178 & 0.152 & 0.193 & 0.247 & 0.177 & 0.269 & & \\
\hline & \multicolumn{11}{|c|}{ "Panel 2: Nepotism } \\
\hline KII & $\begin{array}{l}0.27^{* * *} \\
(0.09)\end{array}$ & $\begin{array}{l}0.15^{*} \\
(0.09)\end{array}$ & $\begin{array}{l}0.14 \\
(0.09)\end{array}$ & $\begin{array}{l}0.05 \\
(0.09)\end{array}$ & $\begin{array}{l}0.14 \\
(0.09)\end{array}$ & $\begin{array}{l}0.30^{* * *} \\
(0.12)\end{array}$ & $\begin{array}{l}0.17^{*} \\
(0.10)\end{array}$ & $\begin{array}{l}0.21^{*} \\
(0.12)\end{array}$ & $\begin{array}{l}0.25^{* *} \\
(0.12)\end{array}$ & $\begin{array}{l}0.12 \\
(0.15)\end{array}$ & $\begin{array}{l}0.04 \\
(0.14)\end{array}$ \\
\hline$N$ & 108 & 108 & 108 & 108 & 108 & 108 & 108 & 84 & 108 & 48 & 48 \\
\hline$R^{2}$ & 0.066 & 0.286 & 0.286 & 0.340 & 0.298 & 0.357 & 0.593 & 0.399 & 0.343 & 0.013 & 0.161 \\
\hline Log $\%$ cousin $m$. & $\begin{array}{l}0.28^{* * *} \\
(0.06)\end{array}$ & $\begin{array}{l}0.23^{* * *} \\
(0.08)\end{array}$ & $\begin{array}{l}0.23^{* *} \\
(0.09)\end{array}$ & $\begin{array}{l}0.16 \\
(0.11)\end{array}$ & $\begin{array}{l}0.23^{* * *} \\
(0.08)\end{array}$ & $\begin{array}{l}0.28^{* *} \\
(0.13)\end{array}$ & $\begin{array}{l}-0.00 \\
(0.14)\end{array}$ & $\begin{array}{l}0.21^{*} \\
(0.11)\end{array}$ & $\begin{array}{l}0.30^{* *} \\
(0.12)\end{array}$ & $\begin{array}{l}0.17 \\
(0.10)\end{array}$ & $\begin{array}{l}0.07 \\
(0.12)\end{array}$ \\
\hline$N$ & 55 & 55 & 55 & 55 & 55 & 55 & 55 & 47 & 55 & 21 & 21 \\
\hline$R^{2}$ & 0.236 & 0.421 & 0.423 & 0.445 & 0.432 & 0.443 & 0.624 & 0.500 & 0.461 & 0.082 & 0.138 \\
\hline $\begin{array}{l}\text { W. Church exposure } \\
\text { (in } 100 \text { yrs.) }\end{array}$ & $\begin{array}{l}-0.18^{* * *} \\
(0.03)\end{array}$ & $\begin{array}{l}-0.13^{* * *} \\
(0.04)\end{array}$ & $\begin{array}{l}-0.13^{* * *} \\
(0.04)\end{array}$ & $\begin{array}{l}-0.11^{* * *} \\
(0.04)\end{array}$ & $\begin{array}{l}-0.12^{* * *} \\
(0.04)\end{array}$ & $\begin{array}{l}-0.14^{* * *} \\
(0.04)\end{array}$ & $\begin{array}{l}-0.14^{* * *} \\
(0.04)\end{array}$ & $\begin{array}{l}-0.11^{* *} \\
(0.04)\end{array}$ & $\begin{array}{l}-0.14^{* * *} \\
(0.05)\end{array}$ & - & - \\
\hline $\begin{array}{l}\text { E. Church exposure } \\
\text { (in } 100 \text { yrs.) }\end{array}$ & $\begin{array}{l}0.07 \\
(0.05)\end{array}$ & $\begin{array}{l}0.09 \\
(0.07)\end{array}$ & $\begin{array}{l}0.08 \\
(0.07)\end{array}$ & $\begin{array}{l}0.09 \\
(0.07)\end{array}$ & $\begin{array}{l}0.09 \\
(0.07)\end{array}$ & $\begin{array}{l}0.07 \\
(0.07)\end{array}$ & $\begin{array}{l}0.03 \\
(0.06)\end{array}$ & $\begin{array}{l}0.09 \\
(0.07)\end{array}$ & $\begin{array}{l}0.08 \\
(0.09)\end{array}$ & - & - \\
\hline$N$ & 104 & 104 & 104 & 104 & 104 & 104 & 104 & 80 & 104 & - & - \\
\hline$R^{2}$ & 0.318 & 0.402 & 0.404 & 0.437 & 0.404 & 0.450 & 0.630 & 0.476 & 0.441 & & \\
\hline Baseline geo. controls & - & "Yes & "Yes & "Yes & "Yes & "Yes & Y Yes & Yes & "Yes & - & Yes \\
\hline $\begin{array}{l}\text { Parasite stress } \\
\& \text { tropical area }\end{array}$ & - & - & Yes & - & - & - & - & - & - & - & - \\
\hline Irrigation & - & - & - & Yes & - & - & - & - & - & - & - \\
\hline Oats suit. \& Rye suit. & - & - & - & - & Yes & - & - & - & - & - & - \\
\hline $\begin{array}{l}\text { Neolithic. transf. \& } \\
\text { genetic heterogen. }\end{array}$ & - & - & - & - & - & Yes & - & - & - & - & - \\
\hline Major religions & - & - & - & - & - & - & Yes & - & - & - & - \\
\hline Religiousness & - & - & - & - & - & - & - & Yes & - & - & - \\
\hline Continent FE & - & - & - & - & - & - & - & - & Yes & - & - \\
\hline $\begin{array}{l}\text { Table S3.3: Country-le } \\
\text { log percent cousin mar } \\
\text { and dependent variable } \\
\text { caloric suitability, and } \\
\text { Column } 5 \text { for caloric s } \\
\text { ancestor adjusted genet } \\
\text { other Christian, Muslin } \\
\text { Column 9. Columns } 10\end{array}$ & $\begin{array}{l}\text { el regress } \\
\text { lage, and } \\
\text { Regressi } \\
\text { bsolute la } \\
\text { aitability } \mathrm{f} \\
\text { c heteroge } \\
\text { Hindu, } \mathrm{B} \\
\text { and } 11 \mathrm{re}\end{array}$ & $\begin{array}{l}\text { ons of log } \\
\text { Vestern an } \\
\text { ns in Coll } \\
\text { itude). In } \\
\text { r rain-fed } \\
\text { heity; Colu } \\
\text { dddhist); a } \\
\text { ort the reg }\end{array}$ & $\begin{array}{l}\text { Inpaid par } \\
\text { Eastern } \\
\text { mn } 2 \text { to } 9 \\
\text { ddition, } C \\
\text { oats and } \\
\text { nn } 7 \text { for } t \\
\text { id Columr } \\
\text { essions b }\end{array}$ & $\begin{array}{l}\text { ing ticket } \\
\text { hurch exp } \\
\text { and } 11 \mathrm{c} \\
\text { olumn } 3 \mathrm{c} \\
\text { e; Colum } \\
\text { e fraction } \\
8 \text { for (me }\end{array}$ & $\begin{array}{l}\text { per diplor } \\
\text { sure. Eac } \\
\text { ontain the } \\
\text { ntrols for } \\
6 \text { for the } \\
\text { of people } \\
\text { n) importa }\end{array}$ & $\begin{array}{l}\text { at (Panel } \\
\text { column c } \\
\text { et of base } \\
\text { parasite st } \\
\text { ancestor a } \\
\text { dhering to } \\
\text { nce placed } \\
\text { that only }\end{array}$ & $\begin{array}{l}\text { and nepo } \\
\text { ntains } 12 \\
\text { ine contro } \\
\text { ess and tro } \\
\text { djusted tin } \\
\text { major relis } \\
\text { on religior } \\
\text { contains c }\end{array}$ & $\begin{array}{l}\text { ism (Pan } \\
\text { egression } \\
\text { s (rugged } \\
\text { pical area } \\
\text { ing of th } \\
\text { ions (frac } \\
\text { Contine } \\
\text { untries w }\end{array}$ & $\begin{array}{l}\text { 12) on the } \\
\text {, each wit } \\
\text { hess, mear } \\
\text { Column } \\
\text { Neolithic } \\
\text { ion Cathol } \\
\text { t fixed eff } \\
\text { tere were }\end{array}$ & $\begin{array}{l}\text { ship Inte } \\
\text { different } \\
\text { stance to } \\
\text { r irrigatio } \\
\text { insformat } \\
\text { Protestant } \\
\text { are cont } \\
\text { sed to an }\end{array}$ & $\begin{array}{l}\text { ity Index } \\
\text { clanatory } \\
\text { aterways } \\
\text { potential } \\
\text { n and the } \\
\text { Orthodox } \\
\text { lled for in } \\
\text { iverage or }\end{array}$ \\
\hline
\end{tabular}

\section{Impersonal cooperation, fairness and trust}

Our experimental measures of cooperation are based on Herrmann et al. (129). They conducted repeated public goods games (PGG) in the laboratory with and without punishment among undergraduates in 15 societies around the world.

Participants in the PGG without punishment face the following social dilemma: they can either cooperate (i.e., contribute part or all of their endowments to the public good), or refrain from cooperating. The payoff maximizing strategy for the individual is to not cooperate at all, while the social optimum can only be reached if everyone cooperates maximally by contributing his/her entire endowment. Thus, while cooperation is 
individually costly, it benefits the whole group. This PGG without punishment was played repeatedly with the same group of 4 people for 10 periods. Participants faced real financial incentives, which were adjusted to local purchasing power. The rules of the game were the same for all participants. Importantly, the laboratory setting allowed the researchers to control the social distance among participants, which was done by having participants interact anonymously with each other.

Our first measure is $1^{\text {st }}$ round contribution in the PGG without punishment. We use the average contributions of all individuals (as a percentage of the endowment) in the initial round of the game. Initial cooperation is indicative of how participants approach cooperation with anonymous others, before receiving information on the other group members' behavior. This measure likely mixes people's beliefs and internalized motivations for cooperation such specific situations (206). As norm-followers, people cooperate when they believe a cooperative norm exists and that others will follow that norm (207). Our measure of cooperation thus captures how individuals approach cooperation with anonymous others but does not disentangle to what degree this reflects beliefs versus cooperative dispositions. We predict that cooperation is lower in subject-pools exhibiting higher kinship intensity, due to lower trust, belief in the cooperativeness of non-kin, or inclination to cooperate with outsiders.

Our second measure is average contribution in the $P G G$ with punishment. The threat and execution of punishment has been shown to stabilize cooperation in WEIRD societies (208), but this is not universally the case in all societies (129). The basic set-up in the PGG with punishment is very similar to the PGG without punishment. First, individuals decide how much to contribute to the public good. After this initial contribution stage, individuals are informed of the others' decisions and they can set punishment points. Setting punishment points is costly to the punisher but reduces the payment to the recipient of punishment even more. Punishment in this setting can be viewed as the costly enforcement of a social norm. This form of altruistic punishment is itself a second order public good - the costs and benefits of enforcing a social norm are not fully internalized by the punisher, as others are profiting from this norm enforcement as well. We hypothesize that cooperation in the PGG with punishment is lower in societies with high kinship intensity, since in those societies, there is likely no norm demanding the punishment of non-cooperating strangers. In societies with high kinship intensity, there may even exist a norm against forcing cooperative norms onto individuals who do not belong to one's in-group (or, alternatively, there may be no clear norm regarding behavior in a laboratory setting where anonymous others interact, since anonymous interactions hardly ever occur in such societies). Receiving punishment in a repeated setting may spark vendetta-style (antisocial) punishment. Hermann et al. (129) document high levels of antisocial punishment in their repeated PGG among nonWEIRD participants. Pessimistic beliefs that others will cooperate (this time in the presence of a punishment mechanism) and lower cooperative dispositions may further decrease cooperation in the PGG with punishment in societies with high kinship intensity.

Voluntary blood donations per 1,000 inhabitants. To expand our sample, we use a more ecologically relevant variable: countries' frequency of voluntary blood donations per 1,000 inhabitants. Taken from the WHO Global Status on Blood Safety report (see Section S8 for details), this measure captures a real-life public goods contribution: while individually unpleasant, time-consuming, and associated with a small health risk, blood donations benefit anonymous others (that is, out-group members) who are in need. This blood 
donations measure is highly correlated with cooperation in the PGG with punishment (Spearman's $\rho=0.68$, $N=14, P=0.007$ ). While the correlation coefficient between first-period cooperation in the PGG without punishment is also sizeable, it is non-significant in the small overlapping sample (Spearman's $\rho=0.40$, $N=14, P=0.154$ ). Trust (WVS generalized trust question) is correlated with average cooperation in the PGG with punishment (Spearman's $\rho=0.53, N=14, P=0.051$ ).

Our fourth measure is out-ingroup trust. This measure is based on WVS trust questions which are specific about which group of people the respondent trusts. Following Thoeni (209), they can be classified into Outgroup and Ingroup trust. These trust questions are therefore better suited to our analysis of associations with kinship intensity. The questions are posed in the following way: "I'd like to ask you how much you trust people from various groups. Could you tell me for each whether you trust people from this group completely, somewhat, not very much or not at all?" The various groups are (i) the respondent's family, (ii) the respondent's neighbors, (iii) people s/he knowns personally, (iv) people s/he meets for the first time, (v) people of another religion, and (vi) people of another nationality. While the first three questions all relate to people the respondent is relatively familiar with, the latter three questions refer to more unfamiliar people. Our out-group vs. in-group trust measure is constructed by taking the difference between the average of the last three questions (which plausibly capture out-group trust) and the average of the first three questions (which plausibly capture in-group trust). Theoretically the indicator can therefore vary between $-/+12$. We subsequently took country means and standardized the variable. This measure is only available for Waves 5 and 6 of the WVS, covering a total of 77 countries. We hypothesize that higher kinship intensity is associated with a lower out-ingroup trust.

We also report the results for generalized trust and generalized fairness for completeness. Generalized trust is based on responses to the following WVS question: "Generally speaking, would you say that most people can be trusted or that you can't be too careful in dealing with people?" Respondents could choose one of the following two answers: "Cannot be too careful" or "People can be trusted". At the individual level, this question is associated with cooperative dispositions in the PGG (210). Generalized trust is among the most widely studied measures from the WVS. In the context of our study on kinship intensity, the generalized trust measure has one major disadvantage: the question is not specific about the precise "people" it asks whether one can trust or not. It is thus unclear to what degree it captures in-group vs. out-group trust or trust with strangers. In societies with high kinship intensity, "people" might be interpreted as the extended kin-group with whom respondents normally interact. In Section S7, we shed light on this question and find evidence that this is indeed the case. Depending on the kinship intensity the question is understood differently. We nevertheless report the generalized trust measure here since it is a widely used measure. For our European regional analysis (Section S4), our analysis based on children of immigrants (Section S6), and our analysis leveraging within-country variation using WVS data (Section S7), we employ very similar or identical generalized trust measures. ${ }^{42}$ In Section S7 we provide empirical evidence that this is justified in more homogenous regions (that is, within countries) and particularly within Europe. There the generalized trust question relates to impersonal trust, that is, trust in strangers.

\footnotetext{
${ }^{42}$ The difference between the WVS generalized trust question and the ESS one is that while the former is a binary measure, the latter rests on an 11-point scale.
} 
Generalized fairness. The WVS contains a question about respondents' fairness perceptions: "Do you think that most people would try to take advantage of you if they got the chance, or would they try to be fair?" Respondent answer on an 11-point scale, and again we use standardized country averages. Its limitation is similar to that of the generalized trust measure: it does not precisely define who "most people" refers to, so this question might be understood differently depending on the cultural background. Again, this issue is most likely less severe for within-country analyses in Europe, as the cultural background is more similar (see Section S7). Here we nonetheless report the cross-country results for completeness.

Figure S3.4 shows the association between the KII, cousin marriage, and Church exposure on the one hand, and these six outcome variables on the other. Most associations are highly significant in the expected direction. Not surprisingly, no association is found for generalized trust and fairness, the two measures that don't define the reference groups precisely. 

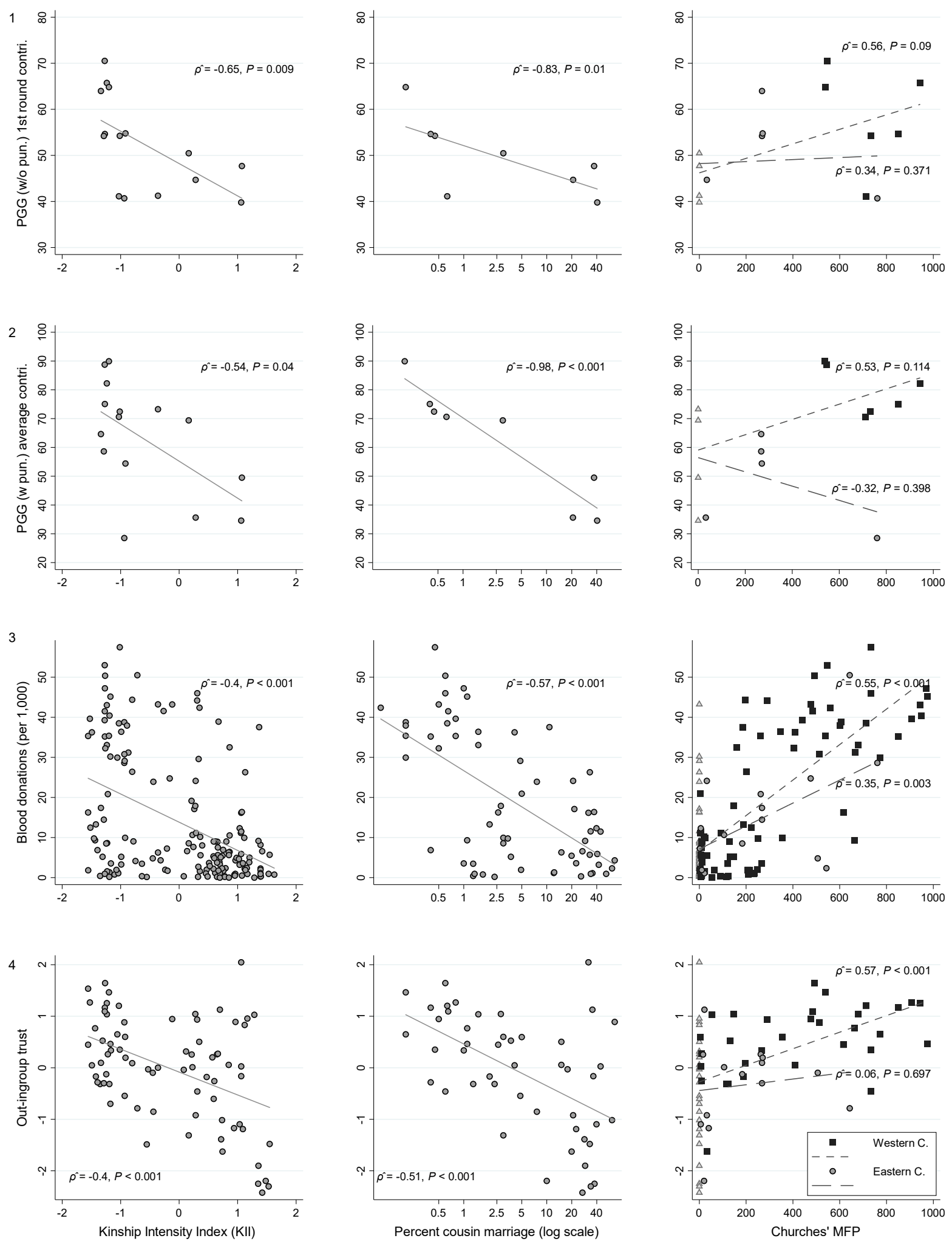

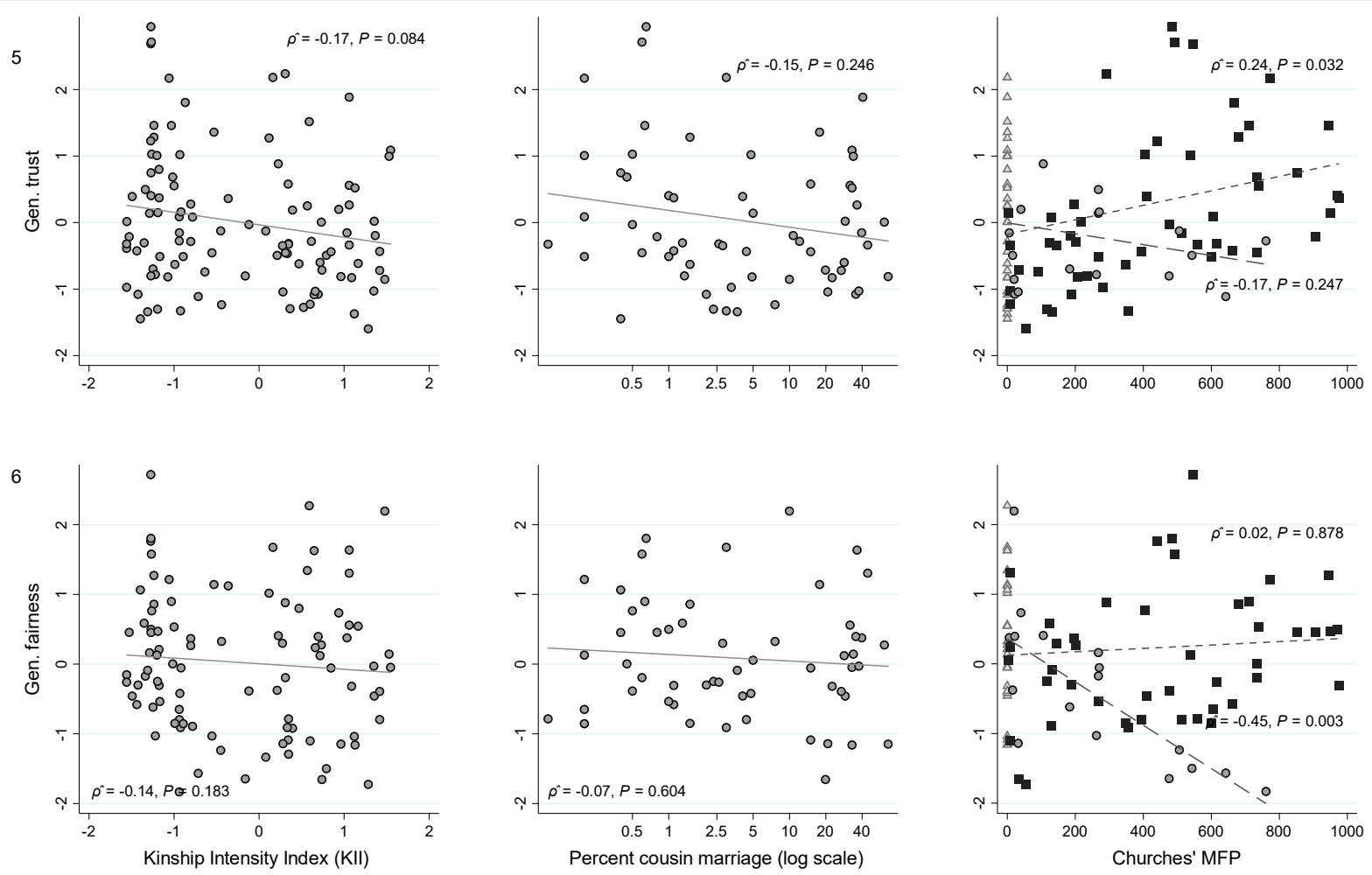

Figure S3.4: KII (first column), percent cousin marriages (second column), and Church exposure (third column) in relation to first period contribution in the PGG without punishment (percentage of endowment, top row), average contribution in the PGG with punishment (percentage of endowment, second row), voluntary blood donations (third row), out-ingroup trust (fourth row), generalized trust (fifth row), and generalized fairness (sixth row). Linear best-fit lines are displayed; in the third column, countries primarily impacted by the Western Church's MFP are identified with a black square (short-dashed best-fit lines), countries primarily impacted by the Eastern Church's MFP are identified by a grey circle (long-dashed best-fit lines), while triangles denote no Church exposure. Reported are Spearman's $\rho$ and associated significance levels (two-sided).

Tables S3.4A and S3.4B report our regression results. Given the small number of countries for which our behavioral measures of cooperation (with and without punishment) are available $(\mathrm{N}=15)$, we do not report results from regressions of those measures. Each column reports the results from three separate regressions: one regression with KII as the explanatory variable of interest, one with log percent cousin marriage, and one with Church exposure. 


\begin{tabular}{|c|c|c|c|c|c|c|c|c|c|c|c|}
\hline & \multirow[b]{2}{*}{$(1)$} & \multirow[b]{2}{*}{$(2)$} & \multirow[b]{2}{*}{$(3)$} & \multirow[b]{2}{*}{$(4)$} & \multirow[b]{2}{*}{$(5)$} & \multirow[b]{2}{*}{$(6)$} & \multirow[b]{2}{*}{ (7) } & \multirow[b]{2}{*}{$(8)$} & \multirow[b]{2}{*}{$(9)$} & \multicolumn{2}{|c|}{ Non-MFP sample } \\
\hline & & & & & & & & & & $(10)$ & $(11)$ \\
\hline & \multicolumn{11}{|c|}{ Panel 1: Voluntary blood donations (per 1,000 inhabitants) } \\
\hline KII & $\begin{array}{l}-7.50^{* * *} \\
(1.21)\end{array}$ & $\begin{array}{l}-2.84^{* * *} \\
(1.06)\end{array}$ & $\begin{array}{l}-2.20^{*} \\
(1.15)\end{array}$ & $\begin{array}{l}-2.23^{*} \\
(1.17)\end{array}$ & $\begin{array}{l}-2.80^{* * *} \\
(1.03)\end{array}$ & $\begin{array}{l}-4.75^{* * *} \\
(1.44)\end{array}$ & $\begin{array}{l}-2.35 \\
(2.03)\end{array}$ & $\begin{array}{l}-2.03 \\
(1.66)\end{array}$ & $\begin{array}{l}-3.08^{* *} \\
(1.37)\end{array}$ & $\begin{array}{l}-3.27^{*} \\
(1.84)\end{array}$ & $\begin{array}{l}-2.78 \\
(1.69)\end{array}$ \\
\hline$N$ & 138 & 138 & 138 & 138 & 138 & 138 & 138 & 85 & 138 & 79 & 79 \\
\hline$R^{2}$ & 0.222 & 0.547 & 0.580 & 0.557 & 0.578 & 0.574 & 0.606 & 0.554 & 0.612 & 0.085 & 0.218 \\
\hline Log $\%$ cousin $m$. & $\begin{array}{l}-5.70^{* * *} \\
(0.73)\end{array}$ & $\begin{array}{l}-2.06^{* *} \\
(0.91)\end{array}$ & $\begin{array}{l}-1.56 \\
(0.95)\end{array}$ & $\begin{array}{l}-1.97 \\
(1.21)\end{array}$ & $\begin{array}{l}-2.16^{* *} \\
(0.88)\end{array}$ & $\begin{array}{l}-3.91^{* * *} \\
(1.14)\end{array}$ & $\begin{array}{l}-1.95 \\
(1.73)\end{array}$ & $\begin{array}{l}-1.92^{*} \\
(0.95)\end{array}$ & $\begin{array}{l}-1.50 \\
(1.29)\end{array}$ & $\begin{array}{l}-0.81 \\
(1.37)\end{array}$ & $\begin{array}{l}-0.21 \\
(1.31)\end{array}$ \\
\hline$N$ & 62 & 62 & 62 & 62 & 62 & 62 & 62 & 50 & 62 & 28 & 28 \\
\hline$R^{2}$ & 0.390 & 0.684 & 0.744 & 0.684 & 0.702 & 0.719 & 0.725 & 0.711 & 0.752 & 0.012 & 0.168 \\
\hline $\begin{array}{l}\text { W. Church exposure } \\
\text { (in } 100 \text { yrs.) }\end{array}$ & $\begin{array}{l}4.39^{* * *} \\
(0.32)\end{array}$ & $\begin{array}{l}2.77^{* * *} \\
(0.46)\end{array}$ & $\begin{array}{l}2.42^{* * *} \\
(0.49)\end{array}$ & $\begin{array}{l}2.65^{* * *} \\
(0.48)\end{array}$ & $\begin{array}{l}2.55^{* * *} \\
(0.48)\end{array}$ & $\begin{array}{l}2.74^{* * *} \\
(0.48)\end{array}$ & $\begin{array}{l}3.23^{* * *} \\
(0.52)\end{array}$ & $\begin{array}{l}2.21^{* * *} \\
(0.59)\end{array}$ & $\begin{array}{l}3.11^{* * *} \\
(0.51)\end{array}$ & - & - \\
\hline $\begin{array}{l}\text { E. Church exposure } \\
\text { (in } 100 \text { yrs.) }\end{array}$ & $\begin{array}{l}3.13^{* * *} \\
(1.08)\end{array}$ & $\begin{array}{l}1.21 \\
(1.45)\end{array}$ & $\begin{array}{l}0.70 \\
(1.49)\end{array}$ & $\begin{array}{l}1.21 \\
(1.45)\end{array}$ & $\begin{array}{l}0.79 \\
(1.47)\end{array}$ & $\begin{array}{l}0.84 \\
(1.46)\end{array}$ & $\begin{array}{l}1.21 \\
(2.79)\end{array}$ & $\begin{array}{l}0.53 \\
(1.74)\end{array}$ & $\begin{array}{l}0.82 \\
(0.92)\end{array}$ & - & - \\
\hline$N$ & 135 & 135 & 135 & 135 & 135 & 135 & 134 & 82 & 135 & & \\
\hline \multirow[t]{2}{*}{$R^{2}$} & 0.564 & 0.661 & 0.675 & 0.666 & 0.673 & 0.671 & 0.710 & 0.641 & 0.714 & & \\
\hline & \multicolumn{11}{|c|}{ Panel 2: Out-ingroup trust } \\
\hline KII & $\begin{array}{l}-0.47^{* * *} \\
(0.12)\end{array}$ & $\begin{array}{l}-0.40^{* * *} \\
(0.12)\end{array}$ & $\begin{array}{l}-0.34^{* *} \\
(0.14)\end{array}$ & $\begin{array}{l}-0.23^{*} \\
(0.14)\end{array}$ & $\begin{array}{l}-0.37^{* * *} \\
(0.12)\end{array}$ & $\begin{array}{l}-0.54^{* * *} \\
(0.14)\end{array}$ & $\begin{array}{l}-0.22 \\
(0.13)\end{array}$ & $\begin{array}{l}-0.36^{* *} \\
(0.13)\end{array}$ & $\begin{array}{l}-0.21 \\
(0.16)\end{array}$ & $\begin{array}{l}-0.28 \\
(0.18)\end{array}$ & $\begin{array}{l}0.04 \\
(0.18)\end{array}$ \\
\hline$N$ & 70 & 70 & 70 & 70 & 70 & 70 & 70 & 70 & 70 & 35 & 35 \\
\hline$R^{2}$ & 0.236 & 0.271 & 0.303 & 0.359 & 0.343 & 0.345 & 0.590 & 0.279 & 0.344 & 0.053 & 0.380 \\
\hline Log $\%$ cousin $m$. & $\begin{array}{l}-0.39^{* * *} \\
(0.08)\end{array}$ & $\begin{array}{l}-0.32^{* * *} \\
(0.11)\end{array}$ & $\begin{array}{l}-0.26^{*} \\
(0.14)\end{array}$ & $\begin{array}{l}-0.17 \\
(0.14)\end{array}$ & $\begin{array}{l}-0.27^{* *} \\
(0.11)\end{array}$ & $\begin{array}{l}-0.35^{* *} \\
(0.14)\end{array}$ & $\begin{array}{l}0.44^{* *} \\
(0.17)\end{array}$ & $\begin{array}{l}-0.31^{* *} \\
(0.13)\end{array}$ & $\begin{array}{l}-0.13 \\
(0.15)\end{array}$ & $\begin{array}{l}-0.05 \\
(0.14)\end{array}$ & $\begin{array}{l}0.22 \\
(0.14)\end{array}$ \\
\hline$N$ & 44 & 44 & 44 & 44 & 44 & 44 & 44 & 44 & 44 & 23 & 23 \\
\hline$R^{2}$ & 0.368 & 0.403 & 0.440 & 0.488 & 0.517 & 0.408 & 0.761 & 0.403 & 0.456 & 0.003 & 0.455 \\
\hline W. Church exposure & $0.18^{* * *}$ & $0.18^{* * *}$ & $0.19^{* * *}$ & $0.15^{* * *}$ & $0.19^{* * *}$ & $0.18^{* * *}$ & $0.10^{* *}$ & $0.17^{* * *}$ & 0.08 & & \\
\hline (in 100 yrs.) & $(0.03)$ & $(0.04)$ & $(0.04)$ & $(0.04)$ & $(0.04)$ & $(0.04)$ & $(0.04)$ & $(0.04)$ & $(0.06)$ & & \\
\hline E. Church exposure & 0.05 & 0.02 & 0.04 & -0.01 & 0.07 & 0.04 & -0.13 & 0.02 & -0.15 & & \\
\hline (in 100 yrs.) & $(0.07)$ & $(0.06)$ & $(0.06)$ & $(0.06)$ & $(0.06)$ & $(0.06)$ & $(0.14)$ & $(0.06)$ & $(0.14)$ & & \\
\hline$N$ & 67 & 67 & 67 & 67 & 67 & 67 & 67 & 67 & 67 & - & - \\
\hline$R^{2}$ & 0.298 & 0.364 & 0.441 & 0.476 & 0.436 & 0.407 & 0.610 & 0.369 & 0.411 & & \\
\hline Baseline geo. controls & - & Yes & Yes & Yes & Yes & Yes & Yes & Yes & Yes & - & Yes \\
\hline $\begin{array}{l}\text { Parasite stress } \\
\& \text { tropical area }\end{array}$ & - & - & Yes & - & - & - & - & - & - & - & - \\
\hline Irrigation & - & - & - & Yes & - & - & - & - & - & - & - \\
\hline Oats suit. \& Rye suit. & - & - & - & - & Yes & - & - & - & - & - & - \\
\hline $\begin{array}{l}\text { Neolithic. transf. \& } \\
\text { genetic heterogen. }\end{array}$ & - & - & - & - & - & Yes & - & - & - & - & - \\
\hline Major religions & - & - & - & - & - & - & Yes & - & - & - & - \\
\hline Religiousness & - & - & - & - & - & - & - & Yes & - & - & - \\
\hline Continent FE & - & - & - & - & - & - & - & - & Yes & - & - \\
\hline
\end{tabular}

Table S3.4A: Country-level regressions of voluntary blood donation (per 1,000 inhabitants) and out-ingroup trust on the Kinship Intensity Index, log percent cousin marriage, and Western and Eastern Church exposure. Each column contains 4 regressions, each with a different explanatory variable. Regressions in Column 2-9 and 11 contain the set of baseline controls (ruggedness, mean distance to waterways, caloric suitability, and absolute latitude). In addition, Column 3 controls for parasite stress and percent tropical area; Column 4 for irrigation potential; Column 5 for caloric suitability for rain-fed oats and rye; Column 6 for the ancestor-adjusted timing of the Neolithic Transformation and ancestor-adjusted genetic heterogeneity; Column 7 for the fraction of people adhering to major religions (fraction Catholic, Protestant, Orthodox, other Christian denominations, Muslim, Hindu, Buddhist); and Column 8 for (mean) religiousness. Continent fixed effects are controlled for in Column 9. Columns 10 and 11 report the regressions based on the subsample that only contains countries where ancestors were exposed to an average of no more than 120 years of the medieval Churches' MFP. Robust standard errors (in parentheses), the number of observations $(N)$, and $R$-squared for each regression are reported. * $P \leq 0.1, * * P \leq 0.05, * * * \mathrm{P} \leq 0.01$ (two-sided). 


\begin{tabular}{|c|c|c|c|c|c|c|c|c|c|c|c|}
\hline & \multirow[b]{2}{*}{$(1)$} & \multirow[b]{2}{*}{$(2)$} & \multirow[b]{2}{*}{ (3) } & \multirow[b]{2}{*}{ (4) } & \multirow[b]{2}{*}{ (5) } & \multirow[b]{2}{*}{$(6)$} & \multirow[b]{2}{*}{$(7)$} & \multirow[b]{2}{*}{$(8)$} & \multirow[b]{2}{*}{ (9) } & \multicolumn{2}{|c|}{ Non-MFP sample } \\
\hline & & & & & & & & & & $(10)$ & (11) \\
\hline & \multicolumn{11}{|c|}{ Panel 1: Generalized trust } \\
\hline KII & $-0.22^{* *}$ & $-0.17^{*}$ & -0.15 & -0.14 & -0.15 & -0.11 & $-0.28^{* *}$ & 0.03 & $-0.32^{* *}$ & -0.03 & -0.25 \\
\hline & $(0.10)$ & $(0.10)$ & $(0.10)$ & $(0.10)$ & $(0.10)$ & $(0.13)$ & $(0.14)$ & $(0.11)$ & $(0.13)$ & $(0.22)$ & $(0.28)$ \\
\hline$N$ & 96 & 96 & 96 & 96 & 96 & 96 & 96 & 95 & 96 & 41 & 41 \\
\hline$R^{2}$ & 0.043 & 0.386 & 0.397 & 0.388 & 0.420 & 0.390 & 0.645 & 0.509 & 0.482 & 0.001 & 0.169 \\
\hline Log $\%$ cousin $m$. & -0.11 & -0.05 & -0.03 & -0.01 & -0.03 & 0.01 & -0.01 & 0.11 & -0.06 & 0.12 & 0.08 \\
\hline & $(0.07)$ & $(0.08)$ & $(0.10)$ & $(0.10)$ & $(0.08)$ & $(0.11)$ & $(0.13)$ & $(0.08)$ & $(0.12)$ & $(0.21)$ & $(0.26)$ \\
\hline$N$ & 56 & 56 & 56 & 56 & 56 & 56 & 56 & 55 & 56 & 26 & 26 \\
\hline$R^{2}$ & 0.040 & 0.368 & 0.391 & 0.376 & 0.397 & 0.385 & 0.577 & 0.485 & 0.460 & 0.020 & 0.034 \\
\hline W. Church exposure & $0.12^{* * *}$ & 0.04 & 0.04 & 0.03 & 0.05 & 0.03 & $0.08^{* *}$ & -0.02 & 0.06 & & \\
\hline (in $100 \mathrm{yrs}$. ) & $(0.03)$ & $(0.04)$ & $(0.04)$ & $(0.04)$ & $(0.04)$ & $(0.04)$ & $(0.03)$ & $(0.03)$ & $(0.05)$ & & \\
\hline E. Church exposure & -0.03 & -0.11 & -0.09 & -0.11 & -0.07 & -0.09 & -0.01 & $-0.11^{* *}$ & -0.07 & & \\
\hline (in 100 yrs.) & $(0.04)$ & $(0.06)$ & $(0.06)$ & $(0.06)$ & $(0.06)$ & $(0.06)$ & $(0.07)$ & $(0.05)$ & $(0.09)$ & & \\
\hline$N$ & 92 & 92 & 92 & 92 & 92 & 92 & 92 & 91 & 92 & - & - \\
\hline \multirow[t]{2}{*}{$R^{2}$} & 0.134 & 0.407 & 0.423 & 0.411 & 0.443 & 0.422 & 0.645 & 0.524 & 0.501 & & \\
\hline & \multicolumn{11}{|c|}{ Panel 2: Generalized fairness } \\
\hline KII & -0.07 & $-0.19^{*}$ & -0.13 & -0.14 & $-0.18^{*}$ & 0.02 & -0.08 & 0.00 & $-0.40^{* * *}$ & -0.15 & -0.36 \\
\hline & $(0.11)$ & $(0.11)$ & $(0.13)$ & $(0.12)$ & $(0.11)$ & $(0.17)$ & $(0.17)$ & $(0.13)$ & $(0.14)$ & $(0.17)$ & $(0.22)$ \\
\hline$N$ & 86 & 86 & 86 & 86 & 86 & 86 & 86 & 86 & 86 & 36 & 36 \\
\hline$R^{2}$ & 0.005 & 0.200 & 0.218 & 0.207 & 0.224 & 0.258 & 0.470 & 0.327 & 0.325 & 0.015 & 0.138 \\
\hline Log $\%$ cousin $m$. & -0.05 & $-0.14^{*}$ & -0.03 & -0.11 & -0.13 & -0.06 & -0.01 & -0.05 & $-0.23^{* *}$ & -0.21 & $-0.39^{* *}$ \\
\hline & $(0.07)$ & $(0.08)$ & $(0.09)$ & $(0.10)$ & $(0.08)$ & $(0.09)$ & $(0.18)$ & $(0.10)$ & $(0.10)$ & $(0.13)$ & $(0.15)$ \\
\hline$N$ & 51 & 51 & 51 & 51 & 51 & 51 & 51 & 51 & 51 & 24 & 24 \\
\hline$R^{2}$ & 0.011 & 0.299 & 0.377 & 0.306 & 0.322 & 0.345 & 0.430 & 0.368 & 0.497 & 0.064 & 0.298 \\
\hline W. Church exposure & 0.02 & 0.02 & 0.01 & 0.01 & 0.03 & 0.02 & 0.03 & -0.03 & 0.06 & & \\
\hline (in 100 yrs.) & $(0.03)$ & $(0.03)$ & $(0.04)$ & $(0.04)$ & $(0.04)$ & $(0.03)$ & $(0.04)$ & $(0.03)$ & $(0.05)$ & & \\
\hline E. Church exposure & $-0.26^{* * *}$ & $-0.23^{* * *}$ & $-0.24^{* * *}$ & $-0.24^{* * *}$ & $-0.22^{* * *}$ & $-0.21^{* * *}$ & $-0.26^{* * *}$ & $-0.23^{* * *}$ & $-0.20^{* *}$ & & \\
\hline (in 100 yrs.) & $(0.04)$ & $(0.06)$ & $(0.06)$ & $(0.06)$ & $(0.06)$ & $(0.05)$ & $(0.07)$ & $(0.05)$ & $(0.10)$ & & \\
\hline$N$ & 82 & 82 & 82 & 82 & 82 & 82 & 82 & 82 & 82 & - & - \\
\hline$R^{2}$ & 0.179 & 0.302 & 0.326 & 0.316 & 0.316 & 0.342 & 0.508 & 0.437 & 0.398 & & \\
\hline "Baseline geo. controls & - & Yes & Yes & Yes & Yes & Yes & Yes & Yes & Yes & - & Yes \\
\hline $\begin{array}{l}\text { Parasite stress } \\
\text { \& tropical area }\end{array}$ & - & - & Yes & - & - & - & - & - & - & - & - \\
\hline Irrigation & - & - & - & Yes & - & - & - & - & - & - & - \\
\hline Oats suit. \& Rye suit. & - & - & - & - & Yes & - & - & - & - & - & - \\
\hline $\begin{array}{l}\text { Neolithic. transf. \& } \\
\text { genetic heterogen. }\end{array}$ & - & - & - & - & - & Yes & - & - & - & - & - \\
\hline Major religions & - & - & - & - & - & - & Yes & - & - & - & - \\
\hline Religiousness & - & - & - & - & - & - & - & Yes & - & - & - \\
\hline Continent FE & - & - & - & - & - & - & - & - & Yes & - & - \\
\hline
\end{tabular}

Table S3.4B: Country-level regressions of out-ingroup trust (Panel 1), generalized trust (Panel 2), and generalized fairness (Panel 3) on the Kinship Intensity Index, log percent cousin marriage, and Western and Eastern Church exposure. Each panel contains 12 regressions, each with a different explanatory and dependent variable. Regressions in column 2 to 9, and 11 contain the set of baseline controls (ruggedness, mean distance to waterways, caloric suitability, and absolute latitude). In addition, Column 3 controls for parasite stress and tropical area; Column 4 for irrigation potential; Column 5 for caloric suitability for rain-fed oats and rye; Column 6 for the ancestor adjusted timing of the Neolithic Transformation and the ancestor adjusted genetic heterogeneity; Column 7 for the fraction of people adhering to major religions (fraction Catholic, Protestant, Orthodox, other Christian, Muslim, Hindu, Buddhist); and Column 8 for (mean) importance placed on religion. Continent fixed effects are controlled for in Column 9. Columns 10 and 11 report the regressions based on the sub-sample that only contains countries where ancestors were exposed to an average of no more than 120 years of the medieval Churches' MFP. Robust standard errors are reported in parentheses, as well as the number of observations and $\mathrm{R}$-squared for each regression. $* P \leq 0.1, * * P \leq 0.05, * * * \mathrm{P} \leq 0.01$ (two-sided).

The regression analysis confirms the findings of Figure S3.4. Kinship intensity, as measured both by the KII and log percent cousin marriage, is highly significantly negatively associated with blood donations. A onestandard-deviation increase in the KII decreases blood donations (per 1000 inhabitants) by 7.5. Doubling the prevalence of cousin marriages (an increase of 100\%) decreases blood donations by about 4 units per 1000 inhabitants $(4 \approx 5.70 \cdot \ln (2))$. When introducing the controls, the signs of all coefficients that measure kinship intensity consistently stay negative. The coefficients decrease once we control for our baseline set of covariates. Yet, the coefficient on the KII and on log percent cousin marriage remain significant at least at the 5\% level. Adding further controls for deep biogeographic variables like the timing of the Neolithic Transformation, genetic heterogeneity, caloric suitability for oats and rye does not affect the estimates very 
much. While all coefficients exhibit the expected signs, the estimations are not robust to controlling for the population share of major religions. This is hardly surprising giving the high correlation between the Church's MFP and the share of major religions. The estimation results are also not robust to controlling for the countries' mean religiousness. This may reflect distrust in technology (e.g., rather than seeing the benefit in curing disease by blood transfusion more weight may be placed on miracles by God). Moreover, religiousness might itself be an outcome of kinship intensity. Once people become more individualistic they place less weight on religion. This might decrease the coefficients for kinship intensity and increase the uncertainty in the estimates. However, in this regression, the sample size is also reduced. Columns 9-11 reveal that the relationship holds when controlling for continent fixed effects and in the sub-sample where we excluded countries where the average ancestor experienced more than 120 years of Church exposure. In Section S5, we replicate the association between kinship intensity (proxied by cousin marriages) and blood donations, using data on Italian provinces.

The reduced-form association demonstrates that Western Church exposure is likewise a highly significant predictor of blood donations in all specification. Suitability for oats and rye also does not change the coefficient much, suggesting that we are not picking up an effect of a medieval agricultural revolution in Europe. Consistent with the hypothesis that the MFP was more comprehensive and enforcement stronger under the Western Church, the coefficient on Eastern Church exposure is only significant in the specification without the baseline controls (Column 1).

Kinship intensity is likewise quite robustly associated with out-ingroup trust. Unsurprisingly the association between kinship intensity and generalized trust or generalized fairness is less robust. Depending on a country's kinship intensity, the generalized trust and generalized fairness questions may be understood quite differently. The analysis shows though that in specifications that controlling for continent fixed effects the association is significant. We discuss this in more detail in Section S7.

\section{(4) Family ties}

In a series of papers, Alesina and Giuliano (134-136) have demonstrated the importance of family ties for important economic outcomes like home production, labor force participation of women and young adults, generalized trust and political participation. Their family ties measure captures attitudes towards the nuclear family. It is based on three questions from the WVS. The first question asks how important the family is, on a scale ranging from " 1 . Very important" to "4. Not important at all". The second question asks respondents to choose one out of two statements: "Regardless of what the qualities and faults of one's parents are, one must always love and respect them" or "One does not have the duty to respect and love parents who have not earned it". The third question asks respondents to choose one of the following two statements: "It is the parents' duty to do their best for their children even at the expense of their own well-being" or "Parents have a life of their own and should not be asked to sacrifice their own well-being for the sake of their children." The measure of family ties is based on the first principal component of the responses to those three questions. Our theory predicts that greater kinship intensity or less Church exposure will be associated with stronger family ties. Investing in offspring as well as respect for parents (and other elders) is an important component of this. 

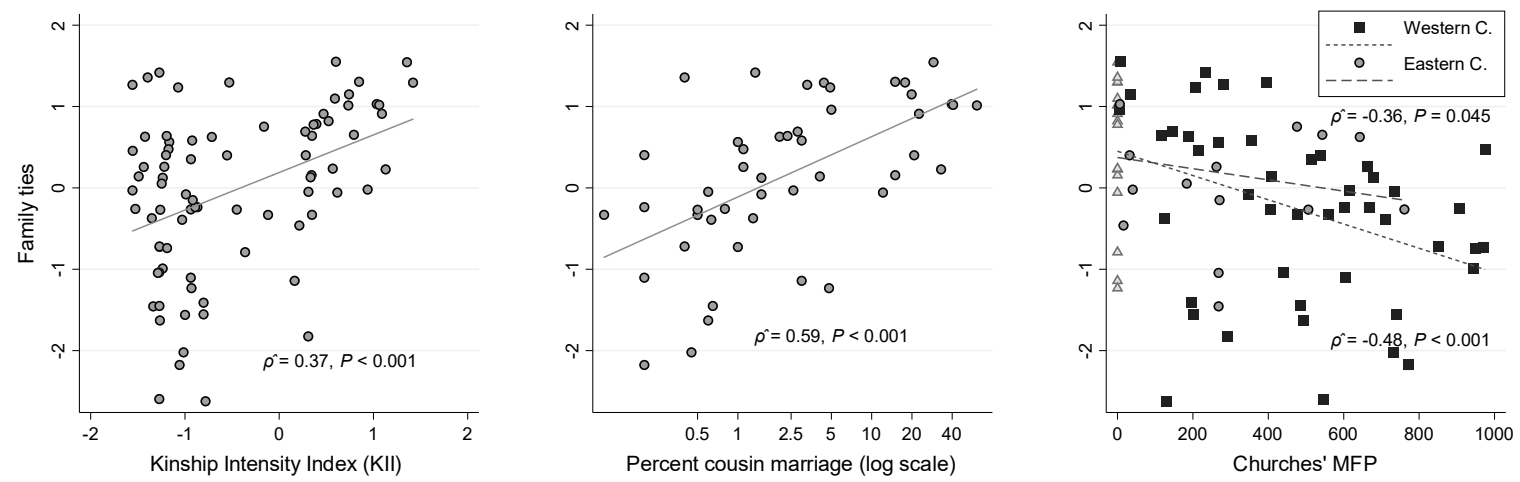

Figure S3.5: Kinship Intensity Index (first column), percentage of cousin marriages (second column), and Church exposure (third column) in relation to family ties. Linear best-fit lines are displayed; in the third column, countries primarily impacted by the Western Church's MFP are identified with a black square (short-dashed best-fit lines), countries primarily impacted by the Eastern Church's MFP are identified by a grey circle (long-dashed best-fit lines), while triangles denote no Church exposure. Reported are Spearman's $\rho$ and associated significance levels (two-sided).

Figure S3.5 illustrates the positive association between family ties and kinship intensity. The association between family ties and the KII and percent cousin marriages is positive, whereas it is negative between free will and Church exposure. Table S3.5 shows that the association between KII and family ties is more or less robust to the inclusion of additional covariates.

\begin{tabular}{|c|c|c|c|c|c|c|c|c|c|c|c|}
\hline & \multicolumn{11}{|c|}{ Family ties } \\
\hline & \multirow[b]{2}{*}{ (1) } & \multirow[b]{2}{*}{ (2) } & \multirow[b]{2}{*}{ (3) } & \multirow[b]{2}{*}{ (4) } & \multirow[b]{2}{*}{ (5) } & \multirow[b]{2}{*}{ (6) } & \multirow[b]{2}{*}{ (7) } & \multirow[b]{2}{*}{ (8) } & \multirow[b]{2}{*}{ (10) } & \multicolumn{2}{|c|}{ Non-MFP Sample } \\
\hline & & & & & & & & & & $(11)$ & (12) \\
\hline KII & $\begin{array}{l}0.16^{* * *} \\
(0.04)\end{array}$ & $\begin{array}{l}0.08^{* * *} \\
(0.03)\end{array}$ & $\begin{array}{l}0.07^{* *} \\
(0.03)\end{array}$ & $\begin{array}{l}0.05 \\
(0.03)\end{array}$ & $\begin{array}{l}0.08^{* *} \\
(0.03)\end{array}$ & $\begin{array}{l}0.04 \\
(0.04)\end{array}$ & $\begin{array}{l}0.07^{*} \\
(0.04)\end{array}$ & $\begin{array}{l}0.02 \\
(0.03)\end{array}$ & $\begin{array}{l}0.11^{* *} \\
(0.05)\end{array}$ & $\begin{array}{l}0.11 \\
(0.10)\end{array}$ & $\begin{array}{l}0.19^{* *} \\
(0.07)\end{array}$ \\
\hline$N$ & 75 & 75 & 75 & 75 & 75 & 75 & 75 & 75 & 75 & 23 & 23 \\
\hline$R^{2}$ & 0.162 & 0.588 & 0.605 & 0.612 & 0.589 & 0.614 & 0.727 & 0.724 & 0.613 & 0.079 & 0.696 \\
\hline Log $\%$ cousin $m$. & $\begin{array}{l}0.11^{* * *} \\
(0.02)\end{array}$ & $\begin{array}{l}0.04 \\
(0.02)\end{array}$ & $\begin{array}{l}0.04 \\
(0.03)\end{array}$ & $\begin{array}{l}0.02 \\
(0.03)\end{array}$ & $\begin{array}{l}0.04 \\
(0.02)\end{array}$ & $\begin{array}{l}0.00 \\
(0.03)\end{array}$ & $\begin{array}{l}0.07^{* *} \\
(0.03)\end{array}$ & $\begin{array}{l}-0.01 \\
(0.02)\end{array}$ & $\begin{array}{l}0.05 \\
(0.03)\end{array}$ & $\begin{array}{l}0.06 \\
(0.08)\end{array}$ & $\begin{array}{l}0.08 \\
(0.06)\end{array}$ \\
\hline$N$ & 44 & 44 & 44 & 44 & 44 & 44 & 44 & 44 & 44 & 16 & 16 \\
\hline$R^{2}$ & 0.328 & 0.603 & 0.609 & 0.629 & 0.610 & 0.681 & 0.815 & 0.795 & 0.662 & 0.069 & 0.679 \\
\hline $\begin{array}{l}\text { W. Church exposure } \\
\text { (in } 100 \text { yrs.) }\end{array}$ & $\begin{array}{l}-0.05^{* * *} \\
(0.01)\end{array}$ & $\begin{array}{l}0.00 \\
(0.01)\end{array}$ & $\begin{array}{l}0.00 \\
(0.01)\end{array}$ & $\begin{array}{l}0.01 \\
(0.01)\end{array}$ & $\begin{array}{l}0.00 \\
(0.01)\end{array}$ & $\begin{array}{l}-0.00 \\
(0.01)\end{array}$ & $\begin{array}{l}0.01 \\
(0.02)\end{array}$ & $\begin{array}{l}0.02^{*} \\
(0.01)\end{array}$ & $\begin{array}{l}0.01 \\
(0.02)\end{array}$ & & \\
\hline E. Church exposure & -0.03 & 0.03 & 0.03 & 0.03 & 0.03 & 0.02 & 0.01 & 0.03 & $0.06^{*}$ & & \\
\hline (in 100 yrs.) & $(0.02)$ & $(0.02)$ & $(0.02)$ & $(0.02)$ & $(0.02)$ & $(0.02)$ & $(0.05)$ & $(0.02)$ & $(0.03)$ & & \\
\hline$N$ & 72 & 72 & 72 & 72 & 72 & 72 & 72 & 72 & 72 & & \\
\hline$R^{2}$ & 0.168 & 0.585 & 0.615 & 0.631 & 0.591 & 0.624 & 0.724 & 0.739 & 0.620 & & \\
\hline Baseline geo. controls & - & Yes & Yes & Yes & Yes & Yes & Yes & Yes & Yes & - & Yes \\
\hline $\begin{array}{l}\text { Parasite stress } \\
\& \text { tropical area }\end{array}$ & - & - & Yes & - & - & - & - & - & - & - & - \\
\hline Irrigation & - & - & - & Yes & - & - & - & - & - & - & - \\
\hline Oats suit. \& Rye suit. & - & - & - & - & Yes & - & - & - & - & - & - \\
\hline $\begin{array}{l}\text { Neolithic. transf. \& } \\
\text { genetic heterogen. }\end{array}$ & - & - & - & - & - & Yes & - & - & - & - & - \\
\hline Major religions & - & - & - & - & - & - & Yes & - & - & - & - \\
\hline Religiousness & - & - & - & - & - & - & - & Yes & - & - & - \\
\hline Continent FE & - & - & - & - & - & - & - & - & Yes & - & - \\
\hline
\end{tabular}

Table S3.5: Country-level regressions of family ties on the Kinship Intensity Index, log percent cousin marriage, and Western and Eastern Church exposure. Each column contains 4 regressions, each with a different explanatory variable. Regressions in Column 2 to 9, and 11 contain the set of baseline controls (ruggedness, mean distance to waterways, caloric suitability, and absolute latitude). In addition, Column 3 controls for parasite stress and tropical area; Column 4 for irrigation potential; Column 5 for caloric suitability for rain-fed oats and rye; Column 6 for the ancestor adjusted timing of the Neolithic Transformation and the ancestor adjusted genetic heterogeneity; Column 7 for the fraction of people adhering to major religions (fraction Catholic, Protestant, Orthodox, other Christian, Muslim, Hindu, Buddhist); and Column 8 for (mean) importance placed on religion. Continent fixed effects are controlled for in Column 9. Columns 10 and 11 report the regressions based on the sub-sample that only contains countries where ancestors were exposed to an average of no more than 120 years of the medieval Churches' MFP. Robust standard errors are reported in parentheses, as well as the number of observations and $\mathrm{R}$-squared for each regression. $* P \leq 0.1, * * P \leq 0.05, * * * P \leq 0.01$ (two-sided). 


\section{Robustness Checks}

\section{i. Robustness check: Conley standard errors}

The unit of observation in Section S3 is the country. Shifting borders, as well as cultural practices and social norms which transcend contemporary borders, raise concerns that the error terms exhibit spatial autocorrelation and that trans-national (cultural) clusters confound our statistical analysis. Here we re-present estimates, this time with standard errors that have been corrected for spatial autocorrelation following the methodology of Conley (188). The autocorrelation is modeled as declining linearly away from each observation (i.e., country), as a function of the aerial distance between the country and other countries, up to a threshold of $5,000 \mathrm{~km}$ (we set this threshold following (182)).

One drawback of this approach is that it does not fully capture cultural clusters that emerged due to migration. For example, the New World falls mostly outside the $5,000 \mathrm{~km}$ radius from the Old World, yet, they have a similar cultural background. In addition to correcting for spatial autocorrelation, we corrected for autocorrelations based on genetic distance, also using the methodology of Conley (188). Genetic distance is a proxy for the timing of divergence between different societies. Spolaore and Wazcniarg (211) and Muthukrishna et al. (212) demonstrate that genetic closeness is also predictive of cultural similarity (this may be due either to a more recent common history or to cultural innovations spreading faster among genetically more related individuals). We therefore created a Euclidean plane using genetic distance between all pairs of countries in the sample. We use the population-adjusted measure of genetic distance based on Spolaore and Wazcniarg (213). The transformation of pairwise distances into the Euclidean is an approximation, which introduces some uncertainty. Autocorrelation is modeled as declining linearly away from each observation up to a threshold of $\mathrm{F}_{\mathrm{ST}}=0.0977$ of the fixation index, ${ }^{43}$ which represents the genetic distance between Russia and Germany.

In Table S3.6 we report the regressions, one for each of the dependent variables for which we reported regressions in Section S3.1. Each column controls for the baseline set of geographic controls. In addition to the robust standard errors, Conley standard errors based on aerial distance are reported in square brackets and Conley standard errors based on genetic distance are reported in curved brackets (significance stars refer to the standard specifications of robust standard errors). The table reveals that standard errors do not change much in the different specifications.

\footnotetext{
${ }^{43}$ The fixation index measures genetic distance with 0 denoting identical allele frequencies at a given locus, and 1 denoting completely different frequencies at that locus.
} 


\begin{tabular}{|c|c|c|c|c|c|c|c|c|}
\hline & \multicolumn{3}{|c|}{ Conformity \& obedience } & \multicolumn{3}{|c|}{ Individualism \& independence } & \multirow{2}{*}{$\begin{array}{c}\text { Impersonal } \\
\text { cooperation } \\
\text { Blood } \\
\text { donations } \\
(7)\end{array}$} & \\
\hline & $\begin{array}{c}\text { Obedience } \\
\text { (1) }\end{array}$ & $\begin{array}{c}\text { Tradition } \\
\text { (2) }\end{array}$ & $\begin{array}{c}\text { Proper } \\
\text { behavior } \\
(3)\end{array}$ & $\begin{array}{c}\text { Individualism } \\
\text { (4) }\end{array}$ & $\begin{array}{c}\text { No-pronoun } \\
\text { Drop } \\
(5)\end{array}$ & $\begin{array}{c}\text { Creativity } \\
\text { (6) }\end{array}$ & & \\
\hline KII & $2.66^{*}$ & $0.23^{* *}$ & 0.14 & $-3.23^{*}$ & -0.05 & $-0.37^{* * *}$ & $-3.11^{* * *}$ & \\
\hline Robust standard errors & $(1.42)$ & $(0.11)$ & $(0.12)$ & $(1.63)$ & $(0.05)$ & $(0.13)$ & $(1.09)$ & \\
\hline Conley (geodesic dist.) & {$[1.22]$} & {$[0.13]$} & {$[0.09]$} & {$[2.35]$} & {$[0.07]$} & {$[0.15]$} & {$[1.27]$} & \\
\hline Conley (genetic dist.) & $\{1.40\}$ & $\{0.16\}$ & $\{0.08\}$ & $\{2.21\}$ & $\{0.07\}$ & $\{0.17\}$ & $\{1.08\}$ & \\
\hline$N$ & 98 & 71 & 71 & 95 & 67 & 71 & 141 & \\
\hline$R^{2}$ & 0.554 & 0.065 & 0.146 & 0.524 & 0.388 & 0.165 & 0.523 & \\
\hline Log $\%$ cousin marriage & 1.67 & $0.18^{* *}$ & 0.01 & $-3.03^{*}$ & $-0.12^{* * *}$ & $-0.23^{* *}$ & $-2.06^{* *}$ & $\frac{\sigma}{0}$ \\
\hline Robust standard errors & $(1.16)$ & $(0.07)$ & $(0.08)$ & $(1.65)$ & $(0.02)$ & $(0.08)$ & $(0.91)$ & 8 \\
\hline Conley (geodesic dist.) & {$[0.78]$} & {$[0.06]$} & {$[0.06]$} & {$[1.70]$} & {$[0.02]$} & {$[0.08]$} & {$[0.65]$} & 龸. \\
\hline Conley (genetic dist.) & $\{0.91\}$ & $\{0.06\}$ & $\{0.05\}$ & $\{1.20\}$ & $\{0.03\}$ & $\{0.09\}$ & $\{0.79\}$ & 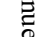 \\
\hline$N$ & 57 & 44 & 44 & 57 & 49 & 44 & 62 & 象 \\
\hline$R^{2}$ & 0.439 & 0.420 & 0.155 & 0.612 & 0.653 & 0.363 & 0.684 & $\frac{1}{6}$ \\
\hline W. Church exposure & 0.10 & $-0.16^{* * *}$ & 0.03 & $3.20^{* * *}$ & $0.07^{* * *}$ & $0.21^{* * *}$ & $2.76^{* * *}$ & $\stackrel{0}{\&}$ \\
\hline Robust standard errors & $(0.55)$ & $(0.05)$ & $(0.04)$ & $(0.71)$ & $(0.02)$ & $(0.04)$ & $(0.46)$ & \\
\hline Conley (geodesic dist.) & {$[0.60]$} & {$[0.06]$} & {$[0.04]$} & {$[0.72]$} & {$[0.02]$} & {$[0.05]$} & {$[0.52]$} & \\
\hline Conley (genetic dist.) & $\{0.64\}$ & $\{0.05\}$ & $\{0.02\}$ & $\{0.42\}$ & $\{0.02\}$ & $\{0.03\}$ & $\{0.37\}$ & \\
\hline E. Church exposure & 0.50 & 0.15 & $0.14^{* *}$ & -1.55 & -0.03 & 0.07 & 1.21 & \\
\hline Robust standard errors & $(1.14)$ & $(0.14)$ & $(0.07)$ & $(1.29)$ & $(0.02)$ & $(0.12)$ & $(1.45)$ & \\
\hline Conley (geodesic dist.) & {$[1.00]$} & {$[0.11]$} & {$[0.05]$} & {$[0.88]$} & {$[0.02]$} & {$[0.08]$} & {$[0.97]$} & \\
\hline Conley (genetic dist.) & $\{1.07\}$ & $\{0.12\}$ & $\{0.04\}$ & $\{1.12\}$ & $\{0.01\}$ & $\{0.07\}$ & $\{0.72\}$ & \\
\hline$N$ & 94 & 68 & 68 & 93 & 66 & 68 & 136 & \\
\hline$R^{2}$ & 0.548 & 0.312 & 0.185 & 0.668 & 0.523 & 0.341 & 0.667 & \\
\hline Baseline Set & Yes & Yes & Yes & Yes & Yes & Yes & Yes & \\
\hline
\end{tabular}

\begin{tabular}{|c|c|c|c|c|c|c|}
\hline & \multicolumn{2}{|c|}{ Impartiality } & \multirow{2}{*}{$\begin{array}{c}\begin{array}{c}\text { Impersonal } \\
\text { trust }\end{array} \\
\text { Out-ingroup } \\
\text { Trust } \\
(12)\end{array}$} & \multirow[b]{2}{*}{$\begin{array}{c}\text { Gen. } \\
\text { trust } \\
(13)\end{array}$} & \multirow[b]{2}{*}{$\begin{array}{c}\text { Gen. } \\
\text { fairness } \\
(14)\end{array}$} & \multirow[b]{2}{*}{$\begin{array}{c}\text { Family } \\
\text { ties } \\
(15)\end{array}$} \\
\hline & $\begin{array}{l}\text { Log parking } \\
\text { tickets } \\
\text { (9) }\end{array}$ & $\begin{array}{c}\text { Nepotism } \\
\text { (10) }\end{array}$ & & & & \\
\hline KII & $0.52^{* * *}$ & $0.15^{*}$ & $-0.40^{* * *}$ & $-0.16^{*}$ & $-0.20^{*}$ & $0.07^{* *}$ \\
\hline Robust standard errors & $(0.13)$ & $(0.09)$ & $(0.12)$ & $(0.09)$ & $(0.10)$ & $(0.03)$ \\
\hline Conley (geodesic dist.) & {$[0.10]$} & [0.15] & [0.13] & {$[0.12]$} & {$[0.13]$} & [0.03] \\
\hline Conley (genetic dist.) & $\{0.11\}$ & $\{0.15\}$ & $\{0.15\}$ & $\{0.10\}$ & $\{0.08\}$ & $\{0.03\}$ \\
\hline$N$ & 143 & 109 & 70 & 98 & 87 & 77 \\
\hline$R^{2}$ & 0.205 & 0.298 & 0.271 & 0.396 & 0.223 & 0.593 \\
\hline Log $\%$ cousin marriage & $0.31^{* *}$ & $0.23^{* * *}$ & $-0.32^{* * *}$ & -0.05 & $-0.14^{*}$ & $0.04^{*}$ \\
\hline Robust standard errors & $(0.15)$ & $(0.08)$ & $(0.11)$ & $(0.08)$ & $(0.08)$ & $(0.02)$ \\
\hline Conley (geodesic dist.) & {$[0.13]$} & {$[0.06]$} & {$[0.08]$} & {$[0.09]$} & {$[0.08]$} & {$[0.02]$} \\
\hline Conley (genetic dist.) & $\{0.13\}$ & $\{0.08\}$ & $\{0.10\}$ & $\{0.08\}$ & $\{0.07\}$ & $\{0.02\}$ \\
\hline$N$ & 64 & 55 & 44 & 57 & 51 & 45 \\
\hline$R^{2}$ & 0.146 & 0.421 & 0.403 & 0.378 & 0.299 & 0.606 \\
\hline W. Church exposure & $-0.13^{* *}$ & $-0.13^{* * *}$ & $0.18^{* * *}$ & 0.04 & 0.02 & 0.00 \\
\hline Robust standard errors & $(0.06)$ & $(0.04)$ & $(0.04)$ & $(0.04)$ & $(0.03)$ & $(0.01)$ \\
\hline Conley (geodesic dist.) & {$[0.07]$} & {$[0.04]$} & {$[0.03]$} & {$[0.04]$} & {$[0.04]$} & {$[0.01]$} \\
\hline Conley (genetic dist.) & $\{0.07\}$ & $\{0.04\}$ & $\{0.04\}$ & $\{0.05\}$ & $\{0.04\}$ & $\{0.01\}$ \\
\hline E. Church exposure & -0.01 & 0.09 & 0.02 & -0.10 & $-0.24^{* * *}$ & 0.03 \\
\hline Robust standard errors & $(0.14)$ & $(0.07)$ & $(0.06)$ & $(0.06)$ & $(0.06)$ & $(0.02)$ \\
\hline Conley (geodesic dist.) & {$[0.10]$} & {$[0.05]$} & {$[0.06]$} & {$[0.08]$} & {$[0.07]$} & {$[0.02]$} \\
\hline Conley (genetic dist.) & $\{0.09\}$ & $\{0.06\}$ & $\{0.03\}$ & $\{0.08\}$ & $\{0.07\}$ & $\{0.02\}$ \\
\hline$N$ & 138 & 105 & 67 & 94 & 83 & 74 \\
\hline$R^{2}$ & 0.149 & 0.413 & 0.364 & 0.418 & 0.319 & 0.594 \\
\hline Baseline Set & Yes & Yes & Yes & Yes & Yes & Yes \\
\hline
\end{tabular}

Table S3.6 Country-level OLS regression of the psychological measures on the Kinship Intensity Index (upper rows), log percent cousin marriages (middle rows), and Eastern and Western Church exposure (lower rows). Each column corresponds to a different dependent variable and contains the results of four regressions, each with a different explanatory variable. All regressions control for geographic baseline set of covariates (ruggedness, mean distance to waterways, caloric suitability, and absolute latitude). Robust standard errors are reported in parentheses, Conley standard errors based on geodesic distance in square brackets, and Conley standard errors based on genetic distance in curly brackets. Significance levels reported are based on robust standard errors: * $P \leq 0.1, * * P \leq 0.05, * * * P \leq 0.01$ (two-sided). 


\section{ii. Robustness check: year of data collection}

Our measure of KII rests on ethnicity-level information compiled by ethnographers, and the year in which ethnicities' characteristics were coded varies. Here we report regressions where we include the year of observation (aggregated to the country level - it is thus a population-weighted average of the underlying ethnicities in a country following the aggregation method detailed in Section S8). Similarly, the year of the $\log$ percent cousin marriage data also varies, since it is based on a meta-study. We therefore also report regressions of log percent cousin marriage that control for the year of data collection. In cases where we used more than one data source for a country, the year of data collection represents a weighted average. We present the results in Table S3.7.

\begin{tabular}{|c|c|c|c|c|c|c|c|}
\hline & \multicolumn{3}{|c|}{ Conformity \& obedience } & \multicolumn{3}{|c|}{ Individualism \& independence } & \multirow{2}{*}{$\begin{array}{c}\text { Impersonal } \\
\text { cooperation } \\
\text { Blood } \\
\text { donations } \\
\text { (7) }\end{array}$} \\
\hline & $\begin{array}{c}\text { Obedience } \\
\text { (1) }\end{array}$ & $\begin{array}{c}\text { Tradition } \\
\text { (2) }\end{array}$ & $\begin{array}{l}\text { Proper } \\
\text { behavior } \\
\text { (3) }\end{array}$ & $\begin{array}{c}\text { Individualism } \\
\text { (4) }\end{array}$ & $\begin{array}{c}\text { No-pronoun } \\
\text { Drop } \\
(5)\end{array}$ & $\begin{array}{c}\text { Creativity } \\
\text { (6) }\end{array}$ & \\
\hline KII & $\begin{array}{l}2.66^{*} \\
(1.43)\end{array}$ & $\begin{array}{l}0.23^{* *} \\
(0.11)\end{array}$ & $\begin{array}{c}0.14 \\
(0.12)\end{array}$ & $\begin{array}{l}-3.22^{*} \\
(1.65)\end{array}$ & $\begin{array}{l}-0.05 \\
(0.05)\end{array}$ & $\begin{array}{c}-0.37^{* * *} \\
(0.13)\end{array}$ & $\begin{array}{c}-3.01^{* * *} \\
(1.10)\end{array}$ \\
\hline$N$ & 98 & 71 & 71 & 95 & 67 & 71 & 140 \\
\hline$R^{2}$ & 0.554 & 0.091 & 0.178 & 0.525 & 0.415 & 0.168 & 0.539 \\
\hline Log $\%$ cousin $m$. & $\begin{array}{c}1.70 \\
(1.17)\end{array}$ & $\begin{array}{c}0.18^{*} \\
(0.10)\end{array}$ & $\begin{array}{c}0.05 \\
(0.12)\end{array}$ & $\begin{array}{l}-3.09 \\
(2.38)\end{array}$ & $\begin{array}{c}-0.15^{* * *} \\
(0.03)\end{array}$ & $\begin{array}{c}-0.32^{* * *} \\
(0.08)\end{array}$ & $\begin{array}{l}-1.72 \\
(1.15)\end{array}$ \\
\hline$N$ & 55 & 42 & 42 & 56 & 48 & 42 & 61 \\
\hline$R^{2}$ & 0.431 & 0.447 & 0.230 & 0.612 & 0.747 & 0.506 & 0.683 \\
\hline Baseline controls & Yes & Yes & Yes & Yes & Yes & Yes & Yes \\
\hline Year of data collection & Yes & Yes & Yes & Yes & Yes & Yes & Yes \\
\hline
\end{tabular}

\begin{tabular}{|c|c|c|c|c|c|c|}
\hline & \multicolumn{2}{|c|}{ Impartiality } & \multirow{2}{*}{$\begin{array}{c}\begin{array}{c}\text { Impersonal } \\
\text { trust }\end{array} \\
\text { Out-ingroup } \\
\text { trust } \\
(12)\end{array}$} & \multirow[b]{2}{*}{$\begin{array}{l}\text { Gen. } \\
\text { Trust } \\
(13)\end{array}$} & \multirow[b]{2}{*}{$\begin{array}{l}\text { Gen. } \\
\text { Fair } \\
(14)\end{array}$} & \multirow[b]{2}{*}{$\begin{array}{c}\text { Family } \\
\text { ties } \\
(15)\end{array}$} \\
\hline & $\begin{array}{l}\text { Log parking } \\
\text { tickets } \\
\text { (9) }\end{array}$ & $\begin{array}{c}\text { Nepotism } \\
\text { (10) }\end{array}$ & & & & \\
\hline KII & $0.53^{* * *}$ & 0.15 & $-0.41^{* * *}$ & $-0.16^{*}$ & $-0.20^{* *}$ & $0.07^{* *}$ \\
\hline & $(0.13)$ & $(0.09)$ & $(0.12)$ & $(0.09)$ & $(0.10)$ & $(0.03)$ \\
\hline$N$ & 143 & 109 & 70 & 98 & 87 & 77 \\
\hline$R^{2}$ & 0.206 & 0.300 & 0.271 & 0.413 & 0.238 & 0.594 \\
\hline Log $\%$ cousin $m$. & $0.42^{* *}$ & $0.23^{* *}$ & $-0.35^{* * *}$ & -0.08 & -0.11 & $0.04^{*}$ \\
\hline & $(0.17)$ & $(0.09)$ & $(0.10)$ & $(0.09)$ & $(0.09)$ & $(0.02)$ \\
\hline$N$ & 62 & 54 & 42 & 55 & 49 & 44 \\
\hline$R^{2}$ & 0.158 & 0.426 & 0.424 & 0.412 & 0.307 & 0.594 \\
\hline Baseline controls & Yes & Yes & Yes & Yes & Yes & Yes \\
\hline Year of observation & Yes & Yes & Yes & Yes & Yes & Yes \\
\hline
\end{tabular}

Table S3.7: Country-level OLS regressions of the psychological and behavioral measures on the Kinship Intensity Index (upper rows), and $\log$ percent cousin marriage (lower rows). Each column corresponds to a different dependent variable and contains the results of two regressions, each with a different explanatory variable. All columns contain the baseline set of geographic covariates (ruggedness, mean distance to waterways, caloric suitability, and absolute latitude) as well as a control variable capturing the year of data collection for the explanatory variable. Robust standard errors are reported in parentheses. * $P \leq 0.1,{ }^{* *} P \leq 0.05, * * * \mathrm{P} \leq 0.01$ (two-sided).

\section{iii. Robustness check: GDP}

One might wonder whether GDP per capita potentially confounds our analysis. This is unlikely. First, our strategy was to use explanatory variables that are unaffected by today's GDP: the KII is based on EA data that are meant to reflect the state of affairs prior to industrialization; this rules out the possibility that today's GDP affected the KII. The same is the case for Church exposure.

Second, all sub-sequent analyses (Sections S4, S5, S6 and S7) show that the association between kinship intensity and psychology is significant in analyses that rely on within-country variation; given that there is 
much less variation in GDP per capita within countries, this suggests that current GDP per capita is not the key causal link between kinship intensity and psychology. Particularly strong evidence comes from the children of immigrants analysis, which exploits the variation of the cultural background of individuals who all grew up in the same country.

Simply adding GDP per capita as a control variable is problematic, since GDP per capita is likely to be endogenous to kinship intensity. Indeed, it is likely that higher kinship intensity has a negative causal impact on GDP per capita. Many researchers have pointed out that trust is essential for economic prosperity (214216), and our study reports a negative association between kinship intensity and (out-group) trust. Moreover, moving away from a kin-based economy allows society to capture gains from comparative advantage and fostering the formation of inclusive institutions. In our ongoing work, we find empirical evidence that intensive kinship, as proxied by genetic measures that are highly correlated with cousin marriages, indeed impacts economic prosperity. Kinship intensity fosters corruption (Akbari et al. (217)), hinders the development of large-scale, well-functioning institutions (Schulz (98), Woodley and Bell (218)), and - as we report here - decreases outgroup trust (which is an important prerequisite for trade and the division of labor). Other plausible channels include the possibility that kinship intensity distorts creativity (see Table S3.2 above) and entrepreneurial incentives (as profits need to be shared with the kin-group) and hampers the diffusion of technology (219). Thus, GDP is most likely - at least partially - determined by kinship intensity. Controlling for GDP per capita in our regressions therefore most likely decreases the coefficient of kinship intensity as GDP is an outcome of kinship intensity.

For completeness, in Table S3.8 we report the results of regression specifications that control for GDP per capita. For each of our dependent and explanatory variables, the table reports results from the regressions with and without the set of geographic baseline controls. While the coefficients mostly have the expected signs, they are not as consistently significant as in most other previous specifications. Given that GPD per capita is most likely highly endogenous, this is not surprising. Yet, even when controlling for the baseline set of geographic covariates the KII is a statistically significant predictor of log unpaid parking tickets per diplomat and out-ingroup trust. 


\begin{tabular}{|c|c|c|c|c|c|c|c|c|c|c|c|c|c|c|}
\hline & \multicolumn{6}{|c|}{$\begin{array}{c}\text { Conformity \& } \\
\text { obedience }\end{array}$} & \multicolumn{6}{|c|}{$\begin{array}{l}\text { Individualism \& } \\
\text { Independence }\end{array}$} & \multirow{2}{*}{\multicolumn{2}{|c|}{$\begin{array}{c}\begin{array}{c}\text { Impersonal } \\
\text { cooperation }\end{array} \\
\begin{array}{c}\text { Blood } \\
\text { donation }\end{array} \\
\end{array}$}} \\
\hline & \multicolumn{2}{|c|}{ Obedience } & \multicolumn{2}{|c|}{ Tradition } & \multicolumn{2}{|c|}{$\begin{array}{c}\text { Proper } \\
\text { behavior }\end{array}$} & \multicolumn{2}{|c|}{$\begin{array}{c}\text { Indi- } \\
\text { vidualism }\end{array}$} & \multicolumn{2}{|c|}{$\begin{array}{l}\text { No-pronoun } \\
\text { Drop } \\
\end{array}$} & \multicolumn{2}{|c|}{ Creativity } & & \\
\hline & (1) & (2) & (3) & (4) & (5) & (6) & (7) & (8) & (9) & (10) & (11) & (12) & (13) & (14) \\
\hline KII & $\begin{array}{c}2.64 \\
(2.02)\end{array}$ & $\begin{array}{c}1.36 \\
(1.62)\end{array}$ & $\begin{array}{c}0.11 \\
(0.11)\end{array}$ & $\begin{array}{c}0.04 \\
(0.12)\end{array}$ & $\begin{array}{c}0.01 \\
(0.14)\end{array}$ & $\begin{array}{c}0.19 \\
(0.13)\end{array}$ & $\begin{array}{l}-1.32 \\
(2.25)\end{array}$ & $\begin{array}{l}-1.31 \\
(1.81)\end{array}$ & $\begin{array}{l}-0.02 \\
(0.06)\end{array}$ & $\begin{array}{l}-0.06 \\
(0.05)\end{array}$ & $\begin{array}{l}-0.35^{* *} \\
(0.13)\end{array}$ & $\begin{array}{l}-0.33^{* *} \\
(0.14)\end{array}$ & $\begin{array}{l}-2.11^{*} \\
(1.23)\end{array}$ & $\begin{array}{l}-0.62 \\
(1.12)\end{array}$ \\
\hline$N$ & 98 & 98 & 71 & 71 & 71 & 71 & 95 & 95 & 67 & 67 & 71 & 71 & 140 & 140 \\
\hline$R^{2}$ & 0.293 & 0.570 & 0.083 & 0.179 & 0.020 & 0.153 & 0.378 & 0.545 & 0.197 & 0.390 & 0.157 & 0.171 & 0.561 & 0.638 \\
\hline $\log \%$ cousin $m$. & $\begin{array}{l}2.31^{*} \\
(1.17)\end{array}$ & $\begin{array}{c}0.79 \\
(1.11)\end{array}$ & $\begin{array}{l}0.24^{* * *} \\
(0.07)\end{array}$ & $\begin{array}{l}0.15^{* *} \\
(0.07)\end{array}$ & $\begin{array}{l}-0.02 \\
(0.08)\end{array}$ & $\begin{array}{c}0.02 \\
(0.09)\end{array}$ & $\begin{array}{l}-3.36^{* *} \\
(1.49)\end{array}$ & $\begin{array}{l}-1.47 \\
(1.56)\end{array}$ & $\begin{array}{c}-0.15^{* * *} \\
(0.03)\end{array}$ & $\begin{array}{l}-0.13^{* * *} \\
(0.03)\end{array}$ & $\begin{array}{l}-0.31^{* * *} \\
(0.08)\end{array}$ & $\begin{array}{l}-0.24^{* *} \\
(0.09)\end{array}$ & $\begin{array}{l}-3.26^{* * *} \\
(0.89)\end{array}$ & $\begin{array}{l}-0.99 \\
(0.88)\end{array}$ \\
\hline $\begin{array}{l}N \\
R^{2}\end{array}$ & $\begin{array}{c}57 \\
0303\end{array}$ & 57 & 44 & 44 & 44 & 44 & 57 & 57 & 49 & 49 & 44 & 44 & 62 & 62 \\
\hline$R^{2}$ & 0.303 & 0.483 & 0.322 & 0.427 & 0.020 & 0.156 & 0.451 & 0.656 & 0.417 & 0.665 & 0.300 & 0.366 & 0.569 & 0.736 \\
\hline W. Church exposure & $\begin{array}{l}-0.47 \\
(0.76)\end{array}$ & $\begin{array}{l}1.19^{* *} \\
(0.60)\end{array}$ & $\begin{array}{l}-0.11^{* *} \\
(0.05)\end{array}$ & $\begin{array}{l}-0.11^{*} \\
(0.05)\end{array}$ & $\begin{array}{c}0.03 \\
(0.05)\end{array}$ & $\begin{array}{c}0.02 \\
(0.05)\end{array}$ & $\begin{array}{l}4.10^{* * *} \\
(0.66)\end{array}$ & $\begin{array}{l}3.17^{* * *} \\
(0.78)\end{array}$ & $\begin{array}{l}0.09^{* * *} \\
(0.02)\end{array}$ & $\begin{array}{l}0.08^{* * *} \\
(0.02)\end{array}$ & $\begin{array}{l}0.23^{* * *} \\
(0.04)\end{array}$ & $\begin{array}{l}0.23^{* * *} \\
(0.04)\end{array}$ & $\begin{array}{l}2.74^{* * *} \\
(0.46)\end{array}$ & $\begin{array}{l}1.86^{* * *} \\
(0.50)\end{array}$ \\
\hline E. Church exposure & $\begin{array}{l}-2.57^{* *} \\
(1.07)\end{array}$ & $\begin{array}{l}1.10 \\
(1.02)\end{array}$ & $\begin{array}{c}0.17 \\
(0.11)\end{array}$ & $\begin{array}{c}0.19 \\
(0.13)\end{array}$ & $\begin{array}{l}0.14^{* *} \\
(0.06)\end{array}$ & $\begin{array}{l}0.14^{*} \\
(0.08)\end{array}$ & $\begin{array}{c}0.43 \\
(0.65)\end{array}$ & $\begin{array}{l}-1.57 \\
(1.31)\end{array}$ & $\begin{array}{l}-0.02 \\
(0.01)\end{array}$ & $\begin{array}{l}-0.01 \\
(0.02)\end{array}$ & $\begin{array}{c}0.08 \\
(0.12)\end{array}$ & $\begin{array}{c}0.08 \\
(0.12)\end{array}$ & $\begin{array}{l}1.84^{*} \\
(0.99)\end{array}$ & $\begin{array}{c}0.44 \\
(1.36)\end{array}$ \\
\hline$N$ & 94 & 94 & 68 & 68 & 68 & 68 & 93 & 93 & 66 & 66 & 68 & 68 & 135 & 135 \\
\hline$R^{2}$ & 0.365 & 0.605 & 0.224 & 0.353 & 0.051 & 0.185 & 0.537 & 0.668 & 0.431 & 0.541 & 0.294 & 0.344 & 0.655 & 0.705 \\
\hline $\begin{array}{l}\text { Geographic base. } \\
\text { Log GDP per capita }\end{array}$ & $\begin{array}{c}- \\
\text { Yes } \\
\end{array}$ & $\begin{array}{l}\text { Yes } \\
\text { Yes }\end{array}$ & $\begin{array}{c}- \\
\text { Yes } \\
\end{array}$ & $\begin{array}{l}\text { Yes } \\
\text { Yes }\end{array}$ & $\begin{array}{c}- \\
\text { Yes }\end{array}$ & $\begin{array}{l}\text { Yes } \\
\text { Yes } \\
\end{array}$ & $\begin{array}{c}- \\
\text { Yes }\end{array}$ & $\begin{array}{l}\text { Yes } \\
\text { Yes } \\
\end{array}$ & $\begin{array}{c}- \\
\text { Yes } \\
\end{array}$ & $\begin{array}{l}\text { Yes } \\
\text { Yes } \\
\end{array}$ & $\begin{array}{c}- \\
\text { Yes }\end{array}$ & $\begin{array}{l}\text { Yes } \\
\text { Yes } \\
\end{array}$ & $\begin{array}{c}- \\
\text { Yes } \\
\end{array}$ & $\begin{array}{l}\text { Yes } \\
\text { Yes }\end{array}$ \\
\hline
\end{tabular}

\begin{tabular}{|c|c|c|c|c|c|c|c|c|c|c|c|c|}
\hline & \multicolumn{4}{|c|}{ Impartiality } & \multirow{2}{*}{\multicolumn{2}{|c|}{$\begin{array}{c}\text { Impersonal trust } \\
\text { Out-ingroup } \\
\text { Trust }\end{array}$}} & \multirow{2}{*}{\multicolumn{2}{|c|}{ Gen. trust }} & \multirow{2}{*}{\multicolumn{2}{|c|}{ Gen. fairness }} & \multirow{2}{*}{\multicolumn{2}{|c|}{ Family ties }} \\
\hline & \multicolumn{2}{|c|}{$\begin{array}{l}\text { Log parking } \\
\text { tickets }\end{array}$} & \multicolumn{2}{|c|}{ Nepotism } & & & & & & & & \\
\hline & $(15)$ & $(16)$ & $(17)$ & (18) & (19) & (20) & (21) & (22) & (23) & (24) & (25) & (26) \\
\hline KII & $0.38^{* * * *}$ & $0.39^{* * *}$ & -0.02 & -0.01 & $-0.40^{* * * *}$ & $-0.32^{* *}$ & 0.03 & -0.14 & 0.07 & -0.13 & 0.03 & 0.05 \\
\hline & $(0.13)$ & $(0.14)$ & $(0.08)$ & $(0.09)$ & $(0.13)$ & $(0.13)$ & $(0.12)$ & $(0.11)$ & $(0.13)$ & $(0.13)$ & $(0.05)$ & $(0.03)$ \\
\hline$N$ & 143 & 143 & 109 & 109 & 70 & 70 & 98 & 98 & 87 & 87 & 77 & 77 \\
\hline$R^{2}$ & 0.253 & 0.257 & 0.399 & 0.431 & 0.248 & 0.293 & 0.197 & 0.397 & 0.060 & 0.233 & 0.317 & 0.598 \\
\hline Log $\%$ cousin $m$. & 0.18 & 0.20 & $0.13^{* *}$ & $0.15^{*}$ & $-0.32^{* * *}$ & $-0.25^{* *}$ & -0.01 & -0.05 & 0.04 & -0.09 & $0.07^{* *}$ & 0.04 \\
\hline & $(0.13)$ & $(0.15)$ & $(0.06)$ & $(0.08)$ & $(0.09)$ & $(0.11)$ & $(0.08)$ & $(0.09)$ & $(0.08)$ & $(0.09)$ & $(0.03)$ & $(0.03)$ \\
\hline$N$ & 64 & 64 & 55 & 55 & 44 & 44 & 57 & 57 & 51 & 51 & 45 & 45 \\
\hline$R^{2}$ & 0.201 & 0.220 & 0.514 & 0.555 & 0.389 & 0.427 & 0.120 & 0.378 & 0.084 & 0.333 & 0.398 & 0.606 \\
\hline W. Church exposure & -0.06 & -0.05 & -0.06 & -0.06 & $0.19^{* * *}$ & $0.16^{* * *}$ & 0.03 & 0.03 & -0.03 & -0.01 & 0.00 & 0.02 \\
\hline & $(0.06)$ & $(0.06)$ & $(0.04)$ & $(0.04)$ & $(0.04)$ & $(0.04)$ & $(0.04)$ & $(0.04)$ & $(0.04)$ & $(0.04)$ & $(0.02)$ & $(0.01)$ \\
\hline E. Church exposure & 0.01 & 0.05 & $0.15^{* * *}$ & $0.14^{* *}$ & 0.05 & 0.00 & $-0.08^{*}$ & $-0.11^{*}$ & $-0.29^{* * * *}$ & $-0.25^{* * *}$ & -0.00 & $0.04^{*}$ \\
\hline & $(0.13)$ & $(0.13)$ & $(0.05)$ & $(0.06)$ & $(0.07)$ & $(0.07)$ & $(0.05)$ & $(0.06)$ & $(0.04)$ & $(0.06)$ & $(0.02)$ & $(0.02)$ \\
\hline$N$ & 138 & 138 & 105 & 105 & 67 & 67 & 94 & 94 & 83 & 83 & 74 & 74 \\
\hline$R^{2}$ & 0.200 & 0.209 & 0.464 & 0.479 & 0.299 & 0.370 & 0.221 & 0.419 & 0.219 & 0.329 & 0.301 & 0.611 \\
\hline Geographic base. & - & Yes & - & Yes & - & Yes & - & Yes & - & Yes & - & Yes \\
\hline GDP per capita & Yes & Yes & Yes & Yes & Yes & Yes & Yes & Yes & Yes & Yes & Yes & Yes \\
\hline
\end{tabular}

Table S3.8 Country-level OLS regressions of the psychological and behavioral measures on the Kinship Intensity Index (upper rows), log percent cousin marriages (middle rows), and Eastern and Western Church exposure (lower rows). Each column corresponds to a different dependent variable and contains the results of 4 regressions, each with a different explanatory variable. All regressions control for the log GDP per capita (in 2000 dollars). Even-numbered columns also contain the baseline set of geographic covariates (ruggedness, mean distance to waterways, caloric suitability, and absolute latitude). Robust standard errors are reported in parentheses, as well as the number of observations $(N)$ and the R-squared for each regression. $*$ $P \leq 0.1,{ }^{*} P \leq 0.05,{ }^{* * *} \mathrm{P} \leq 0.01$ (two-sided). 


\section{iv. Robustness check: Polygyny}

Our KII consists of five sub-indicators. One of the sub-indicators is polygamy (almost exclusively capturing polygyny). Walker and Bailey (23) propose that polygynous marriage increases kinship intensity. The reasoning is that it creates a larger share of half-siblings in society who are genetically more related to each other compared to societies where this share is lower. Moreover, those half siblings most often co-reside when growing up. Clearly polygynous marriages, which create marital ties between only one men with multiple women, reduces the number of possible marital ties compared to societies where monogamous marriages prevail. The higher share of unmarried men in polygynous societies do not form marital ties with women and their families. However, some have suggested that by creating a higher share of unmarried men, polygynous marriage may not increase kinship intensity. The issue is: do unmarried men, who are not tied into society by marriage, reach out to form new ties or do they simply nourish their existing ties through families, some of whom may be married polygynously? Lastly, polygynous marriages may affect psychology through channels other than kinship intensity. For instance, when a large share of society's male population is unmarried due to lack of marriable women, this may also influence psychology, e.g. by engaging in more risky and violent behavior to increase chances of finding a marriage partner (6).

When we created the KII, we followed Walker and Bailey and used polygamous marriages as one subindicator for kinship intensity. Here, to address the concern about the role of polygynous marriage, we recreate the KII excluding polygamous marriages. This indicator is only based on (i) cousin marriage preference, (ii) co-residence of extended families, (iii) lineage organization, and (iv) communal organization. Table S3.9 reports the regression results for all dependent variables on the KII without polygamy. All regressions control for the geographic baseline controls. In addition, all even numbered columns control for the sub-indicator polygamy. This demonstrates that the results hold with the KII when polygamy is excluded. The coefficients for the KII without polygamy tends to increase in most specifications when controlling for polygamy (all even numbered columns). This is evidence of a more ambiguous role of polygamy. However, caution is necessary when interpreting the results: KII without polygamy and the sub-indicator polygamy are highly correlated (Pearson's correlation of 0.72 ), which may give rise to multicollinearity. 


\begin{tabular}{|c|c|c|c|c|c|c|c|c|c|c|c|c|}
\hline & \multicolumn{6}{|c|}{$\begin{array}{c}\text { Conformity \& } \\
\text { obedience }\end{array}$} & \multicolumn{6}{|c|}{$\begin{array}{c}\text { Individualism \& } \\
\text { Independence }\end{array}$} \\
\hline & \multicolumn{2}{|c|}{ Obedience } & \multicolumn{2}{|c|}{ Tradition } & \multicolumn{2}{|c|}{$\begin{array}{c}\text { Proper } \\
\text { behavior }\end{array}$} & \multicolumn{2}{|c|}{$\begin{array}{c}\text { Indi- } \\
\text { vidualism }\end{array}$} & \multicolumn{2}{|c|}{$\begin{array}{c}\text { No-pronoun } \\
\text { Drop }\end{array}$} & \multicolumn{2}{|c|}{ Creativity } \\
\hline & (1) & (2) & (3) & (4) & (5) & (6) & (7) & (8) & (9) & (10) & (11) & (12) \\
\hline KII w/o pol. & $\begin{array}{c}1.95 \\
(1.34)\end{array}$ & $\begin{array}{l}-2.44 \\
(1.77)\end{array}$ & $\begin{array}{l}0.24^{* *} \\
(0.11)\end{array}$ & $\begin{array}{c}0.33^{*} \\
(0.20)\end{array}$ & $\begin{array}{c}0.13 \\
(0.12)\end{array}$ & $\begin{array}{c}0.12 \\
(0.21)\end{array}$ & $\begin{array}{l}-3.56^{* *} \\
(1.59)\end{array}$ & $\begin{array}{l}-6.41^{* *} \\
(2.49)\end{array}$ & $\begin{array}{l}-0.06 \\
(0.05)\end{array}$ & $\begin{array}{l}-0.18^{* *} \\
(0.07)\end{array}$ & $\begin{array}{c}-0.39^{* * * *} \\
(0.12)\end{array}$ & $\begin{array}{c}-0.57^{* * *} \\
(0.18)\end{array}$ \\
\hline Polygamy & & $\begin{array}{l}8.19^{* * *} \\
(2.00)\end{array}$ & & $\begin{array}{l}-0.18 \\
(0.25)\end{array}$ & & $\begin{array}{c}0.02 \\
(0.24)\end{array}$ & & $\begin{array}{c}4.80 \\
(3.23)\end{array}$ & & $\begin{array}{l}0.21^{*} \\
(0.11)\end{array}$ & & $\begin{array}{c}0.34 \\
(0.22)\end{array}$ \\
\hline$N$ & 98 & 98 & 71 & 71 & 71 & 71 & 95 & 95 & 67 & 67 & 71 & 71 \\
\hline$R^{2}$ & 0.547 & 0.599 & 0.071 & 0.078 & 0.146 & 0.146 & 0.529 & 0.542 & 0.393 & 0.427 & 0.182 & 0.208 \\
\hline $\begin{array}{l}\text { Geographic } \\
\text { baseline }\end{array}$ & Yes & Yes & Yes & Yes & Yes & Yes & Yes & Yes & Yes & Yes & Yes & Yes \\
\hline
\end{tabular}

\begin{tabular}{|c|c|c|c|c|c|c|c|c|c|c|c|c|c|c|}
\hline & \multicolumn{4}{|c|}{ Impersonal cooperation and trust } & \multirow{2}{*}{\multicolumn{2}{|c|}{ Gen. trust }} & \multirow{2}{*}{\multicolumn{2}{|c|}{ Gen. fairness }} & \multicolumn{4}{|c|}{ Impartiality } & \multirow{2}{*}{\multicolumn{2}{|c|}{ Family ties }} \\
\hline & \multicolumn{2}{|c|}{$\begin{array}{c}\text { Blood } \\
\text { donation }\end{array}$} & \multicolumn{2}{|c|}{$\begin{array}{c}\text { Out-ingroup } \\
\text { Trust }\end{array}$} & & & & & $\begin{array}{r}\log p \\
\text { tic }\end{array}$ & $\begin{array}{l}\text { Irking } \\
\text { ets }\end{array}$ & & tism & & \\
\hline & (13) & (14) & (15) & (16) & (17) & (18) & (19) & (20) & (21) & (22) & (23) & (24) & (25) & (26) \\
\hline KII w/o pol. & $\begin{array}{c}-3.10^{* * *} \\
(1.13)\end{array}$ & $\begin{array}{l}-2.79 \\
(1.75)\end{array}$ & $\begin{array}{c}-0.40^{* * *} \\
(0.12)\end{array}$ & $\begin{array}{c}-0.49^{* * *} \\
(0.18)\end{array}$ & $\begin{array}{l}-0.17^{*} \\
(0.09)\end{array}$ & $\begin{array}{l}-0.27^{* *} \\
(0.14)\end{array}$ & $\begin{array}{c}-0.21^{* *} \\
(0.10)\end{array}$ & $\begin{array}{l}-0.35^{* *} \\
(0.15)\end{array}$ & $\begin{array}{l}0.51^{* * *} \\
(0.13)\end{array}$ & $\begin{array}{l}0.45^{* * *} \\
(0.16)\end{array}$ & $\begin{array}{l}0.19^{* *} \\
(0.08)\end{array}$ & $\begin{array}{l}0.47^{* * *} \\
(0.11)\end{array}$ & $\begin{array}{l}0.07^{* *} \\
(0.03)\end{array}$ & $\begin{array}{r}0.06 \\
(0.04)\end{array}$ \\
\hline Polygamy & & $\begin{array}{l}-0.50 \\
(1.70)\end{array}$ & & $\begin{array}{c}0.16 \\
(0.22)\end{array}$ & & $\begin{array}{c}0.20 \\
(0.20)\end{array}$ & & $\begin{array}{c}0.26 \\
(0.23)\end{array}$ & & $\begin{array}{c}0.09 \\
(0.19)\end{array}$ & & $\begin{array}{c}-0.46^{* * *} \\
(0.15)\end{array}$ & & $\begin{array}{c}0.02 \\
(0.05)\end{array}$ \\
\hline$N$ & 140 & 140 & 70 & 70 & 98 & 98 & 87 & 87 & 143 & 143 & 109 & 109 & 77 & 77 \\
\hline$R^{2}$ & 0.523 & 0.524 & 0.282 & 0.287 & 0.400 & 0.409 & 0.231 & 0.247 & 0.204 & 0.205 & 0.311 & 0.370 & 0.592 & 0.593 \\
\hline $\begin{array}{l}\text { Geographic } \\
\text { baseline }\end{array}$ & Yes & Yes & Yes & Yes & Yes & Yes & Yes & Yes & Yes & Yes & Yes & Yes & Yes & Yes \\
\hline
\end{tabular}

Table S3.9 Country-level OLS regressions of the psychological and behavioral measures on the Kinship Intensity Index without polygamy. In the even-numbered columns, we also include a control for polygamy in addition to the KII without polygamy. All columns contain the baseline set of geographic covariates (ruggedness, mean distance to waterways, caloric suitability, and absolute latitude). Robust standard errors are reported in parentheses, as well as the number of observations and R-squared for each regression. * $P \leq 0.1, * * P \leq 0.05, * * * \mathrm{P} \leq 0.01$ (two-sided) 


\section{S3.2. Medieval Church exposure and kinship intensity}

In the previous section (Section S3.1), we established an association between kinship intensity and psychological and behavioral measures. In addition, we established a reduced-form association between medieval Church exposure and these psychological measures. Here we investigate the relationship between Church exposure and our two measures of kinship intensity.

Table S3.10 reports the results from regressions of the KII (Panel 1) and the log percent cousin marriage (Panel 2) on Eastern and Western Church exposure. The covariates are identical to those used in the main analyses from Section S3.1. The results paint a coherent picture. An additional 100 years of Western Church exposure reduces the KII by about 0.24 standard deviations (Column 1). While the coefficients for Eastern Church exposure are mostly smaller, F-tests reveal that they are not significantly different from the coefficients for the Western Church. Column 1 also reveals that an additional 100 years of Western Church exposure is associated with a decrease in cousin marriages by about $38 \%(\approx(\exp (-0.48)-1) * 100)$. Eastern Church exposure is not associated with frequency of cousin marriages, but this is likely due to the fact that Bittles' country-level cousin marriage data have a poor coverage of predominantly Orthodox countries.

One drawback of the KII is that the Ethnographic Atlas (from which the KII is computed) contains only a few ethnicities in Europe. As described in Section S1 and S8, for the cross-country analyses we used EA data from ethnicities with similar languages to interpolate the KII sub-indicators when EA data were missing for an ethnicity. The KII is therefore not well-suited to examine within-Europe variation, which is where the bulk of the variation in Church exposure resides. Therefore, some caution when interpreting the country-level results is warranted. The relationship between medieval Church exposure and cousin marriages is strengthened in the subsequent (European) regional analysis (see Section 4.4). There, we exploit regional variation within Europe to demonstrate that there is a similar association between Church exposure and kinship intensity (as proxied by cousin marriages). Moreover, Korotayev (220), demonstrates that all ethnicities that experienced "deep-Christianization" (i.e. were Christianized before the year 1500) are characterized by an absence of lineages. Similarly, following Korotayev's coding of "deep-Christianization" (and extending it to the added D-PLACE ethnicities lacking a coding based on Korotayev's original article) we find a highly significant difference in the KII between those ethnicities that experienced "deepChristianization" $(\mathrm{M}=-1.57, \mathrm{SD}=0.12, \mathrm{~N}=38)$ and those that did not $(\mathrm{M}=0.06, \mathrm{SD}=0.03, \mathrm{~N}=939)$; $(\mathrm{t}(975)=10.4, \mathrm{P}<0.0001)$. 


\begin{tabular}{|c|c|c|c|c|c|c|c|c|c|}
\hline & (1) & (2) & (3) & (4) & (5) & (6) & (7) & $(8)$ & (9) \\
\hline & \multicolumn{9}{|c|}{ Panel 1: KII } \\
\hline W. Church exposure & $-0.24^{* * *}$ & $-0.21^{* * *}$ & $-0.20^{* * *}$ & $-0.18^{* * *}$ & $-0.22^{* * *}$ & $-0.19^{* * *}$ & $-0.10^{* * *}$ & $-0.15^{* * *}$ & $-0.09^{* *}$ \\
\hline (in 100 yrs.) & $(0.02)$ & $(0.03)$ & $(0.03)$ & $(0.03)$ & $(0.03)$ & $(0.02)$ & $(0.03)$ & $(0.03)$ & $(0.04)$ \\
\hline E. Church exposure & $-0.21^{* * *}$ & $-0.16^{* * *}$ & $-0.17^{* * *}$ & $-0.16^{* * *}$ & $-0.19^{* * *}$ & $-0.22^{* * *}$ & $0.10^{*}$ & $-0.14^{* *}$ & -0.01 \\
\hline (in 100 yrs.) & $(0.05)$ & $(0.06)$ & $(0.06)$ & $(0.05)$ & $(0.06)$ & $(0.05)$ & $(0.06)$ & $(0.06)$ & $(0.07)$ \\
\hline$N$ & 146 & 146 & 146 & 146 & 146 & 146 & 146 & 91 & 146 \\
\hline \multirow[t]{2}{*}{$R^{2}$} & 0.402 & 0.434 & 0.502 & 0.478 & 0.447 & 0.670 & 0.695 & 0.478 & 0.636 \\
\hline & \multicolumn{9}{|c|}{ Panel 2: Log $\%$ cousin marriage } \\
\hline W. Church exposure & $-0.48^{* * *}$ & $-0.39^{* * *}$ & $-0.38^{* * *}$ & $-0.36^{* * *}$ & $-0.41^{* * *}$ & $-0.32^{* * *}$ & -0.05 & $-0.28^{* * *}$ & -0.06 \\
\hline (in $100 \mathrm{yrs}$.) & $(0.05)$ & $(0.07)$ & $(0.07)$ & $(0.07)$ & $(0.07)$ & $(0.06)$ & $(0.06)$ & $(0.07)$ & $(0.09)$ \\
\hline E. Church exposure & 1.95 & 1.40 & 1.78 & 0.88 & 1.76 & -0.96 & 0.17 & 0.83 & 2.18 \\
\hline (in 100 yrs.) & $(1.34)$ & (1.97) & $(1.86)$ & $(2.16)$ & $(1.82)$ & $(1.61)$ & $(1.63)$ & $(1.76)$ & $(2.35)$ \\
\hline$N$ & 69 & 69 & 69 & 69 & 69 & 69 & 69 & 55 & 69 \\
\hline$R^{2}$ & 0.619 & 0.705 & 0.706 & 0.729 & 0.732 & 0.794 & 0.868 & 0.744 & 0.793 \\
\hline Baseline Controls & - & Yes & Yes & Yes & Yes & Yes & Yes & Yes & Yes \\
\hline Parasite stress \& tropical climate & - & - & Yes & - & - & - & - & - & - \\
\hline Irrigation & - & - & - & Yes & - & - & - & - & - \\
\hline Oats and rye & - & - & - & - & Yes & - & - & - & - \\
\hline $\begin{array}{l}\text { Aa. Timing of Neolithic Transf./ } \\
\text { Aa. genetic heterogeneity }\end{array}$ & - & - & - & - & - & Yes & - & - & - \\
\hline Major religions & - & - & - & - & - & - & Yes & - & - \\
\hline Religiousness & - & - & - & - & - & - & - & Yes & - \\
\hline Continent FE & - & - & - & - & - & - & - & - & Yes \\
\hline
\end{tabular}

Table S3.10 Country-level regressions of the Kinship Intensity Index (Panel 1) and log percent cousin marriage (Panel 2) on Western and Eastern Church exposure. Each column contains 2 regressions, each with a different dependent variable. Regressions in Columns 29 contain the set of baseline controls (ruggedness, mean distance to waterways, caloric suitability, absolute latitude). In addition, Column 3 controls for parasite stress and tropical climate; Column 4 for irrigation potential; Column 5 for caloric suitability for nonirrigated oats and rye; Column 6 for the ancestor adjusted timing of the Neolithic Transformation and the ancestor adjusted genetic heterogeneity; Column 7 for the fraction of people adhering to major religions (fraction Catholic, Protestant, Orthodox, other Christian, Muslim, Hindu, Buddhist); Column 8 for (mean) importance placed on religion; and Column 9 includes continent fixed effects. Robust standard errors are reported in parentheses. * $P \leq 0.1, * * P \leq 0.05, * * * \mathrm{P} \leq 0.01$ (two-sided). 


\section{S4. European Regions}

This section exploits regional variation in medieval Western Church exposure (see Section S2) and kinship intensity (proxied by cousin marriages - see Section S1) in Europe. The dependent psychological measures are based on the European Social Survey (ESS): generalized trust, generalized fairness, conformityobedience, and individualism-independence (see below for details), which cover all three domains along which we organized the cross-country results (conformity \& obedience, individualism \& independence, impersonal prosociality). In Section S7 we report evidence that within European the generalized trust question measures impersonal trust (that is, trust in strangers) as intended.

The analysis starts by demonstrating a robust reduced-form association between regional Western Church exposure and the ESS-based psychological measures (Section S4.1). Strengthening the argument about the decisiveness of the Church marriage regulations (as opposed to some other Church feature), we demonstrate that the area of the Carolingian Empire - a leader in implementing and enforcing the Western Church's MFP - is a strong predictor for the psychological measures (Section S4.2). This is consistent with historic accounts (51), which emphasizes the prevalence and heightened enforcement of the ban in this area.

Strengthening the hypothesis that the Medieval Church influenced psychological outcomes through the dissolution of kin-networks, in Section S4.3 we demonstrate a direct link between kinship intensity (proxied by cousin marriages) and the ESS-based psychological measures in regions of four countries where we have data on cousin marriages (Spain, Italy, France and Turkey). Lastly, in Section S4.4 we look at the association between Church and Carolingian exposure with cousin marriages.

Compared to the cross-country analysis, our empirical strategy in this section strengthens our main hypothesis in several ways:

(i) The analysis rests on within-country regional variation by including country fixed effects. This allows us to rule out omitted variable bias due to country-level factors like differences in the national social security systems, infrastructures or the quality of the rule of law. It also allows us to control for the effects of language, culture, and social norms that are shared at the country level.

(ii) Focusing on variation within Europe allows to demonstrate that the cross-country findings are not simply due to a more general (possibly omitted) European trait. Rather, the same associations hold within Europe as well. The analysis thus strengthens the hypothesis that the Church's MFP impacted human psychology through its effect on kinship intensity. ${ }^{44}$

(iii) The analysis uses individual-level responses, which allow us to control for individual characteristics. This is particularly relevant for religious denomination. At the cross-country level, denomination and

\footnotetext{
${ }^{44}$ At the same time, we provide evidence that the association between kinship intensity and several psychological traits also exists when excluding countries with European ancestry - see the children of immigrant analysis in Section S6 and the cross-country regression in Section S3. This suggests that the associations between kinship intensity and psychology do not hinge on the exposure to the Churches' MFP but hold more generally.
} 
Church exposure are highly correlated, making it hard to disentangle religion more generally from experiencing the medieval Church MFP.

(iv) The focus on Europe allows us to more closely tie the Church's MFP to kinship intensity and psychology. That is, again we demonstrate that within regions, the duration of exposure to the medieval Church is highly predictive of human psychology and kinship intensity. The regression exploits variation in Church exposure up to the year $1500 \mathrm{CE}$, capturing the medieval time when the Church put the most emphasis on its marriage regulations. By focusing on the degree of Medieval Church exposure within each region prior to the $16^{\text {th }}$ century, our analysis provides further evidence that our associations are not merely a Christian effect. All areas in Europe were Christianized by the beginning of the $15^{\text {th }}$ century and thus exposed to Christianity subsequently for many centuries. Moreover, we control for pre- $15^{\text {th }}$ century exposure to monastic houses of five different orders, to help mitigate concerns that religious practices or technological innovations that spread by monasticism bias our results.

(v) We further strengthen the argument that marriage regulations played a decisive role in shaping psychology by focusing on one specific area: the Carolingian Empire. Historians describe an "obsession" regarding the marriage regulations in the area of Carolingian Empire and the predecessor Merovingian kingdom (51). Out of 17 synods in the $6^{\text {th }}$ and early $7^{\text {th }}$ century, 11 addressed marriage regulations. In addition, in the $8^{\text {th }}$ and $9^{\text {th }}$ century, Carolingian rulers Pepin and Charlemagne promoted the creation of a parish structure, incorporated the Church's MFP into secular rule, and implemented public marriages. All of these policies strengthened the MFP (see Section S2 for details) and we find a robust association between the Carolingian Empire, kinship intensity and psychological outcomes. Yet, we also demonstrate that our results do not hinge on the Carolingian Empire, addressing concerns that some other unobserved "Carolingian effect" biases our estimates.

\section{Psychological outcome variables}

Our psychological dependent variables derive from the European Social Survey (ESS). The ESS locates each survey respondent within subnational regions, which allows us to exploit subnational regional variation in the psychological dependent variables. We focus on four outcome variables. In the dimension of impersonal prosociality these are generalized trust and generalized fairness; for the other two dimensions, we created a psychological measure of conformity-obedience and individualism-independence. ${ }^{45}$

Generalized trust. We measure generalized trust by using the ESS question that asks, "Generally speaking would you say that most people can be trusted, or that you can't be too careful in dealing with people?". Individuals answered on an 11-point scale ranging from "0" ("you can't be too careful") to "10" ("most people can be trusted"). Our previous analysis in Section S3.1 has shown that there is no association between generalized trust and kinship intensity at the country level. However, in Section S7, we show that this likely reflects differences in how individuals from different societies understand this question: individuals growing up in societies with more intensive kinship tend to understand the question as referring to trust toward the in-

\footnotetext{
${ }^{45}$ We use the same outcome variables for the children of immigrants analysis in Section S5.
} 
group. ${ }^{46}$ We therefore did not find an association between generalized trust and kinship intensity across countries. Yet, we expect to find an association within countries, especially within Europe, where the question was developed and - even though variation exists - it is more homogenous regarding kinship intensity. In Section S7 we demonstrate that within a country and particularly within European countries, the understanding of the question is more homogenous. First, once country fixed effects are controlled for variation in kinship intensity is weakly significantly associated with the generalized trust question based on the World Value Survey (WVS). Second, the association between out-ingroup trust is considerably stronger in Europe. Lastly, while we demonstrate that the understanding of the generalized trust question depends on kinship intensity this is not the case for the European sub-sample. ${ }^{47}$ This parallels the analysis by Thöni et al. (210), who show that at the individual level (based on student subject's in European countries) the generalized trust question is predictive of behavioral measures of cooperation within countries, while this is not the case at the cross-country level.

Generalized fairness is our second measure. It is based on the question: "Do you think that most people would try to take advantage of you if they got the chance, or would they try to be fair?". Again, individuals answered on an 11-points scale ranging from "0" ("Most people would try to take advantage of me") to "10" ("Most people would try to be fair"). Thöni and co-authors $(209,210)$ show (based on student participants in European countries) how the fairness question relates to beliefs about cooperation of others at the individual level, while Gaechter and Schulz (128) show that it relates to individual dishonesty in their student sample based on 23 countries. For this question, we likewise did not find an association between kinship intensity at the country level, but we expect this to be different when we exploit within-country variation, especially within Europe, for reasons similar to those discussed above for generalized trust.

In our cross-country analysis we demonstrated that intensive kin-networks were predictive of psychological measures in the domains of conformity \& obedience and individualism \& independence. While most of these country-level variables are not available in the ESS at the individual level, we can nevertheless construct measures that proxy these concepts. The ESS contains variables capturing human values (based on Schwarz (221)). Each human value question asked an individual to rate "how much each person is or is not like you." Individuals answered on a 6-point scale varying from "Not like me at all" to "Very much like me". Based on those, we constructed a measure for conformity-obedience and individualism-independence. ${ }^{48}$

Conformity-obedience. This third measure is based on the average of answers to four questions: "Please ... tell me how much each person is or is not like you."

(i) It is important to her/him always to behave properly. She/he wants to avoid doing anything people would say is wrong.

\footnotetext{
${ }^{46}$ Ideally, our dependent variable would capture in-group vs. out-group trust, but the ESS does not contain this question.

${ }^{47}$ The ESS generalized trust question is also a more finely grained trust measure compared to the one in the WVS, which was used in the cross-country analysis.

${ }^{48}$ While similar, the human values questions in the ESS and the WVS differ in their wording and values to some extent. In addition, while the WVS asks 10 or 11 human value questions (depending on wave and country), the ESS asks 21. Based on the ESS, we can therefore make use of a larger set of questions that tap into a similar psychology and thereby follow the classification by Schwartz (193).
} 
(ii) She/he believes that people should do what they are told. She/he thinks people should follow rules at all times, even when no-one is watching.

(iii) It is important to her/him to be humble and modest. She/he tries not to draw attention to herself/himself.

(iv) Tradition is important to her/him. She/he tries to follow the customs handed down by her/his religion or her/his family.

Schwartz (221) groups the first two questions to create his measure of conformity, while the second two questions he groups to form his measure of tradition. It is apparent that all these questions fall in the dimension of conformity \& obedience and thus we decided to pool all four questions into one index. Note that we also use two very similar questions (tradition and proper behavior) based on the WVS in Section S3 and S7, which to some extent gives consistency in the dependent variables across the different levels of analysis.

Individualism-independence. This fourth measure is based on the following two questions:

(i) It is important to her/him to make her/his own decisions about what she/he does. She/he likes to be free and not depend on others.

(ii) Thinking up new ideas and being creative is important to her/him. She/he likes to do things in her/his own original way.

Both questions emphasize individual freedom and independence. Schwarz (221) groups them together under the term "self-direction." One similar item (creativity) based on the WVS is also used in Section S3 and S7 again giving to some extend consistency in the dependent variables across the different levels of analysis.

Both ESS-based human value measures were transformed following Schwartz's (221) recommendation: For each individual, we calculated the average response over all 21 human value questions they were asked (we call this an individual's "average closeness perception to others"). We then subtracted the average closeness perception from each of the two measures. This addresses concerns that instead of capturing the intended psychological trait, the measure is confounded by closeness perceptions.

\section{S4.1. Western Church exposure and psychology across European regions}

In this section, we investigate the reduced-form association between exposure to the Medieval Western Church's MFP and the ESS-based measures of psychological traits in Europe. The analysis is done at the regional level. This allows us to conduct country fixed-effects regressions, ruling out estimation biases due to omitted variables at the country level.

The ESS reports the regions within a country in which the survey was conducted. For each ESS region, we calculated regional measures for the Western Church's MFP. This measure is based on the foundation and presence of Western Church bishoprics within (or near) this region between the year 550 and 1500 . We scaled the variable by 100 years so that it varies between 0 (no church exposure between the year 550 and 1500) and 10 (full church exposure during the period between the year 500 and 1500). See Section S2.3 for more information about this regional measure of the Western Church's MFP. 
To increase power, our aim was to maximize the number of observations of the ESS by using the data from all waves (i.e. Waves 1 to 7). ${ }^{49}$ In some country/wave combinations of the ESS regions are not reported. We therefore could not use the data. In some instances, the ESS regions of a country changed between waves. Two criteria guided the selection of regions in this case: first, we aimed to use the regional classification that is more disaggregated to increase regional variation in our sample. Secondly, in some very rare cases the more finely grained regional aggregation of some waves did not follow widely used regional classifications (for most countries, the ESS regional classification follows the European NUTS scheme). In these cases where a straightforward reconciliation with available sources on national administrative units was not possible, we choose the waves with a more widely used regional classification. This allowed us to create appropriate regional indicators of medieval Church exposure. The sizes of the ESS regions are not homogenous - in some countries, regions are smaller than in others (e.g. Netherlands contains very disaggregated data compared to Germany; see Figure S2.4 in Section S2.3 for a map). Consequently, some regions are a broader average approximation of Church exposure than others. The average number of respondents per region is 516, with a standard deviation of 552 and a median of 303. Population movements decrease the probability of finding the association between within-country variation in Church exposure and psychological outcomes. While we do not have information on the within-country relocation of most individuals, we excluded immigrants and children of immigrants from the analysis.

Table S4.1 reports the regression results of the psychological variables on regional Western Church exposure. Each panel in Table S4.1 corresponds to a different dependent variable (generalized trust, generalized fairness, conformity-obedience, and individualism-independence). In all specifications, we control for country fixed effects, wave fixed effects and basic individual characteristics (gender, age, age squared). Exploiting within-country variation by including country fixed effects rules out that the possibility that the estimations are biased by country-level omitted variables. However, other factors may potentially bias our estimates. For example, geographic variations within a country that impact agricultural practices may also impact kinnetworks and psychology. We therefore control for a baseline set of geographic variables (added in Columns 2-11). These baseline controls parallel those at the country level and include terrain ruggedness, mean distance to the coast $^{50}$, caloric suitability, and absolute latitude. These controls are again intended to capture factors like remoteness, market integration, agricultural techniques, and climate (see Section S8 for details on all regional covariates).

In Column 3, we add additional geographic covariates: precipitation, mean temperature, elevation, and the presence of rivers and lakes (see Section S8 for details). This large set of geographic control variables makes it unlikely that the results are driven by confounding geographic features. Several scholars have emphasized the importance of a European medieval agricultural revolution for Europe's development $(76,179,180)$. Mitterauer (76) emphasized the role of oats and rye in this agricultural revolution. To address the concern that agricultural practices associated with the medieval agricultural revolution drive the results, we add caloric suitability for both oats and for rye in Column 4.

\footnotetext{
${ }^{49}$ ESS Waves 1 to 7 were conducted every two years from 2002 to 2014.

${ }^{50}$ In our cross-country baseline set of covariates, we include mean distance to waterways, but here we use mean distance to the sea.
} 
Country fixed effects address cultural heritage based on common language for most European countries, and they also account for political institutions. However, contemporary borders do not necessarily reflect past political entities that may have a lasting impact on contemporary psychological traits. To address concerns that we are capturing legacies from the Roman Empire, we include the presence of Roman roads in Column 5. This indicator captures not only whether a region was a part of the Roman Empire, but also its remoteness and importance within the Empire to some degree. In Column 6 we control for whether or not a region was part of the Carolingian Empire (see Figure S2.4 for a map of the Carolingian Empire). In Section S4.2, we test the hypothesis that people within the area of the Carolingian Empire, which experienced a stronger enforcement of the MFP, have a different psychology compared to those outside of it. Indeed, we find this to be the case. ${ }^{51}$ However, controlling for the Carolingian Empire allows us to demonstrate that our results do not hinge on the Carolingian Empire, but rather hold independent of it. This addresses concerns that the associations we report in Section S4.3 are driven by some other feature of the Carolingian Empire and not the MFP. The $20^{\text {th }}$ century European East/West divide along the Iron Curtain follows the extension of the Carolingian Empire to some degree (see map in Figure S2.4). In the country-fixed-effect regressions this is particularly relevant for Germany where Eastern parts also experienced a considerably shorter duration of medieval Church exposure. In Column 7 of Table S4.1, we control for whether or not a region has a socialist history. As a robustness check, we demonstrate that our results hold in a sample where we only include regions with a socialist history (see Table S4.2).

In Column 8 we control for the presence of five monastic houses (five indicators). This allows us to control for technological innovation as well as cultural and religious practices that are associated with monasticism. The indicators are based on geo-located data on monasteries that belonged to five different orders: Cluniac, Cistercians, Premonstratensians, Franciscans, and Dominicans. Geo-located data on Cluniac (covering those existing between before 998 to 1109 or later), Dominican (covering those existing between 1216 to 1500), Franciscan (covering those existing around 1300), and Premonstratensians Houses (covering those existing between 1120 to 1500) are based on the Atlas zur Kirchengeschichte (222) and are taken from the Digital Atlas of Roman and Medieval Civilization (DARM, (223)). Cistercian Houses (covering those existing between 1095 and 1675) are based on Donkin (224) and taken from Andersen et al. (222). We created a regional indicator of monastic presence for each order following a procedure similar to the one we used to construct our regional Church exposure indicator based on bishoprics. However, unlike for our regional Church exposure indicator, we could not take the time dimension into account when constructing our monastic presence indicators, due to data limitations. We calculated monastic presence based on all the monastic houses that existed at some point within the period covered (see above for the coverage of each monastic order). This time we drew a smaller radius: unlike bishoprics, monastic houses did not have a parish system and did not fulfill the same administrative function of governing a large area. Thus, we drew a $50 \mathrm{~km}$ radius around each monastic house. Based on pixels that fall within the $50 \mathrm{~km}$ radii we then calculated for

\footnotetext{
${ }^{51}$ Starting in the $6^{\text {th }}$ century, and particularly in the $8^{\text {th }}$ and $9^{\text {th }}$ centuries, the area of the Carolingian Empire was the heartland of the Church's Marriage and Family program. Secular rulers there also supported this ban. See Section S4.2 for more details.
} 
each monastic order the percentage of each region that was exposed to the order. ${ }^{52}$ We note that controlling for monastic presence is very conservative, because the presence of monasteries may have helped to enforce the Church's MFP. In addition, the emergence of widespread monastic movements starting in the $10^{\text {th }}$ century is likely at least partially determined by the Church's MFP: the dissolution of extended kin-group probably fostered monasticism - a form of voluntary non-kin-based corporation (225). Chronologically, many orders started to emerge and spread only after the area in which they were based had experienced the Church's MFP. The Cluniac movement started in the first half of the $10^{\text {th }}$ century in France, both the Cistercian and Premonstratensian movements started at the beginning of the $12^{\text {th }}$ century, and both the Franciscan and Dominican movements started at the beginning of the $13^{\text {th }}$ century.

Column 9 controls for respondent's religious denomination (indicator variables for no denomination, Roman Catholic, Protestant, Eastern Orthodox, other Christian, Jewish, Muslim, other non-Christian) and religiousness. Religiousness is based on the questions: "Regardless of whether you belong to a particular religion, how religious would you say you are?" Respondent's answers range from 0 ("not at all religious") to 10 ("very religious"). This partly addresses concerns that our results are biased by other factors related to religion. To the degree that kinship intensity fosters religiosity (or decreases the probability of becoming an atheist), this control may be endogenous. In Column 10, we control for the educational attainment of individuals. Educational attainment may likewise be endogenous and caused by kinship intensity: individuals brought up in societies with higher kinship intensity may put less emphasis on educational attainment. At the same time controlling for education addresses concerns that the estimates are biased due to some other Church related factor that works through education. For example, that bishoprics may have promoted schooling (cathedral schools) along with the MFP.

Column 11 contains estimates for population density in the year $500 \mathrm{CE}$ and dummy variables for (selfreported) city-size (big city, suburb or outskirts of big city, town or small city, country village, farm or home in countryside). Population density estimates are taken from Goldewijk et al., $(116,117)$ (Section S9). These estimates are based on the country estimates by (226), broken down to the pixel level according to geographic factors that relate to the probability of settlement (e.g. proximity to waterways, temperature). Although these population density estimates are rough approximations, they nevertheless give an indication about population density in the year 500CE at the onset of the Church's MFP. Including population density mitigates concerns that Church exposure was endogenously determined by population density (see also Section $\mathbf{S 2}$ on historic evidence suggesting a large idiosyncratic component in the spread and duration of Church exposure). In addition, we include today's self-reported city size. We do this because our measure of Church exposure is based on bishoprics. As administrative centers, bishoprics may have fostered city growth in the area of the see (227). At the same time, city life may have implications for psychological outcomes. Controlling for city size addresses this concern.

\footnotetext{
${ }^{52}$ In addition to basing the indicator solely on the number of monastic houses within a region, relying on the $50 \mathrm{~km}$ radius is more precise in cases where monasteries are located close to the regional boarder. The distance of $50 \mathrm{~km}$ is equivalent to approximately one day of travelling (115). This distance is smaller than the one we base our regional Church exposure on. Unlike monasteries, bishops had judicial power over larger areas and could rely on a parish system. All results in Table 4.1 are quantitatively and qualitatively very similar for smaller $(10 \mathrm{~km}, 30 \mathrm{~km})$ and larger $(100 \mathrm{~km})$ radii.
} 
All regressions paint a very consistent picture: exposure to the medieval Western Church is associated with higher coefficients for generalized trust, fairness, and individualism-independence, and lower coefficients for conformity-obedience. These regressions demonstrate that the association with medieval Church exposure is robust to the inclusion of country fixed effects: country-level unobservables like infrastructures, social security systems and national-level quality of the rule of law therefore do not influence the estimates. Country fixed effects also control for culture, social norms, and language that are shared between individuals within each country. Moreover, Columns 2, 3 and 4 contain a large set of geographic covariates, making geographic features an unlikely explanation for our finding. Importantly, controlling for institutional legacies like the presence of Roman Roads, exposure to the Carolingian Empire, and a socialist political history does not alter the coefficients much. Only in the regression of individualism-independence on Church exposure do the coefficients become insignificant when controlling for socialist regions (Column 7) or the Carolingian Empire (Column 6), and the latter is not surprising given the Empire's central role in the enforcement of the Church's MFP. We also conduct additional analyses in which we restrict the sample to only socialist regions and find the same associations (Table S4.2). It is therefore unlikely that other institutional features of the Carolingian Empire or socialism drive our results. Column 8 demonstrates that the results are robust to controlling for the presence of the five monastic orders. Column 9 reveals that controlling for an individual's religious denomination and religiousness does not change the covariates. Together, Columns 8 and 9 are evidence of the importance of the separate effect of the medieval Church's MFP, independent of religious practices or features of monasticism. Controlling for education - very possibly an endogenous variable - likewise does not change the coefficients very much (Column 10). This is also the case when controlling for contemporary city size and population density in the year $500 \mathrm{CE}$ (Column 11). 


\begin{tabular}{|c|c|c|c|c|c|c|c|c|c|c|c|}
\hline & (1) & (2) & (3) & (4) & (5) & (6) & (7) & (8) & (9) & (10) & (11) \\
\hline $\begin{array}{l}\text { W. Church exposure } \\
(N=198,449 ; \text { Region }=440) \\
R^{2}\end{array}$ & $\begin{array}{c}0.010^{* * *} \\
(0.003) \\
0.147\end{array}$ & $\begin{array}{c}0.011^{* * *} \\
(0.004) \\
0.147\end{array}$ & $\begin{array}{c}0.011^{* * *} \\
(0.004) \\
0.147\end{array}$ & $\begin{array}{c} \\
0.011^{* * *} \\
(0.004) \\
0.147\end{array}$ & $\begin{array}{c}0.010^{* * * *} \\
(0.004) \\
0.147\end{array}$ & $\begin{array}{c}\text { ralized tr } \\
0.007^{*} \\
(0.004) \\
0.148\end{array}$ & $\begin{array}{c}\text { st (z-score } \\
0.006^{*} \\
(0.004) \\
0.148\end{array}$ & $\begin{array}{c}0.013^{* * *} \\
(0.004) \\
0.147\end{array}$ & $\begin{array}{c}0.011^{* * *} \\
(0.004) \\
0.150\end{array}$ & $\begin{array}{c}0.010^{* * *} \\
(0.004) \\
0.159\end{array}$ & $\begin{array}{c}0.011^{* * *} \\
(0.003) \\
0.148\end{array}$ \\
\hline $\begin{array}{l}\text { W. Church exposure } \\
(N=197,112 ; \text { Region }=440) \\
R^{2}\end{array}$ & $\begin{array}{c}0.011^{* * *} \\
(0.003) \\
0.143 \\
\end{array}$ & $\begin{array}{c}0.012^{* * *} \\
(0.003) \\
0.143 \\
\end{array}$ & $\begin{array}{c}0.011^{* * *} \\
(0.003) \\
0.143 \\
\end{array}$ & $\begin{array}{c}\mathrm{Pa} \\
0.012^{* * *} \\
(0.003) \\
0.143 \\
\end{array}$ & $\begin{array}{c}\text { el 2: Gen } \\
0.012^{* * *} \\
(0.003) \\
0.143 \\
\end{array}$ & $\begin{array}{c}\text { lized fair } \\
0.010^{* * *} \\
(0.003) \\
0.143 \\
\end{array}$ & $\begin{array}{c}\text { ess (z-sco } \\
0.010^{* * *} \\
(0.003) \\
0.143 \\
\end{array}$ & $\begin{array}{l}\text { s) } \\
0.013^{* * *} \\
(0.003) \\
0.143 \\
\end{array}$ & $\begin{array}{c}0.012^{* * *} \\
(0.003) \\
0.145 \\
\end{array}$ & $\begin{array}{c}0.011^{* * *} \\
(0.003) \\
0.150 \\
\end{array}$ & $\begin{array}{c}0.012^{* * *} \\
(0.003) \\
0.143 \\
\end{array}$ \\
\hline $\begin{array}{l}\text { W. Church exposure } \\
(N=179,827 ; \text { Region }=439) \\
R^{2}\end{array}$ & $\begin{array}{c}-0.010^{*} \\
(0.006) \\
0.220 \\
\end{array}$ & $\begin{array}{c}-0.013^{* *} \\
(0.005) \\
0.221 \\
\end{array}$ & $\begin{array}{c}-0.014^{* * *} \\
(0.005) \\
0.221 \\
\end{array}$ & $\begin{array}{c}\text { Pan } \\
-0.016^{* * *} \\
(0.005) \\
0.221 \\
\end{array}$ & $\begin{array}{c}13: \text { Conf } \\
-0.010^{*} \\
(0.005) \\
0.221 \\
\end{array}$ & $\begin{array}{c}\text { mity-obed } \\
-0.009^{*} \\
(0.005) \\
0.221 \\
\end{array}$ & $\begin{array}{c}\text { ence }(\mathrm{z}-\mathrm{sc} \\
-0.010^{*} \\
(0.005) \\
0.221 \\
\end{array}$ & $\begin{array}{l}\text { es) } \\
-0.013^{* *} \\
(0.006) \\
0.221 \\
\end{array}$ & $\begin{array}{c}-0.017^{* * *} \\
(0.005) \\
0.251 \\
\end{array}$ & $\begin{array}{c}-0.012^{* *} \\
(0.005) \\
0.232 \\
\end{array}$ & $\begin{array}{c}-0.011^{* * *} \\
(0.004) \\
0.228 \\
\end{array}$ \\
\hline $\begin{array}{l}\text { W. Church exposure } \\
(N=179,827 ; \text { Region }=439) \\
R^{2}\end{array}$ & $\begin{array}{l}0.010^{* *} \\
(0.004) \\
0.0727\end{array}$ & $\begin{array}{l}0.010^{* *} \\
(0.004) \\
0.0727\end{array}$ & $\begin{array}{l}0.009^{* *} \\
(0.004) \\
0.0730\end{array}$ & $\begin{array}{c}\text { Panel } \\
0.010^{* *} \\
(0.004) \\
0.0728 \\
\end{array}$ & $\begin{array}{c}\text { Individu } \\
0.008^{*} \\
(0.004) \\
0.0729 \\
\end{array}$ & $\begin{array}{c}\text { ism-indep } \\
0.006 \\
(0.005) \\
0.0730 \\
\end{array}$ & $\begin{array}{c}\text { ndence }(\mathrm{z} \\
0.006 \\
(0.004) \\
0.0731 \\
\end{array}$ & $\begin{array}{l}\text { cores) } \\
0.009^{* *} \\
(0.005) \\
0.0728 \\
\end{array}$ & $\begin{array}{c}0.012^{* * *} \\
(0.004) \\
0.0816\end{array}$ & $\begin{array}{l}0.008^{* *} \\
(0.004) \\
0.0888\end{array}$ & $\begin{array}{l}0.009^{* *} \\
(0.003) \\
0.0759\end{array}$ \\
\hline Geographic baseline & - & Yes & Yes & Yes & Yes & Yes & Yes & Yes & Yes & Yes & Yes \\
\hline Further geo. Controls & - & - & Yes & - & - & - & - & - & - & - & - \\
\hline Oats suit. \& rye suit. & - & - & - & Yes & - & - & - & - & - & - & - \\
\hline Roman roads & - & - & - & - & Yes & - & - & - & - & - & - \\
\hline Carolingian emp. & - & - & - & - & - & Yes & - & - & - & - & - \\
\hline Socialist & - & - & - & - & - & - & Yes & - & - & - & - \\
\hline Monastic presence & - & - & - & - & - & - & - & Yes & - & - & - \\
\hline $\begin{array}{l}\text { Religious denom. \& } \\
\text { Religiousness }\end{array}$ & - & - & - & - & - & - & - & - & Yes & - & - \\
\hline Educational attainment & - & - & - & - & - & - & - & - & - & Yes & - \\
\hline $\begin{array}{l}\text { Pop. dens. 500CE \& } \\
\text { city size }\end{array}$ & - & - & - & - & - & - & - & - & - & - & Yes \\
\hline $\begin{array}{l}\text { Country \& wave FE } \\
\text { basic indi. Controls }\end{array}$ & Yes & Yes & Yes & Yes & Yes & Yes & Yes & Yes & Yes & Yes & Yes \\
\hline
\end{tabular}

Table S4.1: Individual-level OLS regression of ESS-based psychological variables (z-scores) on Church exposure. Each column reports on four regressions,

each with a different psychological outcome variable. All columns control for country and survey wave fixed effects, as well as basic individual characteristics (gender, age, and age squared). Columns 2 to 10 contain the set of geographic baseline controls (ruggedness, distance to the coast, caloric suitability, and absolute latitude). Column 3 contains an additional set of geographic controls (precipitation, mean temperature, elevation, and presence of river/lake). Column 4 controls for caloric suitability for oats and rye; Column 5 for Roman roads; Column 6 for exposure to the Carolingian Empire; Column 7 for socialist history; and Column 8 for exposure to Cluniac, Cistercians, Premonstratensians, Franciscans, and Dominicans houses. Column 9 contains indicator variables for the religious denomination of the respondents (no denomination, Roman Catholic, Protestant, Eastern Orthodox, other Christian, Jewish, Muslim, other nonChristian) and self-reported religiousness (on a scale from 0 to 10). Column 10 controls for educational attainment (indicator variables for primary education or less, secondary, and tertiary education), while Column 11 controls for population density estimates in 500CE and current size of the city in which the respondent lives. Robust standard errors clustered at the 442 or 441 regions that are reported in parentheses. * $P \leq 0.1$, ** $P \leq 0.05$, *** $\mathrm{P} \leq 0.01$ (two-sided). 


\section{Robustness checks}

\section{i. Robustness check: Sub-sample of socialist regions}

Here we demonstrate that the reduced form association between Church exposure and the attitudinal ESS measures also holds when including only regions with a socialist history in the analysis. This demonstrates that the psychological variation does not rely on differences between East and West Germany, the Italian North-South divide, or the Carolingian Empire. Both the East/West divide in Germany and the North/South divide in Italy have received a considerably degree of attention in the literature and different explanation have been brought forward to explain the differences. Focusing only on regions with a socialist history demonstrates that the results do not rest on the differences within Germany and Italy but hold more generally. The results are reported in Table S4.2. As in the previous analysis, Church exposure is associated with higher generalized trust, generalized fairness, and individualism-independence, but lower conformity-obedience.

\begin{tabular}{|c|c|c|c|c|c|c|c|c|}
\hline & \multicolumn{2}{|c|}{ Gen. trust } & \multicolumn{2}{|c|}{ Gen. fairness } & \multicolumn{2}{|c|}{$\begin{array}{l}\text { Conformity- } \\
\text { obedience }\end{array}$} & \multicolumn{2}{|c|}{$\begin{array}{l}\text { Individualism- } \\
\text { independence }\end{array}$} \\
\hline & (1) & (2) & (3) & (4) & (5) & (6) & (7) & $(8)$ \\
\hline W. Church exposure & $0.012^{*}$ & $0.011^{*}$ & $0.016^{* * *}$ & $0.015^{* * *}$ & $-0.017^{* * *}$ & $-0.017^{* * *}$ & $0.015^{* * *}$ & $0.013^{* * *}$ \\
\hline (Regions: 191) & $(0.007)$ & $(0.007)$ & $(0.006)$ & $(0.006)$ & $(0.006)$ & $(0.006)$ & $(0.005)$ & $(0.005)$ \\
\hline$N$ & 86880 & 86880 & 85817 & 85817 & 77842 & 77842 & 77842 & 77842 \\
\hline$R^{2}$ & 0.0492 & 0.0495 & 0.0508 & 0.0511 & 0.247 & 0.248 & 0.0780 & 0.0783 \\
\hline Geographic baseline & - & Yes & - & Yes & - & Yes & - & Yes \\
\hline $\begin{array}{l}\text { Country \& wave FE } \\
\text { basic ind. char. }\end{array}$ & Yes & Yes & Yes & Yes & Yes & Yes & Yes & Yes \\
\hline
\end{tabular}

Table S4.2: Individual-level OLS regression of the ESS-based psychological variables (z-scores) on regional Western Church exposure (in 100 years). Only individuals who reside in a region with a socialist history are included. All columns control for country and survey wave fixed effects, as well as basic individual-level characteristics (gender, age, and age squared). Columns 2, 4, 6, and 8 contain the set of geographic baseline controls (ruggedness, distance to the coast, caloric suitability, and absolute latitude). Robust standard errors clustered at the 191 regions are reported in parentheses. ${ }^{*} P \leq 0.1$, ** $P \leq 0.05, * * * \mathrm{P} \leq 0.01$ (two-sided).

\section{ii. Robustness check: Alternative measures of Church exposure}

The second set of robustness checks concerns our measure of Church exposure. Our medieval Church exposure variable is based on a $100 \mathrm{~km}$ radius around bishoprics. Note that this measure is an approximation, since some bishoprics (particularly in Scandinavia and Central Europe) covered large areas, while others (particularly in Italy and France) administered considerably smaller areas (see Section S2 for details). Here we demonstrate that the results are robust to basing the Church exposure variable on larger or (slightly) smaller radiuses around bishoprics. Table $\mathbf{S 4 . 3}$ reports the results. It reveals qualitatively similar results for a slightly smaller radius $(75 \mathrm{~km})$ or radiuses up to about $150 \mathrm{~km}$. Effect sizes and significance seems to be generally maximized if regional Church exposure is based on a $125 \mathrm{~km}$ radius. ${ }^{53}$ Lastly, we constructed an indicator, which is weighted by population density estimates (of the year 500AD) and based on a $100 \mathrm{~km}$ radius. This indicator reveals larger coefficients with higher significance levels compared to the nonpopulation weighted one.

\footnotetext{
${ }^{53}$ In this case, bishoprics in the year 1500 cover $71 \%$ of Catholic Europe, or $94 \%$ when sparsely-populated Scandinavia is excluded
} 


\begin{tabular}{|c|c|c|c|c|c|c|c|c|}
\hline & \multicolumn{2}{|c|}{ Gen. trust } & \multicolumn{2}{|c|}{ Gen. fairness } & \multicolumn{2}{|c|}{$\begin{array}{c}\text { Conformity- } \\
\text { obedience }\end{array}$} & \multicolumn{2}{|c|}{$\begin{array}{l}\text { Individualism- } \\
\text { independence }\end{array}$} \\
\hline & (1) & (2) & (3) & (4) & $(5)$ & (6) & (7) & $(8)$ \\
\hline W. Church exposure & $0.007^{*}$ & $0.008^{* *}$ & 0.005 & 0.006 & $-0.016^{* * *}$ & $-0.015^{* * *}$ & $0.008^{* *}$ & $0.007^{* *}$ \\
\hline (50 $\mathrm{km}$ radius) & $(0.004)$ & $(0.004)$ & $(0.003)$ & $(0.003)$ & $(0.004)$ & $(0.004)$ & $(0.003)$ & $(0.003)$ \\
\hline$R^{2}$ & 0.147 & 0.147 & 0.142 & 0.142 & 0.220 & 0.221 & 0.0726 & 0.0726 \\
\hline W. Church exposure & $0.009^{* *}$ & $0.010^{* * *}$ & $0.007^{* *}$ & $0.008^{* *}$ & $-0.014^{* * *}$ & $-0.015^{* * *}$ & $0.009^{* * *}$ & $0.009^{* *}$ \\
\hline (75 $\mathrm{km}$ radius) & $(0.003)$ & $(0.004)$ & $(0.003)$ & $(0.003)$ & $(0.004)$ & $(0.004)$ & $(0.003)$ & $(0.003)$ \\
\hline$R^{2}$ & 0.147 & 0.147 & 0.142 & 0.142 & 0.220 & 0.221 & 0.0726 & 0.0727 \\
\hline W. Church exposure & $0.010^{* * *}$ & $0.011^{* * *}$ & $0.011^{* * *}$ & $0.012^{* * *}$ & $-0.010^{*}$ & $-0.013^{* *}$ & $0.010^{* *}$ & $0.010^{* *}$ \\
\hline (100km radius) & $(0.003)$ & $(0.004)$ & $(0.003)$ & $(0.003)$ & $(0.006)$ & $(0.005)$ & $(0.004)$ & $(0.004)$ \\
\hline$R^{2}$ & 0.147 & 0.147 & 0.143 & 0.143 & 0.220 & 0.221 & 0.0727 & 0.0727 \\
\hline W. Church exposure & $0.011^{* *}$ & $0.013^{* * *}$ & $0.014^{* * *}$ & $0.015^{* * *}$ & $-0.013^{* *}$ & $-0.016^{* * *}$ & $0.014^{* * *}$ & $0.014^{* * *}$ \\
\hline (125km radius) & $(0.004)$ & $(0.004)$ & $(0.004)$ & $(0.004)$ & $(0.005)$ & $(0.005)$ & $(0.003)$ & $(0.004)$ \\
\hline$R^{2}$ & 0.147 & 0.147 & 0.143 & 0.143 & 0.220 & 0.221 & 0.0728 & 0.0729 \\
\hline W. Church exposure & $0.011^{* *}$ & $0.014^{* * *}$ & $0.015^{* * *}$ & $0.016^{* * *}$ & -0.009 & $-0.013^{* *}$ & $0.015^{* * *}$ & $0.015^{* * *}$ \\
\hline (150km radius) & $(0.005)$ & $(0.005)$ & $(0.004)$ & $(0.004)$ & $(0.006)$ & $(0.006)$ & $(0.004)$ & $(0.004)$ \\
\hline$R^{2}$ & 0.147 & 0.147 & 0.143 & 0.143 & 0.220 & 0.221 & 0.0728 & 0.0728 \\
\hline W. Church exposure & $0.013^{* * *}$ & $0.016^{* * *}$ & $0.017^{* * *}$ & $0.018^{* * *}$ & -0.005 & -0.009 & $0.014^{* * *}$ & $0.014^{* * *}$ \\
\hline ( $175 \mathrm{~km}$ radius) & $(0.005)$ & $(0.005)$ & $(0.004)$ & $(0.004)$ & $(0.008)$ & $(0.007)$ & $(0.005)$ & $(0.005)$ \\
\hline$R^{2}$ & 0.147 & 0.147 & 0.143 & 0.143 & 0.219 & 0.220 & 0.0727 & 0.0727 \\
\hline W. Church exposure & $0.015^{* * *}$ & $0.019^{* * *}$ & $0.017^{* * *}$ & $0.018^{* * *}$ & -0.005 & -0.009 & $0.011^{* *}$ & $0.011^{*}$ \\
\hline (200km radius) & $(0.005)$ & $(0.005)$ & $(0.005)$ & $(0.005)$ & $(0.008)$ & $(0.008)$ & $(0.005)$ & $(0.006)$ \\
\hline$R^{2}$ & 0.147 & 0.147 & 0.143 & 0.143 & 0.219 & 0.220 & 0.0726 & 0.0726 \\
\hline W. Church exposure & $0.012^{* * *}$ & $0.013^{* * *}$ & $0.014^{* * *}$ & $0.015^{* * *}$ & $-0.012^{* *}$ & $-0.014^{* * *}$ & $0.014^{* * *}$ & $0.014^{* * *}$ \\
\hline Population weights (100km radius) & $(0.004)$ & $(0.004)$ & $(0.004)$ & $(0.004)$ & $(0.005)$ & $(0.005)$ & $(0.003)$ & $(0.003)$ \\
\hline$R^{2}$ & 0.147 & 0.147 & 0.143 & 0.143 & 0.220 & 0.221 & 0.0728 & 0.0729 \\
\hline Geographic baseline & - & Yes & - & Yes & - & Yes & - & Yes \\
\hline Country \& wave FE; basic indv. char. & Yes & Yes & Yes & Yes & Yes & Yes & Yes & Yes \\
\hline$N$ & 198449 & 198449 & 197112 & 197112 & 179827 & 179827 & 179827 & 179827 \\
\hline Regions & 440 & 440 & 440 & 440 & 439 & 439 & 439 & 439 \\
\hline
\end{tabular}

\section{S4.2. The Carolingian Empire and contemporary psychology}

The previous section has established a robust reduced-form association between medieval Church exposure and the ESS-based psychological measures. In this section, we test the hypothesis that the Carolingian Empire impacted those psychological outcomes. This analysis serves two purposes.

First and foremost, historians have consistently pointed out that the area of the Carolingian Empire was a forerunner in the implementation and enforcement of the Western Church's MFP. Historians speak of an obsession with kin marriages in Merovingian France (51) during the $6^{\text {th }}$ and beginning of the $7^{\text {th }}$ centuries. A further tightening of the MFP occurred under Pepin and Charlemagne at the end of the $8^{\text {th }}$ and beginning of the $9^{\text {th }}$ centuries. They incorporated the Church's MFP into secular rule, promoted the creation of a parish Church structure, and decreed that legitimate marriages had to be public and elders and priests had to be consulted to rule out consanguineous marriages (see Section S2 for details).

Second, compared to our medieval Church exposure measures (based on radiuses around bishoprics), the boundaries of the Carolingian Empire are more distinct (even though borders in the $9^{\text {th }}$ century were not as clearly defined as today's borders). In some instances, radiuses around bishoprics overlap with regions that 
were under the control of other religious organizations. For example, our medieval Church exposure variable reaches into areas of the Lombard/Byzantine South Italy and Islamic Spain.

The Carolingian Empire spanned an area that goes far beyond what constitutes modern day France (Figure S2.4 maps the boundaries of the Carolingian Empire). Belgium, the Netherlands, Luxembourg and Switzerland were wholly part of it. It further extended into Spain, Northern Italy, most of Slovenia, Austria, parts of Germany, and small parts of Croatia. Within today's France, Brittany was not a part of the Carolingian Empire, but was under the influence of the Celtic Church. We coded whether and what percentage of a given ESS region in a country was part of the Carolingian Empire and exploit this regional, within-country variation in regression analyses.

Table S4.4 reports the reduced form regressions of the ESS-based measures on the presence of the Carolingian Empire. The regressions follow the same specifications as in Section S4.1. The results show highly significant associations, all in the predicted directions, between the Carolingian Empire and generalized trust, fairness, conformity-obedience, and individualism-independence. These associations are robust to the inclusion of country fixed effects, the geographic control variables, Roman roads, individual religious denomination and religiousness, educational attainment, population density estimates of 500CE, and city size. They are not robust to controlling for a socialist history. To rule out that the regressions merely pick up the East/West divide in Germany (the only country with within-country variation in social history), we excluded Germany in Columns 10 and 11 and still find significant associations. 


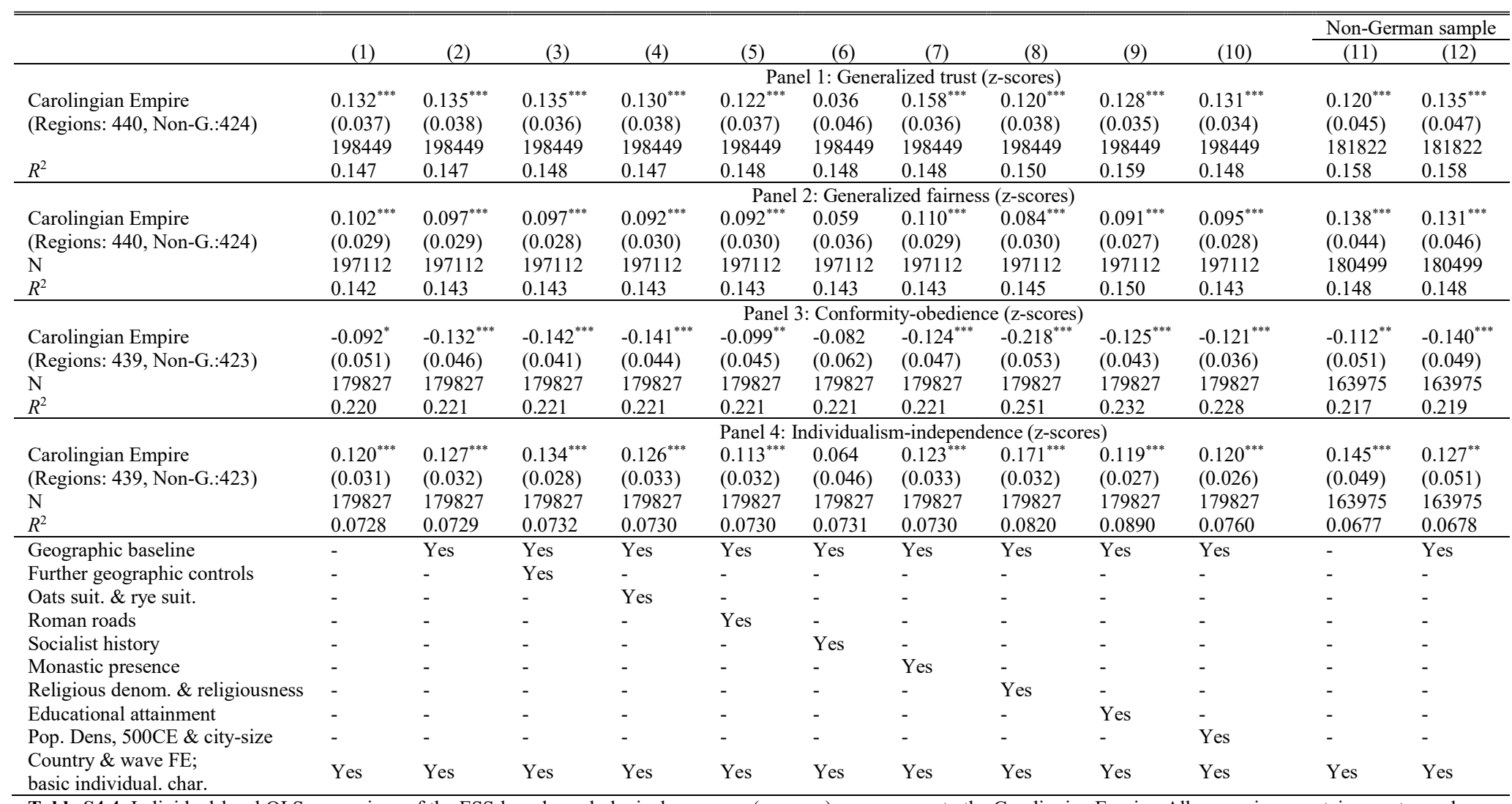

basic individual. char.

Table S4.4: Individual-level OLS regressions of the ESS-based psychological measures (z-scores) on exposure to the Carolingian Empire. All regressions contain country and wave ruggedness, distance to the coast, caloric suitability, and abe age squared, and gender). Column distance to river \& lakes); Column 4 for caloric suitability for oats and rye; Column 5 for Roman roads; Column 6 for socialist history; Column 7 for exposure to Cluniac, Cistercians, Premonstratensians, Franciscans, and Dominicans houses; Column 8 for religiousness and dummy variables of religious adherence (Catholic, Protestant, Eastern Orthodox, other Christians, Jewish, Muslim, other non-Christian religions); Column 9 for educational attainment (fraction primary education or less, fraction secondary, fraction tertiary education); and Column 10 controls for population density estimates of the year 500CE and city size. Columns 11 and 12 report regressions in the sub-sample in which Germany is excluded. Robust standard errors clustered on regions are reported in parentheses. * $P \leq 0.1,{ }^{* *} P \leq 0.05, * * * \mathrm{P} \leq 0.01$ (two-sided) 


\section{S4.3. Kinship intensity and psychology in regions of Spain, France, Italy and Turkey}

Having established a robust reduced-form relationship between medieval Church exposure, the Carolingian Empire and contemporary psychological outcomes, we now directly focus on the relationship between kinship intensity, as proxied by cousin marriages, and the psychological outcomes. We focus on four countries for which regional data on cousin marriages is available: France, Spain, Italy, and Turkey. The data on cousin marriages in regions of France, Spain and Italy are based on Church dispensations, while in Turkey they are based on the Demographic and Health Survey (DHS) (see Section S1 for details). We were able to directly match regional cousin marriage rates to the ESS regions. ${ }^{54}$ Figure $\mathbf{S 4 . 1}$ reveals a strong association between the log percentage of cousin marriage and the standardized ESS-based outcome measures. In all cases the Spearman's $\rho$ is highly significant.

These raw correlations are corroborated by a regression analysis that includes country fixed effects. The results are presented in Table $\mathbf{S 4 . 5}$. The regression specifications parallel the previous reduced-form analysis of Section S4.1 and S4.2 (except for the specifications that controls for whether a region has a socialist history, since none of the regions analyzed here have one). For generalized trust and fairness, the estimated coefficients consistently show a significant association. Only when controlling for the Carolingian empire or monastic presence of five orders the coefficient for generalized fairness becomes insignificant. This is not so surprising given the strong association between the Carolingian empire and cousin marriages (see Table S4.6). Doubling cousin marriage decreases generalized trust by about $-0.09 \approx-0.135 \cdot \ln (2)$ and generalized fairness by $-0.08 \approx-0.116 \cdot \ln (2)$ standard deviations. Even though the analysis rests on only 68 regions, the coefficients are quite stable to the introduction of additional covariates. This suggest that once log percent cousin marriage is controlled for, geographic and political features are not very important in explaining the psychological outcome variables. Even when controlling for educational attainment- a variable that is likely negatively impacted by cousin marriage- the coefficients remain significant and do not decrease by much. While the coefficients go in the expected directions for conformity-obedience and individualismindependence, they are mostly not significant. Given that the regressions rest on only 67 regions and country fixed effects take out the between-country variation, this is not too surprising. The raw correlations in Figure S4.1 are all significant.

\footnotetext{
${ }^{54}$ The ESS classification of regions in France changed between waves - we only used the more recent ESS waves that follow the common NUTS regional classification, are more finely grained and could be straightforwardly matched to the regional cousin marriages rates based on Church dispensations.
} 

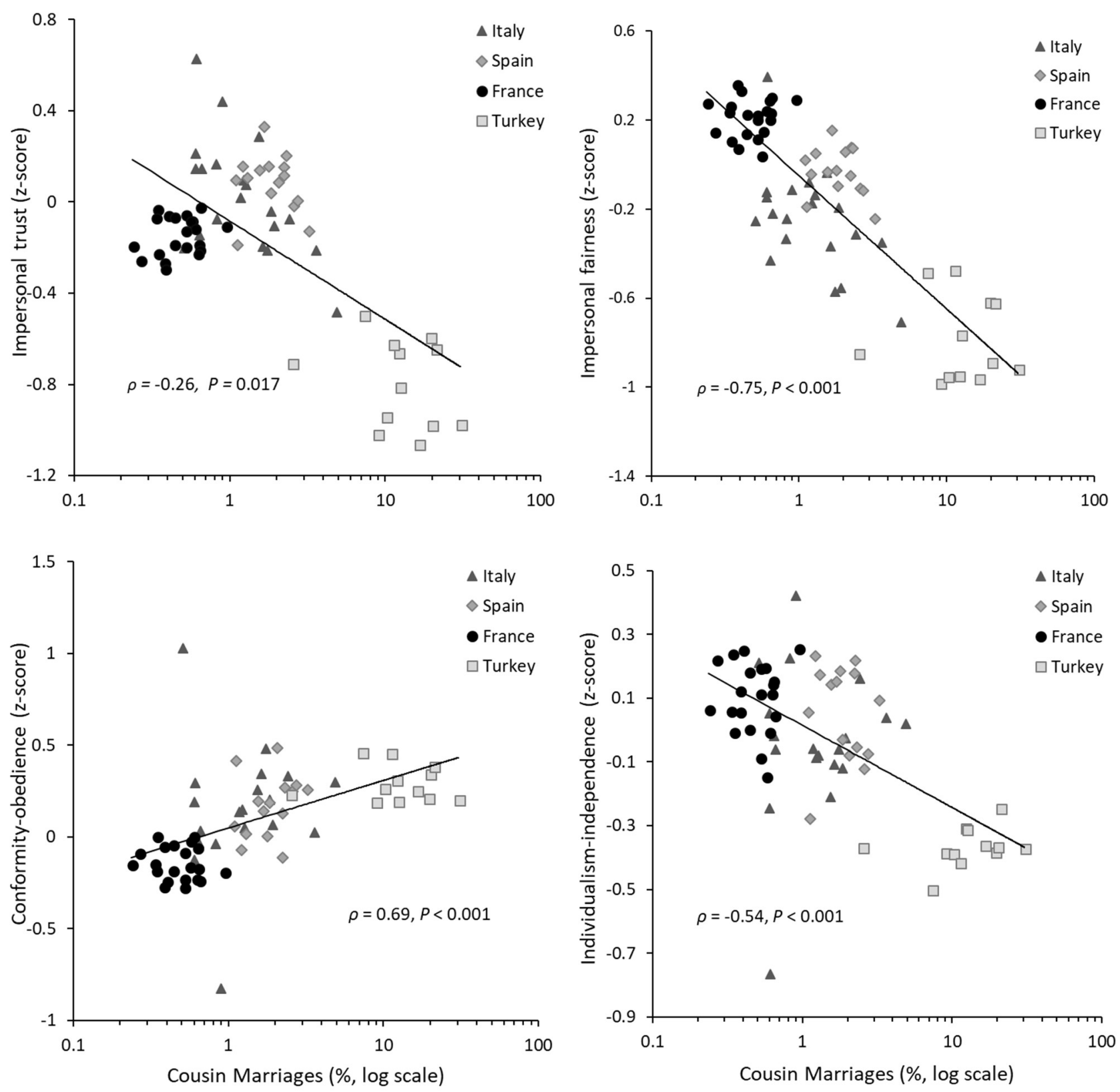

Figure S4.1: Percent cousin marriage and generalized trust (upper left), generalized fairness (upper right), conformity-obedience (lower left), and individualism-independence (lower right) in regions of Spain, France, Italy and Turkey. Spearman's $\rho$ and the associated $P$-values are also reported. 


\begin{tabular}{|c|c|c|c|c|c|c|c|c|c|c|}
\hline & (1) & (2) & (3) & (4) & $(5)$ & (6) & $(7)$ & $(8)$ & (9) & $(10)$ \\
\hline $\begin{array}{l}\text { Log \% cousin marriage } \\
\text { (N: } 17689 \text {, Regions: } 68 \text { ) } \\
R^{2}\end{array}$ & $\begin{array}{l}-0.135^{* * *} \\
(0.041) \\
0.153\end{array}$ & $\begin{array}{l}-0.106^{* * *} \\
(0.038) \\
0.155\end{array}$ & $\begin{array}{l}-0.111^{* * *} \\
(0.041) \\
0.157\end{array}$ & $\begin{array}{l}\text { Panel } \\
-0.105^{* *} \\
(0.047) \\
0.155\end{array}$ & $\begin{array}{l}\text { Generalize } \\
-0.108^{* * *} \\
(0.039) \\
0.155\end{array}$ & $\begin{array}{l}\text { trust }(\mathrm{z}-\mathrm{s} \\
-0.110^{* *} \\
(0.043) \\
0.155\end{array}$ & $\begin{array}{l}\text { ores) } \\
-0.052^{*} \\
(0.031) \\
0.159\end{array}$ & $\begin{array}{l}-0.109^{* * *} \\
(0.039) \\
0.158\end{array}$ & $\begin{array}{l}-0.096^{* *} \\
(0.038) \\
0.170\end{array}$ & $\begin{array}{l}-0.094^{* *} \\
(0.037) \\
0.157\end{array}$ \\
\hline $\begin{array}{l}\text { Log \% cousin marriage } \\
\text { (N: } 17593 \text {, Regions: } 68 \text { ) } \\
R^{2}\end{array}$ & $\begin{array}{l}-0.116^{* * *} \\
(0.043) \\
0.142 \\
\end{array}$ & $\begin{array}{l}-0.094^{* *} \\
(0.040) \\
0.143 \\
\end{array}$ & $\begin{array}{l}-0.090^{*} \\
(0.048) \\
0.145 \\
\end{array}$ & $\begin{array}{l}\text { Panel 2: } \\
-0.086^{*} \\
(0.049) \\
0.143 \\
\end{array}$ & $\begin{array}{l}\text { Jeneralized } \\
-0.094^{* *} \\
(0.040) \\
0.143 \\
\end{array}$ & $\begin{array}{l}\text { fairness }(\mathrm{z} \\
-0.070 \\
(0.043) \\
0.144 \\
\end{array}$ & $\begin{array}{l}\text { cores }) \\
-0.042 \\
(0.037) \\
0.146 \\
\end{array}$ & $\begin{array}{l}-0.096^{* *} \\
(0.040) \\
0.144 \\
\end{array}$ & $\begin{array}{l}-0.085^{* *} \\
(0.041) \\
0.152 \\
\end{array}$ & $\begin{array}{l}-0.083^{* *} \\
(0.039) \\
0.146 \\
\end{array}$ \\
\hline $\begin{array}{l}\text { Log \% cousin marriage } \\
\text { (N: } 15350 \text {, Regions: 67) } \\
R^{2}\end{array}$ & $\begin{array}{l}0.076^{*} \\
(0.042) \\
0.200 \\
\end{array}$ & $\begin{array}{l}0.068 \\
(0.048) \\
0.200 \\
\end{array}$ & $\begin{array}{l}0.011 \\
(0.046) \\
0.202 \\
\end{array}$ & $\begin{array}{l}\text { Panel 3: } \\
0.028 \\
(0.052) \\
0.201 \\
\end{array}$ & $\begin{array}{l}\text { onformity-o } \\
0.065 \\
(0.048) \\
0.201 \\
\end{array}$ & $\begin{array}{l}\text { edience }( \\
0.053 \\
(0.053) \\
0.201 \\
\end{array}$ & $\begin{array}{l}\text {-scores) } \\
0.069^{*} \\
(0.039) \\
0.205 \\
\end{array}$ & $\begin{array}{l}0.039 \\
(0.040) \\
0.260 \\
\end{array}$ & $\begin{array}{l}0.053 \\
(0.045) \\
0.215 \\
\end{array}$ & $\begin{array}{l}0.054 \\
(0.044) \\
0.205\end{array}$ \\
\hline $\begin{array}{l}\text { Log } \% \text { cousin marriage } \\
\text { (N: } 15350, \text { Regions: } 67) \\
R^{2}\end{array}$ & $\begin{array}{l}-0.035 \\
(0.039) \\
0.0523 \\
\end{array}$ & $\begin{array}{l}-0.024 \\
(0.048) \\
0.0532 \\
\end{array}$ & $\begin{array}{l} \\
-0.017 \\
(0.050) \\
0.0542 \\
\end{array}$ & $\begin{array}{l}\text { anel 4: Ind } \\
0.012 \\
(0.047) \\
0.0543 \\
\end{array}$ & $\begin{array}{l}\text { idualism-in } \\
-0.023 \\
(0.048) \\
0.0532 \\
\end{array}$ & $\begin{array}{l}\text { dependenc } \\
-0.020 \\
(0.050) \\
0.0532 \\
\end{array}$ & $\begin{array}{l}\text { (z-scores) } \\
-0.013 \\
(0.036) \\
0.0573 \\
\end{array}$ & $\begin{array}{l}-0.007 \\
(0.042) \\
0.0707 \\
\end{array}$ & $\begin{array}{l}-0.006 \\
(0.044) \\
0.0694 \\
\end{array}$ & $\begin{array}{l}-0.015 \\
(0.046) \\
0.0555 \\
\end{array}$ \\
\hline Geographic baseline & - & Yes & Yes & Yes & Yes & Yes & Yes & Yes & Yes & Yes \\
\hline Further geographic contr. & - & - & Yes & - & - & - & - & - & - & - \\
\hline Oats suit. \& rye suit. & - & - & - & Yes & - & - & - & - & - & - \\
\hline Roman roads & - & - & - & - & Yes & - & - & - & - & - \\
\hline Carolingian empire & - & - & - & - & - & Yes & - & - & - & - \\
\hline Monastic presence & - & - & - & - & - & - & Yes & - & - & - \\
\hline $\begin{array}{l}\text { Religious denom. } \\
\text { \& religiousness }\end{array}$ & - & - & - & - & - & - & - & Yes & - & - \\
\hline Educational attainment & - & - & - & - & - & - & - & - & Yes & - \\
\hline $\begin{array}{l}\text { Pop. Dens. 500CE } \\
\text { \& city size }\end{array}$ & - & - & - & - & - & - & - & - & - & Yes \\
\hline $\begin{array}{l}\text { Country \& wave FE; } \\
\text { basic ind. char. }\end{array}$ & Yes & Yes & Yes & Yes & Yes & Yes & Yes & Yes & Yes & Yes \\
\hline $\begin{array}{l}\text { Table S4.5: Individual-le } \\
\text { contain country fixed effe } \\
\text { effects and basic individu } \\
\text { ruggedness, distance to th } \\
\text { temperature, elevation, dis } \\
\text { the Carolingian Empire; } \\
\text { for individuals' religious } \\
\text { and religiousness; Columr } \\
\text { Column } 11 \text { for population } \\
\text { regions in the sample are r }\end{array}$ & $\begin{array}{l}\text { el OLS o } \\
\text { ts for the } \\
\text { l-level cor } \\
\text { coast, ca } \\
\text { ance to ri } \\
\text { olumn } 7 \mathrm{f} \\
\text { nominatic } \\
10 \text { for in } \\
\text { density es }\end{array}$ & $\begin{array}{l}\text { the ESS-b } \\
\text { ur countri } \\
\text { ols (gend } \\
\text { ic suitabi } \\
\text { r \& lakes) } \\
\text { exposure } \\
\text { (Catholic } \\
\text { iduals' ec } \\
\text { nates for t }\end{array}$ & $\begin{array}{l}\text { and abs } \\
\text { olumn } 4 \\
\text { Cluniac, } \\
\text { otestant, } \\
\text { tional att } \\
\text { year } 500\end{array}$ & $\begin{array}{l}\text { ical me } \\
\text { his analy } \\
\text { ared). } \\
\text { te latitu } \\
\text { caloric } \\
\text { tercians } \\
\text { tern Or } \\
\text { ment (p } \\
\text { and (co }\end{array}$ & $\begin{array}{l}\text { es (z-sco } \\
\text { Spain, It } \\
\text { mn } 2 \text { adc } \\
\text { Column } \\
\text { ability fo } \\
\text { emonstra } \\
\text { ox, other } \\
\text { ary educe } \\
\text { aporary) }\end{array}$ & $\begin{array}{l}\text { on the } \\
\text { France } \\
\text { he basel } \\
\text { controls } \\
\text { ats and } \\
\text { sians, F } \\
\text { iristians, } \\
\text { n or les } \\
\text { size. R }\end{array}$ & $\begin{array}{l}\text { set of } \\
\text { furthe } \\
\text { Colun } \\
\text { ciscans, } \\
\text { wish, M } \\
\text { econdal } \\
\text { ist stan }\end{array}$ & $\begin{array}{l}\text { graphic } \\
\text { for Ror } \\
\text { Domir } \\
\text { m, othe } \\
\text { ducation } \\
\text { errors }\end{array}$ & $\begin{array}{l}\text { iage. A } \\
\text { de surv } \\
\text { trol var } \\
\text { riables } \\
\text { roads; } \\
\text { ns hous } \\
\text { n-Chris } \\
\text { ttiary ec } \\
\text { tered or }\end{array}$ & $\begin{array}{l}\text { regressions } \\
\text { wave fixed } \\
\text { les (terrain } \\
\text { ecipitation, } \\
\text { lumn } 6 \text { for } \\
\text { Column } 8 \\
\text { n religions) } \\
\text { cation); and } \\
\text { he } 68 \text { or } 67\end{array}$ \\
\hline
\end{tabular}




\section{S4.4. Church exposure, Carolingian Empire and kinship intensity}

We argue that the Church's MFP affects psychological outcomes today through its impact on kinship intensity. Sections S4.1 and S4.2 have established a reduced form relationship between Church exposure and the Carolingian Empire on the one hand, and the ESS-based psychological outcome variables on the other hand. In Section S4.3, we demonstrated that $20^{\text {th }}$ century regional cousin marriages are predictive of the psychological outcome variables (in a sample of four countries). Here, we shed light on the effect of regional variation in Western Church exposure and the Carolingian Empire on kinship intensity. Kinship intensity is proxied by log percent cousin marriage. The regressions are based on the four countries where we have regional data on cousin marriage (Spain, France, Italy and Turkey).

We expect to find a stronger effect regarding exposure to the Carolingian Empire for two reasons. First, as mentioned before, the area of the Carolingian Empire experienced a comparable stricter implementation and enforcement. For example, northwestern regions of Spain, which likewise score high on Western Church exposure experienced a less strict enforcement because they were outside the realm of the Carolingian Empire (see Figure S2.4 for a map on the Carolingian Empire). Secondly, historic accounts and admixture studies suggest that there were non-negligible relocations of Moriscos from southern Spain to northwestern areas (e.g. Castile and Leon, and Galicia) after the year $1500 \mathrm{CE}$ (228). Thirdly, regional Church exposure is a noisier measure than the Carolingian Empire indicator: the former is an approximation based on a $100 \mathrm{~km}$ radius around bishoprics within the realm of the Catholic Church. It therefore reaches into territories of South Italy and Spain that were less exposed to the Western Church's MFP. Lastly, the region of Brittany in northwestern France was not part of the Carolingian Empire and was under the influence of the Celtic Church. Yet, our measure contains these bishoprics under Celtic influence since an exact date when they were more firmly integrated into the Western Church is lacking but occurred sometime in the $9^{\text {th }}$ century (those bishoprics were also hardly represented in Synods banning cousin marriage).

Table S4.6 reports the regression analysis. The specifications largely parallel the previous ones in Sections S4.1-S4.3. However, this time the unit of observation is the region since there is no individual variation in the dependent variable. The specification thus does not control for individual-level characteristics. Most of the within-country variation in Church exposure in Spain and Italy stems from conquests; as discussed in Section S2, the outcomes of wars during this period carry a large random component (see Section S2 for details). In the case of Spain and Italy, these conquests exhibit a north/south gradient. Controlling for absolute latitude thus introduces a covariate that exhibits a high degree of collinearity with Church exposure. ${ }^{55}$ In Columns 1 to 8, we therefore report the regressions excluding the control variable absolute latitude, while it is included in Columns 9 to 14. In Column 1, we estimate the regression without country fixed effects. This allows us to see how much of the variation in log percent cousin marriage is explained by exposure to the Church or the Carolingian Empire.

\footnotetext{
${ }^{55}$ The Church exposure variable does not capture that Brittany in the Northwest of France was in the realm of the Celtic Church for some centuries. So it is lacking the source of variation, which is not following the North/South gradient.
} 
The regression reveals an association between $20^{\text {th }}$ century cousin marriage and both Western Church exposure and the Carolingian Empire (Columns 1 and 2). Column 1 reveals that 37 percent of the variation of $\log$ percent cousin marriage is explained by Church exposure, while 64 percent is explained by the Carolingian Empire. These numbers would increase if we controlled for Islam in Sicily (where no-restrictions existed) vs. Eastern Orthodoxy in mainland southern Italy and population movements after the $15^{\text {th }}$ century in Spain. There Moriscos were forcefully relocated to Northwestern regions. Even though the sample contains only 69 regions (variation stemming only from 57 since Turkey did not experience Western Church exposure), the estimates are robust to the inclusion of the covariates- only when controlling for absolute latitude do they become insignificant in the case of regional Church exposure. The results are consistent with our hypothesis that the Carolingian Empire is a stronger predictor than Western Church exposure based on radiuses around bishoprics. 


\begin{tabular}{|c|c|c|c|c|c|c|c|c|c|c|c|c|c|c|}
\hline & \multicolumn{14}{|c|}{ Log $\%$ cousin marriage } \\
\hline & (1) & (2) & (3) & (4) & (5) & (6) & (7) & (8) & (9) & (10) & (11) & (12) & (13) & (14) \\
\hline W. Church exposure & $-0.274^{* * *}$ & $-0.101^{* *}$ & $-0.094^{* *}$ & -0.040 & $-0.099^{* *}$ & $-0.093^{* *}$ & $-0.095^{* *}$ & $-0.143^{* * *}$ & -0.003 & -0.008 & 0.017 & -0.003 & 0.003 & -0.046 \\
\hline$(\mathrm{N}: 69)$ & $(0.020)$ & $(0.045)$ & $(0.046)$ & $(0.038)$ & $(0.043)$ & $(0.046)$ & $(0.047)$ & $(0.042)$ & $(0.048)$ & $(0.045)$ & $(0.031)$ & $(0.048)$ & $(0.050)$ & $(0.044)$ \\
\hline$R^{2}$ & 0.750 & 0.847 & 0.848 & 0.895 & 0.876 & 0.849 & 0.848 & 0.882 & 0.868 & 0.898 & 0.916 & 0.868 & 0.870 & 0.897 \\
\hline $\begin{array}{l}\text { Carolingian empire } \\
\text { (N: 69) }\end{array}$ & $\begin{array}{l}-1.925^{* * *} \\
(0.195)\end{array}$ & $\begin{array}{c}-0.944^{* * *} \\
(0.155)\end{array}$ & $\begin{array}{l}-1.034^{* * *} \\
(0.177)\end{array}$ & $\begin{array}{l}-0.741^{* * *} \\
(0.178)\end{array}$ & $\begin{array}{c}-0.934^{* * *} \\
(0.173)\end{array}$ & $\begin{array}{l}-1.030^{* * *} \\
(0.177)\end{array}$ & $\begin{array}{c}-1.038^{* * *} \\
(0.182)\end{array}$ & $\begin{array}{c}-1.033^{* * *} \\
(0.151)\end{array}$ & $\begin{array}{c}-0.860^{* * *} \\
(0.186)\end{array}$ & $\begin{array}{l}-0.708^{* * *} \\
(0.185)\end{array}$ & $\begin{array}{l}-0.520^{* * *} \\
(0.176)\end{array}$ & $\begin{array}{c}-0.862^{* * *} \\
(0.187)\end{array}$ & $\begin{array}{c}-0.846^{* * *} \\
(0.193)\end{array}$ & $\begin{array}{l}-0.795^{* * *} \\
(0.142)\end{array}$ \\
\hline$R^{2}$ & 0.609 & 0.888 & 0.892 & 0.914 & 0.908 & 0.892 & 0.892 & 0.910 & 0.897 & 0.914 & 0.925 & 0.897 & 0.898 & 0.917 \\
\hline $\begin{array}{l}\text { Geographic baseline } \\
\text { w/o latitude }\end{array}$ & & & Yes & Yes & Yes & Yes & Yes & Yes & Yes & Yes & Yes & Yes & Yes & Yes \\
\hline Absolute latitude & & & & & & & & & Yes & Yes & Yes & Yes & Yes & Yes \\
\hline Further geographic controls & & & & Yes & & & & & & Yes & & & & \\
\hline Rye suit. \& oats suit. & & & & & Yes & & & & & & Yes & & & \\
\hline Roman roads & & & & & & Yes & & & & & & Yes & & \\
\hline Pop. dens 500AD & & & & & & & Yes & & & & & & Yes & \\
\hline Monastic presence & & & & & & & & Yes & & & & & & Yes \\
\hline Country FE & & Yes & Yes & Yes & Yes & Yes & Yes & Yes & Yes & Yes & Yes & Yes & Yes & Yes \\
\hline
\end{tabular}

Monastic presence

Table S4.6: Regional level OLS regression of log percent first cousin marriages on Western Church exposure (upper row) and exposure to the Carolingian Empire (lower row). Included are the regions of Spain, France, and Italy. Columns 2 to 12 control for country fixed effects. In Columns 3 to 7 the baseline set of geographic covariates without absolute latitude is added. Columns 8 to 12 contain the whole baseline set including absolute latitude. Columns 4 and 9 contain further geographic covariates (precipitation, temperature, elevation, and presence of river or lake); Columns 5 and 10 contain caloric suitability for oats and rye; Columns 6 and 11 control for Roman roads; Columns 7 and 12 contain estimates for population density in the year $500 \mathrm{CE}$; and Column 8 and 14 control for exposure to Cluniac, Cistercians, Premonstratensians, Franciscans, and Dominicans houses. Robust standard errors are reported in parentheses. ${ }^{*} P \leq 0.1,{ }^{* *} P \leq 0.05$, ${ }^{* * *} \mathrm{P} \leq 0.01$ (two-sided). 


\section{S5. Kinship intensity in Italian provinces and blood donations}

In Section S3, cross-country analyses demonstrated a robust association between kinship intensity and blood donations, an ecologically relevant observational measure capturing impersonal cooperation. Voluntary blood donations are lower in countries with higher kinship intensity. However, cross-country analysis has limitations. While we control for many covariates, we cannot be sure that some other variables at the country level bias the estimates. For example, marriage patterns are tightly linked to religion. This makes disentangling religious factors from marriage patterns difficult. Here, we focus solely on variation within Italy. For many decades, all of Italy experienced the same formal institutions and for many centuries the same religion. Yet, for a considerable duration in the medieval period, parts of Italy did not experience the Western Church's Marriage and Family Program (MFP). While the Western Church, supported by the Carolingian Empire, implemented and enforced marriage rules in northern and central Italy, Sicily was under Islamic rule and mainland southern Italy was governed by Byzantium and the Langobardic kingdoms. Thus, these mainland areas were either under the influence of the Eastern Church or - in the case of the Langobardic Kingdoms were not integrated into the Western Church's administration (see Section 2.3). Exploiting withincountry variation in Italy thus provides further evidence that kin-marriage patterns, and not some other omitted variable, impact altruistic behavior.

We proxy kinship intensity using first cousin marriages. Our data on cousin marriages is based on Church dispensations (54). ${ }^{56}$ Our dependent variable is blood donations (number of 16-ounce blood bags collected per 1000 inhabitants in 1995). It is taken from Guiso et al. (229). The data is based on AVIS (Italian association of voluntary blood donors), which collects 90 percent of the whole blood donations and 100 percent of anonymous blood donations in Italy. The within country analysis has the advantage that common national regulations and the fact that blood donations are organized by one single organization mitigate the possibility that geographic variation in blood donations reflect differences in infrastructure or quality standards. Figures S5.1 displays the regional variation in the percentage of first cousin marriages and blood donations, while Figure S5.2 is a scatter plot revealing a highly significant and quantitatively large relationship between cousin marriages and blood donations. When cousin marriage rates double, blood donations (per 1000 inhabitants) decrease by around $8 \approx 11.79 \cdot \ln (2)$ units (see Table S5.1, Column 1 ).

\footnotetext{
${ }^{56}$ This is the same data used for the European regional analysis for Italy. In this section, however, we use the more disaggregated provincial-level data.
} 


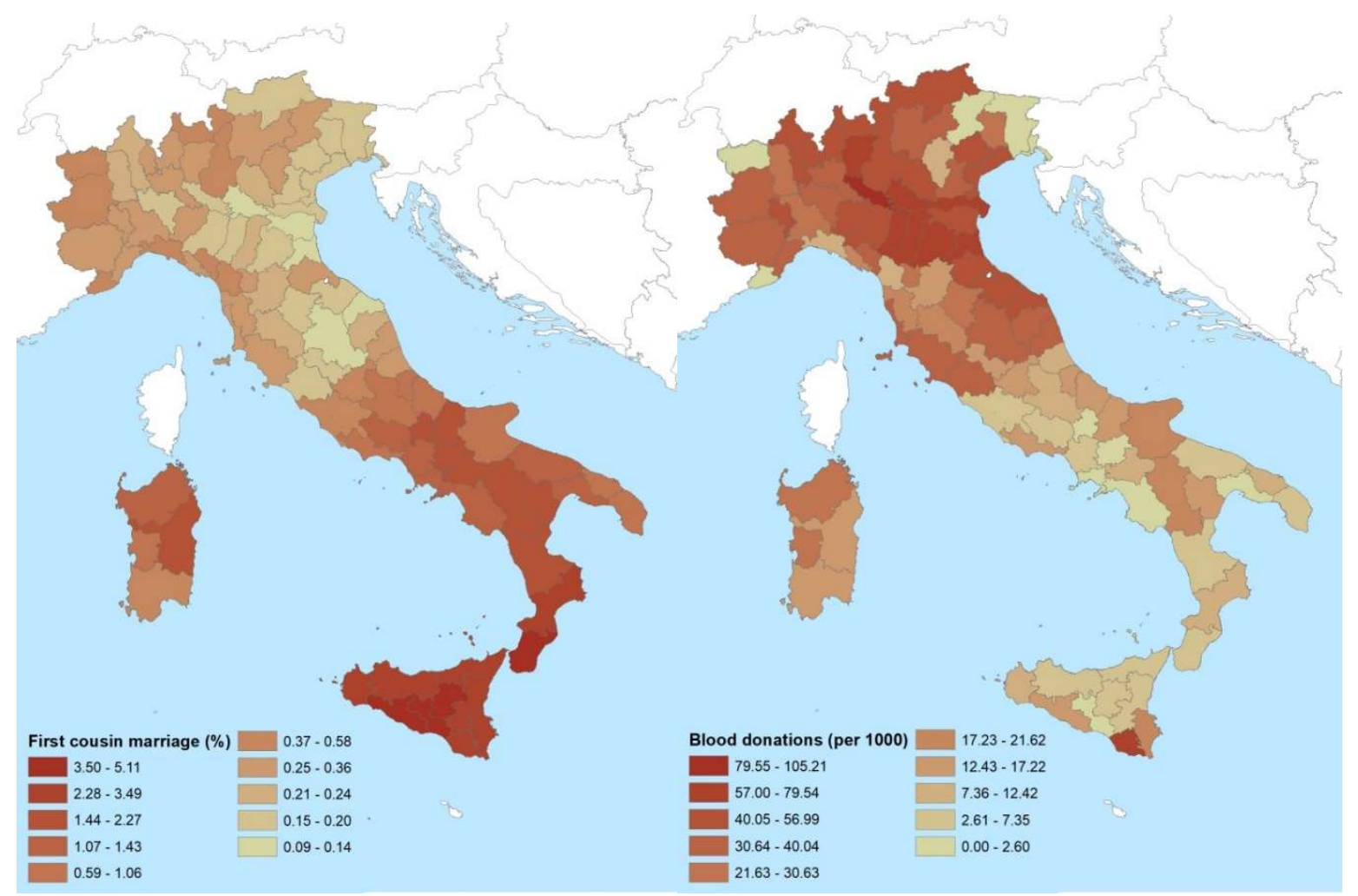

Figure S5.1 First cousin marriages percentage in the provinces of Italy (left figure) and blood donations (per 1000 inhabitants, right figures).

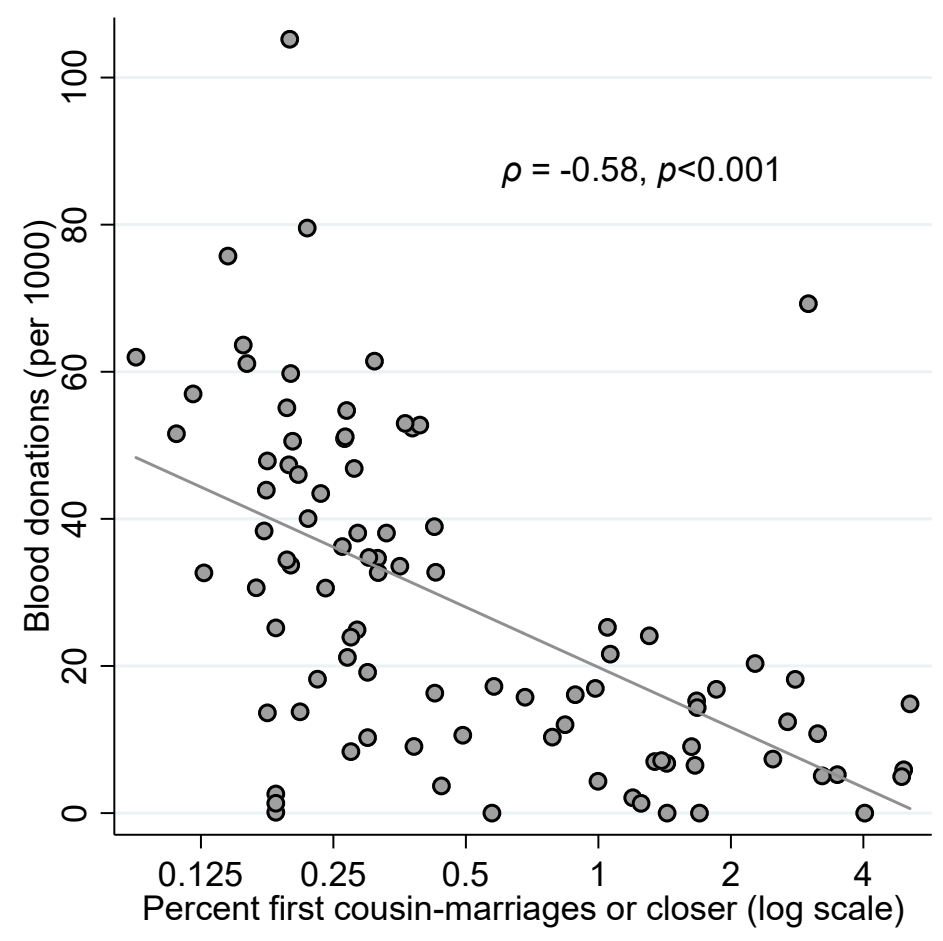

Figure S5.2: Percent cousin marriage (log scale) and blood donations (per 1,000 inhabitants) in the provinces of Italy. Spearman's $\rho$ and the associated significant level are reported. 
Table S5.1 presents the regression results. As in Section S4, we included baseline geographic controls for terrain ruggedness, distance to the coast, caloric suitability, and absolute latitude (Columns 2 to 8). ${ }^{57}$ To address the possibility that technological advancements surrounding rye and oats in medieval times bias our estimates, we again control for caloric suitability for oats and rye (Columns 3 to 4). Columns 4 and 5 contain a whole range of additional geographic control variables (elevation, slope, precipitation, and presence of rivers and lakes). In Column 5, we add average years of schooling (in the year 1981, based on (229)). Note that this might be "bad control", since education is probably also an outcome of intensive kinship systems and estimates might therefore become biased (175). Columns 6 and 7 contain fixed effects both for the Kingdom of Naples and Sicily. This allows us to rule out the possibility that we are capturing differences in political entities that existed from the $11^{\text {th }}$ century onwards. In Italy, the administrative divisions above the province consist of 19 regioni. Regioni are the more important units than provinces regarding administration and enforcement of formal institutions. Their autonomous power is specified in the Italian constitution. In Column 8, we include 19 fixed effects of the regioni, ruling out the possibility that our estimates are biased due to regional effects like differences in the quality of local institutions.

Column 1 of Table S5.1 presents the regression results without additional covariates as controls. The regression coefficients all go in the predicted direction and are both highly significant and robust to the introduction of the geographic covariates as well as education: they only vary between -10.99 and -13.68 in Columns 2 to 5 . The $R^{2}$ in Column 1 is fairly high: log percent first cousin marriage explains $32 \%$ of the variance. Adding an additional 12 variables (Column 5) does not even double the $R^{2}$. When adding fixed effects for the kingdom of Naples, the kingdom of Sicily (Columns 6 and 7), and the 19 Italian regioni (Column 8), the coefficients decrease. However, they are still sizeable, even though in the case of fixed effects for the Italian regioni the coefficients are significant only at the $10 \%$ level. The decrease is not surprising given that the regional fixed effects remove a lot of variation, and that the borders of the kingdoms of Naples and Sicily coincide with varying historical enforcement of the Church's MFP. For example, prior to the establishment of the Kingdoms of Naples and Sicily, those areas were exposed to only a weaker MFP compared to other areas of Italy at the time (Kingdom of Naples) or it was non-existent (Kingdom of Sicily).

\footnotetext{
${ }^{57}$ For a more in-depth discussion of the covariates that we include as controls, see Section S3, S4. For the details on the definitions and data sources, see Section S9.
} 


\begin{tabular}{|c|c|c|c|c|c|c|c|c|}
\hline & \multicolumn{7}{|c|}{ "Blood Donations (per 1000 inhabitants) } & \multirow[b]{2}{*}{ (8) } \\
\hline & (1) & (2) & (3) & (4) & (5) & (6) & (7) & \\
\hline $\begin{array}{l}\text { Log \% first cousin marriage } \\
\text { (or closer) }\end{array}$ & $\begin{array}{l}-11.79^{* * *} \\
(1.80)\end{array}$ & $\begin{array}{l}-11.05^{* * *} \\
(3.77)\end{array}$ & $\begin{array}{l}-12.80^{* * *} \\
(3.71)\end{array}$ & $\begin{array}{l}-12.09^{* * *} \\
(4.12)\end{array}$ & $\begin{array}{l}-13.68^{* * *} \\
(4.12)\end{array}$ & $\begin{array}{l}-8.19^{* *} \\
(4.04)\end{array}$ & $\begin{array}{l}-8.14^{* *} \\
(3.92)\end{array}$ & $\begin{array}{l}-6.38^{*} \\
(3.67)\end{array}$ \\
\hline Baseline controls & - & Yes & Yes & Yes & Yes & Yes & Yes & Yes \\
\hline Oats \& rye suitability & - & - & Yes & Yes & Yes & - & - & - \\
\hline Additional geographic controls & - & - & - & Yes & Yes & - & - & - \\
\hline Average years of schooling & - & - & - & - & Yes & - & Yes & Yes \\
\hline Kingdom of Naples and Sicily FE & - & - & - & - & - & Yes & Yes & - \\
\hline Region FE & - & - & - & - & - & - & - & Yes \\
\hline $\begin{array}{l}N \\
R^{2}\end{array}$ & $\begin{array}{l}92 \\
0.321\end{array}$ & $\begin{array}{l}92 \\
0.476\end{array}$ & $\begin{array}{l}92 \\
0.506\end{array}$ & $\begin{array}{l}92 \\
0.538\end{array}$ & $\begin{array}{l}92 \\
0.564\end{array}$ & $\begin{array}{l}92 \\
0.506\end{array}$ & $\begin{array}{l}92 \\
0.540\end{array}$ & $\begin{array}{l}92 \\
0.753\end{array}$ \\
\hline \multicolumn{9}{|c|}{$\begin{array}{l}\text { Table S5.1: Provincial-level OLS regression of blood donations (per } 1000 \text { inhabitants) on log percent first cousin marriages (o } \\
\text { closer). Columns } 2 \text { to } 9 \text { include the baseline set of geographic control variables (terrain ruggedness, distance to the coast } \\
\text { caloric suitability, and absolute latitude). In Columns } 3 \text { to } 5 \text {, caloric suitability for oats } \& \text { rye are added, and in Columns } 4 \text { an } \\
5 \text { include another set of geographic covariates (elevation, slope, precipitation, presence of river and lakes, and temperature) } \\
\text { Columns } 5,7 \text { and } 8 \text { control for average years of education (in the year } 1981 \text { ); Columns } 6 \text { and } 7 \text { for Kingdom of Naples an } \\
\text { Kingdom of Sicily fixed effects; and Column } 8 \text { for } 19 \text { region fixed effects. }{ }^{*} P \leq 0.1, * * P<0.05, * * * 01 \text { (two-sided). }\end{array}$} \\
\hline
\end{tabular}




\section{S6. Epidemiological approach: Children of immigrants in Europe}

We have established a strong association between kinship intensity and a long list of psychological and behavioral variables at the country and (European) regional level. The results also hold within Italy for blood donations, which is a more ecologically relevant measure. Regression analyses demonstrate that the results are robust to the inclusion of a long list of covariates. Yet, omitted factors at the country or regional level may bias the estimates. To get closer to establishing causality, we follow the epidemiological approach $(157,158)$ and restrict our analysis to the adult offspring of immigrants to Europe. We are interested in whether the kinship intensity of immigrants' origin country or ancestral ethnicity predicts their children's generalized trust, generalized fairness, conformity-obedience, and individualism-independence (using the same ESSbased psychological variables as in Section S4). Children of immigrants growing up in the same country face the same societal-level environment but differ in their cultural heritage. In principle, thus, this approach removes one possible source of bias in the estimates - bias due to societal-level factors such as formal institution, schooling, or infrastructure.

We conduct two related analyses. In Section S6.1, we investigate the impact of kinship intensity on the psychology of the children of immigrants, using the kinship intensity of the parents' country of origin. In Section S6.2, we focus on the ancestral ethnicity (instead of origin country), which allows us to exploit variation in kinship intensity within the country of origin. In both frameworks, we find that kinship intensity is negatively associated with generalized trust, fairness perceptions, and individualism, and positively so with conformity. These results generally hold when we include a rich set of covariates as controls.

Our approach addresses estimation biases that arise at the societal level of residence, but several other factors could potentially bias our estimates.

First, the children of immigrants are a selected sample. The degree of kinship intensity of the origin country may affect the type of individuals emigrating. It is not clear, though, in what direction a bias would go. Individuals willing to emigrate from intensive kinship countries may place less weight on their cultural inheritance compared to the ones staying, since relocating to European countries involves joining a society with extensive kinship systems and often leaving the extended family behind. This may bias the estimates downward. On the other hand, incentives to relocate may be higher for poorer individuals (which may correlate with intensive kinship systems). It is thus not clear how the results generalize, and they should therefore be viewed as pertaining to this selected sample.

Second, children of immigrants may experience differential discrimination, which in turn may impact trust. To mitigate this possibility, in several specifications we control for whether individuals feel discriminated against (in addition to other individual factors like labor market participation and level of education).

Third, depending on the KII of the originating country, immigrants may differentially select themselves into specific regions or differentially prefer cities over villages. In the robustness checks, we control for residenceregion fixed effects instead of residence-country fixed effects. This approach exploits within-region variation, which is variation among children of immigrants that thus faced the same regional customs and institutions. In addition, we control for city size. The results are robust to these control variables. 
Fourth, other characteristics of the immigrants' origin countries may determine both (vertically transmitted) kinship intensity in the parent's country of origin and the children of immigrants' psychological variables. That is, the vertically transmitted culture we capture may be only indirectly related to kinship intensity. For example, political instability, weak institutions, and geographical characteristics of the immigrants' originating country may impact both culturally transmitted trust and intensive kinship of the originating country. Several features of our approach mitigate this possibility. First, the KII is based on the Ethnographic Atlas (EA), which aims to capture ethnicities' characteristics before European contact (or industrialization). Similarly, Church exposure is likewise a "deep" historical variable. As such, it is unlikely that our estimates are biased by short- or medium-term characteristics of the originating country like political instability, poor rule of law, or a legacy of colonialization. In addition, we control for the baseline set of geographic variables of the originating country. In Section S6.2, we go a step further and focus on the kinship intensity of the parents' ancestral ethnicity (instead of origin country). This allows us to control for other characteristics of ethnicity and for origin country fixed effects. This approach thus rules out estimation bias due to origin country-level factors. Moreover, we control for other ethnicity characteristics like subsistence, judicial hierarchy, and settlement complexity. In this way, we mitigate the possibility that other ethnicity-level factors bias the estimates.

The matching for the analysis in Section S6.2 is done based on the first and second language spoken in the home of an immigrant's child. We only include individuals who speak a language different from one of the native languages of the residence country. This yields a selected sample that only includes individuals who did not adopt the common language of the resident country; the estimates are therefore likely upward biased and should not be looked at in isolation. Rather, the analysis is intended to demonstrate that intensive kinship systems, and not other origin country-level or ethnicity-level factors, are an important determinant of the psychology of second generation immigrants (in the more selected sample).

\section{S6.1. Kinship intensity of the parents' country of origin and psychological outcomes}

Our psychological variables come from the European Social Survey (ESS). The ESS covers 36 countries, most of which are located in Europe. ${ }^{58}$ It contains information on the origin country of respondents' parents. This allows us to match the ESS respondents to our measures of kinship intensity and Church exposure based on the originating countries of the respondents' mothers. The ESS-based psychological variables are the same as in Section S4: generalized trust, generalized fairness, conformity-obedience, and individualismindependence. Following the literature, we restrict the sample to those individuals who were born in their current country of residence and have mothers who were born in a different country. The explanatory variables are the KII, log percent cousin marriage, and Church exposure of the mother's originating country. (As robustness checks, we show that the results hold when focusing on the father's or when averaging across both parents' originating countries.)

\footnotetext{
58 The ESS also includes data on Israel and Turkey.
} 


\begin{tabular}{|c|c|c|c|c|c|c|c|c|}
\hline & \multicolumn{6}{|c|}{ Full sample } & \multicolumn{2}{|c|}{ Non-MFP sample } \\
\hline & $(1)$ & $(2)$ & (3) & (4) & (5) & (6) & (7) & (8) \\
\hline & \multicolumn{8}{|c|}{ Panel 1: Generalized trust (z-scores) } \\
\hline KII (mother's o. country) & $-0.076^{* * *}$ & $-0.097^{* * *}$ & $-0.087^{* * *}$ & $-0.079^{* * *}$ & $-0.068^{* * *}$ & $-0.067^{* * *}$ & $-0.113^{* * *}$ & $-0.086^{*}$ \\
\hline$\left(N_{\text {Full-sample }}=12,798, N_{\text {Non-MFP }}=3,350\right)$ & $(0.013)$ & $(0.014)$ & $(0.019)$ & $(0.014)$ & $(0.013)$ & $(0.017)$ & $(0.040)$ & $(0.044)$ \\
\hline$R^{2}$ & 0.096 & 0.098 & 0.098 & 0.121 & 0.122 & 0.122 & 0.069 & 0.101 \\
\hline Log $\%$ cousin m. (mother's o. country) & $-0.060^{* * *}$ & $-0.073^{* * *}$ & $-0.078^{* * *}$ & $-0.058^{* * *}$ & $-0.050^{* * *}$ & $-0.056^{* *}$ & -0.052 & -0.043 \\
\hline$\left(N_{\text {Full sample }}=7,508, N_{\text {Non-MFP }}=2,959\right)$ & $(0.008)$ & $(0.012)$ & $(0.021)$ & $(0.010)$ & $(0.011)$ & $(0.021)$ & $(0.034)$ & $(0.032)$ \\
\hline$R^{2}$ & 0.098 & 0.101 & 0.101 & 0.126 & 0.127 & 0.128 & 0.071 & 0.102 \\
\hline \multirow[t]{2}{*}{ W. Church exp. (mother's o. country - in 100 yrs.) } & $0.017^{* * *}$ & $0.019^{* * *}$ & 0.006 & $0.014^{* *}$ & 0.009 & 0.002 & & \\
\hline & $(0.006)$ & $(0.006)$ & $(0.006)$ & $(0.005)$ & $(0.006)$ & $(0.006)$ & & \\
\hline E. Church exp. (mother's o. country - in 100 yrs.) & 0.016 & $0.028^{*}$ & 0.000 & 0.021 & 0.016 & 0.001 & & \\
\hline$(N=12,415)$ & $(0.014)$ & $(0.014)$ & $(0.014)$ & $(0.013)$ & $(0.014)$ & $(0.014)$ & & \\
\hline \multirow[t]{2}{*}{$R^{2}$} & 0.094 & 0.096 & 0.097 & 0.120 & 0.122 & 0.122 & & \\
\hline & \multicolumn{8}{|c|}{ Panel 2: Generalized fairness (z-scores) } \\
\hline KII (mother's o. country) & $-0.070^{* * *}$ & $-0.079^{* * *}$ & $-0.061^{* * *}$ & $-0.060^{* * *}$ & $-0.042^{* * *}$ & $-0.039^{* *}$ & $-0.109^{*}$ & -0.080 \\
\hline$\left(N_{\text {Full sample }}=12,739, N_{\text {Non-MFP }}=3,335\right)$ & $(0.009)$ & $(0.013)$ & $(0.021)$ & $(0.013)$ & $(0.015)$ & $(0.017)$ & $(0.063)$ & $(0.066)$ \\
\hline$R^{2}$ & 0.082 & 0.084 & 0.084 & 0.106 & 0.108 & 0.108 & 0.067 & 0.094 \\
\hline Log $\%$ cousin m. (mother's o. country) & $-0.061^{* * *}$ & $-0.078^{* * *}$ & $-0.074^{* * *}$ & $-0.062^{* * *}$ & $-0.051^{* * *}$ & $-0.051^{* *}$ & $-0.097^{* * *}$ & $-0.085^{* *}$ \\
\hline$\left(N_{\text {Full sample }}=7,484, N_{\text {Non-MFP }}=2,949\right)$ & $(0.007)$ & $(0.009)$ & $(0.021)$ & $(0.008)$ & $(0.010)$ & $(0.023)$ & $(0.031)$ & $(0.033)$ \\
\hline$R^{2}$ & 0.088 & 0.089 & 0.090 & 0.114 & 0.115 & 0.116 & 0.070 & 0.097 \\
\hline \multirow[t]{2}{*}{ W. Church exp. (mother's o. country - in 100 yrs.) } & $0.016^{* *}$ & $0.015^{* *}$ & -0.002 & 0.009 & 0.002 & -0.007 & & \\
\hline & $(0.006)$ & $(0.006)$ & $(0.006)$ & $(0.006)$ & $(0.007)$ & $(0.006)$ & & \\
\hline E. Church exp. (mother's o. country - in 100 yrs.) & 0.005 & 0.006 & $-0.030^{* *}$ & -0.001 & -0.009 & $-0.028^{* *}$ & & \\
\hline$(N=12,358)$ & $(0.010)$ & $(0.011)$ & $(0.013)$ & $(0.011)$ & $(0.011)$ & $(0.013)$ & & \\
\hline$R^{2}$ & 0.081 & 0.083 & 0.085 & 0.106 & 0.108 & 0.109 & & \\
\hline & \multicolumn{8}{|c|}{ Panel 3: Conformity-obedience (z-scores) } \\
\hline KII (mother's o. country) & $0.117^{* * *}$ & $0.127^{* * *}$ & $0.072^{* *}$ & $0.113^{* * *}$ & $0.066^{* * *}$ & 0.044 & $0.071^{*}$ & 0.057 \\
\hline$\left(N_{\text {Full sample }}=11,694, N_{\text {Non-MFP }}=3,044\right)$ & $(0.020)$ & $(0.030)$ & $(0.035)$ & $(0.028)$ & $(0.020)$ & $(0.026)$ & $(0.037)$ & $(0.035)$ \\
\hline$R^{2}$ & 0.134 & 0.136 & 0.137 & 0.159 & 0.219 & 0.219 & 0.106 & 0.129 \\
\hline Log $\%$ cousin m. (mother's o. country) & $0.064^{* * *}$ & $0.092^{* * *}$ & $0.076^{* * *}$ & $0.081^{* * *}$ & $0.051^{* * *}$ & $0.055^{* * *}$ & $0.121^{* * *}$ & $0.106^{* * *}$ \\
\hline$\left(N_{\text {Full sample }}=6,875, N_{\text {Non-MFP }}=2,679\right)$ & $(0.017)$ & $(0.016)$ & $(0.018)$ & $(0.017)$ & $(0.011)$ & $(0.017)$ & $(0.025)$ & $(0.023)$ \\
\hline 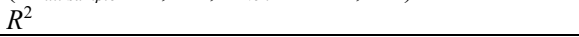 & 0.126 & 0.131 & 0.131 & 0.158 & 0.234 & 0.234 & 0.094 & 0.121 \\
\hline \multirow[t]{2}{*}{ W. Church exp. (mother's o. country - in 100 yrs.) } & $-0.026^{* * *}$ & $-0.028^{* * *}$ & -0.003 & $-0.024^{* * *}$ & $-0.012^{* * *}$ & -0.002 & & \\
\hline & $(0.008)$ & $(0.008)$ & $(0.009)$ & $(0.008)$ & $(0.004)$ & $(0.006)$ & & \\
\hline E. Church exp. (mother's o. country - in 100 yrs.) & $-0.051^{* *}$ & $-0.056^{* * *}$ & -0.005 & $-0.050^{* * *}$ & $-0.030^{* * *}$ & -0.011 & & \\
\hline$(N=11347)$ & $(0.023)$ & $(0.011)$ & $(0.015)$ & $(0.010)$ & $(0.008)$ & $(0.013)$ & & \\
\hline \multirow[t]{2}{*}{$R^{2}$} & 0.131 & 0.133 & 0.136 & 0.157 & 0.218 & 0.219 & & \\
\hline & \multicolumn{8}{|c|}{ Panel 4: Individualism-independence (z-scores) } \\
\hline KII (mother's o. country) & $-0.056^{*}$ & $-0.068^{* *}$ & -0.049 & $-0.054^{* *}$ & -0.022 & -0.025 & -0.070 & -0.059 \\
\hline$\left(N_{\text {Full sample }}=11,694, N_{\text {Non-MFP }}=3,044\right)$ & $(0.029)$ & $(0.028)$ & $(0.032)$ & $(0.023)$ & $(0.021)$ & $(0.024)$ & $(0.054)$ & $(0.048)$ \\
\hline$R^{2}$ & 0.058 & 0.058 & 0.059 & 0.083 & 0.097 & 0.097 & 0.060 & 0.082 \\
\hline Log $\%$ cousin m. (mother's o. country) & $-0.038^{* *}$ & $-0.063^{* * *}$ & $-0.065^{* * *}$ & $-0.053^{* * *}$ & $-0.032^{* *}$ & $-0.045^{*}$ & $-0.071^{*}$ & -0.057 \\
\hline$\left(N_{\text {Full sample }}=6,875, N_{\text {Non-MFP }}=2,679\right)$ & $(0.016)$ & $(0.013)$ & $(0.021)$ & $(0.012)$ & $(0.012)$ & $(0.023)$ & $(0.038)$ & $(0.036)$ \\
\hline$R^{2}$ & 0.056 & 0.059 & 0.060 & 0.084 & 0.100 & 0.101 & 0.065 & 0.090 \\
\hline W. Church exp. (mother's o. country - in 100 yrs.) & 0.014 & $0.018^{* *}$ & 0.007 & $0.015^{* *}$ & 0.006 & 0.005 & & \\
\hline & $(0.009)$ & $(0.007)$ & $(0.008)$ & $(0.006)$ & $(0.005)$ & $(0.006)$ & & \\
\hline E. Church exp. (mother's o. country - in 100 yrs.) & 0.023 & $0.031^{* *}$ & 0.006 & $0.025^{* *}$ & 0.015 & 0.013 & & \\
\hline$(N=11,347)$ & $(0.019)$ & $(0.012)$ & $(0.018)$ & $(0.011)$ & $(0.012)$ & $(0.015)$ & & \\
\hline$R^{2}$ & 0.058 & 0.060 & 0.060 & 0.085 & 0.098 & 0.099 & & \\
\hline Basic individual controls & Yes & Yes & Yes & Yes & Yes & Yes & Yes & Yes \\
\hline Resident country \& wave FE & Yes & Yes & Yes & Yes & Yes & Yes & Yes & Yes \\
\hline Mother's o. country geographic baseline & - & Yes & Yes & Yes & Yes & Yes & - & Yes \\
\hline Further individual controls & - & - & - & Yes & Yes & Yes & - & Yes \\
\hline Religious denom. \& religiousness & - & - & - & - & Yes & Yes & - & - \\
\hline Origin continent FE & - & - & Yes & - & - & Yes & - & - \\
\hline
\end{tabular}

Table S6.1: OLS regressions of our five ESS-based dependent variables on KII, log percent cousin marriage, and Western and Eastern Church exposure (in 100 years) in the origin country of the respondent's mother. Each column contains results from 15 separate regressions. Each observation is a respondent with an immigrant mother. Columns 7 and 8 report results for the sub-sample where all origin countries that experienced more than 120 years of either Churches' MFP are excluded, and $N_{\text {Non-MFP }}$ denotes the size of this sub-sample. All regressions control for standard demographic variables (age, age squared, gender), as well as ESS wave and residence country fixed-effects. Columns 2-6 and 8 add the baseline set of origin country controls (absolute latitude, ruggedness, caloric suitability for agriculture, mean distance to waterways). Columns 4-6 and 8 include further individual indicator variables (marriage status, feeling discriminated against, secondary education, tertiary education, unemployed and searching for a job, and inactivity in the labor market). Columns 5 and 6 include the respondent's religious denomination and religiousness. Columns 3 and 6 contain origin continent fixed effects. Robust standard errors clustered at the resident country level are reported in parentheses. * $P \leq 0.1,{ }^{* *} P \leq 0.05$, *** $\mathrm{P} \leq 0.01$ (twosided). 
Table S6.1 reports the regression results. Each panel presents on a different dependent variable, and for each dependent variable we report three regressions each with different explanatory variables: (i) KII, (ii) $\log$ percent cousin marriage, and (iii) Eastern and Western Church exposure. All regressions include basic individual controls (age, age squared, and gender), resident country fixed effects, and ESS-wave fixed effects. In Column 2, our baseline set of geographic control variables (of mother's origin country) are added (absolute latitude, ruggedness, caloric suitability for agriculture, and mean distance to waterways). This baseline set is the same as in the cross-country analysis. Columns 3 and 6 contain fixed effects for the continent of the origin country of the mother. In Column 4 we add further individual-level controls, which are potentially endogenous (indicator variables for being married, feeling discriminated against, having secondary education, having tertiary education, being unemployed and searching for a job, and being inactive in the labor market). These variables that might themselves be the outcome of kinship intensity might therefore be considered as "bad controls"(175). For example, Alesina and Giuliano $(135,136)$ demonstrate a strong association between nuclear family ties and labor market participation. That is, educational attainment may itself depend on the strength of kinship intensity. In Column 5 and 6, we add indicator variables for individuals' religious denominations (Catholic, Protestant, Eastern Orthodox, other Christian, Jewish, Muslim, other non-Christian, no denomination is the excluded category) and religiousness (measured on an 11-point scale from 0 to 10). Religious adherence is an important control. Although it exhibits a high correlation with the measures of kinship intensity due to the Medieval Churches' marriage regulations, it allows us to demonstrate that religious adherence is not driving our estimates.

We tested whether the results hold if we exclude all countries where a substantial fraction of ancestors experienced the Churches' MFP (the Non-MFP sample). This is an important robustness check since it allows us to investigate whether the relationship between kinship intensity and the psychological outcome variables holds more generally or whether it is driven by the European experience alone. If it holds, this mitigates the concern that the relationship we find between Church exposure and the psychological variables are driven by a omitted factor specific to Europe. Paralleling the cross-country regression analysis in Section S3, we excluded all respondents whose mothers are from a country where the average person's ancestors were exposed to either Church by more than four generations (that is, 120 years). This excludes all European countries, Australia, New Zealand, South Africa and almost all countries in the Americas except Guatemala, Jamaica, Trinidad and Tobago, Peru and Haiti. Columns 7 and 8 report the regression results for this nonMFP sub-sample. In Column 8 , the baseline set of origin country geographic variables and individual covariates are added.

The results reveal a consistent association between our two measures of kinship intensity and Church exposure on the one hand and our psychological variables on the other. For example, a one-standard-deviation increase in the KII is associated with a significant decrease in generalized trust and fairness (of about 0.07 standard deviations, Column 1), a significant increase in conformity-obedience (of about 0.12 standard deviations, Column 1) and a weakly significant decrease in individualism-independence (of about 0.6 standard deviations, Column 1). As expected, the coefficients decrease when we add (potentially endogenous) individual controls like education, religiousness, religious denomination or labor market participation. 
However, most coefficients remain significant. When adding continent fixed effects, the coefficients in some specifications become insignificant. Unsurprisingly, this is particularly the case for Church exposure, where there is less within-continent variation. In the next Section S6.2, we demonstrate that the association between the KII of the origin ethnicity and the psychological variables hold even when we control for origin country fixed effects. This suggests that continent fixed effects are not a major source of concern. Surprisingly, we find that the coefficients of Eastern and Western Church exposure are similar in magnitude. Based on our hypothesis and the cross-country evidence, we expected larger coefficients for Western Church exposure. This may be because the children-of-immigrants sample is a self-selected one. In addition, the standard errors for the coefficient of Eastern Church exposure are larger, reflecting more uncertainty in the point estimates.

In the non-MFP sub-sample, the associations between KII and the psychological variables consistently have the expected sign. Compared to the full sample the coefficients for generalized trust and fairness are larger in magnitude and, in the case of generalized trust, highly significant. The associations of log percent cousin marriage with generalized fairness, conformity-obedience, and individualism-independence likewise reveal significant associations that are larger magnitudes compared to the full sample. The only exception is individualism-independence, where this association is not significant when controlling for potentially endogenous individual effects like education. The regressions based on this sub-sample thus support the hypothesis that kinship intensity - independent of the European experience - is associated with psychological outcomes.

\section{Robustness Checks}

\section{i. Robustness check: Father's and both parents' country of origin}

The sample used in the analysis reported above in Table S6.1 comprised individuals whose mothers had immigrated. Focusing on the mother's origin country follows the existing literature. Here, we demonstrate that the results hold in the sample consisting of individuals whose fathers were born in a different country by using indicators from the father's country of birth as the explanatory variables and covariates. We also demonstrate that the results hold in the sample consisting of individuals who have at least one parent born in a different country by taking the average indicator across the two parents' origin countries. The results look similar (see Table S6.2 and S6.3). 


\begin{tabular}{|c|c|c|c|c|c|c|c|c|}
\hline & \multicolumn{2}{|c|}{ Gen. trust } & \multicolumn{2}{|c|}{ Gen. fairness } & \multicolumn{2}{|c|}{$\begin{array}{l}\text { Conformity- } \\
\text { obedience }\end{array}$} & \multicolumn{2}{|c|}{$\begin{array}{l}\text { Individualism- } \\
\text { independence }\end{array}$} \\
\hline & (1) & (2) & (3) & (4) & (5) & (6) & (7) & $(8)$ \\
\hline KII (father's o. country) & $\begin{array}{c}-0.076^{* * *} \\
(0.021)\end{array}$ & $\begin{array}{l}-0.051^{* *} \\
(0.022)\end{array}$ & $\begin{array}{c}-0.068^{* * *} \\
(0.022)\end{array}$ & $\begin{array}{l}-0.039 \\
(0.027)\end{array}$ & $\begin{array}{l}0.088^{* *} \\
(0.033)\end{array}$ & $\begin{array}{c}0.023 \\
(0.023)\end{array}$ & $\begin{array}{l}-0.077^{* *} \\
(0.030)\end{array}$ & $\begin{array}{l}-0.035 \\
(0.022)\end{array}$ \\
\hline$N$ & 13597 & 13597 & 13516 & 13516 & 12424 & 12424 & 12424 & 12424 \\
\hline$R^{2}$ & 0.095 & 0.118 & 0.082 & 0.101 & 0.134 & 0.216 & 0.049 & 0.091 \\
\hline $\begin{array}{l}\text { Log \% cousin marriage } \\
\text { (father's o. country) }\end{array}$ & $\begin{array}{c}-0.060^{* * *} \\
(0.016)\end{array}$ & $\begin{array}{l}-0.044^{* *} \\
(0.016)\end{array}$ & $\begin{array}{c}-0.058^{* * *} \\
(0.021)\end{array}$ & $\begin{array}{l}-0.038 \\
(0.023)\end{array}$ & $\begin{array}{l}0.056^{* *} \\
(0.022)\end{array}$ & $\begin{array}{c}0.012 \\
(0.012)\end{array}$ & $\begin{array}{l}-0.036^{* *} \\
(0.017)\end{array}$ & $\begin{array}{l}-0.008 \\
(0.015)\end{array}$ \\
\hline$N$ & 7946 & 7946 & 7923 & 7923 & 7291 & 7291 & 7291 & 7291 \\
\hline$R^{2}$ & 0.101 & 0.125 & 0.091 & 0.111 & 0.136 & 0.238 & 0.052 & 0.100 \\
\hline $\begin{array}{l}\text { W. Church exp. (father's o. country) } \\
\text { (in } 100 \text { yrs.) }\end{array}$ & $\begin{array}{l}0.021^{* * *} \\
(0.006)\end{array}$ & $\begin{array}{l}0.014^{* *} \\
(0.006)\end{array}$ & $\begin{array}{l}0.021^{* *} \\
(0.009)\end{array}$ & $\begin{array}{c}0.011 \\
(0.010)\end{array}$ & $\begin{array}{c}-0.027^{* *} \\
(0.012)\end{array}$ & $\begin{array}{l}-0.008 \\
(0.009)\end{array}$ & $\begin{array}{l}0.022^{* *} \\
(0.010)\end{array}$ & $\begin{array}{c}0.011 \\
(0.008)\end{array}$ \\
\hline $\begin{array}{l}\text { E. Church exp. (father's o. country) } \\
\text { (in } 100 \text { yrs.) }\end{array}$ & $\begin{array}{l}0.036^{* * *} \\
(0.010)\end{array}$ & $\begin{array}{l}0.028^{* *} \\
(0.010)\end{array}$ & $\begin{array}{c}0.019 \\
(0.015)\end{array}$ & $\begin{array}{c}0.010 \\
(0.016)\end{array}$ & $\begin{array}{c}-0.068^{* * *} \\
(0.014)\end{array}$ & $\begin{array}{l}-0.035^{* * *} \\
(0.011)\end{array}$ & $\begin{array}{l}0.040^{* * *} \\
(0.011)\end{array}$ & $\begin{array}{l}0.020^{* *} \\
(0.010)\end{array}$ \\
\hline$N$ & 13190 & 13190 & 13112 & 13112 & 12052 & 12052 & 12052 & 12052 \\
\hline$R^{2}$ & 0.095 & 0.119 & 0.082 & 0.102 & 0.136 & 0.219 & 0.050 & 0.092 \\
\hline Basic individual controls & Yes & Yes & Yes & Yes & Yes & Yes & Yes & Yes \\
\hline Resident country \& wave FE & Yes & Yes & Yes & Yes & Yes & Yes & Yes & Yes \\
\hline Father's o. country geo. baseline & Yes & Yes & Yes & Yes & Yes & Yes & Yes & Yes \\
\hline Further individual controls & - & Yes & - & Yes & - & Yes & - & Yes \\
\hline Religious denomination \& religiousness & - & Yes & - & Yes & - & Yes & - & Yes \\
\hline
\end{tabular}

Table S6.2: OLS regression of the ESS-based psychological variables on KII, log percent cousin marriage, and Western and Eastern Church exposure (in 100 years) of the origin country of the respondent's father. Each observation is the child of an immigrant father. All regressions control for basic individual controls (age, age-squared, gender), wave and country of residence fixed effects, and the baseline set of father's origin country-level controls (absolute latitude, ruggedness, caloric suitability for agriculture, and mean distance to waterways). In addition, all even numbered columns include further individual indicator variables (marriage status, feeling discriminated against, secondary education, tertiary education, unemployed and searching for a job, and inactivity in the labor market), religious denominations and religiousness. Robust standard errors clustered at the resident country level are reported in parentheses. * $P \leq 0.1, * * P \leq 0.05, * * * P \leq 0.01$ (two-sided).

\begin{tabular}{|c|c|c|c|c|c|c|c|c|}
\hline & \multicolumn{2}{|c|}{ Gen. trust } & \multicolumn{2}{|c|}{ Gen. fairness } & \multicolumn{2}{|c|}{$\begin{array}{c}\text { Conformity- } \\
\text { obedience }\end{array}$} & \multicolumn{2}{|c|}{$\begin{array}{l}\text { Individualism- } \\
\text { independence }\end{array}$} \\
\hline & (1) & (2) & (3) & (4) & (5) & (6) & (7) & (8) \\
\hline KII (av. of parents' countries) & $\begin{array}{c}-0.119^{* * *} \\
(0.017)\end{array}$ & $\begin{array}{c}-0.084^{* * *} \\
(0.019)\end{array}$ & $\begin{array}{c}-0.100^{* * *} \\
(0.019)\end{array}$ & $\begin{array}{l}-0.063^{* *} \\
(0.027)\end{array}$ & $\begin{array}{l}0.146^{* * *} \\
(0.045)\end{array}$ & $\begin{array}{l}0.066^{* *} \\
(0.030)\end{array}$ & $\begin{array}{c}-0.098^{* *} \\
(0.037)\end{array}$ & $\begin{array}{l}-0.043 \\
(0.027)\end{array}$ \\
\hline$N$ & 19222 & 19222 & 19120 & 19120 & 17608 & 17608 & 17608 & 17608 \\
\hline$R^{2}$ & 0.103 & 0.127 & 0.090 & 0.111 & 0.148 & 0.222 & 0.055 & 0.092 \\
\hline $\begin{array}{l}\text { Log \% cousin marriage } \\
\text { (av. of parents' countries) }\end{array}$ & $\begin{array}{c}-0.052^{* *} \\
(0.019)\end{array}$ & $\begin{array}{c}-0.039^{* *} \\
(0.018)\end{array}$ & $\begin{array}{l}-0.058^{* *} \\
(0.022)\end{array}$ & $\begin{array}{l}-0.044^{*} \\
(0.023)\end{array}$ & $\begin{array}{l}0.039^{*} \\
(0.023)\end{array}$ & $\begin{array}{c}0.009 \\
(0.013)\end{array}$ & $\begin{array}{l}-0.013 \\
(0.023)\end{array}$ & $\begin{array}{c}0.009 \\
(0.016)\end{array}$ \\
\hline$N$ & 9096 & 9096 & 9076 & 9076 & 8327 & 8327 & 8327 & 8327 \\
\hline$R^{2}$ & 0.092 & 0.119 & 0.076 & 0.099 & 0.124 & 0.225 & 0.045 & 0.088 \\
\hline $\begin{array}{l}\text { W. Church exp. (av. of parents' countries) } \\
\text { (in } 100 \text { yrs.) }\end{array}$ & $\begin{array}{l}0.026^{* * *} \\
(0.006)\end{array}$ & $\begin{array}{l}0.014^{*} \\
(0.007)\end{array}$ & $\begin{array}{l}0.021^{* *} \\
(0.009)\end{array}$ & $\begin{array}{c}0.009 \\
(0.010)\end{array}$ & $\begin{array}{c}-0.039^{* * *} \\
(0.011)\end{array}$ & $\begin{array}{l}-0.015^{*} \\
(0.008)\end{array}$ & $\begin{array}{c}0.031^{* * *} \\
(0.010)\end{array}$ & $\begin{array}{l}0.016^{*} \\
(0.009)\end{array}$ \\
\hline $\begin{array}{l}\text { E. Church exp. (av. of parents' countries) } \\
\text { (in } 100 \text { yrs.) }\end{array}$ & $\begin{array}{l}0.034^{* *} \\
(0.014)\end{array}$ & $\begin{array}{c}0.022 \\
(0.015)\end{array}$ & $\begin{array}{c}0.012 \\
(0.014)\end{array}$ & $\begin{array}{c}0.000 \\
(0.015)\end{array}$ & $\begin{array}{c}-0.071^{* * *} \\
(0.015)\end{array}$ & $\begin{array}{c}-0.037^{* * *} \\
(0.011)\end{array}$ & $\begin{array}{c}0.050^{* * *} \\
(0.014)\end{array}$ & $\begin{array}{l}0.031^{* *} \\
(0.013)\end{array}$ \\
\hline$N$ & 18696 & 18696 & 18597 & 18597 & 17129 & 17129 & 17129 & 17129 \\
\hline$R^{2}$ & 0.103 & 0.127 & 0.090 & 0.111 & 0.149 & 0.223 & 0.057 & 0.094 \\
\hline Basic individual controls & Yes & Yes & Yes & Yes & Yes & Yes & Yes & Yes \\
\hline Resident country \& wave FE & Yes & Yes & Yes & Yes & Yes & Yes & Yes & Yes \\
\hline Fa. \& mo. o. country geo. baseline & Yes & Yes & Yes & Yes & Yes & Yes & Yes & Yes \\
\hline Further individual controls & - & Yes & - & Yes & - & Yes & - & Yes \\
\hline Religious denomination \& religiousness & - & Yes & - & Yes & - & Yes & - & Yes \\
\hline $\begin{array}{l}\text { Table S6.3: OLS regression of the ESS-1 } \\
\text { Church exposure (in } 100 \text { years) of both pa } \\
\text { control for basic individual controls (age, } \\
\text { controls averaged over the mother's and f } \\
\text { to waterways). In addition, all even numb }\end{array}$ & psyc & $\begin{array}{l}\text { cal va } \\
\text { nties. } \\
\text { nder), } \\
\text { ntries }\end{array}$ & 4 & $\begin{array}{l}\text { e KII, } \\
\text { ne chil } \\
\text { resid } \\
\text { ggedn }\end{array}$ & eff & $\begin{array}{l}\text { narria } \\
\text { imm } \\
\text { d the }\end{array}$ & $\begin{array}{l}\text { et of } \\
\text { and }\end{array}$ & $\begin{array}{l}\text { Eastern } \\
\text { ression } \\
\text { try-leve } \\
\text { distance } \\
\text { against }\end{array}$ \\
\hline
\end{tabular}




\section{ii. Robustness check: Two-way clustering}

The previous analysis (Table S6.1) followed the literature and clustered standard errors at the level of the residence country. Here we demonstrate that the results do not change much when we use two-way clustering (230) on both the residence country and the mother's origin country. (The results are also similar when we use three-way clustering in the sample that contains both mother's and father's origin country - available upon request.)

\begin{tabular}{|c|c|c|c|c|c|c|c|c|}
\hline & \multicolumn{2}{|c|}{ Gen. trust } & \multicolumn{2}{|c|}{ Gen. fairness } & \multicolumn{2}{|c|}{$\begin{array}{l}\text { Conformity- } \\
\text { obedience }\end{array}$} & \multicolumn{2}{|c|}{$\begin{array}{l}\text { Individualism- } \\
\text { independence }\end{array}$} \\
\hline & (1) & (2) & (3) & (4) & (5) & (6) & (7) & (8) \\
\hline $\begin{array}{l}\text { KII } \\
\text { (mother's o. country) }\end{array}$ & $\begin{array}{c}-0.097^{* * *} \\
(0.022)\end{array}$ & $\begin{array}{c}-0.068^{* * *} \\
(0.019)\end{array}$ & $\begin{array}{c}-0.079^{* * *} \\
(0.018)\end{array}$ & $\begin{array}{c}-0.042^{* *} \\
(0.019)\end{array}$ & $\begin{array}{l}0.127^{* * *} \\
(0.035)\end{array}$ & $\begin{array}{l}0.066^{* * *} \\
(0.024)\end{array}$ & $\begin{array}{l}-0.068 \\
(0.045)\end{array}$ & $\begin{array}{c}-0.022 \\
(0.026)\end{array}$ \\
\hline$N$ & 12807 & 12807 & 12748 & 12748 & 11703 & 11703 & 11703 & 11703 \\
\hline$R^{2}$ & 0.098 & 0.122 & 0.084 & 0.108 & 0.136 & 0.219 & 0.058 & 0.097 \\
\hline $\begin{array}{l}\text { Log \% cousin m. } \\
\text { (mother's o. country) }\end{array}$ & $\begin{array}{c}-0.073^{* * *} \\
(0.013)\end{array}$ & $\begin{array}{l}-0.050^{* * *} \\
(0.012)\end{array}$ & $\begin{array}{c}-0.078^{* * *} \\
(0.013)\end{array}$ & $\begin{array}{l}-0.051^{* * *} \\
(0.016)\end{array}$ & $\begin{array}{l}0.092^{* * *} \\
(0.020)\end{array}$ & $\begin{array}{l}0.051^{* * *} \\
(0.014)\end{array}$ & $\begin{array}{c}-0.063^{* * *} \\
(0.017)\end{array}$ & $\begin{array}{l}-0.032^{* *} \\
(0.015)\end{array}$ \\
\hline$N$ & 7508 & 7508 & 7484 & 7484 & 6875 & 6875 & 6875 & 6875 \\
\hline$R^{2}$ & 0.101 & 0.127 & 0.089 & 0.115 & 0.131 & 0.234 & 0.059 & 0.100 \\
\hline $\begin{array}{l}\text { W. Church exp. (mother's. o. country) } \\
\text { (in } 100 \text { yrs.) }\end{array}$ & $\begin{array}{l}0.019^{* *} \\
(0.008)\end{array}$ & $\begin{array}{c}0.009 \\
(0.008)\end{array}$ & $\begin{array}{l}0.015^{*} \\
(0.008)\end{array}$ & $\begin{array}{c}0.002 \\
(0.009)\end{array}$ & $\begin{array}{c}-0.028^{* * *} \\
(0.011)\end{array}$ & $\begin{array}{c}-0.012^{* *} \\
(0.006)\end{array}$ & $\begin{array}{c}0.018 \\
(0.012)\end{array}$ & $\begin{array}{c}0.006 \\
(0.009)\end{array}$ \\
\hline $\begin{array}{l}\text { E. Church exp. (mother's. o. country) } \\
\text { (in } 100 \text { yrs.) }\end{array}$ & $\begin{array}{c}0.028 \\
(0.019)\end{array}$ & $\begin{array}{c}0.016 \\
(0.016)\end{array}$ & $\begin{array}{c}0.006 \\
(0.014)\end{array}$ & $\begin{array}{l}-0.009 \\
(0.013)\end{array}$ & $\begin{array}{c}-0.056^{* * *} \\
(0.014)\end{array}$ & $\begin{array}{c}-0.030^{* * *} \\
(0.008)\end{array}$ & $\begin{array}{c}0.031 \\
(0.025)\end{array}$ & $\begin{array}{l}0.015 \\
(0.020)\end{array}$ \\
\hline$N$ & 12415 & 12415 & 12358 & 12358 & 11347 & 11347 & 11347 & 11347 \\
\hline$R^{2}$ & 0.096 & 0.122 & 0.083 & 0.108 & 0.133 & 0.218 & 0.060 & 0.098 \\
\hline Basic individual controls & Yes & Yes & Yes & Yes & Yes & Yes & Yes & Yes \\
\hline Resident country \& wave FE & Yes & Yes & Yes & Yes & Yes & Yes & Yes & Yes \\
\hline Mother's. o country baseline controls & Yes & Yes & Yes & Yes & Yes & Yes & Yes & Yes \\
\hline Further individual controls & - & Yes & - & Yes & - & Yes & - & Yes \\
\hline Religious denomination \& religiousness & - & Yes & - & Yes & - & Yes & - & Yes \\
\hline \multicolumn{9}{|c|}{$\begin{array}{l}\text { Table S6.4: OLS regression of the ESS-based psychological variables on KII, log percent-cousin marriage, and Western and Eastern Church } \\
\text { exposure (in } 100 \text { years) of the origin country of the respondent's mother. Each observation is the child of an immigrant mother. All regressions } \\
\text { control for basic individual controls (age, age-squared, gender); wave and country of residence fixed effects; and the baseline set of mother's origin } \\
\text { country-level controls (absolute latitude, ruggedness, caloric suitability for agriculture, mean distance to waterways, and percent tropical climate). In } \\
\text { addition, all even numbered columns include further individual indicator variables (marriage status, feeling discriminated against, secondary } \\
\text { education, tertiary education, unemployed and searching for a job, and inactivity in the labor market), religious denominations and religiousness. } \\
\text { Robust standard errors two-way clustered at the resident and mother's origin country are reported in parentheses. * } P \leq 0.1,{ }^{* *} P \leq 0.05,{ }^{* * *} P \leq 0.01 \\
\text { (two-sided). }\end{array}$} \\
\hline
\end{tabular}

\section{iii. Robustness check: Resident country's region fixed effects}

The specifications in the previous analysis (Table 6.1) included resident country fixed effects. In Section S4, we have shown that regions within European countries differ along the dimensions of Church exposure and kinship intensity. There may thus be differences in the regions' attractiveness for immigrants, and these differences could depend on the level of kinship intensity in the regions. In addition, socialization may also vary across regions, possibly in ways that are related to the regions' levels of kinship intensity. To address this concern, we included fixed effects for residence region instead of country in the regression. Since the ESS does not contain information on the residence region in all waves and all countries, the sample is based on the subset of wave/country combinations for which we have information on the residence region. In addition, all regressions control for dummy variables on the self-reported city size (big city, suburb or outskirt of big city, town or small city, country village, farm or home in countryside). This mitigates the concern that our estimates may be biased by immigrants differentially selecting into cities based on kinship intensity. Table 
S6.5 reveals similar estimates in this alternative specification and suggests that endogenous migration to cities or regions within countries is unlikely to bias our estimates.

\begin{tabular}{|c|c|c|c|c|c|c|c|c|}
\hline & \multicolumn{2}{|c|}{ Gen. trust } & \multicolumn{2}{|c|}{ Gen. fairness } & \multicolumn{2}{|c|}{$\begin{array}{l}\text { Conformity- } \\
\text { obedience }\end{array}$} & \multicolumn{2}{|c|}{$\begin{array}{l}\text { Individualism- } \\
\text { independence }\end{array}$} \\
\hline & (1) & (2) & (3) & (4) & (5) & (6) & (7) & (8) \\
\hline $\begin{array}{l}\text { KII } \\
\text { (mother's o. country) }\end{array}$ & $\begin{array}{l}-0.102^{* * *} \\
(0.019)\end{array}$ & $\begin{array}{c}-0.068^{* * *} \\
(0.019)\end{array}$ & $\begin{array}{c}-0.076^{* * *} \\
(0.018)\end{array}$ & $\begin{array}{l}-0.031 \\
(0.020)\end{array}$ & $\begin{array}{l}0.133^{* * *} \\
(0.035)\end{array}$ & $\begin{array}{l}0.067^{* * *} \\
(0.024)\end{array}$ & $\begin{array}{l}-0.066^{* *} \\
(0.030)\end{array}$ & $\begin{array}{l}-0.016 \\
(0.022)\end{array}$ \\
\hline$N$ & 8579 & 8579 & 8537 & 8537 & 7950 & 7950 & 7950 & 7950 \\
\hline$R^{2}$ & 0.103 & 0.125 & 0.089 & 0.111 & 0.165 & 0.235 & 0.061 & 0.096 \\
\hline $\begin{array}{l}\text { Log \% cousin marriage } \\
\text { (mother's o. country) }\end{array}$ & $\begin{array}{c}-0.059^{* * *} \\
(0.016)\end{array}$ & $\begin{array}{l}-0.029 \\
(0.019)\end{array}$ & $\begin{array}{c}-0.074^{* * *} \\
(0.014)\end{array}$ & $\begin{array}{l}-0.045^{* *} \\
(0.017)\end{array}$ & $\begin{array}{l}0.106^{* * *} \\
(0.019)\end{array}$ & $\begin{array}{c}0.054^{* * *} \\
(0.015)\end{array}$ & $\begin{array}{l}-0.073^{* * *} \\
(0.019)\end{array}$ & $\begin{array}{l}-0.030^{*} \\
(0.017)\end{array}$ \\
\hline$N$ & 4433 & 4433 & 4422 & 4422 & 4123 & 4123 & 4123 & 4123 \\
\hline$R^{2}$ & 0.116 & 0.140 & 0.103 & 0.126 & 0.162 & 0.258 & 0.063 & 0.102 \\
\hline $\begin{array}{l}\text { W. Church exp. (mother's. o. country) } \\
\text { (in } 100 \text { yrs.) }\end{array}$ & $\begin{array}{l}0.023^{* * *} \\
(0.007)\end{array}$ & $\begin{array}{c}0.011 \\
(0.007)\end{array}$ & $\begin{array}{l}0.014^{*} \\
(0.007)\end{array}$ & $\begin{array}{l}-0.001 \\
(0.008)\end{array}$ & $\begin{array}{c}-0.037^{* * *} \\
(0.010)\end{array}$ & $\begin{array}{l}-0.015^{* *} \\
(0.007)\end{array}$ & $\begin{array}{l}0.024^{* *} \\
(0.011)\end{array}$ & $\begin{array}{c}0.008 \\
(0.008)\end{array}$ \\
\hline $\begin{array}{l}\text { E. Church exp. (mother's. o. country) } \\
\text { (in } 100 \text { yrs.) }\end{array}$ & $\begin{array}{l}0.038^{* *} \\
(0.016)\end{array}$ & $\begin{array}{c}0.025 \\
(0.017)\end{array}$ & $\begin{array}{c}0.012 \\
(0.015)\end{array}$ & $\begin{array}{l}-0.005 \\
(0.015)\end{array}$ & $\begin{array}{c}-0.056^{* * *} \\
(0.015)\end{array}$ & $\begin{array}{c}-0.029^{* *} \\
(0.011)\end{array}$ & $\begin{array}{c}0.024^{*} \\
(0.014)\end{array}$ & $\begin{array}{c}0.008 \\
(0.012)\end{array}$ \\
\hline$N$ & 8292 & 8292 & 8250 & 8250 & 7686 & 7686 & 7686 & 7686 \\
\hline$R^{2}$ & 0.101 & 0.124 & 0.088 & 0.111 & 0.163 & 0.235 & 0.063 & 0.097 \\
\hline Basic individual controls, & Yes & Yes & Yes & Yes & Yes & Yes & Yes & Yes \\
\hline Resident-region FE, Wave FE & Yes & Yes & Yes & Yes & Yes & Yes & Yes & Yes \\
\hline City-size & Yes & Yes & Yes & Yes & Yes & Yes & Yes & Yes \\
\hline Mother's o. country baseline controls & Yes & Yes & Yes & Yes & Yes & Yes & Yes & Yes \\
\hline Further individual controls & - & Yes & - & Yes & - & Yes & - & Yes \\
\hline Religious denomination \& religiousness & - & Yes & - & Yes & - & Yes & - & Yes \\
\hline \multicolumn{9}{|c|}{$\begin{array}{l}\text { Table S6.5: OLS regression of the ESS-based psychological variables on KII, log percent-cousin marriage, and Western and Eastern Church } \\
\text { exposure (in } 100 \text { years) of the origin country of the respondent's mother. Each observation is the child of an immigrant mother. All regressions } \\
\text { control for basic individual controls (age, age-squared, gender); wave of survey and region of residence fixed effects; dummy variables for self- } \\
\text { reported city size (big city, suburb or outskirt of big city, town or small city, country village, farm or home in countryside); and the baseline set of } \\
\text { mother's origin country controls (absolute latitude, ruggedness, caloric suitability for agriculture, and mean distance to waterways). In addition, all } \\
\text { even numbered columns include further individual indicator variables (marriage status, feeling discriminated against, secondary education, tertiary } \\
\text { education, unemployed and searching for a job, and inactivity in the labor market), religious denominations and religiousness. Robust standard } \\
\text { errors clustered at the resident country-level are reported in parentheses. }{ }^{*} P \leq 0.1,{ }^{* *} P \leq 0.05, * * * P \leq 0.01 \text { (two-sided). }\end{array}$} \\
\hline
\end{tabular}

\section{iv. Robustness Check: KII without polygyny}

We discussed that polygyny- which leaves a large proportion of men unmarried and without an affinal kin network - is arguably more ambiguous compared to the other sub-indicators with regard to how it should be related to kinship intensity. Here we demonstrate that the results hold when we regress the psychological variables on the KII without the polygamy sub-indicator and instead control for polygamy separately. The coefficients for the KII without polygamy decrease slightly compared to Table S6.1, but overall paint a very similar picture to the KII that includes all sub-indicators. The coefficients for polygamy have the same signs as the ones for the KII without polygamy but are not significant.

\begin{tabular}{|c|c|c|c|c|c|c|c|c|}
\hline & \multicolumn{2}{|c|}{ Gen. trust } & \multicolumn{2}{|c|}{ Gen. fairness } & \multicolumn{2}{|c|}{$\begin{array}{c}\text { Conformity- } \\
\text { obedience }\end{array}$} & \multicolumn{2}{|c|}{$\begin{array}{l}\text { Individualism- } \\
\text { independence }\end{array}$} \\
\hline & (1) & (2) & (3) & (4) & (5) & (6) & (7) & $(8)$ \\
\hline $\begin{array}{l}\text { KII without polygamy } \\
\text { (mother's o. country) }\end{array}$ & $\begin{array}{l}-0.082^{* * *} \\
(0.012)\end{array}$ & $\begin{array}{l}-0.061^{* * *} \\
(0.013)\end{array}$ & $\begin{array}{l}-0.065^{* * *} \\
(0.019)\end{array}$ & $\begin{array}{l}-0.038^{*} \\
(0.022)\end{array}$ & $\begin{array}{l}0.116^{* * *} \\
(0.026)\end{array}$ & $\begin{array}{l}0.061^{* * *} \\
(0.020)\end{array}$ & $\begin{array}{l}-0.043^{*} \\
(0.022)\end{array}$ & $\begin{array}{l}-0.005 \\
(0.017)\end{array}$ \\
\hline Polygamy & $\begin{array}{l}-0.018 \\
(0.022) \\
\end{array}$ & $\begin{array}{l}-0.003 \\
(0.017) \\
\end{array}$ & $\begin{array}{l}-0.016 \\
(0.035) \\
\end{array}$ & $\begin{array}{l}-0.001 \\
(0.032) \\
\end{array}$ & $\begin{array}{c}0.002 \\
(0.048) \\
\end{array}$ & $\begin{array}{l}-0.001 \\
(0.034) \\
\end{array}$ & $\begin{array}{l}-0.044 \\
(0.036) \\
\end{array}$ & $\begin{array}{l}-0.036 \\
(0.025) \\
\end{array}$ \\
\hline $\begin{array}{l}N \\
R^{2}\end{array}$ & $\begin{array}{l}12807 \\
0.098 \\
\end{array}$ & $\begin{array}{l}12807 \\
0.122 \\
\end{array}$ & $\begin{array}{l}12748 \\
0.084\end{array}$ & $\begin{array}{l}12748 \\
0.108\end{array}$ & $\begin{array}{l}11703 \\
0.136 \\
\end{array}$ & $\begin{array}{l}11703 \\
0.219 \\
\end{array}$ & $\begin{array}{l}11703 \\
0.059\end{array}$ & $\begin{array}{l}11703 \\
0.097 \\
\end{array}$ \\
\hline Basic individual controls, & Yes & Yes & Yes & Yes & Yes & Yes & Yes & Yes \\
\hline Resident-country FE, Wave FE & Yes & Yes & Yes & Yes & Yes & Yes & Yes & Yes \\
\hline Mother's o. country baseline controls & Yes & Yes & Yes & Yes & Yes & Yes & Yes & Yes \\
\hline Further individual controls & - & Yes & - & Yes & - & Yes & - & Yes \\
\hline
\end{tabular}




\begin{abstract}
\begin{tabular}{llllllll} 
Religious denomination \& religiousness & - & Yes & - & Yes & - & Yes \\
\hline
\end{tabular} Table S6.6: OLS regression of the ESS-based psychological variables on mother's origin country's KII without polygamy and polygamy. Each observation is the child of an immigrant mother. All regressions control for basic individual controls (age, age-squared, gender); wave of survey and country of residence fixed effects; and the baseline set of mother's origin country-level controls (absolute latitude, ruggedness, caloric suitability for agriculture, and mean distance to waterways). In addition, all even numbered columns include further individual indicator variables (marriage status, feeling discriminated against, secondary education, tertiary education, unemployed and searching for a job, and inactivity in the labor market), religious denominations and religiousness. Robust standard errors clustered at the resident countrylevel are reported in parentheses. ${ }^{*} P \leq 0.1, * * P \leq 0.05, * * * \mathrm{P} \leq 0.01$ (two-sided).
\end{abstract}

\title{
S6.2 Kinship intensity of ancestral ethnicity and psychological outcomes
}

The ESS contains information on the first and second languages spoken at home. Based on the language spoken at home, we match children of immigrants to ethnicities in the Ethnographic Atlas (EA). Compared to matching at the level of the immigrant parents' origin country (as was done for the analyses reported in Section S6.1 above), this has the advantage of allowing us to control for other pre-industrial, ethnicity-level characteristics and origin country fixed effects.

For the matching, we first coded whether or not children of immigrants speak a first or second language at home that is not one of the prevailing native languages in the resident country. We then prepared the EA for matching based on languages (the procedure is akin to that described in Section S.8 step $1^{59}$ ). In cases where ESS data indicated that both the first and second languages spoken at home were non-native to the residence country, we used the first language for the matching.

In the analyses that follow, we restrict the sample to individuals born in the residence country whose mothers immigrated. In addition, we exclude individuals whose mother and father immigrate from different countries. In this case, individuals may speak their fathers' ancestral ethnicity's language. Thirty-eight percent of children of immigrants in our sample speak a first or second language at home that is not one of the prevailing native languages in the resident country. Out of those, we could match $99 \%$ to an ethnicity in the EA. This sample is considerably smaller than the previous one in Section S6.1, because children of immigrants who only speak the language of their resident country are not included. Consequently, it is a more selected sample. However, in the previous analysis we showed that the results hold in the full sample of all children of immigrants.

Here we take advantage of the ethnicity-level matching, which allows us to control for ethnicity-level characteristics and fixed effects for the immigrant mothers' origin country. Ancestral ethnicity-level characteristics like institutions, or means of subsistence, may have impacted both an ethnicities' intensive kinship and their culturally transmitted psychological characteristics found in the children of immigrants. For example, Buggle (162) demonstrates a robust association between a history of irrigation and individualism. Similarly, societal-level institutions or settlement complexity (which previous research has used as a proxy for prosperity) may impact kinship intensity and psychology. We address this issue by controlling for reliance on fishing, animal husbandry, and agriculture as means of subsistence, use of irrigation, settlement complexity and the (presence and) level of judicial hierarchy at the ethnicity level. In addition, we control for

\footnotetext{
${ }^{59}$ The EA data provided by D-PLACE links each ethnicity to a dialect or language based on Glottolog (Hammarström (233)). In some cases, D-PLACE data on ethnicities' dialects is more detailed than the ESS language classifications. In these cases, we moved up the language tree (based on Glottolog) to arrive at the language level. In cases where several ethnicities spoke dialects of the same language, we took the average over the ethnicities speaking the same language.
} 
fixed effects for the mother's originating country, to address omitted variables bias at the origin country level. This eliminates all between-origin -country variation, leaving only ethnicity-level variation within originating countries, and thus considerably decreases the chances of finding significant effects. By doing this, we go beyond what is standard in studies employing the epidemiological approach (see Galor et al. (231) who implemented a similar estimation strategy).

Table S6.7 reports the regression estimates. We control for baseline demographic characteristics (age, agesquared, and gender), as well as wave and residence country fixed effects in all specifications. In Columns 15 , we also control for the baseline set of origin country geographic variables (absolute latitude, ruggedness, caloric suitability for agriculture, and mean distance to waterways). Columns 6-10 include originating country fixed effects instead of the origin country geographic variables, and they otherwise mirror Columns 1-5. Columns 2-5 and 7-10 include the ethnicity-level controls (reliance on fishing, animal husbandry, and agriculture as means of subsistence, use of irrigation, settlement complexity, and the presence and level of judicial hierarchy at the ethnicity level). Columns 3 and 8 include further individual indicator variables (being married, feeling discriminated against, having secondary education, having tertiary education, being unemployed and searching for a job, and being inactive in the labor market). Columns 4 and 9 add indicator variables for individual's religious denomination and religiousness. Columns 5 and 10 contain all individuallevel factors including religious denomination and religiousness simultaneously.

As expected, we find a negative association between the KII and generalized trust, generalized fairness, and individualism-independence, as well as a positive association between the KII and conformity-obedience. For example, in the case of generalized trust, we see that a one standard deviation in the KII decreases trust by about 0.1 standard deviations (Panel 1, in Column 1), and that the coefficients do not change much when we include additional controls in Columns 2-10. The coefficients remain significant when we include either ethnicity-specific controls (Column 2) or individual-level controls (Column 3). In Columns 4-5, when we add controls for religious denomination and religiousness, the significance level decreases, but the size of the coefficients does not change much. The originating country fixed effects in Columns 6-10 restrict the source of variation to only ethnicities within a country. We still find a significant effect of kinship intensity on generalized trust in Column 6, but as we include additional covariates in Columns 7-10, the coefficients for generalized trust become insignificant. However, the coefficients remain largely unchanged, and the decreased statistical significance is likely due to "bad controls" (175) (since many of these covariates may be the outcome of kinship intensity) or increased imprecision from the inclusion of additional covariates (the standard errors noticeably increase in Columns 7-10).

The other dependent variables paint a similar and consistent picture: generalized fairness and individualismindependence decrease, while conformity-obedience increases with the KII. Even as we include additional control variables, the coefficients maintain the expected sign, and the magnitudes remain relatively stable (although they sometimes exhibit weaker or no statistical significance). The KII is most strongly predictive of conformity. Even when controlling for origin country fixed effects, education or religious denomination, the coefficients are at least weakly significant.

Given that the estimates are based on a selected sample, the estimates may be biased upward. That is, individuals who do not adopt the language of their resident country most likely also have a higher propensity 
to follow norms and customs of their mother's origin country. Nevertheless, it demonstrates that (for the selected sample) the relationship between kinship intensity and psychology holds even when controlling for origin country fixed effects or other ethnicity-level factors. Comparing the estimates to those reported in Table S3.1 demonstrates that the magnitudes of the point estimates are broadly consistent.

\begin{tabular}{|c|c|c|c|c|c|c|c|c|c|c|}
\hline & $(1)$ & (2) & (3) & (4) & $(5)$ & (6) & (7) & $(8)$ & (9) & (10) \\
\hline & \multicolumn{10}{|c|}{ Panel 1: Generalized trust (z-scores) } \\
\hline $\begin{array}{l}\text { KII } \\
\text { (mother's o. ethnicity) }\end{array}$ & $\begin{array}{l}-0.086^{* * *} \\
(0.026)\end{array}$ & $\begin{array}{l}-0.068^{* *} \\
(0.026)\end{array}$ & $\begin{array}{l}-0.056^{* *} \\
(0.026)\end{array}$ & $\begin{array}{l}-0.045 \\
(0.030)\end{array}$ & $\begin{array}{l}-0.044 \\
(0.029)\end{array}$ & $\begin{array}{l}-0.068^{* *} \\
(0.027)\end{array}$ & $\begin{array}{l}-0.055 \\
(0.044)\end{array}$ & $\begin{array}{l}-0.046 \\
(0.044)\end{array}$ & $\begin{array}{l}-0.061 \\
(0.041)\end{array}$ & $\begin{array}{l}-0.055 \\
(0.041)\end{array}$ \\
\hline & 2717 & 2717 & 2717 & 2717 & 2717 & 2785 & 2785 & 2785 & 2785 & 2785 \\
\hline \multirow[t]{2}{*}{$R^{2}$} & 0.068 & 0.072 & 0.092 & 0.077 & 0.096 & 0.103 & 0.105 & 0.123 & 0.108 & 0.126 \\
\hline & \multicolumn{10}{|c|}{ Panel 2: Generalized fairness (z-scores) } \\
\hline & $-0.077^{* * *}$ & $-0.097^{* * *}$ & $-0.089^{* * *}$ & $-0.072^{*}$ & $-0.073^{* *}$ & -0.033 & $-0.108^{*}$ & $-0.104^{*}$ & $-0.104^{*}$ & $-0.103^{*}$ \\
\hline (mother's o. ethnicity) & $(0.024)$ & $(0.031)$ & $(0.031)$ & $(0.036)$ & $(0.035)$ & $(0.028)$ & $(0.055)$ & $(0.054)$ & $(0.059)$ & $(0.057)$ \\
\hline$N$ & 2700 & 2700 & 2700 & 2700 & 2700 & 2767 & 2767 & 2767 & 2767 & 2767 \\
\hline$R^{2}$ & 0.070 & 0.073 & 0.086 & 0.078 & 0.091 & 0.104 & 0.107 & 0.120 & 0.111 & 0.124 \\
\hline \multirow{5}{*}{$\begin{array}{l}\text { KII } \\
\text { (mother's o. ethnicity) } \\
N \\
R^{2} \\
\end{array}$} & \multicolumn{10}{|c|}{ Panel 3: Conformity-obedience (z-scores) } \\
\hline & $0.142^{* * *}$ & $0.178^{* * *}$ & $0.165^{* * *}$ & $0.097^{*}$ & $0.091^{*}$ & $0.183^{* * *}$ & $0.175^{* * *}$ & $0.163^{* * *}$ & $0.106^{* *}$ & $0.095^{*}$ \\
\hline & $(0.033)$ & $(0.048)$ & $(0.046)$ & $(0.050)$ & $(0.047)$ & $(0.039)$ & $(0.050)$ & $(0.050)$ & $(0.049)$ & $(0.048)$ \\
\hline & 2503 & 2503 & 2503 & 2503 & 2503 & 2569 & 2569 & 2569 & 2569 & 2569 \\
\hline & 0.160 & 0.164 & 0.183 & 0.211 & 0.227 & 0.201 & 0.202 & 0.218 & 0.244 & 0.259 \\
\hline & \multicolumn{10}{|c|}{ Panel 4: Individualism-independence (z-scores) } \\
\hline KII & $-0.090^{* *}$ & $-0.115^{* * *}$ & $-0.101^{* * *}$ & $-0.081^{* *}$ & $-0.074^{* *}$ & $-0.116^{* *}$ & $-0.111^{*}$ & $-0.099^{*}$ & -0.082 & -0.071 \\
\hline (mother's o. ethnicity) & $(0.043)$ & $(0.034)$ & $(0.034)$ & $(0.035)$ & $(0.035)$ & $(0.055)$ & $(0.056)$ & $(0.057)$ & $(0.055)$ & $(0.057)$ \\
\hline$N$ & 2503 & 2503 & 2503 & 2503 & 2503 & 2569 & 2569 & 2569 & 2569 & 2569 \\
\hline$R^{2}$ & 0.054 & 0.062 & 0.077 & 0.073 & 0.087 & 0.100 & 0.103 & 0.117 & 0.112 & 0.125 \\
\hline \multirow{7}{*}{$\begin{array}{l}\text { Basic individual controls } \\
\text { Resident country \& wave FE } \\
\text { Mother's o. country } \\
\text { baseline controls } \\
\text { Mother's o. country FE } \\
\text { Mother's o. ethnicity controls } \\
\text { Further individual controls } \\
\text { Religious denom. } \\
\text { \& religiousness }\end{array}$} & Yes & Yes & Yes & Yes & Yes & Yes & Yes & Yes & Yes & Yes \\
\hline & Yes & Yes & Yes & Yes & Yes & Yes & Yes & Yes & Yes & Yes \\
\hline & Yes & Yes & Yes & Yes & Yes & - & - & - & - & - \\
\hline & - & - & - & - & - & Yes & Yes & Yes & Yes & Yes \\
\hline & - & Yes & Yes & Yes & Yes & - & Yes & Yes & Yes & Yes \\
\hline & - & - & Yes & - & Yes & - & - & Yes & - & Yes \\
\hline & - & - & - & Yes & Yes & - & - & - & Yes & Yes \\
\hline
\end{tabular}

Table S6.7 OLS regression of the ESS-based psychological variables on KII of the ancestral ethnicity of the mother according to language spoken at home. Each observation is the child of an immigrant mother. All regressions control for basic individual controls (age, age-squared, gender), as well as wave of survey and region of residence fixed effects. Columns 1-5 include controls for baseline controls in the mother's origin country (absolute latitude, ruggedness, caloric suitability for agriculture, and mean distance to waterways), while Columns 6-10 instead include mother's origin country fixed effects. In Columns 2-5 and 7-10, we include ethnicity-specific controls (reliance on fishing, animal husbandry, and agriculture as means of subsistence, use of irrigation, settlement complexity and the presence and level of judicial hierarchy at the ethnicity level). Columns $3,5,8$, and 10 include further individual indicator variables (marriage status, feeling discriminated against, secondary education, tertiary education, unemployed and searching for a job, and inactivity in the labor market). Columns 4, 5, 9, and 10 include controls for religious denomination and religiousness. Robust standard errors clustered at the resident country level are reported in parentheses. * $P \leq 0.1, * * P \leq 0.05, * * * \mathrm{P} \leq 0.01$ (two-sided). 


\section{S7. Ethnicities' ancestral kinship intensity and psychology}

In this section we add further evidence for the association between kinship intensity and psychological variables by turning to individual data based on the World Value Survey (WVS). We focus on the same WVS-based dependent variable that we used in the cross-country analysis. This section complements the cross-country analysis by focusing on the within-country variation in kinship intensity among individuals of different ethnic backgrounds. Like the analyses based on the ESS, which exploited regional variation in consanguinity in three European countries (Section S4), and the children of immigrants analysis (Section S6), the analysis in this section controls for country fixed effects and therefore relies on within-country variation. It compliments Section S4, since it is not restricted to Europe and therefore contains a larger and more diverse sample of countries. Unlike the analysis of the children of immigrants in Section S6, the analysis here is based on people who are native to a region. Based on individual responses, we can again control for religious denomination (among other individual-level covariates). Thus, again we demonstrate that religious denomination per se does not explain our finding that kinship intensity is associated with the psychological variables. In addition, below we shed light on what the generalized trust question measures and show that it is perceived differently depending on kinship intensity.

The WVS contains information on a respondent's ethnicity. Based on this information, we matched individuals to ethnicities (and hence to kinship intensity) in the Ethnographic Atlas (EA). This was done in two steps. First, we matched the EA ethnicities to the Ethnologue based on the language codes provided by in D-PLACE. Matching to the Ethnologue allows us to code whether an individual's ethnicity is native to the country. We excluded individuals who reported a non-native ethnicity. This analysis therefore does not rest on immigrants or children of immigrants. ${ }^{60}$ Second, we matched the WVS ethnicities manually to the Ethnologue. One drawback, however, is that the WVS only contains data on ethnicities for a subset of observations, and sometimes the ethnic information is coarse. We used only those observations that could be matched to the EA in a straightforward manner. ${ }^{61}$

Table 7.1 reports the regression results. The outcome variables parallel the WVS-based cross-country analysis (see Section S3 for information on these variables). The variables related to the domain of conformity \& obedience are obedience (binary outcome, Columns 1 and 2), tradition (standardized, Columns 3 and 4), and proper behavior (standardized, Columns 5 and 6); the variable related to individualism \& independence is creativity (standardized, Columns 7 and 8). Measures in the domain of impersonal prosociality are out-ingroup trust (normalized between 0 and 1, Columns 9 and 10), generalized trust (binary outcome, Columns 11 and 12), and generalized fairness (normalized between 0 and 1, Columns 13 and 14). To rule out the possibility that country-level omitted variables bias the estimates, we include country fixed effects. In addition, all regressions control for survey wave fixed effects and basic individual controls (gender, age, and age squared). All even numbered columns control for further individual-level covariates: the importance individuals place on religion (varies between 0 for "not at all important" and 3 for "very

\footnotetext{
${ }^{60}$ The results hardly change when we include non-native individuals in the sample (available upon request).

${ }^{61}$ For example, in some countries the religion instead of the ethnicity was reported, while in other cases, broad categories like "white" were used. In these cases, we did not match the ethnicities to the WVS.
} 
important"), dummy variables for religious denomination, ${ }^{62}$ and educational attainment (no formal or inadequate primary education, primary or incomplete secondary education, secondary or incomplete tertiary education, tertiary education).

The results reveal that, within a country, people who belong to an ethnicity with a higher ancestral KII tend to score higher on obedience ( $P=0.12$, in Column 1$)$ and significantly higher on tradition, while, consistent with the cross-country analysis, there is no statistical association with proper behavior. A higher KII is negatively associated with creativity. A highly significant association exists between KII and out-ingroup trust, while a relationship also exists with the generalized trust question even though the significance levels are lower. The higher significance of the results for out-ingroup trust is not surprising. Unlike the generalized trust question, the out-ingroup trust measure takes into account who the people to be trusted are. Previously in the crosscountry regression analysis, we did not find a significant association between kinship intensity and generalized trust, and below we analyze this issue in more detail. In addition to the generalized trust question, we also do not find a significant association with the fairness question in Table S7.1. All results are quantitatively and qualitatively similar when controlling for educational attainment, religiousness, and religious denominations. This is further evidence that religious practices do not drive our results.

Our KII at the ethnicity level relies on predicted values of cousin-marriage preference based on cousin terms (see Section S1). We found that the results are sensitive to the inclusion of those predicted values. When we construct a KII that is based only on actual, non-predicted values, the significant results in Table S7.1 disappear. One reason for this could be that using the KII that does not rest on predicted values decreases the sample size considerably. In the case of generalized trust (Columns 11 and 12) sample size is reduced by about 6,500 observations or about 14\%; in the case of out-ingroup trust (Columns 9 and 10) sample size is reduced by about 4,600 observations or about $19 \%$. As a robustness check, we created a KII that only rests on the four other sub-indicators (Spearman's $\rho=0.92, P<0.001, N=1054$ ). In this way, we reach a similar number of observations. The results are qualitatively similar to the ones reported in Table S7.1: the KII is highly significantly associated with out-ingroup trust and tradition, and, when not controlling for the covariates reported in the even-numbered columns, is weakly associated with proper behavior and creativity. Generalized trust in this specification has the expected sign but is not significant (results available upon request). Overall this suggests that the results are not an artifact of imputing missing values for the subindicator cousin marriage preferred.

${ }^{62}$ The WVS lists numerous detailed religious denominations with classifications varying by country. We included a dummy variable for each. 


\begin{tabular}{|c|c|c|c|c|c|c|c|c|c|c|c|c|c|c|}
\hline & \multicolumn{6}{|c|}{ Conformity \& obedience } & \multirow{2}{*}{\multicolumn{2}{|c|}{$\begin{array}{c}\begin{array}{c}\text { Individualism \& } \\
\text { independence }\end{array} \\
\text { Creativity }\end{array}$}} & \multicolumn{6}{|c|}{ Impersonal prosociality } \\
\hline & \multicolumn{2}{|c|}{ Obedience } & \multicolumn{2}{|c|}{ Tradition } & \multicolumn{2}{|c|}{$\begin{array}{c}\text { Proper } \\
\text { behavior }\end{array}$} & & & \multicolumn{2}{|c|}{ Out-ingroup trust } & \multicolumn{2}{|c|}{ Gen. trust } & \multicolumn{2}{|c|}{ Gen. fairness } \\
\hline & (1) & (2) & (3) & (4) & (5) & (6) & (7) & $(8)$ & (9) & (10) & (11) & (12) & (13) & (14) \\
\hline KII & $\begin{array}{c}0.04 \\
(0.02)\end{array}$ & $\begin{array}{l}0.04^{*} \\
(0.02)\end{array}$ & $\begin{array}{l}0.11^{* * * *} \\
(0.02)\end{array}$ & $\begin{array}{l}0.08^{* * *} \\
(0.02)\end{array}$ & $\begin{array}{c}0.02 \\
(0.02)\end{array}$ & $\begin{array}{c}0.02 \\
(0.02)\end{array}$ & $\begin{array}{c}-0.06^{* * * *} \\
(0.02)\end{array}$ & $\begin{array}{l}-0.06^{* *} \\
(0.02)\end{array}$ & $\begin{array}{c}-0.01^{* * *} \\
(0.00)\end{array}$ & $\begin{array}{c}-0.02^{* * *} \\
(0.00)\end{array}$ & $\begin{array}{l}-0.02^{* *} \\
(0.01)\end{array}$ & $\begin{array}{l}-0.02^{*} \\
(0.01)\end{array}$ & $\begin{array}{c}0.00 \\
(0.00)\end{array}$ & $\begin{array}{c}0.01 \\
(0.01)\end{array}$ \\
\hline Religious denom. & & Yes & & Yes & & Yes & & Yes & & Yes & & Yes & & Yes \\
\hline Religiousness & & Yes & & Yes & & Yes & & Yes & & Yes & & Yes & & Yes \\
\hline Education & & Yes & & Yes & & Yes & & Yes & & Yes & & Yes & & Yes \\
\hline $\begin{array}{l}\text { Country \& wave FE } \\
\text { Basic indiv. controls }\end{array}$ & Yes & Yes & Yes & Yes & Yes & Yes & Yes & Yes & Yes & Yes & Yes & Yes & Yes & Yes \\
\hline$N$ & 46744 & 46744 & 26561 & 26561 & 26561 & 26561 & 26561 & 26561 & 24442 & 24442 & 44743 & 44743 & 27213 & 27213 \\
\hline$R^{2}$ & 0.151 & 0.157 & 0.115 & 0.157 & 0.064 & 0.071 & 0.052 & 0.069 & 0.114 & 0.118 & 0.090 & 0.093 & 0.081 & 0.084 \\
\hline Clusters & 41 & 41 & 28 & 28 & 28 & 28 & 28 & 28 & 26 & 26 & 41 & 41 & 27 & 27 \\
\hline
\end{tabular}

Table S7.1: OLS regression of the WVS-based psychological variables on the KII. All regressions include country and wave fixed effects as well as basic individual controls (age, age squared and gender). In addition, all even numbered columns control for religious denomination, religiousness and education levels (no formal or inadequate primary education, primary education and incomplete secondary, secondary and incomplete tertiary, tertiary education). Robust standard errors clustered at the country level are reported in parentheses. * $P \leq 0.1, * *$ $P \leq 0.05, * * * \mathrm{P} \leq 0.01$ (two-sided). 


\section{What does the generalized trust question measure?}

At the cross-country level, the association between the generalized trust and fairness questions and kinship intensity are weak. The generalized trust and fairness questions fail to define the relationship between the respondent and target person. Depending on the kinship intensity of the ancestral ethnicity, the questions may be understood quite differently. At the country level, we were therefore not surprised to find no association between the KII and generalized trust but to find it for the out-ingroup trust measure. The component questions of the out-ingroup trust measure specify the relationship between the respondent and the person who they may or may not trust.

Here we shed light on this conjecture. First, we investigate how the trust question might be differently understood depending on kinship intensity. Our hypothesis is that in low kinship intensity societies, respondents think that the trust question refers to people in general. In these societies everyday interactions with strangers are common. However, in high kinship intensity societies, where interactions occur mostly in the family and local network, people variously think that either it refers to this in-group member (whom they trust) or that it refers to strangers (whom they don't trust). We focus on the generalized trust question rather than the fairness question since we can relate it to the out-ingroup trust measure. To test our hypothesis, we therefore regress the generalized trust question on the out-ingroup trust measure (Column 1, Table S7.2) and on kinship intensity as well as kinship intensity interacted with the out-ingroup trust measure (Column 2, Table S7.2). The interaction can shed light on how the generalized trust question is perceived depending on kinship intensity. If there is indeed a differential response to the generalized trust question depending on kinship intensity, we expect to find the following: out-ingroup trust will significantly predict the generalized trust question in lower KII individuals, but this relationship will vanish as KII increases. A positive coefficient for out-ingroup trust and a negative interaction (of a similar magnitude) between KII and outingroup trust would suggest that (a) individuals in low KII societies perceive the generalized trust questions as referring to out-group trust and (b) this relationship is not present in high KII societies. The regression analysis confirms our hypothesis: out-ingroup trust predicts generalized trust both in Columns 1 and 2, and there is a significant interaction between kinship intensity and out-ingroup trust in Column 2. The highly significant negative interaction (of a similar magnitude) demonstrates that generalized trust is interpreted differently in high kinship intensity societies. There, out-ingroup trust is hardly predictive of the response to the generalized trust question.

\section{Within vs. between country analysis and European regional analysis}

In our cross-country analysis, we did not find a robust relationship between kinship intensity and the generalized trust question. However, we did find an association in the within-country analyses of European regions (Section S4 and the children-of-immigrants analysis in Section S6) and the within-country analysis in this Section S7, Table S7.1. Here, we discuss and demonstrate how these results can be reconciled.

Previous studies have demonstrated that the trust and fairness questions indeed relate to experimental measures, which were elicited in controlled experimental settings with financial incentives. This validates these measures at the individual level within those societies in which the experiments were conducted. For example, Thöni and coauthors $(209,210,232)$ demonstrate that individual answers to the trust and fairness 
questions are related to cooperative behavior in the PGG (in samples of Danish, German and Russian university students). Interestingly, the trust question seems to be more closely related to cooperative dispositions or preference, while the fairness question is more closely related to beliefs about others' cooperative behavior (210). At the individual level, these questions are therefore predictive of behavior. However, using countries' average trust and fairness levels (based on the WVS), Thöni (209) finds only a weak association with average PGG behavior in the 16 societies of the Hermann et al. (129) study. Similarly, Gaechter and Schulz (128) demonstrate that the fairness question is predictive of dishonesty at the individual level when pooling data from 23 subject pools from around the world. Yet, this is not the case at the country level, when using the average response to the WVS fairness question. This suggests that there are cultural differences in the way that individuals answer the trust and fairness questions. The questions might be perceived quite differently depending on the cultural context, washing out any relationships in cross-country analyses. However, within a more culturally homogenous group, respondents may interpret the questions similarly, and the questions may thus better predict behavior. These examples demonstrate that - just like in our analysis - the generalized trust and fairness questions may capture impersonal trust and fairness within more homogenous countries but fail to do so in a cross-country context.

In Columns 3 and 4 of Table 7.2 we therefore control for country fixed effects. This reveals that out-ingroup trust is a highly significant predictor of the generalized trust question within countries (Column 3). While the coefficient does not change much between Columns 1 and 3, the standard error decreases considerably. Also, in Column 4 the coefficient for the interaction between KII and out-ingroup trust is only weakly significant and is much smaller than it the coefficient in Column 2. This suggests that the trust question is more informative when analyzing within-country variation.

In Columns 5 to 8 we replicate Column 1 to 4 in a sample that only contains respondents from European countries. In this sample the coefficients on out-ingroup trust are considerably larger. Importantly, while the KII is negative and weakly significant, the interaction between the KII and out-ingroup trust is not. This suggests that within Europe the generalized trust question is understood similarly and relates to impersonal trust.

The analysis so far rested on the selected sample for which we could match the KII to a respondent based on self-reported ethnicity. Columns 9 to 12 report the association between out-ingroup trust in the full sample (Columns 9 and 10) and the European sample (Columns 11 and 12). The generalized trust questions exhibits a considerably more pronounced association with out-ingroup trust in the European sample than in the full sample, with the coefficients in the European sample being nearly twice as large. Overall, this analysis reveals that one needs to be careful when analyzing the generalized trust question in cross-country regressions, and that the generalized trust question does a better job in measuring impersonal trust within Europe. 


\begin{tabular}{|c|c|c|c|c|c|c|c|c|c|c|c|c|}
\hline & \multicolumn{4}{|c|}{ Match-able to KII sample } & \multicolumn{4}{|c|}{$\begin{array}{c}\text { Generalized trust } \\
\text { Match-able to KII European sub-sample }\end{array}$} & \multicolumn{2}{|c|}{ Full sample } & \multicolumn{2}{|c|}{ Europe sample } \\
\hline & (1) & (2) & (3) & (4) & (5) & (6) & (7) & (8) & (9) & $(10)$ & (11) & (12) \\
\hline Out-ingroup trust & $\begin{array}{l}0.030^{* *} \\
(0.014)\end{array}$ & $\begin{array}{l}0.027^{* *} \\
(0.010)\end{array}$ & $\begin{array}{l}0.031^{* * *} \\
(0.006)\end{array}$ & $\begin{array}{l}0.030^{* * *} \\
(0.005)\end{array}$ & $\begin{array}{l}0.043^{* * *} \\
(0.004)\end{array}$ & $\begin{array}{l}0.050^{* * *} \\
(0.009)\end{array}$ & $\begin{array}{l}0.042^{* * *} \\
(0.003)\end{array}$ & $\begin{array}{l}0.035^{* * *} \\
(0.004)\end{array}$ & $\begin{array}{c}0.048^{* * *} \\
(0.009)\end{array}$ & $\begin{array}{l}0.038^{* * *} \\
(0.004)\end{array}$ & $\begin{array}{l}0.092^{* * *} \\
(0.014)\end{array}$ & $\begin{array}{l}0.067^{* * *} \\
(0.008)\end{array}$ \\
\hline KII & & $\begin{array}{l}-0.024 \\
(0.017)\end{array}$ & & $\begin{array}{l}-0.013 \\
(0.008)\end{array}$ & & $\begin{array}{l}-0.035^{*} \\
(0.019)\end{array}$ & & $\begin{array}{l}-0.046^{*} \\
(0.022)\end{array}$ & & & & \\
\hline KII X out-ingroup trust & & $\begin{array}{c}-0.018^{* * *} \\
(0.006)\end{array}$ & & $\begin{array}{l}-0.006^{*} \\
(0.003)\end{array}$ & & $\begin{array}{c}0.001 \\
(0.005)\end{array}$ & & $\begin{array}{l}-0.005 \\
(0.003)\end{array}$ & & & & \\
\hline Country FE & & & Yes & Yes & & & Yes & Yes & & Yes & & Yes \\
\hline$N$ & 24443 & 24443 & 24443 & 24443 & 6678 & 6678 & 6678 & 6678 & 136965 & 136965 & 35816 & 35816 \\
\hline$R^{2}$ & 0.005 & 0.014 & 0.097 & 0.097 & 0.008 & 0.014 & 0.036 & 0.037 & 0.013 & 0.136 & 0.031 & 0.154 \\
\hline
\end{tabular}




\section{PART III: DATA}

In Part III, we first describe our novel method for calculating country indicators based on pre-industrial ethnographic data from the Ethnographic Atlas (section S8). In Section S9, we describe the data used in our analyses. 


\section{S8. Linking the Ethnographic Atlas to current countries of the world}

We developed a novel method for matching pre-industrial ethnographic data from the Ethnographic Atlas (EA) to current ethno-linguistic groups, which allows us to calculate population-weighted country indicators such as the country-level Kinship Intensity Index (KII). Our method is similar to that of Giuliano and Nunn (44). Unlike their manual matching of ethnicities to contemporary ethno-linguistic groups, however, our method uses language trees, which allows computational matching based on an algorithm.

Creating country-level indicators based on the pre-industrial EA ethnicities is done in three steps. In Step 1, we match the EA ethnicities from D-PLACE to Glottolog's language trees (233). In Step 2, we use the information contained in the language trees to impute, on the basis of linguistic proximity, ethnographic information for ethno-linguistic groups with missing information. Imputing ethnographic information using language trees allows us to obtain ethnographic data for a large set of populations that speak languages that are not spoken by EA populations, but that are linguistically proximal to a language spoken by an EA population. In Step 3, we use information on ethno-linguistic groups' geographic locations from the Ethnologue and population density from Gridded Population of the World (GPWv4, (234)) to calculate population-weighted ethnographic indicators such as the KII for each country. The following describes our methodology in detail.

\section{Step 1. Mapping the Ethnographic Atlas' languages to language trees.}

In the first step, we match EA ethnicities to the Glottolog's (233) language trees. We use data from the extended version of the Ethnographic Atlas (31-36) provided by the Database of Places, Language, Culture, and Environment (D-PLACE), which includes data on 1,291 pre-industrial ethnicities. We dropped 8 ethnicities for which the ethnographic information refers to a year before $1500 \mathrm{CE}$. D-PLACE ethnicities contain Glottolog IDs, allowing for a straightforward matching.

Glottolog is a databank that contains information on language trees, which represent genealogical hypotheses of how languages are nested in 242 families, 188 isolates (one-member families), 3,871 sub-families, and 8,209 languages with 10,414 dialects. Consider the European language family, which includes many language sub-families, such as the Franconian language sub-family. The branches of the Franconian language subfamily end with languages (such as German, Luxembourgish, and Dutch) and their dialects. All of these subfamilies, languages, and dialects are linked together through Glottolog IDs. For example, the grandfatherGlottolog ID of Luxembourgish is the same as the father-Glottolog ID of German (see Figure S8.1).

Ultimately, we are interested in information on ancestral ethnic characteristics at the level of languages (not dialects). Language-level information allows us to link ancestral characteristics to current ethno-linguistic groups based on Ethnologue (Step 3). Glottolog allows us to link dialects spoken by EA ethnicities to languages. We use 1,283 EA ethnicities associated with 1,105 unique languages. While most of the 1,105 languages (or dialects thereof) are spoken by only one EA ethnicity, in several cases multiple ethnicities speak different dialects of the same language. In these cases, we calculate the ancestral characteristic of interest $x$ (such as cousin marriage preference) at the language level by taking the average over the ethnicities that 
speak different dialects of the same language. Since the number of current ethno-linguistic groups residing in today's countries considerably exceeds the 1,105 based on the EA, we fill in missing groups in Step 2 .

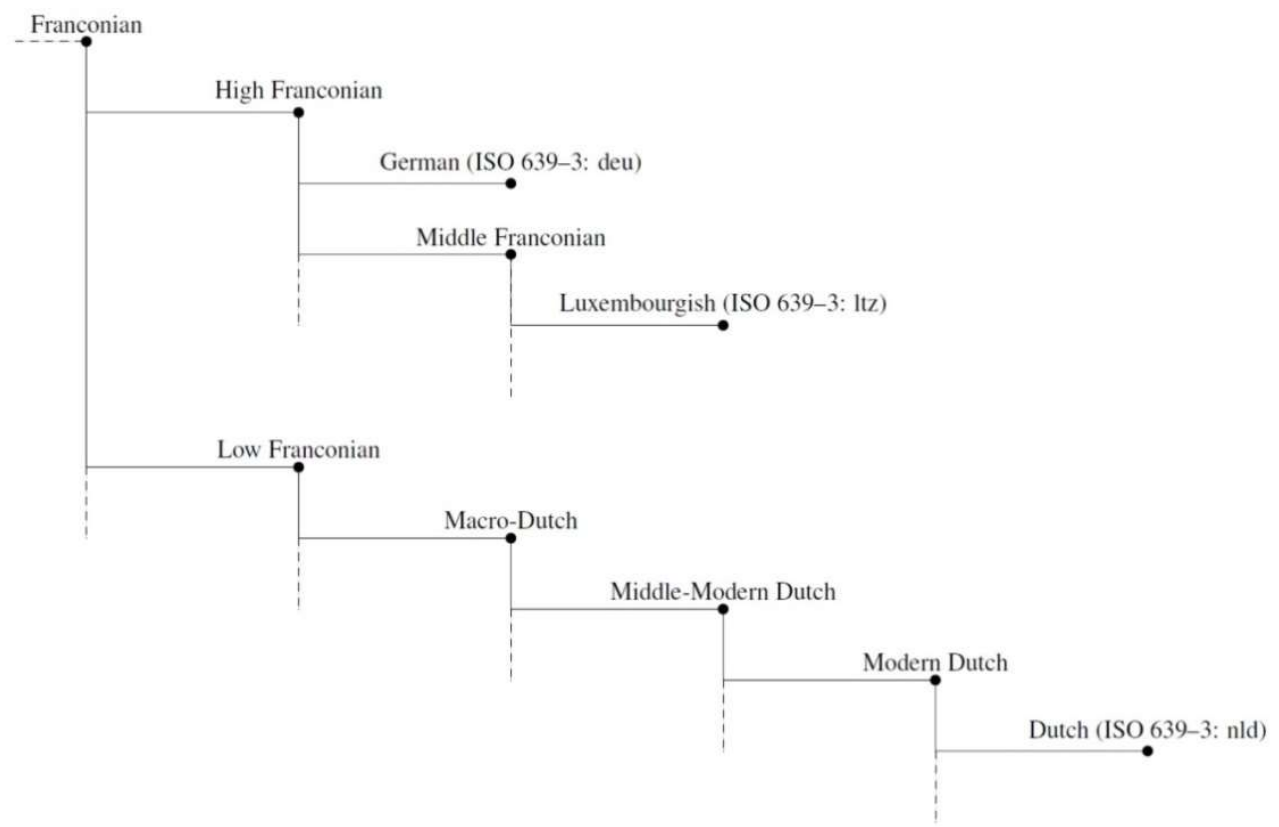

Figure S8.1 Franconian sub-family according to the Glottolog language tree. The nodes in the figure represent sub-families. Only those with ISO 639-3 codes are also languages. Here, the branches of the language-tree end with languages. However, the languages themselves have offspring (i.e., dialects), which we do not show in this figure.

\section{Step 2. Constructing data within language-trees.}

After Step 1, up to 1,105 (out of the 8,209) languages in Glottolog's language tree have been linked to information on an ancestral characteristic $x$. If a given Glottolog language does not contain data on $x$, we fill in the missing observation with an algorithm that uses information on the language with the smallest linguistic distance from the language of interest based on Glottolog's language tree. In cases where there are multiple entries that have the same linguistic distance from the missing entry, the geodesic distance ${ }^{63}$ is used.

For example, Luxembourgish is not among the EA languages, so ethnographic information based on the EA is missing for Luxembourgish. To fill in the information on Luxembourgish, we first look at all languages below the node of its father language, i.e., Middle Franconian (see Figure S8.1). There are several possibilities: (i) if there is a language in the sub-family starting at Middle Franconian which contains data for $x$, Luxembourgish is assigned the value of variable $x$ from that language; (ii) if there is more than one language in the sub-family starting at Middle Franconian which contains data for $x$, Luxembourgish is assigned the value from the language with the closest geodesic distance; (iii) if there is no language in the sub-family starting at Middle Franconian, we move to the node identifying its grandfather, i.e. High Franconian, and repeat the same process.

\footnotetext{
${ }^{63}$ The coordinate often represents the geographical center-point of the area where the speakers live
} 
In this example, German is the only other language in the sub-family starting at High Franconian, and there are no EA ethnicities for $x$ that are linked to the German language. Therefore, both Luxembourgish and German are assigned values for variable $x$ from a language in the next level of the language tree, which is the Franconian sub-family. The Dutch language is the only EA language in the Franconian sub-family that contains data for $x$, so Luxembourgish and German are assigned the value of $x$ from Dutch. If the Dutch ethnicity in the EA were missing data for variable $\mathrm{x}$, we would have searched Glottolog's language tree for the EA language that (i) is closest to German, Luxembourgish, Dutch and other languages in the Franconian sub-family and (ii) contains a value for $x$. In that case, all languages in the Franconian sub-family would be assigned the same value for variable $x$ because they all obtain the value from the same EA language. This search along the language tree might lead us to the top of the language tree. Therefore, all languages in Glottolog will pick values for variable $x$, except languages whose whole family (starting at top of the language tree) does not contain any EA information.

\section{Step 3. Mapping language tree data to geographic boundaries.}

Once we have assigned ancestral characteristic $x$ for all 8,209 Glottolog languages, we match the Glottolog languages to today's 7,651 live and geographically concentrated languages of the world in the Ethnologue (Languages of the World). This is done using ISO 639-3 codes provided by Glottolog. We used the Ethnologue data provided by World Language Mapping System (WLMS) 19th version (2017) which corresponds to the 16th Edition of the Ethnologue ((234)). WLMS also provides a shapefile that divides the world into polygons indicating the locations where 7,651 Ethnologue languages are spoken. ${ }^{64}$ Figure S8.2 shows the borders of the Ethnologue polygons representing ethno-linguistic groups that speak different languages (in red solid lines) for Europe. Each polygon represents the approximate borders of different language groups today.

\footnotetext{
${ }^{64}$ These polygons are made only for geographically concentrated languages, not widespread ones.
} 


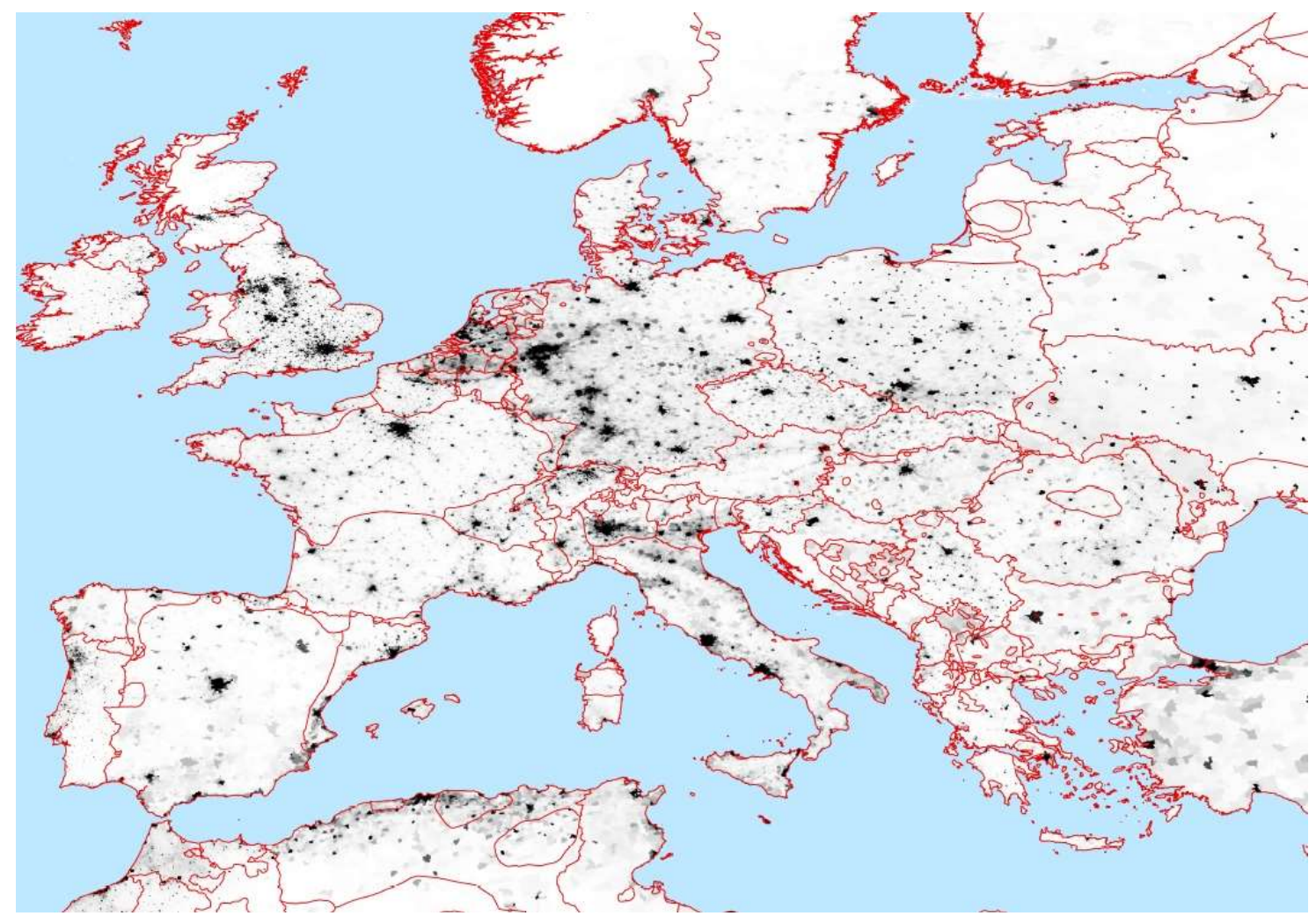

Figure S8.2. Intersection of language polygons (in red solid lines) and population raster data (in shaded regions that are between black and white, with a darker shade indicating higher population density).

To create population weights, we estimate the population of the Ethnologue language groups using the population raster data from Gridded Population of the World (GPWv4, (234)) which consists of estimates of human population density, consistent with national censuses and population registers, for the year 2010 . The GPW uses approximately 12.5 million national and sub-national administrative units to assign population values to 30 arc-second $(\sim 1 \mathrm{~km})$ grid cells. The population count grids contain estimates of the number of people per grid cell. Figure S8.2 also shows the GPW estimate of the population of each cell within the language polygons.

We extract the number of people living within the boundaries of each language polygon. Recall that each language is assigned a value for variable $x$. For each country, our country-level estimate of variable $x$ is the population-weighted average of $x$ across the languages within the boundaries of countries. Using this method, there are a few Ethnologue languages with missing observations for variable $x$. We ignore these missing observations when taking the population-weighted average in a country. 


\section{S9. Data and variables description}

In this section we list the data sources and some additional information on the dependent variables and covariates we used in our analyses. The variables based on the World Value Survey, European Value Survey and the European Social Survey are included here but are described in more detail in other sections of Part II.

\section{S9.1. Dependent variables}

Asch conformity:

Blood donation (country-level): 2011 to 2013. When data for a particular year is missing for a country, the indicator is are covered. In these cases, we did the following: The WHO report states the estimated percentage of blood donations covered; in the non-fully covered countries the coverage is still reasonably high: $60 \%$ of those countries have a coverage above $75 \%$. The total amount of blood donated is calculated based on these estimates provided by the WHO. The WHO report gives further information on the types of donations: (i) voluntary non-remunerated donations, (ii) family/replacement donations, (iii) paid donations, or (iv) other. Our main variable of interest is voluntary non-remunerated donations per 1,000 inhabitants. To calculate per capita values, we divided the number of voluntary non-remunerated donations by the World Bank's population estimates (per 1000) for the year 2012. This variable is used in Section S3.1.

Blood donation (regional-level): Taken from Guiso et al. (229), this variable is the number of 16-ounce blood bags collected per 1000 inhabitants in the year 1995 in Italy. The data is based on AVIS (Italian association of voluntary blood donors), which collects 90 percent of all blood donations and 100 percent of anonymous blood donations in Italy. This variable is used in Section S5.

Conformity-obedience

This variable is based on the answers to four human value questions in the European Social Survey (ESS) that capture conformity and obedience. We pooled the four questions into one measure and calculated the variable at the European-regional level (see Section S4 for a list of the four questions and more details on the construction of the measure).

Creativity

This measure is based on a Schwarz human values question asked in the WVS. People rate on a six-point scale how much they believe the person described in the following sentence is like them: "It is important to this person to think up new ideas and be creative; to do things one's own way." Since we do not want to capture cultural differences in closeness perceptions, we subtracted the mean answers a respondent gave to all human value questions from the respondent's answer to the creativity question following Schwarz's recommendation (193). We aggregated answers to the 
Dishonesty:

Generalized trust

Generalized fairness

Individualism:

Individualism-independence

Nepotism: country level by taking the countries' means and standardized the variable at the country level.

Based on Gaechter and Schulz (128), who conducted a behavioral die-under-the-cup experiment following Fischbacher and Foellmi-Heusi (203), with student participants in 23 countries. In an experimental setting, each participant throws a die in private and reports the number rolled. The payout depends linearly on the number reported: reporting a "1", gives 1 money unit, reporting a " 2 " gives 2 money units, etc.. - except for reporting a " 6 " leads to no payment. In an environment where reputational concerns are minimized, creates an incentive to lie and report high-paying numbers. Our dependent variable, percent high claims, is defined as the percentage of three highpaying numbers reported in each subject pool.

At the cross-country level (Section S3.1), this measure is based on the World Value Survey (WVS) and the European Value Survey (EVS), while at the European regional level, it is based on the European Social Survey (Section S4). In both cases the question is the same: "Generally speaking would you say that most people can be trusted or that you can't be too careful in dealing with people?". In the WVS and EVS (Section S3) the respondents could choose one out of two answers: "Cannot be too careful" or "People can be trusted". In the ESS used in the regional analysis of Section S4, individuals answered on an 11-point scale ranging from "0" ("You can't be too careful") to "10" ("Most people can be trusted").

At the cross-country level, this measure is based on the European Value Survey and World Value Survey (Section S3.1), while at the European regional level, it is based on the European Social Survey (Section S4). The question and answers are identical for all three surveys: "Do you think that most people would try to take advantage of you if they got the chance, or would they try to be fair?".

Our measure for individualism is from Hofstede (retrieved from http:/geerthofstede.com/, accessed 28.10.2015). According to Hofstede: "The high side of this dimension, called individualism, can be defined as a preference for a loosely-knit social framework in which individuals are expected to take care of only themselves and their immediate families. Its opposite, collectivism, represents a preference for a tightly-knit framework in society in which individuals can expect their relatives or members of a particular in-group to look after them in exchange for unquestioning loyalty. A society's position on this dimension is reflected in whether people's selfimage is defined in terms of "I" or "we." The indicator is based on 30 questions. The data was mainly collected among IBM employees around the world.

This variable is based on the answers to two human value questions in the European Social Survey (ESS) that capture individual freedom and independence. We pooled the two questions into one measure and calculated the variable at the European-regional level (see Section S4 for a list of the two questions and details on the construction of the measure).

Taken from Van de Vliert (160). A representative sample of top executives was interviewed by researchers from the World Economic Forum regarding the extent to which senior management positions in their country are held by relatives. They sampled 116 nations (covering 94\% of the world population and 98\% of the gross world product). Within each nation, a partner institute used a master list of organizations grouped by economic sector (agriculture, industry, services), type (domestic private, foreign private, government), and size to draw a nationally 
No-pronoun drop:

Obedience

Out-ingroup trust

Particularism

(passenger's dilemma):

PGG Cooperation representative sample, and then conducted one survey per institution. Data from a total of 10,932 respondents was collected. On average, 94 top executives per country responded to the questionnaire.

We use the data provided by Tabellini (192). He amended the dataset originally coded by Kashima and Kashima (190), resulting in 71 country-level observations. Nopronoun drop equals 1 if the rule forbidding first person pronoun drop is operative and 0 other- wise. Countries with different native languages spoken can take a value in the interval between 0 and 1 .

In the WVS, respondents are asked to choose up to five qualities they consider important to instill in children. Based on responses to this question, we coded the percentage of people in a country who choose "obedience" as an important child quality

This measure is based on World Values Survey (WVS) trust questions which are specific about which group of people can be trusted or not. These questions can be classified into Outgroup and Ingroup trust. The questions are posed in the following way: "I'd like to ask you how much you trust people from various groups. Could you tell me for each whether you trust people from this group completely, somewhat, not very much or not at all?" The various groups are (i) the respondent's family, (ii) the respondent's neighbors, (iii) people the respondent knows personally, (iv) people s/he meets for the first time, (v) people of another religion, and (vi) people of another nationality. While the three former questions all relate to people the respondent is relatively familiar with, the latter three questions refer to more unfamiliar people. Our out-ingroup trust measure is constructed by taking the difference between the average of the last three questions (which plausibly capture out-group trust) and the average of the first three questions (which plausibly capture in-group trust). We took country means and standardized the variable.

Taken from Hampden-Turner and Trompenaars (205). This measure captures the preference for helping kith and kin over following universally applicable rules of fairness. The authors describe the responses of multinational corporate managers to a scenario in which one must make a choice between either helping a friend or telling the truth under oath and compromising the friend. The scenario is the following: "Consider for a moment this dilemma: You are a passenger in a car driven by a close friend, and your close friend's car hits a pedestrian. You know that your friend was going at least thirty-five miles an hour in an area where the maximum speed was twenty miles an hour. There are no witnesses. Your friend's lawyer says that if you testify under oath that the speed was only twenty miles an hour then you would save your friend from any serious consequences. What would you do? Would you lie to protect your friend? What right does your friend have to expect your help? On the other hand, what are your obligations to society to uphold the law?" The variable reveals the percentage of a country's respondents who stated that either (i) the friend has a definite right to expect the respondent to lie for him or (ii) the respondent would lie under oath. Data was updated in successive publications, so we took the most recent data available for each country. 
(with \& without punishment):

Proper behavior

Tightness:

Tradition

UN diplomatic
We use two experimental measures of cooperation. These measures are based on the Public Good Games (PGG) conducted by Herrmann et al. (129). Students played PGGs first without and then with punishment for 10 rounds each. During both conditions and in all rounds, individuals stayed in the same group of four randomly allocated individuals. In each round of the PGG without punishment, an individual received an endowment of 20 units and could decide how much to keep for him/herself and how much to contribute to a public good. All contributions to the public good were multiplied by 1.6 and distributed equally among the four individuals. That is, from each token an individual invests, s/he gets back 0.4 tokens. Our first measure is initial contribution (in the first period only) of the PGG without punishment. This measure captures how individuals initially approach cooperation in a setting where people do not know each other. Our second measure is based on the PGG with punishment. In this condition, individuals received information in each period on the cooperative behavior of their group members and could subsequently set punishment points, at a cost to themselves (one punishment point would cost the punisher 1 unit, while it would deduct 3 units from the recipient). Our second measure is average contribution to the PGG (in percent of the endowment) over all 10 periods in the PGG with punishment.

This measure is based on a Schwarz human values question asked in the WVS. People rate on a six-point scale how much they believe the person described in the following sentence is like them: "It is important to this person to always behave properly; to avoid doing anything people would say is wrong". Since we do not want to capture cultural differences in closeness perceptions, we subtracted the mean answers a respondent gave to all human value questions from the respondent's answer to the creativity question following Schwarz's recommendation (193). We aggregated answers to the country level by taking the countries' means and standardized the variable at the country level.

Based on Gelfand et al. (133). Tightness captures the degree to which social norms are pervasive, clearly defined, and reliably imposed in a country. On a six-item Likert scale (ranging from strongly agree to strongly disagree) respondents rated six statements: " 1 . There are many social norms that people are supposed to abide by in this country. 2. In this country, there are very clear expectations for how people should act in most situations. 3. People agree upon what behaviors are appropriate versus inappropriate in most situations this country. 4. People in this country have a great deal of freedom in deciding how they want to behave in most situations. (Reverse coded) 5. In this country, if someone acts in an inappropriate way, others will strongly disapprove. 6. People in this country almost always comply with social norms." Data is available for 6,823 respondents across 33 countries.

This measure is based on a Schwarz human values question asked in the WVS. People rate on a six-point scale how much they believe the person described in the following sentence is like them: "Tradition is important to this person; to follow the customs handed down by one's religion or family". Since we do not want to capture cultural differences in closeness perceptions, we subtracted the mean answers a respondent gave to all human value questions from the respondent's answer to the creativity question following Schwarz's recommendation (193). We aggregated answers to the country level by taking the countries' means and standardized the variable at the country level. 

United Nations diplomats in New York City. Individuals have 30 days to pay a ticket before it goes into default, at which point an additional penalty is levied (generally $110 \%$ of the initial fine). Individuals then receive an additional 70 days to pay the ticket plus this penalty before it is recorded as an unpaid violation in the data set. Fisman and Miguel calculated the total number of unpaid diplomatic parking violations per diplomat for each country. The total period of coverage is November 24, 1997, to October 2002, when the State Department gave New York City permission to revoke the official diplomatic plates of vehicles with three or more outstanding unpaid violations. Before 2002, diplomats did not face sanctions when they failed to pay a parking tickets due to diplomatic immunity.

\section{S9.2. Country-level covariates}

Adherence to major religions:

Absolute latitude:

Caloric suitability:

Caloric suitability for oat:

Caloric suitability for rye:

Genetic heterogeneity

(ancestor adjusted):

Irrigation potential:
Taken from Barro and McCleary (186) for the year 2000. Retrieved on March 14 , 2016 from https://scholar.harvard.edu/barro/data sets. Adherents in a country to each of Catholicism, Protestantism, Orthodox Christianity, other Christian denominations, Islam, Hinduism and Buddhism, as fractions of the country's population.

Taken from Ashraf and Galor (165). The absolute latitude of a country's approximate geodesic centroid, as reported by the CIA's World Factbook.

Using data from Galor and Özak (171), the Caloric Suitability Index captures the average potential agricultural output (measured in calories) based on crops that were available for cultivation after $1500 \mathrm{CE}$. Caloric Suitability therefore captures the variation in potential crop yield across the globe, as accounted for by calories per hectare per year. The Caloric Suitability Index is constructed based on data from the Global AgroEcological Zones (GAEZ) project of the Food and Agriculture Organization (FAO). The GAEZ project supplies global estimates of crop yield for 48 crops in grids with cell sizes of 5-degree cells. We use the medium level rain-fed potential output.

Using data from Galor and Özak (171), the Caloric Suitability Index for oats captures the medium level rain-fed potential agricultural outputs (measured in calories) of oat.

Using data from Galor and Özak (171), the Caloric Suitability Index for rye captures the medium level rain-fed potential agricultural outputs (measured in calories) of rye.

Based on Ashraf and Galor (165). The expected heterozygosity (genetic diversity) of a country's population, predicted by migratory distances from East Africa (i.e., Addis Ababa, Ethiopia). It is a prediction based on the worldwide sample of 53 ethnic groups from the HGDP-CEPH Human Genome Diversity Cell Line Panel. The measure is ancestor adjusted using the World Migration Matrix, 1500-2000 CE, from Putterman and Weil (100).

Taken from Bentzen et al. (176). Irrigation potential measures the fraction of land that would have experienced at least a doubling of yields if irrigation were to be introduced into an area where agriculture was previously rainfed. The measure is in relation to all land suitable for agriculture. The measure is based on data from the global AgroEcological Zones (GAEZ) 2002 database of the Food and Agriculture Organization (FAO). 
Log GDP per capita:

Mean distance

to navigable waterways:

Parasite stress:

Ruggedness:

Timing of Neolithic Transformation (Ancestor adjusted):

Tropical area:
Real GDP per capita in 2000 CE, in international dollars (adjusted for Purchasing Power Parity), as reported by the Penn World Table, version 6.2. Natural logs are taken.

Taken from Gallup, Sachs and Mellinger (167). The distance, in thousands of km, from a GIS grid cell to the nearest ice-free coastline or sea-navigable river, averaged across the grid cells of a country. It is part of Harvard University's CID Research Datasets on General Measures of Geography.

The measure is Fincher and Thornhill (164)'s combined parasite-stress indicator (both non-zoonotic and zoonotic parasites). It is based on the GIDEON database (Global Infectious Disease \& Epidemiology Network; www.gideononline.com).

Taken from Nunn and Puga (166). It is based on (235). The terrain ruggedness index at one (grid-cell level) point is given by the square root of the sum of the squared differences in elevation between the central point and the eight adjacent points. Formally, it is defined as follows. Let $e_{r, c}$ denote elevation at the point located in row $r$ and column $\mathrm{c}$ of a grid of elevation points. Then the Terrain Ruggedness Index for this point is calculated as $\sqrt{\sum_{\mathrm{j}=\mathrm{c}-1}^{\mathrm{i}=\mathrm{c}+1} \sum_{\mathrm{i}=\mathrm{r}-1}^{\mathrm{i}+\mathrm{r}+1}\left(\mathrm{e}_{\mathrm{i}, \mathrm{j}}-\mathrm{e}_{\mathrm{r}, \mathrm{c}}\right)^{2}}$. The country-level indicator is the average across all the grid cells within a country.

The number of years elapsed, up to the year $2000 \mathrm{CE}$, since the majority of the population residing within a country's modern national borders began practicing sedentary agriculture as the primary mode of subsistence. This measure is based on Putterman (181). It is compiled using a wide variety of both region- and countryspecific archaeological studies as well as more general encyclopedic works on the transition from hunting and gathering to agriculture during the Neolithic Revolution. We use the ancestry adjusted indicator to take account for migration post $1500 \mathrm{CE}$. The ancestry weights are obtained from the World Migration Matrix of Putterman and Weil (100).

Taken from Nunn and Puga (166). It is based on Kottek et al. (236), who classify each cell on a 30 arc-minute grid covering the entire land area of the Earth into one of 31 climates in the widely used Köppen-Geiger climate classification (these categories are formed using temperature and precipitation data from the Climatic Research Unit of the University of East Anglia and the Global Precipitation Climatology Centre of the German Weather Service). Based on these data, Nunn and Puga (166) calculated the percentage of the land surface area of each country that has any of the four KöppenGeiger tropical climates.

\section{S9.3. Regional-level covariates}

All indicators are calculated for the ESS regions we use in Section S4 and the Italian provinces we use in Section S5.

Absolute latitude:

Absolute latitude of the centroid of a region. 
Caloric suitability:

Caloric suitability for oat:

Caloric suitability for rye:

Carolingian Empire:

Distance to the coast:

Elevation:

Lake or rivers (presence of):

Monastic presence (five indicators)

Roman roads:
Taken from Galor and Özak (171), the Caloric Suitability Index captures the average potential agricultural output (measured in calories) based on crops that were available for cultivation after $1500 \mathrm{CE}$. Caloric Suitability therefore captures the variation in potential crop yield across the globe, as accounted for by calories per hectare per year. The Caloric Suitability Index is constructed based on data from the Global AgroEcological Zones (GAEZ) project of the Food and Agriculture Organization (FAO). The GAEZ project supplies global estimates of crop yield for 48 crops in grids with cell sizes of 5-degree cells, which allowed us to construct regional indicators. We use the medium level rain-fed potential output.

Using data from Galor and Özak (171), the Caloric Suitability Index captures the medium level rain-fed potential agricultural outputs (measured in calories) of oat.

Using data from Galor and Özak (171), the Caloric Suitability Index captures the medium level rain-fed potential agricultural outputs (measured in calories) of rye.

Based on Shepherd's map (118), this variable indicates the areal fraction of a region that fell within the boundaries of the Carolingian Empire in the year $814 \mathrm{CE}$.

Distance of the centroid of a region from the coast, constructed based on a coastline physical vector map in $1: 10 \mathrm{~m}$ resolution. Source: Natural Earth (http://www.naturalearthdata.com/).

Mean elevation is constructed based on the global map (30 by 30 arcsecond cells) obtained from Global 30 Arc-Second Elevation data set. Source: GTOPO30 data set (https://lta.cr.usgs.gov/GTOPO30).

A dummy variable indicating whether there is a river or lake within a region. Rivers primarily derive from World Data Bank 2. Data of Europe primarily derives from Catchment Characterization and Modelling (CCM) Database 2.1 by the European Commission, Joint Research Centre, Institute for Environment and Sustainability. Data for North America derives the North American Environmental Atlas, a collaboration of government agencies in Canada, Mexico and the United States and the trilateral Commission for Environmental Cooperation (CEC). Source: Natural Earth (http://www.naturalearthdata.com/).

We created a monastic presence indicator for each of five different monastic orders: Cluniac, Cistercians, Premonstratensians, Franciscans, and Dominicans. For each indicator we drew $50 \mathrm{~km}$ radii around all the monastic houses of the corresponding order. Based on the pixels that fall within the $50 \mathrm{~km}$ radii we calculated for each indicator the percentage of each region that was exposed to the corresponding order at some point in time (for details regarding the pixels' size, see our description of how we constructed the regional Church exposure variable in Section S2). The underlying geolocated data on Cluniac (existing between before 998 to 1109 or later), Dominican (existing between 1216 to 1500), Franciscan (existing around 1300), and Premonstratensians Houses (existing between 1120 to 1500) are based on the Atlas zur Kirchengeschichte (222) and are taken from the Digital Atlas of Roman and Medieval Civilization (DARM, (223)). Cistercian Houses (existing between 1095 and 1675) are based on Donkin (224) and are taken from Andersen et al. (222). Unlike the Church exposure variable this indicator does not take the duration of exposure into account.

Using data from McCormick et. al. (237), this measure captures the length of Roman roads within a region (as identified in the Barrington Atlas) per area of the region. 
Ruggedness:

Socialist history:

Temperature:

Population density estimate in 500AD:

Precipitation:
The regional measure is constructed based on the global map (30 by 30 arc-second cells) obtained from the grid-cell-level data on ruggedness based on Nunn and Puga (166). For details, see the country-level indicator.

Indicator variable capturing whether a European region has a socialist history (see map in Figure S2.4). Regions that belonged to Yugoslavia are coded as having a socialist history, even though they were not part of the Warsaw pact. (This follows Churchill's original (1948) statement on the "Iron curtain".)

The means of the entire annual cycles of temperature is constructed for the period between 1901 and $2014 \mathrm{CE}$ based on monthly global maps ( 0.5 by 0.5 degree cells) obtained from the CRU-TS 3.1 Climate Database. Source: Harris et al. (2014).

Taken from Klein Goldewijk et al. $(116,117)$, this measures population density of a region in the year $500 \mathrm{CE}$. These estimates are based on the country estimates by McEvedy and Jones (226), broken down to the pixel level according to geographic factors that relate to the probability of settlement (e.g. proximity to waterways, temperature).

The means of the entire annual cycles of precipitation is constructed for the time period between 1901 and $2014 \mathrm{CE}$ based on monthly global maps ( 0.5 by 0.5 degree cells) obtained from the CRU-TS 3.1 Climate Database. Source: Harris et al. (238). 


\section{PART IV: REFERENCES}

1. M. Alvard, Genetic and cultural kinship among the Lamaleran whale hunters. Hum. Nat. 22, 89-107 (2011).

2. M. Alvard, Kinship and cooperation. Hum. Nat. 20, 394-416 (2009).

3. R. S. Walker et al., Living with Kin in Lowland Horticultural Societies. Curr. Anthropol. 54, 96-103 (2013).

4. R. S. Walker, K. R. Hill, Causes, consequences, and kin bias of human group fissions. Hum. Nat. 25, 465-475 (2014).

5. $\quad$ C. Lévi-Strauss, The elementary structures of kinship (Beacon Press, Boston, Rev., 1969).

6. J. Henrich, R. Boyd, P. J. Richerson, The puzzle of monogamous marriage. Philos. Trans. R. Soc. B Biol. Sci. 367, 657-669 (2012).

7. J. Henrich, The secret of our success: How culture is driving human evolution, domesticating our species, and making us smart (Princeton University Press, Princeton, 2016).

8. R. A. McNamara, J. Henrich, Kin and kinship psychology both influence cooperative coordination in Yasawa, Fiji. Evol. Hum. Behav. 38 (2017), doi:10.1016/j.evolhumbehav.2016.09.004.

9. H. S. Kaplan, P. L. Hooper, M. Gurven, The evolutionary and ecological roots of human social organization. Philos. Trans. R. Soc. Lond. B. Biol. Sci. 364, 3289-99 (2009).

10. P. Wiessner, Hunting, healing, and hxaro exchange - A long-term perspective on !Kung (Ju/'hoansi) large-game hunting. Evol. Hum. Behav. 23, 407-436 (2002).

11. P. Wiessner, On network analysis: The potential for understanding (and misunderstanding) !Kung Hxaro. Curr. Anthropol. 39, 514-517 (1998).

12. $\quad$ P. Wiessner, Kung San networks in a generational perspective. past Futur. (1986).

13. R. Fox, Kinship and marriage: an anthropological perspective (Penguin, Harmondsworth, 1967).

14. S. Bowles, J. K. Choi, Coevolution of farming and private property during the early Holocene. Proc. Natl. Acad. Sci. U. S. A. 110, 8830-8835 (2013).

15. L. Marshall, Marriage among !Kung bushmen. Africa (Lond). 29, 335-365 (1959).

16. K. R. Hill et al., Co-residence patterns in hunter-gatherer societies show unique human social structure. Science. 331, 1286-9 (2011).

17. G. P. Murdock, Social structure (Free Press, New York, 1949).

18. D. Jones, The Matrilocal Tribe. Hum. Nat. 22, 177-200 (2011).

19. A. W. Johnson, T. K. Earle, The evolution of human societies: from foraging group to agrarian state (Stanford University Press, 2000).

20. K. Flannery, J. Marcus, The creation of inequality: How our prehistoric ancestors set the stage for monarchy, slavery, and empire. 41, 631 (2012).

21. D. H. Bailey, K. R. Hill, R. S. Walker, Fitness consequences of spousal relatedness in 46 small-scale societies. Biol. Lett. 10, 2-5 (2014).

22. B. Chapais, Primeval kinship: How pair-bonding gave birth to human society (Harvard University Press, 2009).

23. R. S. Walker, D. H. Bailey, Marrying kin in small-scale societies. Am. J. Hum. Biol. 26, 384-388 (2014).

24. J. Henrich, S. J. Heine, A. Norenzayan, The weirdest people in the world? Behav. Brain Sci. 33, 61-83 (2010).

25. J. Goody, The development of the family and marriage in Europe (Cambridge University Press, 1983).

26. D. M. Schneider, G. C. Homans, Kinship Terminology and the American Kinship System. Am. Anthropol. 57, 1194-1208 (1955).

27. M. Strathern, After nature : English kinship in the late twentieth century (Cambridge University Press, Cambridge England; New York, 1992).

28. J. Yellen, Hunter-gatherer populations and archaeological inference. World Archaeol. 4, 244-253 (1972).

29. F. Fukuyama, The origins of political order: From prehuman times to the French Revolution (Farrar, Straus and Giroux, New York, ed. 1st, 2011).

30. J. M. Diamond, Guns, germs, and steel: the fates of human societies (W.W. Norton \& Co, 1997).

31. G. P. Murdock, Ethnographic Atlas, installments i-xxvii. Ethnology, 1-10.

32. D. Bondarenko, A. Kazankov, D. Khaltourina, A. Korotayev, Ethnographic Atlas xxxi: peoples of easternmost Europe. Ethnology. 44, 261-289 (2005).

33. H. Barry, Ethnographic Atlas xxviii. Ethnology. 19, 245-263 (1980).

34. J. P. Gray, A corrected Ethnographic Atlas. World Cult. 10, $24-85$ (1999).

35. A. Korotayev, A. Kazankov, S. Borinskaya, D. Khaltourina, D. Bondarenko, Ethnographic Atlas xxx: peoples of 
Siberia. Ethnology. 43, 83-92 (2004).

36. K. R. Kirby et al., D-PLACE: A global database of cultural, linguistic and environmental diversity, 1-14 (2016).

37. W. D. Hamilton, The genetical evolution of social behaviour. I. J. Theor. Biol. 7, 1-16 (1964).

38. N. Henrich, J. Henrich, Why Humans cooperate: a cultural and evolutionary explanation (Oxford University Press, New York, 2007).

39. B. Enke, Kinship systems, cooperation and the evolution of culture. Dec 5 (2017).

40. L. H. Morgan, Systems of consanguinity and affinity of the human family (University of Nebraska Press, Lincoln and London, 1870).

41. C. Kemp, T. Regier, Kinship categories across languages reflect general communicative principles. Science (80-. ). 336, 1049-1054 (2012).

42. L. Betzig, Means, variances, and ranges in reproductive success: comparative evidence. Evol. Hum. Behav. 33, 309-317 (2012).

43. J. Henrich, R. Boyd, How evolved psychological mechanisms empower cultural group selection. Behav. Brain Sci. 39 (2016), doi:10.1017/S0140525X15000138.

44. P. Giuliano, N. Nunn, Ancestral characteristics of modern populations. Econ. Hist. Dev. Reg. 33, 1-17 (2018).

45. A. H. Bittles, "A background summary of consanguineous marriage" (2001).

46. A. H. Bittles, The bases of western attitudes to consanguineous marriage. Dev. Med. Child Neurol. 45, 135-138 (2003).

47. A. H. Bittles, M. L. Black, Consanguinity, human evolution, and complex diseases. Proc. Natl. Acad. Sci. 107, 1779-1786 (2010).

48. T. J. Pemberton, N. A. Rosenberg, Population-genetic influences on genomic estimates of the inbreeding coefficient: A global perspective. Hum. Hered. 77, 37-48 (2014).

49. L. A. Vassallo, Studies on Maltese consanguinity. Malta Med. J. 15, 37-38 (2003).

50. N. Freire-Maia, Inbreeding levels in different countries. Eugen. Q. 4 (1957).

51. K. Ubl, Inzestverbot und Gesetzgebung. Die Konstruktion eines Verbrechens (300-1100) (Walter de Gruyter, Berlin, 2008).

52. C. Donahue, Law, marriage, and society in the Later Middle Ages: arguments about marriage in five courts (Cambridge University Press, Cambridge, 2008).

53. J. Pinto-Cisternas, G. Zei, A. Moroni, Consanguinity in Spain, 1911-1943: general methodology, behavior of demographic variables, and regional differences. Soc. Biol. 26, 55-71 (1979).

54. L. L. Cavalli-Sforza, A. Moroni, G. Zei, Consanguinity, inbreeding, and genetic drift in Italy (Princeton University Press, New Jersey, 2004).

55. J. Sutter, T. Léon, Fréquence et répartition des mariages consanguins en France. Popul. (French Ed. 3, 607-630 (1948).

56. J. Sutter, J.-M. Goux, Decline of consanguineous marriages in France from 1926 to 1958. Eugen. Q. 11, 127-140 (1964).

57. A. Macfarlane, The origins of English individualism: the family, property and social transition (Blackwell, Oxford, 1978).

58. G. Clark, A farewell to alms (Princeton University Press, Princeton, N.J, 2007).

59. P. Laslett, The world we have lost: further explored (Scribner, New York, ed. 3rd, 1984).

60. E. Todd, Explanation of ideology: Family structure and social system (Blackwell, 1985).

61. D. D'Avray, Review article: Kinship and religion in the early Middle Ages. Early Mediev. Eur. 20, $195-212$ (2012).

62. J. L. van Zanden, T. de Moor, Girl power: the European marriage pattern and labour markets in the North Sea region in the late medieval and early modern period 1. 1, 1-33 (2010).

63. D. Herlihy, Medieval households (Harvard University Press, Cambridge, Mass., 1985).

64. J. Hajnal, Two Kinds of Preindustiral Household Formation System. Popul. Dev. Rev. 8, 449-494 (1982).

65. S. Carmichael, A. Rijpma, Blood is thicker than water. Cross-Cultural Res. (2017), doi:10.1177/1069397117691025.

66. M. Mitterauer, in Populations, connections, droits fondamentaux: mélanges pour Jean-Paul Lehners, T.

Kolnberger, N. Franz, P. Péporté, Eds. (Mandelbaum Verlag, 2015), pp. 37-60.

67. M. Mitterauer, Kontrastierende Heiratsregeln: Traditionen des Orients und Europas im interkulturellen Vergleich. Hist. Sozialkd. 41, 4-16 (2011).

68. M. Mitterauer, G. Chapple, Why Europe?: the medieval origins of its special path (University of Chicago Press, Chicago, 2010).

69. J. Goody, The European family (Wiley-Blackwell, Oxford, 2000). 
70. J. Goody, The oriental, the ancient and the primitive (Cambridge, 1990).

71. A. Greif, Family structure, institutions, and growth: The origins and implications of western corporations. Am. Econ. Rev. 96, 308-312 (2006).

72. A. Greif, G. Tabellini, Cultural and institutional bifurcation: China and Europe compared. Am. Econ. Rev. 100, $135-140$ (2010).

73. A. Norenzayan et al., The Cultural evolution of Prosocial Religions. Behav. Brain Sci. 39, 1-86 (2016).

74. W. H. McNeil, The Rise of the West: A History of the Human Community (University of Chicago Press, Chicago, 1991).

75. C. E. G. Amorim et al., Understanding 6th-century Barbarian social organization and migration through Paleogenomics. bioRxiv, 268250 (2018).

76. M. Mitterauer, Why Europe?: the medieval origins of its special path (University of Chicago Press, Chicago, 2010).

77. R. M. Karras, Concubinage and slavery in the Viking age. Scand. Stud. 62, 141-162 (1990).

78. J. Witte, The Western case for monogamy over polygamy (Cambridge University Press, Cambridge, UK, 2015).

79. G. Ausenda, in The Visigoths from the migration period to the seventh century: an ethnographic perspective, $\mathrm{P}$. Heather, Ed. (The Boydell Press, Woodbridge, 1999), pp. 129-190.

80. M. C. Ross, Concubinage in Anglo-Saxon England. Past Present, 3-34 (1985).

81. R. T. Anderson, Changing kinship in Europe (University of California, Berkeley, 1956).

82. H. J. Berman, Law and revolution: the formation of the Western legal tradition (Harvard University Press, Cambridge, Mass., 1983).

83. T. M. Charles-Edwards, Kinship, status and the origins of the hide. Past Present, 3-33 (1972).

84. A. Greif, Institutions and the path to the modern economy: Lessons from medieval trade (Cambridge University Press, New York, 2006).

85. P. J. Heather, The Visigoths from the migration period to the seventh century: an ethnographic perspective (Boydell Press, Woodbridge, 1999).

86. J. Gaudemet, Du droit Romain tardif aux conciles Merovingiens: les condamnations de l'inceste. Zeitschrift der Savigny-Stiftung fuer Rechtsgeschichte. 82, 369-379 (1996).

87. W. E. Addis, A catholic dictionary (Aeterna Press, 1961).

88. W. Smith, S. Cheetham, A dictionary of Christian antiquities: being a continuation of the dictionary of the Bible (Murray, London, Volume 1., 1875).

89. F. Gavin, Pastoral care in marriage preparation (Can. 1063): history, analysis of the norm and its implementation by some particular Churches (Gregorian University Press, Rome, 2004).

90. M. M. Sheehan, Marriage, family, and law in Medieval Europe: collected studies (University of Toronto Press, Toronto, 1996).

91. C. Rolker, in Law and marriage in medieval and early modern times: proceedings of the Eight Carlsberg Academy Conference on Medieval Legal History 2011, P. Andersen, K. Salonen, H. Møller Sigh, H. Vogt, Eds. (Copenhagen, 2012), pp. 145-165.

92. M. de Jong, in From Sappho to De Sade: Moments in the History of Sexuality, J. N. Bremmer, Ed. (Routledge, London, 1989), pp. 36-59.

93. Augustine, The city of god against the pagans (Cambridge., 1998).

94. A. Greif, J. Rubin, "Political legitimacy and the institutional foundations of limited government" (2018).

95. R. B. Ekelund, R. Hebert, R. D. Tollison, G. M. Anderson, A. B. Davidson, Sacred trust: the medieval church as an economic firm (Oxford University Press, New York, 1996).

96. P. Brown, Through the eye of a needle: wealth, the fall of Rome, and the making of Christianity in the West, 350-550 AD (Princeton University Press, 2012).

97. J. Henrich, W.E.I.R.D. People: How Westerners became individualistic, self-obsessed, guilt-ridden, analytic, patient, principled and prosperious (Princeton University Press, Princeton).

98. J. F. Schulz, "Why Europe? The Church, Kin-Networks and Institutional Development (Nov)" (2017).

99. A. Greif, G. Tabellini, The clan and the city: Sustaining cooperation in China and Europe. J. Comp. Econ. 45, 135 (2015).

100. L. Putterman, D. N. Weil, Post-1500 population flows and the long run determinants of economic growth and inequality. Quaterly J. Econ. 125, 1627-1682 (2010).

101. J. V. A. Fine, The late medieval Balkans: a critical survey from the late twelfth century to the Ottoman conquest (University of Michigan Press, Ann Arbor, 1987).

102. N. Blomkvist, S. Brink, T. Lindkvist, in Christianization and the Rise of Christian Monarchy: Scandinavia, Central Europe and Rus' c. 900-1200, N. Berend, Ed. (Cambridge University Press, Cambridge, UK, 2007). 
103. E. Archibald, Incest and the medieval imagination (Clarendon Press, Oxford, 2001).

104. G. of Wales, The journey through Wales and the description of Wales (Penguin books, Hammondsworth).

105. S. P. Ramet, Nihil obstat: religion, politics, and social change in East-Central Europe and Russia (Duke University Press, Durham \& London, 1998).

106. M. Burgees, The Eastern Orthodox Church: concise histories with chronological checklists of their primates (2010).

107. A. Poppe, Christian Russia in the making (Ashgate Publishing Limited, Hampshire, 2007).

108. O. Zinkewych, A. Sorokowski, A thousand years of Christianity in Ukraine: an encyclopedic chronology (Smoloskyp Publishers, New York, 1988).

109. J. F. Harrington, Reordering marriage and society in reformation Germany (Cambridge University Press, Cambridge, 1995).

110. B. Sawyer, P. Sawyer, Medieval Scandinavia: from conversion to reformation circa 800-1500 (University of Minnesota Press, Minneapolis, 1993).

111. J. Hubert, K. S. Latourette, J. Martin, Atlas zur Kirchengeschichte, die Christlischen Kirchen in Geschichte und Gegenwart (Herder, Freiburg, 1980).

112. V. Ramseyer, The transformation of a religious landscape: medieval southern Italy 850-1150 (Cornell University Press, Ithaca and London, 2006).

113. C. Wickham, Early medieval Italy: Central power and local society 400-1000 (University of Michigan Press, 1981).

114. M. Betti, in Imperial spheres and the Adriatic: Byzantium, the Carolingians and the Treaty of Aachen (812), M. Ančić, J. Shepard, T. Vedriš, Eds. (New York, 2018), p. 333.

115. K. L. Reyerson, in The New Cambridge Medieval History V, D. Abulafia, Ed. (Cambridge University Press, 1999), pp. 50-70.

116. K. K. Goldewijk, A. Beusen, G. Van Drecht, The HYDE 3.1 spatially explicit database of human-induced global land-use change over the past 12,000 years. Glob. Ecol. Biogeogr. 20, 73-86 (2010).

117. K. K. Goldewijk, A. Beusen, P. Janssen, Long-term dynamic modeling of global population and built-up area in a spatially explicit way : HYDE 3 . 1 (2010), doi:10.1177/0959683609356587.

118. W. Shepherd, Historical atlas (Henry Holt and Company, New York, 1911).

119. D. Acemoglu, J. Robinson, Why nations fail: the origins of power, prosperity, and poverty (Random House Digital, Inc., 2012).

120. R. Bond, P. B. Smith, Culture and conformity: a meta-analysis of studies using Asch's (1952b, 1956) line judgement task. Psychol. Bull. 119, 111-137 (1996).

121. J. Haidt, J. Graham, When morality opposes justice: Conservatives have moral intuitions that liberals may not recognize. Soc. Justice Res. 20, 98-116 (2007).

122. T. Talhelm et al., Large-scale psychological differences within China explained by rice versus wheat agriculture. Science. 344, 603-608 (2014).

123. A. K. Uskul, S. Kitayama, R. E. Nisbett, Ecocultural basis of cognition: Farmers and fishermen are more holistic than herders (vol 105, pg 8552, 2008). Proc. Natl. Acad. Sci. U. S. A. 105, 8552-6 (2008).

124. M. Schaller, D. R. Murray, Pathogens, personality, and culture: Disease prevalence predicts worldwide variability in sociosexuality, extraversion, and openness to experience. J. Pers. Soc. Psychol. 95, 212-221 (2008).

125. S. M. Adams et al., The genetic legacy of religious diversity and intolerance: paternal lineages of Christians, Jews, and Muslims in the Iberian Peninsula. Am. J. Hum. Genet. 83, 725-736 (2008).

126. A. Falk et al., Global evidence on economic preferences. Q. J. Econ. (2018).

127. A. Trompenaars, C. Hampden-Turner, Riding the waves of culture: understanding cultural diversity in global business (McGraw Hill, New York; London, ed. 2nd, 1998).

128. S. Gächter, J. F. Schulz, Intrinsic honesty and the prevalence of rule violations across societies. Nature. 531, 111 (2016).

129. B. Herrmann, C. Thöni, S. Gächter, Antisocial punishment across societies. Science. 319, 1362-1367 (2008).

130. S. Kitayama, H. Park, A. T. Sevincer, M. Karasawa, A. K. Uskul, A cultural task analysis of implicit independence: comparing North America, Western Europe, and East Asia. J. Pers. Soc. Psychol. 97, 236-55 (2009).

131. C. Kanagawa, S. E. Cross, H. R. Markus, "Who Am I?" The Cultural Psychology of the Conceptual Self. Personal. Soc. Psychol. Bull. 27, 90-103 (2001).

132. K. R. Scherer, H. G. Wallbott, Evidence for universality and cultural variation of differential emotion response patterning. J. Personal. Soc. Psychol. 66, 310-328. 
133. M. J. Gelfand et al., Differences between tight and loose cultures: a 33-nation study. Science. 332, 1100-1104 (2011).

134. A. Alesina, P. Giuliano, Family ties and political participation. J. Eur. Econ. Assoc. 9, 817-839 (2011).

135. A. Alesina, P. Giuliano, The power of the family. J. Econ. Growth. 15, 93-125 (2010).

136. A. Alesina, P. Giuliano, in Handbook of Economic Growth (2014), vol. 2, pp. 177-215.

137. N. J. Wen, J. M. Clegg, C. H. Legare, Smart conformists: Children and adolescents associate conformity with intelligence across cultures. Child Dev. 00, 1-13 (2017).

138. L. R. Binford, Constructing frames of reference: an analytical method for archaeological theory building using ethnographic and environmental data sets. Univ. California, Berkeley (2001).

139. S. Kitayama, K. Ishii, T. Imada, K. Takemura, J. Ramaswamy, Voluntary settlement and the spirit of independence: evidence from Japan's “Northern frontier”. J. Pers. Soc. Psychol. 91, 369-384 (2006).

140. S. Kitayama, J. Park, Cultural neuroscience of the self: understanding the social grounding of the brain. Soc. Cogn. Affect. Neurosci. 5, 111-129 (2010).

141. J. Henrich, Culture and social behavior (McGraw-Hill, New York, 1994).

142. Y. Miyamoto, R. E. Nisbett, T. Masuda, Culture and the physical environment: Holistic versus analytic perceptual affordances. Psychol. Sci. 17, 113-119 (2006).

143. S. G. Goto, Y. Ando, C. Huang, A. Yee, R. S. Lewis, Cultural differences in the visual processing of meaning: detecting incongruities between background and foreground objects using the N400. Soc. Cogn. Affect. Neurosci. 5, 242-53 (2010).

144. T. Masuda, R. E. Nisbett, Attending holistically versus analytically: Comparing the context sensitivity of Japanese and Americans. J. Pers. Soc. Psychol. 81 (2001).

145. H. Witkin, J. Berry, Psychological differentiation in cross-cultural perspective. J. Cross. Cult. Psychol. (1975).

146. J. M. Clegg, N. J. Wen, C. H. Legare, Is non-conformity WEIRD? Cultural variation in adults' beliefs about children's competency and conformity. J. Exp. Psychol. Gen. 146, 428-441 (2017).

147. S. C. Levinson, Kinship and human thought. Science (80-. ). 336, 988-989 (2012).

148. M. Segall, D. Campbell, M. J. Herskovits, The influence of culture on visual perception (The Bobbs-Merrill Company, New York, 1966).

149. J. Henrich et al., Markets, religion, community size, and the evolution of fairness and punishment. Science. 327, 1480-1484 (2010).

150. R. E. Nisbett, The geography of thought: How Asians and Westerners think differently...and why (The Free Press, New York, 2003).

151. R. E. Nisbett, I. Choi, K. Peng, A. Norenzayan, Culture and systems of thought: Holistic versus analytic cognition. Psychol. Rev. 108, 291-310 (2001).

152. B. R. House et al., Ontogeny of prosocial behavior across diverse societies. Proc. Natl. Acad. Sci. 110, 1458614591 (2013).

153. S. Oishi, T. Talhelm, Residential Mobility: What Psychological Research Reveals. Curr. Dir. Psychol. Sci. 21, 425-430 (2012).

154. S. Oishi, J. Schug, M. Yuki, J. Axt, in Handbook of Advances in Culture and Psychology (Oxford University, New York, Kindle Edi., 2015), vol. 5, pp. 221-272.

155. P. R. Blake et al., The ontogeny of fairness in seven societies. Nature, 1-5 (2015).

156. K. McAuliffe, P. R. Blake, N. Steinbeis, F. Warneken, The developmental foundations of human fairness. Nat. Hum. Behav. 1, 0042 (2017).

157. P. Giuliano, Living arrangements in Western Europe: does cultural origin matter? J. Eur. Econ. Assoc. 5, 927952 (2007).

158. R. Fernández, Women, work, and culture. J. Eur. Econ. Assoc. 5, 61-79 (2007).

159. A. Alesina, P. Giuliano, N. Nunn, On the Origins of Gender Roles: Women and the Plough. Q. J. Econ. 128, 469-530 (2013).

160. E. Van de Vliert, Climato-economic origins of variation in ingroup favoritism. J. Cross. Cult. Psychol. 42, $494-$ 515 (2011).

161. E. Van de Vliert, Climato-economic habitats support patterns of human needs, stresses, and freedoms. Behav. Brain Sci. 36, 465-480 (2013).

162. J. C. Buggle, "Growing collectivism: irrigation, group conformity and technological divergence" (2017).

163. C. L. Fincher, R. Thornhill, D. R. Murray, M. Schaller, Pathogen prevalence predicts human cross-cultural variability in individualism/collectivism. Proc. Biol. Sci. 275, 1279-85 (2008).

164. C. L. Fincher, R. Thornhill, Parasite-stress promotes in-group assortative sociality: the cases of strong family ties and heightened religiosity. Behav. brain siences. 35, 61-119 (2012). 
165. Q. Ashraf, O. Galor, The "Out of Africa" hypothesis, human genetic diversity, and comparative economic development. Am. Econ. Rev. 103, 1-46 (2013).

166. N. Nunn, D. Puga, Ruggedness: the blessing of bad geography in Africa. Rev. Econ. Stat. 94, 20-36 (2012).

167. J. L. Gallup, J. D. Sachs, A. D. Mellinger, Geography and economic development. Int. Reg. Sci. Rev. 22, 179232 (1999).

168. J. Henrich et al., In search of Homo economicus: behavioral experiments in 15 small-scale societies. Am. Econ. Rev. (Papers Proceedings). 91, 73-84 (2001).

169. J. Henrich et al., "Economic man" in cross-cultural perspective: behavioral experiments in 15 small-scale societies. Behav. Brain Sci. 28, 795-855 (2005).

170. J. Henrich et al., Costly punishment across human societies. Science. 312, 1767-1770 (2006).

171. O. Galor, Ö. Özak, The agricultural origins of time preference. Am. Econ. Rev. 10, 3064-3103 (2016).

172. A. D. Hoben, A. P. Buunk, C. L. Fincher, R. Thornhill, M. Schaller, On the adaptive origins and maladaptive consequences of human inbreeding: Parasite prevalence, immune functioning, and consanguineous marriage. Evol. Psychol. 8, 658-676 (2010).

173. D. J. Hruschka et al., Impartial institutions, pathogen stress and the expanding social network. Hum. Nat. 25, 567-579 (2014).

174. D. J. Hruschka, J. Henrich, Institutions, parasites and the persistence of in-group preferences. PLoS One. 8 (2013), doi:10.1371/journal.pone.0063642.

175. J. D. Angrist, J.-S. Pischke, Mostly harmless econometrics: an empiricist's companion (Princeton University Press, Princeton, 2008).

176. J. S. Bentzen, N. Kaarsen, A. M. Wingender, Irrigation and autocracy. J. Eur. Econ. Assoc. 15, 1-53 (2017).

177. M. Mann, The sources of social power: a history of social power from the beginning to AD 1760 (Cambridge University Press, Cambridge, Vol. 1., 1986).

178. K. A. Wittfogel, Oriental despotism: a comparative study of total power (Yale University Press, New Haven, 1957).

179. T. B. Andersen, P. S. Jensen, C. V. Skovsgaard, The heavy plow and the agricultural revolution in Medieval Europe. J. Dev. Econ. 118, 133-149 (2016).

180. L. White, Medieval technology and social change (Oxford University Press, Oxford, 1962).

181. L. Putterman, Agriculture, diffusion and development: ripple effects of the neolithic revolution. Economica. 75, 729-748 (2008).

182. Q. Ashraf, O. Galor, M. Klemp, "The out of Africa hypothesis of comparative development reflected by nighttime light intensity" (2014).

183. O. Galor, M. Klemp, "Roots of autocracy" (2015).

184. C. E. Arbatli, Q. Ashraf, O. Galor, "The nature of conflict" (5486, 2015), doi:10.1177/106591295100400201.

185. Q. Ashraf, O. Galor, Genetic diversity and the origins of cultural fragmentation. Am. Econ. Rev. 103, 528-533 (2013).

186. R. J. Barro, R. M. McCleary, Religion and economic growth across countries. Am. Sociol. Rev. 68, 760-781 (2003).

187. P. Norris, R. Inglehart, Sacred and Secular: Religion and Politics Worldwide (Cambridge University Press, Cambridge, 2 edition., 2012).

188. T. G. Conley, GMM estimation with cross-sectional dependence. J. Econom. 92, 1-45 (1999).

189. G. Hofstede, Culture's consequences: comparing values, behaviors, institutions and organizations across nations (SAGE Publications, London, 2003).

190. E. S. Kashima, Culture and language: the case of cultural dimensions and personal pronoun use. J. Cross. Cult. Psychol. 29, 461-486 (2012).

191. M. Meyer-schwarzenberger, thesis, St.Gallen (2015).

192. G. Tabellini, Institutions and Culture. J. Eur. Econ. Assoc. 6, 255-294 (2008).

193. S. H. Schwartz, An overview of the Schwartz theory of basic values. Online Readings Psychol. Cult. 2, 1-20 (2012).

194. L. J. Ji, Z. Zhang, R. E. Nisbett, Is it culture or is it language? Examination of language effects in cross-cultural research on categorization. J. Pers. Soc. Psychol. 87, 57-65 (2004).

195. T. Talhelm, J. Graham, J. Haidt, "The budding collectivism revolution." (Cambridge, MA, 2017).

196. M. Varnum, I. Grossmann, S. Kitayama, R. E. Nisbett, "The origin of cultural differences in cognition: the social orientation hypothesis" (University of Michigan, Ann Arbor, 2008).

197. A. Hajikhameneh, E. O. Kimbrough, Individualism, collectivism, and trade. Exp. Econ., 1-31 (2017).

198. M. E. W. Varnum, I. Grossmann, S. Kitayama, R. E. Nisbett, The origin of cultural differences in cognition: 
Evidence for the social orientation hypothesis. Curr. Dir. Psychol. Sci. 19, 9-13 (2010).

199. S. E. Asch, Effects of group pressure on the modification and distortion of judgments (1951).

200. S. E. Asch, Social psycholgy (Holt, New York, 1952).

201. S. E. Asch, Studies of independence and conformity: 1.A minority of one against a unamious majority. Psychol. Monogr. 70 (1956).

202. G. Tabellini, Culture and institutions: Economic development in the regions of Europe. J. Eur. Econ. Assoc. 8, 677-716 (2010).

203. U. Fischbacher, F. Föllmi-Heusi, Lies in disguise - an experimental study on cheating. J. Eur. Econ. Assoc. 11, 525-547 (2013).

204. R. Fisman, E. Miguel, Corruption, norms, and legal enforcement: evidence from diplomatic parking tickets. $J$. Polit. Econ. 115, 1020-1048 (2007).

205. C. Hampden-Turner, F. Trompenaars, Building Cross-cultural Competence: Howe to Create Wealth from Conflicting Values (Yale University Press, New Haven, 2000).

206. U. Fischbacher, S. Gächter, Heterogeneous social preferences and the dynamics of free riding in public goods experiments. Amercian Econ. Rev., 541-556 (2010).

207. M. Chudek, J. Henrich, Culture-gene coevolution, norm-psychology and the emergence of human prosociality. Trends Cogn. Sci. 15, 218-226 (2011).

208. E. Fehr, S. Gächter, Altruistic punishment in humans. Nature. 415, 137-140 (2002).

209. C. Thöni, in Social dilemmas: New perspectives on trust (2016), pp. 1-19.

210. C. Thöni, J.-R. Tyran, E. Wengström, Microfoundations of social capital. J. Public Econ. 96, 635-643 (2012).

211. E. Spolaore, R. Wacziarg, in The Palgrave Handbook of Economics of Languages, V. Ginsburgh, S. Weber, Eds. (Palgrave Macmillan, London, 2016).

212. M. Muthukrishna et al., A WEIRD scale of cultural distance (9999).

213. E. Spolaore, R. Wacziarg, Ancestry and development: new evidence (2017).

214. Y. Algan, P. Cahuc, Trust and growth. Annu. Rev. Econom. 5, 521-549 (2013).

215. Y. Algan, P. Cahuc, Inherited trust and growth. Am. Econ. Rev. 100, 2060-2092 (2010).

216. S. Knack, P. Keefer, Does Social Capital Have an Economic Payoff? Q. J. Econ. 112, 1251-1288 (1997).

217. M. Akbari, D. Bahrami-Rad, E. O. Kimbrough, "Kinship, fractionalization and corruption," SSRN (2847222, 2016).

218. M. A. Woodley, E. Bell, Consanguinity as a Major Predictor of Levels of Democracy: A Study of 70 Nations. $J$. Cross. Cult. Psychol. 44, 263-280 (2012).

219. D. de la Croix, M. Doepke, J. Mokyr, Clans, guilds, and markets: apprenticeship institutions and growth in the preindustrial economy. Q. J. Econ. 133, 1-70 (2018).

220. A. V. Korotayev, Unilineal descent organization and deep Christianization: a cross-cultural comparison. CrossCultural Res. 37, 133-157 (2003).

221. S. H. Schwartz, in Measuring attitudes cross-nationally - lessons from the European Social Survey, R. Jowell, C. Roberts, R. Fitzgerald, G. Eva, Eds. (Sage, London, 2006), pp. 169-203.

222. T. B. Andersen, J. Bentzen, C. J. Dalgaard, P. Sharp, Pre-reformation roots of the protestant ethic. Econ. J. 127, 1756-1793 (2017).

223. M. McCormick, E. Al, The Digital Atlas of Roman and Medieval Civilizations.

224. R. Donkin, The Cistercians: Studies in the Geography of Medieval England and Wales (Pontifical Institute of Medieval Studies, Toronto, 1978).

225. H. Kleinschmidt, Understanding the Middle Ages (Boydell Press, Woodbridge, UK, 2000).

226. C. McEvedy, R. Jones, Atlas of world population history (Penguin, New York, 1978).

227. L. Guiso, P. Sapienza, L. Zingales, Long-term persistence. J. Eur. Econ. Assoc. 14, 1401-1436 (2016).

228. S. M. Adams et al., The Genetic Legacy of Religious Diversity and Intolerance: Paternal Lineages of Christians, Jews, and Muslims in the Iberian Peninsula. Am. J. Hum. Genet. (2008), doi:10.1016/j.ajhg.2008.11.007.

229. L. Guiso, P. Spanienza, L. Zingales, The role of social capital in financial development. Am. Econ. Rev. 94, 526556 (2004).

230. R. C. Cameron, D. L. Miller, A practitioner's guide to cluster-robust inference. J. Hum. Resour. 50, 317-372 (2015).

231. O. Galor, M. Zak, A. Sarid, Geographical origins and economic consequences of language structures. SSRN Electron. J. (2017), doi:10.2139/ssrn.2820889.

232. D. Kistler, C. Thöni, C. Welzel, Survey response and observed behavior: emancipative and secular values predict prosocial behaviors. J. Cross. Cult. Psychol. 48, 461-489 (2017).

233. H. Hammarström, S. Bank, R. Forkel, M. Haspelmath, Glottolog 2.7. Max Planck Inst. Sci. Hum. Hist. (2016). 
234. CIESIN, Gridded Population of the World, Version 4 (GPWv4) (2016).

235. S. J. Riley, S. D. DeGloria, R. Elliot, A terrain ruggedness index that quantifies topographic heterogeneity. Intermt. J. Sci. 5, 23-27 (1999).

236. M. Kottek, J. Grieser, C. Beck, B. Rudolf, F. Rubel, World map of the Köppen-Geiger climate classification updated. Meteorol. Zeitschrift. 15, 259-263 (2006).

237. M. McCormick, G. Huang, G. Zambotti, J. Lavash, Roman road network (version 2008). hdl1902.1/22610, Harvard Dataverse, V1 (2013).

238. I. Harris, P. D. Jones, T. J. Osborn, D. H. Lister, Updated high-resolution grids of monthly climatic observations - the CRU TS3.10 dataset. Int. J. Climatol. (2013), doi:10.1002/joc.3711.

239. T. Ware, The Orthodox Church: an introduction to Eastern Christianity (Books, Penguin, London, ed. 3rd, 2015).

240. J. V. A. Fine, The early medieval Balkans: a critical survey from the sixth to the late twelfth century (University of Michigan Press, Ann Arbor, 1983).

241. D. E. R. Watt, Die Konzilien in Schottland bis zur Reformation (Ferdinand Schoeningh, Paderborn, 2001).

242. G. A. Loud, The Latin Church in Norman Italy (Cambridge University Press, Cambridge, UK, 2007). 